\title{
Measurement in a Wind Tunnel of the Modification of Mean Wind and Turbulence Characteristics Due to Induction Effects Near Wind Turbine Rotors
}

D. E. Neff R. N. Meroney

Colorado State University

J. R. Connell, PNL Program Manager

August 1987

Prepared by Colorado State University for Pacific Northwest Laboratory under Contract DE-AC06-76RLO 1830 with the U.S. Department of Energy

Pacific Northwest Laboratory Operated for the U.S. Department of Energy by Battelle Memorial Institute 


\title{
DISCLAIMER
}

This report was prepared as an account of work sponsored by an agency of the United States Government. Neither the United States Government nor any agency thereof, nor Battelle Memorial Institute, nor any of their employees, makes any warranty, expressed or implied, or assumes any legal liability or responsibility for the accuracy, completeness, or usefulness of any information, apparatus, product, or process disclosed, or represents that its use would not infringe privately owned rights. Reference herein to any specific commercial product, process, or service by trade name, trademark, manufacturer, or otherwise, does not necessarily constitute or imply its endorsement, recommendation, or favoring by the United States Government of any agency thereof, or Battelle Memorial Institute. The views and opinions of authors expressed herein do not necessarly state or reflect those of the United States Government or any agency thereof, or Battelle Memorial Institute.

\author{
PACIFIC NORTHWEST LABORATORY \\ operated by \\ BATTELLE MEMORIAL INSTITUTE \\ for the \\ UNITED STATES DEPARTMENT OF ENERGY \\ under Contract DE-AC06-76RLO 1830
}

\begin{tabular}{|c|c|}
\hline \multicolumn{2}{|c|}{$\begin{array}{c}\text { Printed in the United States of America } \\
\text { Available from } \\
\text { National Technical Information Service } \\
\text { United States Department of Commerce } \\
5285 \text { Port Royal Road } \\
\text { Springfield, Virginia } 22161\end{array}$} \\
\hline \multicolumn{2}{|c|}{$\begin{array}{l}\text { NTIS Price Codes } \\
\text { Microfiche A01 }\end{array}$} \\
\hline \multicolumn{2}{|c|}{ Printed Copy } \\
\hline Pages & $\begin{array}{l}\text { Price } \\
\text { Codes }\end{array}$ \\
\hline $001-025$ & A02 \\
\hline $026-050$ & $\mathrm{~A} 03$ \\
\hline $051-075$ & $\mathrm{~A} 04$ \\
\hline $076-100$ & $\mathrm{~A} 05$ \\
\hline $101-125$ & A06 \\
\hline $126-150$ & A07 \\
\hline $151-175$ & $A 08$ \\
\hline $176-200$ & $\mathrm{~A} 09$ \\
\hline $201-225$ & A010 \\
\hline $226-250$ & A011 \\
\hline $251-275$ & A012 \\
\hline $276-300$ & A013 \\
\hline
\end{tabular}


MEASUREMENT IN A WIND TUNNEL OF THE MODIFICATION OF MEAN WIND AND TURBULENCE CHARACTERISTICS DUE TO INDUCTION EFFECTS NEAR WIND TURBINE ROTORS

D. E. Neff

R. N. Meroney

Fluid Mechanics and Wind Engineering Program Department of Civil Engineering

Colorado State University

Fort Collins, Co 80523

J. R. Conne11, PNL Program Manager

August 1987

Prepared by Colorado State University

for Pacific Northwest Laboratory under Contract DE-AC06-76RLO 1830 with the U.S. Department of Energy Agreement BM2931AE 


\section{PREFACE}

Almost universally, the aerodynamic components in computational models of wind turbine response are formulated to modify the available free-stream wind characteristics to account for rotor-induced changes in the wind as the wind approaches the turbine blades. The problem is finding accurate corrections to all features of the wind that change and that determine the aerodynamic forces on the rotor. In the past, the axial and radial distributions of induced mean wind speed changes, computed from simple momentum theory and using a frozen wake assumption, have been the typical free-stream wind adjustments used. Turbulence has not been included as a factor in estimating aerodynamic forces on wind turbine rotors. More recently, however, fluctuating aerodynamic forces on wind turbine rotors have been shown by the Pacific Northwest Laboratory (PNL) to depend strongly upon the properties of both the mean wind and the fluctuating part of the 3-dimensional wind field. In addition, research at PNL has shown that the strong effects of turbulence on the aerodynamics depend not only upon the energy, or magnitude, of the turbulence but also upon the shape, size, and distribution of turbulent eddies in the inflow.

Within the Department of Energy's wind energy research program, PNL is responsible for developing and evaluating the models of the turbulent wind field that are the input to wind turbine aerodynamic models. There is no tested model of the effect of the rotor on the mean and important turbulence characteristics of the airflow from the free stream to the rotor airfoils. Because wind models must result in accurate aerodynamic calculations, PNL has begun research to determine the nature and importance of modifications of wind flowing into the induction, or flow distortion, zone near the rotor.

Developing the new induction model requires data and relations not previously obtained by measurement. First, and best known, is the mean wind speed induction relation. Second, the relations showing the induction effects on the energy, shape, and size of eddies are needed. Third, the relation between these mean and turbulence properties and the distinctly different characteristics of the wind seen by a rotating blade (the rotationally sampled wind) are important. Thus, the measurements of induction effect reported 
herein provide the beginnings of an observational basis for developing a suitable model of the changes in characteristics of wind from the free stream to the vicinity of the rotor.

The first step in our measurement program has been to design a set of wind-tunnel studies based upon a working, scale-model wind turbine. In this program, the 3-dimensional field of turbulent airflow surrounding the rotor is measured from 3 rotor diameters upwind to 0.5 diameter downwind. The first four single-point statistical moments of the turbulent wind are to be calculated from the measurements, along with turbulent spectra and integral length scales of turbulence. A pilot study has been initiated using a wind turbine model lent to PNL by Cornell University, Department of Aerodynamics and Astronautics, and refurbished and modified by PNL. The measurements of the distorted flow have been made in a large wind tunnel under contract by staff of the Fluid Mechanics and Wind Engineering program at Colorado State University (CSU).

The following report was drafted by CSU; it provides the measured, computed, tabulated, and in some instances plotted basic wind parameters for the four cases composing the pilot study measurements. In follow-on work, a second report will present a PNL analysis and interpretation of these basic data for the purpose of advancing our understanding of effects of flow distortion on the turbulence properties of inflow wind to the rotor. A new wind turbine model has been constructed that will allow more precise and complete measurements in the fuller study that will follow this study. A full-scale field study of rotor induction effects on the turbulent airflow is to be undertaken at a wind turbine using the guiding information from the wind tunnel studies and recent theoretical advances.

We publish this report of primarily uninterpreted data for intermediate Reynolds number flows from the pilot wind tunnel study to provide early opportunities for other researchers to incorporate the information into their own work. We hope that this will expand an active exchange between PNL and other researchers on the flow distortion effects on wind near wind turbine rotors. 


\section{$\underline{\text { SUMMARY }}$}

The pilot measurement program described in this report produced data that will be useful in developing more accurate models of the turbulent wind that flows from the free stream into the turning blades of a wind turbine rotor. The flow distortion caused by the interaction of the rotor blades with the wind alters the character of the mean wind velocity and the turbulence properties.

The measurements were taken in a wind tunnel, by a single, nonmoving, 3 -dimensional hot-film anemometer, from 3 rotor diameters upwind to 0.5 rotor diameter downwind of a scale model wind turbine. The rotor diameter was $0.53 \mathrm{~m}$, and the rotor spun at about 26 revolutions per second for these tests. The wind tunnel cross section's width and height were both $1.83 \mathrm{~m}$. The model rotor was $7 \mathrm{~m}$ downwind of a grid of dowels that generated the turbulence. The dowels were $1.27 \mathrm{~cm}$ in diameter and the grid spacing was $12 \mathrm{~cm}$, which increased the turbulence intensity from background of $0.1 \%$ to a value of $1.5 \%$ at the mean wind speeds of 6 and $7.6 \mathrm{~m} / \mathrm{s}$. A rough estimate of the mass flow through the $0.27-\mathrm{m}^{2}$ spinning rotor area indicated that the effective blockage caused by the wind tunnel with a $3.34-\mathrm{m}^{2}$ cross section area was $4 \%$. One can think of the spinning model rotor disk as having acted as though approximately half of its area were open to airflow. The mean speed measurement errors were about $3 \%$ and the wind direction measurement errors were about $2 \%$ for angles less than $15^{\circ}$. Errors in the measurement of the power out of the rotor shaft were \pm 0.5 to $\pm 1.1 \mathrm{~W}$ for tip speed ratios from 4.0 to 7.6 respectively. Maximum power coefficients were in the range 0.28 to 0.35 .

Some very preliminary tracer studies, using He-inflated soap bubbles, of the flow changes near the rotor disk showed: 1) Flow passing downwind through the rotor establishes counter-rotational swirl. 2) About $80^{\circ}$ of the inflow at the 0.75 radius approached the rotor disk parallel to the axis of the rotor, and the other $20 \%$ experienced a single abrupt angular deflection in the region from 0.25 to 0.5 rotor radius upwind of the rotor disk. 3) When the inflow at about tip radius was taken into the tip vortices, the tracer bubble made a complete rotation in a space about equal to the blade length. Using titanium tetrachloride smoke as a tracer resulted in a less detailed, more average, 
picture of the inflow diverging outward in a manner expected from a model of the average axial induction of mean wind velocity change.

The first, second, third and fourth single-point moments of the turbulent flow are computable for four different approach flow conditions 10.1 and $1.5 \%$ turbulence intensity and 6 and $7.6 \mathrm{~m} / \mathrm{s}$ wind speed). Some representative samples of data are plotted to show mean wind and turbulence parameter variation as a function of both axial distance from the rotor and radial distance from the axis of rotation. The induction effects within and beyond the radius of the rotor are resolved with great detail and show maximum magnitudes in the $10 \%$ to $15 \%$ range. A variety of other data are plotted and tabulated. All data are summarized in computer printouts and computer program listings are included. The data presented in this report are expected to be used in detailed analyses to begin to improve models of rotor effects on inflow wind characteristics and for the design of more complete experiments on flow distortion. 
DEFINITION OF SYMBOLS

\begin{tabular}{|c|c|c|}
\hline Symbol & $\begin{array}{l}\text { Pages of } \\
\text { Appearance }\end{array}$ & Definition \\
\hline $\bar{u}$ & $i x, 52-54$ & $\begin{array}{l}\text { Wind speed in wind tunnel centerline of working } \\
\text { section }\end{array}$ \\
\hline T.I. & $i x, 52-54$ & $\sigma_{\mathrm{U}} / \overline{\mathrm{U}}$ of wind tunnel flow \\
\hline $9 \mathrm{c}$ & 4 & Gravitational conversion constant \\
\hline$\Delta P$ & 4 & $\begin{array}{l}\text { Stagnation pressure: static pressure at pitot } \\
\text { static probe in tunnel }\end{array}$ \\
\hline$\rho$ & 4 & $\begin{array}{l}\text { Air density in tunnel, computed from ideal gas } \\
\text { law }\end{array}$ \\
\hline $\mathrm{E}$ & 5 & Voltage output of hotfilm anemometer \\
\hline$A, B, C$ & 5 & $\begin{array}{l}\text { Coefficients and exponents in single hotfilm } \\
\text { calibration equation }\end{array}$ \\
\hline U & 5 & $\begin{array}{l}\text { Instantaneous longitudinal wind speed in tunnel } \\
\text { measured by single hotfilms }\end{array}$ \\
\hline$E_{1}, E_{2}$ & 6 & $\begin{array}{l}\text { Voltage output of anemometer electronics for } \\
\text { each of two films of crossfilm probe }\end{array}$ \\
\hline$i$ & 6 & $\begin{array}{l}\text { Subscript (index) denoting a member of a set } \\
\text { of calibration wind tunnel wind speeds at the } \\
\text { sensor }\end{array}$ \\
\hline j & 6 & $\begin{array}{l}\text { Subscript (index) denoting a member of a set } \\
\text { of calibration wind tunnel wind speeds at the } \\
\text { sensor }\end{array}$ \\
\hline u & 6 & $\begin{array}{l}\text { x-direction (along-tunnel) instantaneous } \\
\text { longitudinal wind velocity measured with a } \\
\text { hotfilm anemometer }\end{array}$ \\
\hline$v$ & 6 & $\begin{array}{l}\text { y-direction (cross-tunnel, horizontal) } \\
\text { instantaneous lateral wind velocity measured } \\
\text { with a hotfilm anemometer }\end{array}$ \\
\hline$w$ & implied on 6 & $\begin{array}{l}\text { z-direction instantaneous vertical wind velocity } \\
\text { measured with a hotfilm anemometer }\end{array}$ \\
\hline $\mathrm{U}_{\mathrm{N} 1}$ & 6 & Wind velocity component nomal to cross-film \#1 \\
\hline $\mathrm{U}_{\mathrm{N} 2}$ & 6 & Wind velocity component normal to cross-film \#2 \\
\hline
\end{tabular}




\begin{tabular}{|c|c|c|}
\hline Symbol & $\begin{array}{c}\text { Pages of } \\
\text { Appearance }\end{array}$ & Definition \\
\hline$\phi_{i}$ & 7 & $\begin{array}{l}\text { Yaw angle between velocity vectors and film } i \\
\phi i=0 \text { denotes wind perpendicular to the film } \\
\text { axis }\end{array}$ \\
\hline k & 7 & $\begin{array}{l}\text { Yaw factor to account for noncosine-law heat } \\
\text { flux relation }\end{array}$ \\
\hline$V_{e f f, i}$ & 8,9 & Effective normal cooling velocity for film $i$ \\
\hline$v$ & 8,9 & $\begin{array}{l}\text { Total instantaneous velocity vector approaching } \\
\text { the sensor array }\end{array}$ \\
\hline$u_{i}, i=1,3$ & 9 & $u$ for $i=1, v$ for $i=2, w$ for $i=3$ \\
\hline$U_{x}$ & 9 & Instantaneous longitudinal velocity; same as $U$ \\
\hline$U_{r}$ & 9 & $\begin{array}{l}\text { Instantaneous crosswind radial velocity } \\
\text { (cylindrical coordinate system) }\end{array}$ \\
\hline U & 9 & $\begin{array}{l}\text { Instantaneous crosswind tangential velocity } \\
\text { (cylindrical coordinate system) }\end{array}$ \\
\hline$x, r, \theta$ & 10 & $\begin{array}{l}\text { Cylindrical coordinates with } x \text { longitudinal to } \\
\text { wind tunnel flow }\end{array}$ \\
\hline $\bar{u}$ & 11 & Mean value of longitudinal wind speed \\
\hline$u^{\prime}$ & 11 & Deviation of $u$ from $\bar{u}$, i.e., $u^{\prime}=u-\bar{u}$ \\
\hline $\mathrm{P}$ & 12 & Power out of turbine rotor at prony brake \\
\hline A & 12 & Rotor disk area \\
\hline
\end{tabular}




\section{CONTENTS}

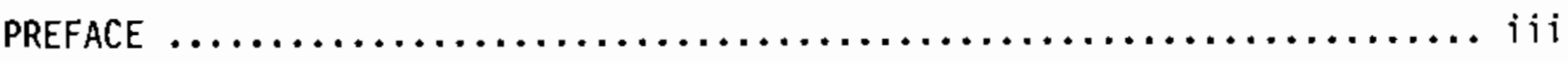

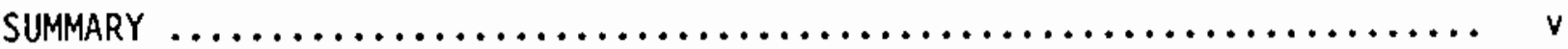

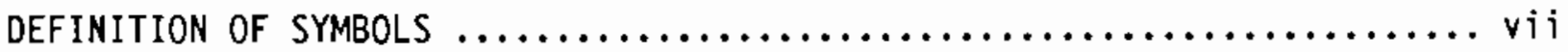

1.D INTRODUCTION $\ldots \ldots \ldots \ldots \ldots \ldots \ldots \ldots \ldots \ldots \ldots \ldots \ldots \ldots \ldots \ldots \ldots \ldots \ldots \ldots$

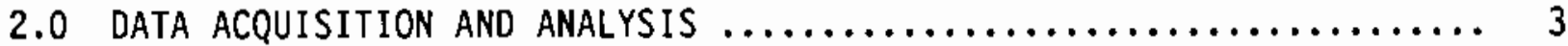

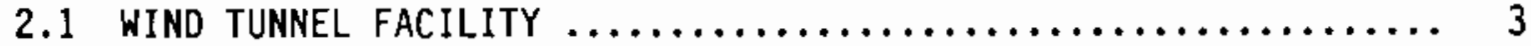

2.2 WIND TURBINE MODEL $\ldots \ldots \ldots \ldots \ldots \ldots \ldots \ldots \ldots \ldots \ldots \ldots \ldots \ldots \ldots \ldots \ldots \ldots$

2.3 FLOW VISUALIZATION TECHNIQUES $\ldots \ldots \ldots \ldots \ldots \ldots \ldots \ldots \ldots \ldots \ldots$

2.4 VELOC.ITY MEASUREMENTS $\ldots \ldots \ldots \ldots \ldots \ldots \ldots \ldots \ldots \ldots \ldots \ldots \ldots$

2.4.1 Pitot-Static Probe Measurements ............... 4

2.4.2 Single-Hot-Film Probe Measurements $\ldots \ldots \ldots \ldots \ldots \ldots$

2.4.3 Cross-Film Probe Measurements $\ldots \ldots \ldots \ldots \ldots \ldots \ldots \ldots$

2.4.4 3-Dimensional Hot-Film Probe Measurements .......... 7

2.5 POWER MEASUREMENTS $\ldots \ldots \ldots \ldots \ldots \ldots \ldots \ldots \ldots \ldots \ldots \ldots \ldots \ldots \ldots \ldots$

3.0 TEST PROGRAM AND DATA $\ldots \ldots \ldots \ldots \ldots \ldots \ldots \ldots \ldots \ldots \ldots \ldots \ldots \ldots \ldots \ldots$

3.1 APPROACH WIND CHARACTERISTICS $\ldots \ldots \ldots \ldots \ldots \ldots \ldots \ldots \ldots \ldots \ldots$

3.2 POWER COEFFICIENT RESULTS $\ldots \ldots \ldots \ldots \ldots \ldots \ldots \ldots \ldots \ldots \ldots \ldots$

3.3 WIND CHARACTERISTICS NEAR THE ROTOR $\ldots \ldots \ldots \ldots \ldots \ldots \ldots \ldots \ldots \ldots$

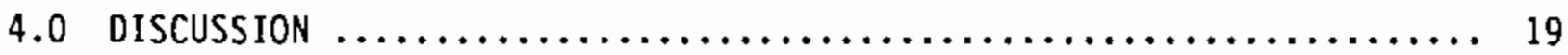

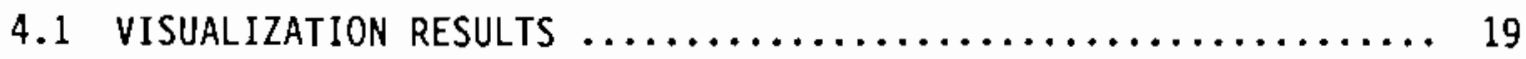

4.2 WIND FIELD RESULTS $\ldots \ldots \ldots \ldots \ldots \ldots \ldots \ldots \ldots \ldots \ldots \ldots \ldots \ldots \ldots$

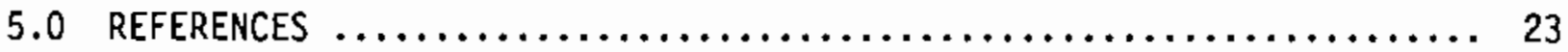

APPENDIX A - COORDINATE TRANSFORMATIONS $\ldots \ldots \ldots \ldots \ldots \ldots \ldots \ldots \ldots \ldots \ldots$

APPENDIX B - COMPUTER PROGRAMS $\ldots \ldots \ldots \ldots \ldots \ldots \ldots \ldots \ldots \ldots \ldots \ldots \ldots \ldots$ 


\section{FIGURES}

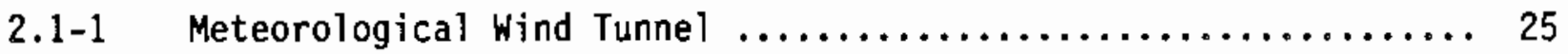

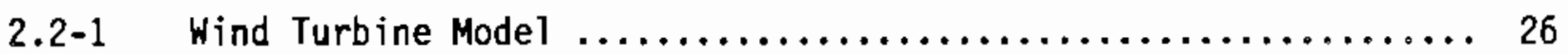

2.2-2 Wind Turbine Mounting Diagram $\ldots \ldots \ldots \ldots \ldots \ldots \ldots \ldots \ldots \ldots . \ldots \ldots$

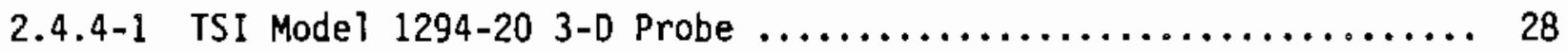

2.4.4-2 Spectral Response of Different Anemometer Probes ........... 29

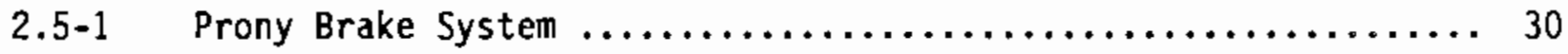

Velocity Fluctuation Power Spectrums
for Approach Flows 3 and $4 . \ldots \ldots \ldots \ldots \ldots \ldots \ldots \ldots \ldots, 31$

3.2-1 Power Coefficient Versus Tip Speed Ratio $\ldots \ldots \ldots \ldots \ldots \ldots \ldots . \ldots . \ldots 2$

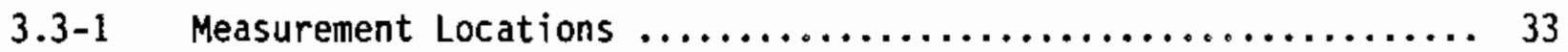

4.2-1 Mean Axial Velocities for Approach Flow Case I ............. 34

4.2-2 Axial Velocity Component Time Series for Run No. 1043,

4.2-3a, Normalized Mean Axial Velocity Change Versus Axial

$b, c, d$ Distance for Approach Flow Cases I, II, III, and IV,

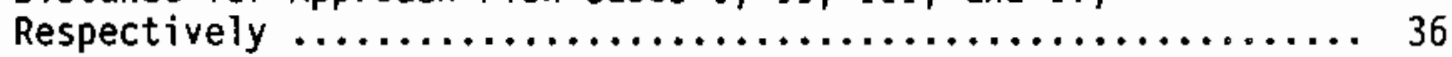

4.2-4 Normalized Mean Radial Velocity Change Versus Axial Distance for Approach Flow Case II $\ldots \ldots \ldots \ldots \ldots \ldots \ldots \ldots \ldots, 40$

4.2-5 Normalized Mass Angular Velocity Change Versus Axial Distance for Approach Flow Case II $\ldots \ldots \ldots \ldots \ldots \ldots \ldots \ldots \ldots, 41$

4.2-6 Angular Velocity Component Time Series for Run No. $1043 \ldots \ldots . .42$

4.2-7a Axial Turbulent Intensity Versus Axial Distance for Approach Flow Case II $\ldots \ldots \ldots \ldots \ldots \ldots \ldots \ldots \ldots \ldots \ldots, 43$

4.2-7b Axial Turbulent Intensity Versus Axial Distance for Approach Flow Case IV ............................ 44

4.2-8 Axial Flatness Factor Versus Axial Distance for Approach Flow Case IV $\ldots \ldots \ldots \ldots \ldots \ldots \ldots \ldots \ldots \ldots, 45$

4.2-9 Angle of Attach Time Series for Run No. $1043 \ldots \ldots \ldots \ldots \ldots \ldots$....... 46

A.1 Sensor, Probe, and Tunnel Coordinate Systems $\ldots \ldots \ldots \ldots \ldots \ldots$. . 6 


\section{$\underline{\text { TABLES }}$}

2.2-1 Blade Pitch Versus Rotor Radius $\ldots \ldots \ldots \ldots \ldots \ldots \ldots \ldots \ldots . \ldots, \ldots 7$

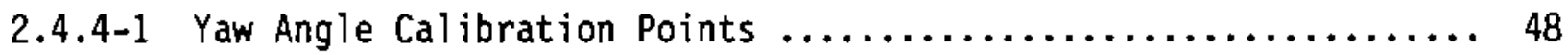

2.4.4-2 Comparison of Actual and Calculated Velocity

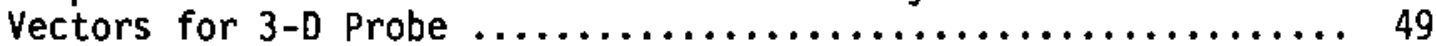

2.4.4-3 Comparative Response of Anemometer Probes $\ldots \ldots \ldots \ldots \ldots \ldots \ldots .50$

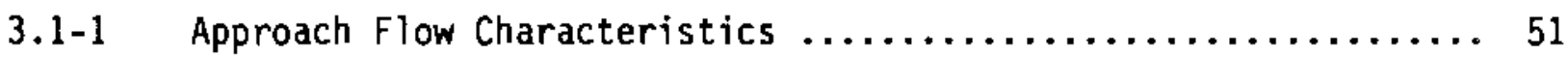

3.2-1 Power Measurement Test for $\bar{U}=6.0 \mathrm{~m} / \mathrm{s}$, T.I. $=0.1 \% \ldots \ldots \ldots 52$

$3.2-2$ Power Measurement Test for $\bar{U}=7.6 \mathrm{~m} / \mathrm{s}$, T.I. $=0.1 \% \ldots \ldots \ldots 53$

$3.2-3$ Power Measurement Test for $\bar{U}=7.6 \mathrm{~m} / \mathrm{s}$, T.I. $=1.5 \% \ldots \ldots \ldots 54$

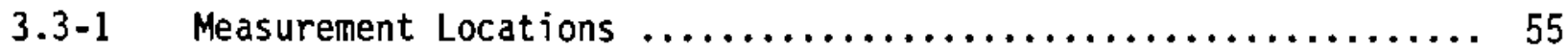

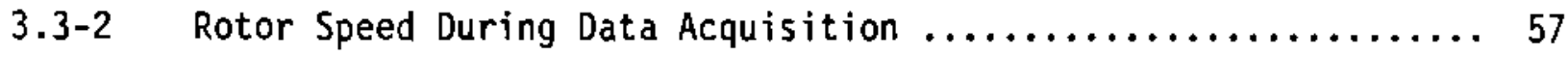

3.3-3 Near-Field Velocity Information $\ldots \ldots \ldots \ldots \ldots \ldots \ldots \ldots \ldots . \ldots . \ldots . \ldots$ 
. 


\subsection{INTRODUCTION}

Aerodynamicists currently use wind field and turbulence information to calculate the character of dynamic loading that large wind-generator rotors receive (Hansen 1979; Kareem 1981; Cliff and Ficht1 1978; Ficht1 1983). Unfortunately, these turbulence scales and intensities may be distorted by the pressure of the rotor flow field before they actually interact with the rotor blades. Indeed, wind-generator induction effects and streamline divergence caused by the hub and tower may significantly distort free wind field values.

In recent years, a limited number of model and field-scale measurement studies have examined near- and far-field turbine rotor wakes (Riley et al. 1980; Eberle 1981; Baker and Walker 1982). These wake studies were made to evaluate the influence of upwind turbines on downwind installations; little information appears in the literature concerning possible induction effects.

It is the purpose of this report to provide experimental data on the wind field surrounding a single model wind turbine rotor disk. These data should provide an improved physical insight into the induction effects of the air flow as it approaches the wind turbine. This insight should in turn improve an analytical model's predictive capabilities. A tradeoff between a well-controlled experiment in a wind tunnel with $\mathrm{Re}_{\text {chord }} \leq 150,000$ and a very difficult full-size turbine measurement was made in favor of the wind tunnel in the first round of experiments. The analys is of results and scale-up efforts to follow in later reports will consider the applicable differences in physics.

A scaled model of a horizontal-axis wind turbine (a two-bladed rotor of diameter $53 \mathrm{~cm}$ ) was placed into the Meteorological Wind Tunnel (MWT) facility at Colorado State University (cross-section width of $183 \mathrm{~cm}$ ). Four different approach flow conditions were studied: low and moderate turbulence levels $(0.1 \%$ and $1.5 \%$ intensity) at both 6 and $7.6 \mathrm{~m} / \mathrm{s}$ freestream air velocities. For each of these flow conditions the rotor power coefficient versus tip speed ratio was obtained, and the 3-dimensional velocity field from 3 rotor diameters upwind to 0.5 diameter downwind was tabulated. 
The power output of the rotor was obtained via a simple prony brake friction device that imparts a torque (measured by the deflection of a spring). to the spinning shaft of the wind turbine. The rotor speed, measured by a strobe light, was observed to vary with load from $900 \mathrm{rpm}$ up to $2100 \mathrm{rpm}$ for the flow conditions described above.

The 3-dimensional velocity field was measured via a three-hot-film probe (TSI $1294^{(a)}$ ) capable of measuring rapidly varying velocity vector direction and magnitude within a rectangular coordinate system octant. The transducer response was directed to an analog to digital converter connected to a minicomputer system for on-line data reduction. The statistical values computed from the u-v-w time series in axisymmetrical coordinates for each position are:

1. mean, rms, skewness, and flatness of the axial velocity component

2. mean, rms, skewness, and flatness of the radial velocity component

3. mean, rms, skewness, and flatness of the angular velocity component

4. mean velocity vector angles from the axial, radial, and angular coordinate directions

5. Reynolds stresses

6. mean, rms, skewness, and flatness of the angular deviations about the axial axis

7. mean, rms, skewness, and flatness of the angular deviations about the radial axis

8. mean, rms, skewness, and flatness of the angular deviations about the angular axis.

Details of the measurement techniques are provided in Section 2.0. The test program and data results are given in Section 3.0. A short discussion of the implications of this data set is included in Section 4.0.

(a) Manufactured by TSI, Inc., St. Paul, Minnesota. 


\subsection{DATA ACQUISITION AND ANALYSIS}

Laboratory measurement techniques are discussed in this section. Some of the methods used are conventional and need little elaboration.

\subsection{WIND TUNNEL FACILITY}

The experiments were performed in the Meteorological Wind Tunnel (MWT) shown in Figure 2.1 ( $\mathrm{Plate}$ and Cermak 1963). This wind tunnel has a wind speed range of 0.3 to $30 \mathrm{~m} / \mathrm{s}$. The approach flow turbulent intensity varies upward from $0.1 \%$. The test section in which the model wind turbine was located had a cross-sectional area of $3.34 \mathrm{~m}^{2}(1.83 \mathrm{~m} \times 1.83 \mathrm{~m})$. The model was located $7 \mathrm{~m}$ downwind from the convergent entrance to the test section. For the grid turbulence tests (turbulent intensity of $1.5 \%$ ), a dowel grid was mounted at the test section entrance. The dowels were $1.27 \mathrm{~cm}$ in diameter and spaced $12 \mathrm{~cm}$ apart. The wind turbine was placed in the spatially uniform velocity field downwind of the entrance.

\subsection{WIND TURBINE MODEL}

The wind turbine model (Figure 2.2-1) was built by Mr. Peter Bushnell of Cornell University (Bushnell 1983, 1984). Figure 2.2-2 displays the mounting arrangement of this horizontal-axis wind turbine. The rotor shaft was mounted on two support rods; each rod holds a low-friction roller bearing to ensure rotor shaft rotational freedom. At the downwind end of the rotor shaft was mounted a small DC generator. A calibration of the generator's voltage variation versus rotational speed (obtained through the use of a strobe light) yielded the conversion equation $\mathrm{rpm}=744 \times$ (volts).

The prony brake consisted of a spring mounted next to a ruler, a leather friction belt, an aluminum brake drum mounted on the rotor shaft, and a weight bucket. To start the wind turbine spinning, one manually lifted the brake assembly away from the brake drum until the turbine reached a rotational speed above its resonant frequency of around $1000 \mathrm{rpm}$. Once above this speed the prony brake was set back in place on the brake drum. The amount of weight placed in the bucket determined the rotor speed. 
The rotor diameter was $53.4 \mathrm{~cm}$. The rotor blades were made of balsa wood covered with epoxy. The blade shape was that of a NACA 4415 airfoil section. A steel pin at the base of each blade was connected to the hub with a set screw, and the hub was also connected to the rotor shaft with set screws. The blade chord was constant $(4.76 \mathrm{~cm})$ over the entire radial length of the blade. The tips were cut square. Table 2.2-1 displays the blade twist angle versus radial distance. The wind turbine was designed to operate at $1400 \mathrm{rpm}$, with a tip speed ratio of 5 and a lift coefficient of 1.0 .

As stated in Section 2.1, the wind tunnel cross-sectional area was $3.34 \mathrm{~m}^{2}$, whereas the rotor disk area was $0.268 \mathrm{~m}^{2}$. A rough estimate of the mass flow through the spinning rotor disk indicates that approximately onehalf of the rotor disk acted as open area. Thus the blocking area presented by the spinning rotor disk was $4 \%$ of the wind tunnel cross-sectional area.

\subsection{FLOW VISUALIZATION TECHNIQUES}

Video movies (VHS) were taken of helium soap bubbles produced by a bubble generator as they floated through or by the spinning rotor blades. Video movies were also taken of a smoke plume produced by titanium tetrachloride as it flowed past the rotor blades.

\subsection{VELOCITY MEASUREMENTS}

Velocity measurements were made with pitot probes, single hot films, cross films and 3-dimensional hot-film systems. Each of these instruments will be described in the following sections.

\subsubsection{Pitot-Static Probe Measurements}

Pitot-static probes were used as a velocity standard during the calibration of the different hot-film systems and to provide the reference upwind velocity measurement. The principles of operation of pitot-static probes are described in any fundamental text on fluid mechanics and will not be discussed in detail here. The operational relationship for these probes is $U=\left(2 g_{c} \Delta P / \rho\right) 1 / 2$, where $U=$ velocity, $g_{C}=$ gravitational conversion constant, $\Delta P=$ difference between static and stagnation pressures, and $\rho=$ the air density. $\rho$ was calculated from the ideal gas law and $\Delta \mathrm{P}$ was measured using an 
electronic differential pressure manometer. The pitot-static probe measurements were accurate to within $\pm 2 \%$ of the actual velocity.

\subsubsection{Single-Hot-Film Probe Measurements}

Single-hot-film (TSI 1210 Sensor) measurements were used to document the longitudinal turbulence levels for the four different approach flow conditions and as an error estimator for the cross-film and 3-D film measurements. To calibrate the single-film probe, it was placed into the wind tunnel next to the pitot-static probe. The anemoneter voltages were digitized for several velocities covering the range of interest. These voltage-velocity $(E, U)$ pairs were then regressed to the equation $E^{2}=A+B U C$ via a least squares approach to assumed values of exponent $c$. Convergence to the minimum square was accelerated by using the secant method to find the best new estimate of $c$. To take measurements with this calibrated single-film probe, the anemometer voltage was digitized and stored on a disk file within a minicomputer system. This voltage time series was converted to a velocity time series using the inverse of the calibration equation:

$$
U=\left[\left(E^{2}-A\right) / B\right]^{1 / C}
$$

This velocity time series was then analyzed for pertinent statistical quantities, such as mean, mean square, etc., and tabulated at the terminal.

The calibration curve yielded hot-film anemometer velocities that were always within $\pm 1 \%$ of the velocities calculated from the pitot-static probe. The accuracy of a single hot-film during the measurement of turbulent flow quantities is dependent upon the flow regime being measured. During the present study the single-film probe was used only in conditions of no mean

wind shear and low turbulent intensity (less than 1.5\%). For these conditions the velocity time series should be accurate to within $\pm 2 \%$.

\subsubsection{Cross-Film Probe Measurements}

Cross-film (TSI 1241) measurements were used to document the lateral and vertical turbulent level for one approach flow condition and as an error estimator for the 3-D hot-film measurements. To calibrate the cross-film probe, it was placed next to the pitot-static probe. Each of the two films 
were yawed 45 degrees from the direction of the mean velocity vector. The anemometer voltages were digitized for several velocities covering the range of interest. These voltage-velocity pairs $\left(E_{1}, U_{;} E_{2}, U\right)$ were fitted to the equation

$$
\left(E_{i, j}\right)^{2}=A_{i}+B_{i}\left[\left(U_{j} \cos \left(45^{\circ}\right)\right]^{C} i\right.
$$

via a least square approach with the secant method used to find the best new estimate of exponent, $c_{i}$. Strict cosine dependence of the heat flux from the film versus yaw angle was assumed; and thus, no yaw angle calibration was necessary. During measurements made with this calibrated cross film probe it was placed so that the mean velocity vector was at $45^{\circ}$ to each film, while both films were located in the $x-y$ plane. The voltage output from each anemometer was digitized, and the resulting voltage time series were converted to velocity time series via the equations

$$
u=\left(U_{N 1}+U_{N 2}\right) / 1.414 \quad v=\left(U_{N 1}-U_{N 2}\right) / 1.414
$$

$$
\text { where } \begin{aligned}
U_{N i} & =\left[\left(E_{i}^{2}-A_{i}\right) / B_{i}\right]^{C} \\
& =u \sin \phi_{i}+v \cos \phi i ; \quad \phi 1=45^{\circ}, \phi 2=135^{\circ} \\
U_{N i} & =\text { velocity component normal to film } i \\
u & =\text { longitudinal velocity component } \\
v & =\text { lateral velocity component }
\end{aligned}
$$

To measure vertical velocity components the probe was rotated $90^{\circ}$ so that both films were in the $x-z$ plane. The reduction equations are similar to those above.

The calibration curve yielded hot-film anemometer velocities that were always within $\pm 1 \%$ of the velocities calculated from the pitot-static probe. Since no yaw calibrations were performed, no estimate can be made of inaccuracies introduced by the cosine law assumption. From past experiences it is felt that this cross $-\mathrm{film}$ reduction method should be accurate to within $\pm 10 \%$ for a low-intensity, nearly isotropic flow. 


\subsubsection{3-Dimensional Hot-Film Probe Measurements}

A TSI model 1294-20 probe was used for all measurements behind and to the side of the wind turbine. Note that if wind direction is outside the probe's primary octant, the probe does not detect the difference. An estimate of the percent of time the wind was ambiguous is given in Column 4 of Table 3.3-3. A specially made probe, similar to the TSI 1294-20 but with a $90^{\circ}$ bend in the probe shaft $3.8 \mathrm{~cm}$ back from the sensors, was used for all measurements upwind of the wind turbine. The data reduction scheme used was similar to that described in TSI Technical Bulletin 8. The TSI model 1294-20 probe has three orthogonally mounted, cylindrical hot films (dia $=0.051 \mathrm{~mm}$ ), each doubly supported (Figure 2.4.4-1). The probe can measure total vector velocities that are contained within the single octant defined by the three film positions.

To calibrate the 1294 3-0 probe, it was placed in the wind tunnel (the probe support axis parallel to air flow) next to the pitot-static probe. In this position the angle between each sensor and the flow vector is $54.74^{\circ}$; thus, the yaw angles for each sensor are $35.26^{\circ}$ (Figure 2.4.4-1). The voltages from each anemometer channel ( 3 total) were digitized for several velocities covering the range of interest. These voltage-velocity pairs $\left(E_{i}, U_{i} ; i=\right.$ $1,3)$, at a fixed angle, were fit to the equation

$$
E_{i, j}^{2}=A_{i}+B_{i}^{\prime}\left(U_{j}\right)^{C_{i}} ; \quad i=1,3 ; \quad j=1, n
$$

where $B_{i}^{\prime}=B_{i}\left(\cos ^{2} \phi_{i}+k^{2} \sin ^{2} \phi_{j}\right)^{c_{i} / 2}$

$\phi_{j}=$ yaw angle between velocity vector and film $i$

$k=$ yaw factor

$n=$ no. of calibration points

via a least-squares fit with the secant method to find the best new estimate of the exponent $c_{j}$. Note that if the yaw factor, $k$, equals zero then a simple cosine law dependence of heat flux exists. To determine the yaw factor, $k$, the air velocity was set at a constant value, and the probe was rotated about its $y$ axis and then its $x$ axis so that voltage samples could be taken for a 
wide range of yaw angle variations on all three films. Table 2.4.4-1 lists the yaw angles on the different films for the $y-x$ axis rotations that were used. These voltage-yaw angles $\left(E_{i}, \phi_{i} ; i=1,3\right)$ were regressed to the equation

$$
B_{i}^{\prime}=\left(E_{i, j}^{2}-A_{i}\right) / U^{C_{i}}=B_{i}\left(\cos ^{2} \phi_{i, j}+k_{i}^{2} \sin ^{2} \phi_{i, j}\right)^{C_{i} / 2}
$$

where $j=1,3$ and $j=1, n$, via a least squares approach with the secant method to find the best new estimate for the yaw factor, $k_{j} . A_{i}, B_{i}, C_{j}$ and $k_{j}$ for all three films are thus obtained, but for the reduction algorithm used $k j$ must be equal for all films and not a function of velocity. Providing that all three films have a similar aspect ratio, then all three $k_{i}$ values should be of similar magnitude and forcing them equal does not introduce large errors. Once a value for $k$ is specified then a least-squares fit will determine the optimal values for $B_{i}$. Once the value of $k$ was determined for a specific probe, it was no longer necessary to do angle calibrations.

Given the calibration constants $A_{i}, B_{i}, C_{j}$ and the equations

$$
E_{i}^{2}=A_{i}+B_{i}\left(V_{\text {eff, } i}\right)^{C_{i}} ; \quad i=1,3
$$

where $V_{\text {eff, } i}=V\left(\cos ^{2} \phi_{j}+k^{2} \sin ^{2} \phi_{j}\right)^{1 / 2} ; i=1,3$

$V_{e f f, i}=$ effective cooling velocity for film $i$

$V=$ total velocity vector approaching sensor array

and using the trigonometric relationships that exist between the three yaw angles

$$
\sum_{i=1}^{3} \sin ^{2} \phi_{i}=1 \text { and } \sum_{i=1}^{3} \cos ^{2} \phi_{i}=2
$$

one finds that the total velocity approaching the sensor array, $v$, is calculated from 


$$
v=\left[\sum_{i=1}^{3} v_{\text {eff }, i}^{2} /\left(2+k^{2}\right)\right]^{1 / 2} ;
$$

the yaw angles, $\phi i$, are

$$
\phi_{i}=\arcsin \left[\left(1-v_{e f f, i}^{2} / v^{2}\right) /\left(1-k^{2}\right)\right]^{1 / 2} ;
$$

the angles, $\phi_{i}$, between a sensor coordinate axis and the velocity vector are

$$
\phi_{i}=90^{\circ}-\phi_{i} ;
$$

and the $u_{i}$ velocity components (in the sensor coordinate system of $x_{i}$ respectively) of the total velocity, $v$, are

$$
u_{i}=v \sin \phi_{i}=\left[\left(v^{2}-v_{e f f, i}^{2}\right) /\left(1-k^{2}\right)\right]^{1 / 2} .
$$

In the above equations $V_{e f f} i$ is given by

$$
v_{\text {eff }, i}=\left[\left(E_{i}^{2}-A_{j}\right) / B_{i}\right]^{1 / c_{i}} \text {. }
$$

The algorithm finds the velocity components, $u_{i}$, that are along the sensor coordinate directions. Thus it is necessary to transform the $u_{i}$ values from sensor coordinates to $u_{j}$ values in wind tunnel coordinates. The details of this transformation are given in Appendix $A\left(u_{1} \equiv u_{1}, u_{2} \equiv v_{,} u_{3} \equiv w\right)$.

The computer programs (listed in Appendix B), used to calibrate and take data with the 3-D probes, were:

1. CAL3D - This program finds the calibration constants, $A_{i}, B_{i}, C_{i}$, $k(i=1,3)$ and writes them to a disk file for later retrieval by a reduction program. 
2. DAT3D - This program creates a digital voltage time series for each of the 3 channels, converts the voltage values into $U_{x}, U_{r}, U_{\theta}$ velocity time series files (in tunnel coordinates) and calculates each time series minimum, maximum, mean, ms, skewness, and flatness.

3. DAT1 - This program creates a digital voltage time series for each of the 3 channels and stores it on the computer's disk. It was used to acquire data in a rapid sequence, as opposed to waiting for files to be reduced into velocity values.

4. DAT2 - This program picks up the digital voltage time series created by DAT1 and converts them into $U_{x}, U_{r}, U_{\theta}$ velocity time series. Then it calculates each time series minimum, maximum, mean, rms, skewness, and flatness.

5. ANGTM - This program creates the time series of the angular deviations about the tunnels $x, r, \theta$ coordinates and computes the minimum, maximum, mean, rms, skewness, and flatness. It is scheduled from inside DAT2.

6. PRT3 - This program prints out the reduced data that were calculated in program DAT2 in the format seen later in this report.

The accuracy of 3-D velocity measurements and associated reduction algorithms can be estimated by directing different known mean velocity vectors at the probe. Table 2.4.4-2 sumnarizes such tests. Table 2.4.4-2 shows that the mean velocity magnitude is generally within $\pm 3{ }^{\circ}$ of the actual value. The error in angle calculations is seen to be approximately $\pm 2^{\circ}$ for angular deviations of $15^{\circ}$ or less and somewhat larger than this for greater deviations.

Another test of the accuracy of the 3-D probe is to compare the measurements of different turbulent statistics to those obtained from more conventional probes, such as single-film and cross-film probes. Table 2.4.4-3 displays the mean and rms turbulence magnitudes calculated from a single film, a cross film, a TSI 1294-60 3-D probe, (a) and a TSI 1294-20 probe for two different turbulence conditions. The mean and rms velocity comparisons between

(a) The 1294-60 probe has larger diameter sensors and the sensors are separated by greater distances than the 1294-20 probe. 
the single-film and the cross-film are within the bounds specified earlier in Section 2.4.3, that is $\sim 2 \%$ and $\sim 10 \%$ respectively. The $3-D$ probes compare to these $\bar{u}$ and $u^{\prime}$ measurements within $\sim 3.5 \%$ and $\sim 10 \%$ respectively. The $v^{\prime}$ and $w^{\prime}$ magnitude comparisons to the cross film results suggest errors of $\sim 15 \%$ (except for $v^{\prime}$ in grid turb where $29 \%$ error was observed). Figure 2.4.4-3 displays the spectral responses of these four different probes. The single-film, crossfilm, and TSI 1294-20 3-D probes all provide equivalent frequency response out to $800 \mathrm{~Hz}$. The TSI 1294-60 3-D probe has a large sensing volume; hence, its response rolls off rapidly above $100 \mathrm{~Hz}$. The large-sensor-volume TSI 1294$603-D$ probe was not used for any data acquisition during the remainder of the study.

\subsection{POWER MEASUREMENTS}

The power output from the wind turbine was calculated in the following manner (see Figure 2.5-1):

1. The spring force constant was calculated to be $54.2 \mathrm{~N} / \mathrm{m}$ by measuring the deflection of the spring for loads varying between 0 and $453 \mathrm{~g}$.

2. $Z_{0}$, the spring zero deflection point as mounted in the prony brake system, was calculated from the equation (see upper part of

Figure 2.5-1)

$$
W=\left(z_{s}-z_{0}\right) k \text { or } z_{0}=z_{s}-W / k
$$

for several different weights up to $453 \mathrm{~g}$. The average of these $Z_{0}$ values was used as the spring zero deflection point.

3. The rotor was started for the specific approach flow conditions being tested. Over a range of weights placed in the bucket the rotor speed, $\Omega$, and the spring deflection under dynamic conditions were recorded.

4. The frictional force, $F$, applied by the prony brake against the brake drum is $F=W-T_{d}$. The torque, $\tau$, applied to the rotor shaft is then $\tau=F \times R$ and the power is $P=\tau \times \Omega$. 
5. The power coefficient, $C_{p}$, is $C_{p}=P /\left(1 / 2 \rho A U^{3}\right)$ where $\rho=1.0 \mathrm{~kg} / \mathrm{m}^{3}$ is the density of air in the tunnel, $A$ is the rotor disk area, and $U$ is the approach flow mean wind speed. The tip speed ratio, $X$, is given by $\Omega R / U$.

A calculation of the drag force on the wire connecting the weight to the prony brake assembly was determined to be small (equivalent deflection in spring of $0.3 \mathrm{~mm}$ ) compared to the hysteresis errors accompanied with the est imate of the springs zero deflection point $( \pm 5 \mathrm{~mm})$. This error in the estimation of $Z_{0}$ overshadows all other errors in the procedure to calculate the power, $P$. This error in $P$ varies from $\pm 1.1 W$ for the highest tip speed ratios down to $\pm 0.5 \mathrm{~W}$ for the lowest tip speed ratios. 


\subsection{TEST PROGRAM AND DATA}

The test program consisted of documenting the different approach flow characteristics, measurement of the perfornance (power coefficient versus tip speed ratio) of the model wind turbine, and the tabulation of the flow field near the spinning rotor. These topics are discussed in the following sections.

\subsection{APPROACH WIND CHARACTERISTICS}

Four different approach flow characteristics were studied: two different mean wind speeds and two different turbulent intensities. They were:

1. low turbulence $(\sim 0.1 \%)$ and mean wind speed $=6.0 \mathrm{~m} / \mathrm{s}$,

2. low turbulence $(\sim 0.1 \%)$ and mean wind speed $=7.6 \mathrm{~m} / \mathrm{s}$,

3. moderate turbulence $(\sim 1.5 \%)$ and mean wind speed $=6.0 \mathrm{~m} / \mathrm{s}$,

4. moderate turbulence $(\sim 1.5 \%)$ and mean wind speed $=7.6 \mathrm{~m} / \mathrm{s}$.

The approach flow was uniform and steady (within $\pm 2 \%$ ) over the center portion of the wind tunnel. The moderate turbulence cases were produced by the placement of a grid, described in Section 2.1, at the entrance of the test section. Measurements of the approach flow character were made by a single-film probe and the TSI 1294-20 3-D hot-film probe. The turbulent statistics describing these approach flows are sumnarized in Table 3.1-1. The longitudinal and vertical velocity component power spectrums for Flows 3 and 4 are shown in Figure 3.1-1.

\subsection{POWER COEFFICIENT RESULTS}

The power output of the model wind turbine was measured for three different conditions:

mean velocity

turbutent intensity

\begin{tabular}{|c|c|c|}
\hline \multicolumn{3}{|c|}{ Case } \\
\hline I & III & I I I \\
\hline 6.0 & 7.6 & 7.6 \\
\hline $0.1 \%$ & $0.1 \%$ & $1.5 \%$ \\
\hline
\end{tabular}


Tables 3.2-1 to 3.2-3 list the numerical values obtained from the Cases I, II, and III respectively. Figure 3.2-1 displays the power coefficient versus tip speed ratio.

\subsection{WIND CHARACTERISTIC NEAR THE ROTOR}

Figure 3.3-1 indicates the 58 spatial grid points at which velocity measurements were taken with a TSI 1294-20 3-dimensional hot-film probe. Table 3.3-1 lists the coordinates of each spatial location. Note that the right-most digit of the three-digit position number always represents the radial distance in 0.125 rotor diameters and the left two digits represent the axial distance. Four different approach flow conditions were tested, as described in Section 3.1. These were:

$\begin{array}{ccc}\text { Case No. } & \begin{array}{c}\text { Mass Velocity } \\ (\mathrm{m} / \mathrm{s})\end{array} & \begin{array}{c}\text { Turb. Intensity } \\ (\%)\end{array} \\ 1 & 6.0 & 0.1 \\ 2 & 7.6 & 0.1 \\ 3 & 6.0 & 1.5 \\ 4 & 7.6 & 1.5\end{array}$

The nomenclature used for test designations was case number followed by position number. Thus run number 3062 would be for approach flow case number $3(U=6.0 \mathrm{~m} / \mathrm{s}, \mathrm{T} . I .=1.5 \%)$ at position 62 which from Table 3.3-1 was at $x=$ $-0.134 \mathrm{~m}, r=0.134 \mathrm{~m}, \theta=180^{\circ}$.

For Cases 1 and 3 a mass of 454 grams was placed into the prony brake systems bucket. For Cases 2 and 4 a mass of 906 grams was used. Unfortunately, the amount of friction between the prony brake's leather belt and the aluminum brake drum varied as the brake heated up and as aluminum oxide coated both belt and drum. Thus, the speed and power output of the wind turbine varied substantially during the test period. Table 3.3-2 documents the approximate rotor speed for each velocity measurement. The variation in rotor speed during the data-acquisition period for a single case was as large as $\pm 150 \mathrm{rpm}$.

Table 3.3-3 summarizes the pertinent turbulent statistics for all measurements of the 3 -dimensional velocity field near the rotor. All measurements 
were made with a digital sampling rate of $1563 \mathrm{~Hz}$ for a total of 32,384 samples. Thus, given a rotor speed of approximately $1400 \mathrm{rpm}$, the velocity time series included 967 passes of a rotor blade (rotor has 2 blades). Again, with a rotor speed of $\sim 1400 \mathrm{rpm}$ at a $1563 \mathrm{~Hz}$ sample rate, 67 samples were taken for every revolution of the rotor, or a sample was taken every $5.37^{\circ}$ of rotation. These time series records were of sufficient length to insure an accuracy of $\pm 5 \%$ in the computation of the mean, rms, and flatness.

The following is a description of the column headers that appear in Table 3.3-3.

1. FILE NAME - The component velocity time series at each measurement location were saved on digital tape by these names. The last four characters are equivalent to the run number described above. The first two characters define the velocity component.

UU is for the axial component.

$W$ is for the radial component.

$W W$ is for the angular component.

2. AXIS - 1 designates the axial coordinate.

2 designates the radial coordinate.

3 designates the angular coordinate.

3. POSITION - Measurement position in meters for the axial and radial coordinates, and in degrees for the angular coordinate. See Figure 3.3-1 for further guidance.

4. LIMITS EXCEEDED - This was the number of times a velocity vector came within $10^{\circ}$ of leaving the measurement octant of the sensor coordinate system. In many of these excursions the velocity vector will have left the measurement octant resulting in a calculational error. In this case the velocity component (in sensor coordinates) is set to zero before conversion to tunnel coordinates. In some cases the velocity vector may pass out of the measurement octant but not result in calculation errors; thus the approach places erroneous values into the time series. Records that have a significant number of these errors should not be trusted, and those that 
only have a few have dubious accuracy, particularly in the higher moments, such as skewness and flatness.

5. VELOCITY (MEAN) - Mean velocity component in $\mathrm{m} / \mathrm{s}$.

6. VELOCITY (ANGLE) - Angle (degrees) from the specified AXIS to the mean velocity vector.

7. VELOCITY (MIN) - Minimum velocity in $\mathrm{m} / \mathrm{s}$.

8. VELOCITY (MAX) - Maximum velocity in $\mathrm{m} / \mathrm{s}$.

9. VELOCITY (RMS) - Root mean square of the velocity fluctuations in $\mathrm{m} / \mathrm{s}$.

10. VELOCITY (SKEWNESS) - Third moment of the velocity fluctuations normalized by the RMS. It is zero for a sine wave and a random signal.

11. VELOCITY (FLATNESS) - Fourth moment of the velocity fluctuations normalized by the RMS. It is 1.5 for a sine wave and 3.0 for a random signal.

12. VELOCITY (REYNOLDS STRESS) - This is not in the units of stress.

It is simply the mean product of the indicated velocity components.

$U$ for the axial component.

$\checkmark$ for the radial component.

$W$ for the angular component.

Units are $\mathrm{m} / \mathrm{s}^{2}$.

13. ANGLE (MEAN) - Mean value of the angular deviations about the indicated axis. The units are degrees.

14. ANGLE (MIN) - Minimum of the angular deviations (degrees).

15. ANGLE (MAX) - Maximum of the angular deviations (degrees).

16. ANGLE (RMS) - Root mean square of the angular deviation fluctuations (degrees).

17. ANGLE (SKEWNESS) - Third moment of the angular deviation fluctuations normalized by the RMS. 
18. ANGLE (FLATNESS) - Fourth moment of the angular deviation fluctuations normalized by the RMS.

At the base of some of these tables is a note stating the magnitude of calibration errors that consistently occurred in the data reduction of all velocity values on that page. In some cases this repeatable error is hypothesized and the word probably has been included; in others the error is def $i$ nitely correctable. In any case the stated values are always within $\pm 3 \%$ of the suggested values. 


\subsection{DISCUSSION}

\subsection{VISUALIZATION RESULTS}

When helium soap bubbles were introduced into flow upwind of the spinning rotor three different phenomena were observed. These were:

1. Most bubbles passed through the spinning rotor and were then caught up in the counterswirling flow downwind of the rotor. That is, the rotor was spinning in a counterclockwise sense and the flow downwind of the rotor swirled in a clockwise sense. This result was expected due to the conservation of angular momentum for this system.

2. When the bubble source was piaced at approximately three-fourths of a radius from the hub, most bubbles seemed to have a straight-line approach to the spinning rotor but approximately $20 \%$ of them were deflected angularly upwind of the rotor. This deflection appeared to be fairly abrupt and occurred around a quarter to half of a rotor radius upwind.

3. When bubbles were caught up into the tip vortices these vortices appear to be quite tight with a bubble making a full revolution in the equivalent distance of approximately one blade length.

The visual result from introducing a smoke source upwind of the rotor was not able to reproduce the detailed flow tagging of helium soap bubbles but it did display the curving of streamlines radially outward around the spinning rotor blades. This is a demonstration of the existence of axial induction effects.

\subsection{WIND FIELD RESULTS}

Figure 4.2-1 displays the mean axial velocities for approach flow case I $\left(U=6.0 \mathrm{~m} / \mathrm{s}, T_{.} \mathrm{I} .=0.1 \%\right)$. The upwind data were obtained at a different time than the downwind data and thus the rotor speeds and calibration biasing may affect precise matching of these data sets. Figure 4.2-1 shows that the axial component of flow approaching the rotor disk was decelerated in the core region, defined by a tube containing the rotor disk, and accelerated outside this region. This deceleration was reasonably uniform with radial position 
up to the measurement location just upwind of the rotor (0.125 rotor diameter). Then it radically departed from this trend as the flow passed through the rotor. An axial induction factor based on mean velocity measurements at 0.125 rotor diameter upwind would be 0.125 but depending on how one extrapolated the data through the rotor section, a radially depended axial induction factor may vary from 0.125 to 0.42 . The flow outside of the rotor tube accelerated as was expected from mass continuity. The ordering of velocity magnitudes with radial distance took an unexplained reversal as the flow passed outside of the rotor blades.

The estimation of axial induction factors based on mean velocity values, as done above, may be in error due to the transient nature of velocity values as the rotor blade passes. The axial velocity just upwind of the rotor varied in a roughly sinusoidal form about its mean value (Figure 4.2-2). For approach flow Case I the periodic variation of axial flow velocity was as large as $\pm 7.5 \%$ of the mean value at 0.125 rotor diameters upwind. If the minimum velocity value were used rather than the mean (File name UU1043, Table 3.3-3) the computed axial induction factor would be 0.2 instead of 0.133 . Thus the transient nature of the flow has a significant influence on values important to the aerodynamic performance of the wind turbine.

Figures 4.2-3a to 4.2-3d display the nomalized mean axial velocity change $100 \times\left(\bar{u}-\bar{u}_{\infty}\right) / \bar{u}_{\infty}$ versus axial distance in rotor diameters for each of the four approach flow conditions. Comparison between plots with similar approach velocities but different turbulence levels (Figures 4.2-3a and 4.2-3c, Figures 4.2-3b and 4.2-3d) do not show any major flow differences in this format. Comparison between plots with similar turbulence levels but different approach velocities (Figures 4.2-3a and 4.2-3b, Figures 4.2-3c and 4.2-3d) displays a difference in the magnitude of the range of mean axial velocities in the wake region of the turbine only. The range of axial velocity variation was greatest in the lower approach wind speed cases.

Figure 4.2-4 displays the normalized mean radial velocity $\left(100 \times \bar{u}_{r} / \bar{u}_{x}\right)$ versus axial distance in rotor diameters for approach flow Case II. It shows that the flow was divergent approaching the wind turbine and in the wake region . out to at least half a rotor diameter downwind. The maximum divergence was at the rotor disk where the mean velocity vector deviated by $10^{\circ}$ from that of 
the approach flow. The radial velocities were greatest (14 to $20 \%$ of the approach velocity value) near the tip region. The radial velocity transient variation just upwind of the disk and downwind outside of the rotor wake was nearly sinusoidal in form as observed by a flatness factor near to 1.5 .

Figure 4.2-5 displays the normalized mean angular velocity $(100 \times$ $\left.\bar{u}_{\theta} /\left(\bar{u}_{x}\right)_{\infty}\right)$ versus axial distance in rotor diameters. Within the wake region large negative angular velocities exist (the rotor was spinning in the positive sense). The magnitude of these angular velocities was greatest $(\approx 25 \%$ of the approach flow velocity) at the innermost radial measurement position of oneeighth rotor diameter. The flow inmediately upwind of the rotor and the flow downwind of the rotor but outside of its wake have negative mean angular velocities but their magnitude ( $\simeq 2-3 \%$ of the approach flow velocity) is much less than that in the wake region.

Classical vortex/strip theory assumes that the angular velocity at the rotor disk is half of the angular velocity imparted to the slip stream (Wilson et al. 1976). This assumption leads to the use of an angular induction factor, $a^{\prime}$, to correct the blade section angle of attack for induced rotational motions. These corrections usually presume a rotating activator disk with an infinite number of blades.

To compute the instantaneous angular induction factor for the model wind turbine, a correlation between the rotor blade positions and the angular velocity components' magnitude must be known. Unfortunately, a blade position time series was not measured during this study. Examination of the axial and angular velocity time series (Run No. 1043) presented in Figures 4.2-2 and 4.2-6 can give a qualitative estimate as to the sign of the angular induction factor. The sharp drop seen in the axial velocity time series is undoubtedly due to the pressure field surrounding a passing rotor blade. This fall in axial velocity occurs at the same time as a sharp maximum in the angular velocity time series. This would indicate that the rotor blade sees an angular velocity component that is in the opposite direction as the rotor blade travel.

Figures 4.2-2 and 4.2-6 also show that each rotor blade has a different periodic magnitude. This was due to slight misalignments of the rotor blades in their plane of motion. One rotor blade was $3 \mathrm{~mm}$ closer to the measurement 
probe than the other. Since the probe was 67 man from the rotor plane the flow characteristics must be changing rapidiy in the immediate region in front of the rotor disk.

Figures 4.2-7a and 4.2-7b display the axial turbulent intensity relative to the free strean wind speed $\left(100 \times u^{\prime} \mathrm{rms} / \bar{u}_{\infty}\right)$ versus axial distance in rotor diameters for approach flow Cases II and IV respectively. They show that the axial turbulence energy increases dramatically in the region approaching the rotor disk and then initially decreases sharply in the rotor wake. The sharp increase in turbulent intensity for the spatial location of $X=1 / 2, R=1 / 8$ is due to the influence of the growing wake caused by the wind turbine hub and support mechanism. Figure 4.2-8 of the axial flatness factor versus axial distance shows that most of this turbulent intensity in the non-wake region is due to an organized periodic structure of slowly varying amplitudes, approaching that of a sine wave.

The velocity time series for the axjal velocity component (Figure 4.2-2) and the angular velocity component (Figure 4.2-6) help estimate the angle of attack(a) during a rotor cycle. The rotor rotational velocity, 25.81 rps, was estimated by measuring the time period between blade passages on these figures. At a radius of $0.201 \mathrm{~m}$ the velocity of this rotor blade section was $32.6 \mathrm{~m} / \mathrm{s}$. This information was used to plot the angle of attack time series shown in Figure 4.2-9. This figure shows that the periodic nature of axial induction is the primary cause for variations in the angle of attack for this approach flow and position. The actual variation of angle of attack that occurs at the rotor disk will be larger than that shown here at 6.7 cin upwind of the rotor disk.

(a) No account has been made for rotor blade twist angle. 


\subsection{REFERENCES}

Baker, R. W., and S. N. Walker. 1982. Wake Studies at the Goodnoe Hills Mod-2 Site. DOE/BP-182, Bonneville Power Administration, Portland, Oregon.

Bushnel1, P. 1984. Design of Rotor Blades for a Model Horizontal Axis Wind Turbine. Cornell University, Ithaca, New York.

Bushne11, P. 1983. Experimental Study of the Vortex Wake Formed by a Model Wind Turbine. Cornell University, Ithaca, New York.

Cliff, W. C., and G. H. Ficht1. 1978. Wind Velocity-Change (Gust Rise) Criteria for Wind Turbine Design. PNL-2526, Pacific Northwest Laboratory, Richland, Washington.

Eberle, W. R. 1981. Wind Flow Characteristics in the Wakes of Large Wind Turbines, pp. 1-211. DOE/NASA0029-1, Lockheed Missiles and Space Company, Inc., Sunnyvale, California.

Ficht 1, G. 1983. Covariance Statistics of Turbulence Velocity Components for Wind Energy Conversion System Design-Homogeneous, Isotropic Case. PNL-3499, Pacific Northwest Laboratory, Richland, Washington.

Hansen, A. C. 1979. "Effects of Turbulence on Wind Turbine Performance." ASCE Preprint 3537, pp. 1-17.

Kareen, A. 1981. "Wind-Loading Definition for the Structural Design of Wind-Turbine Generators." Journal of Energy 5(2):89-93.

Plate, E. J., and J. E. Cermak. 1963. Micrometeorological Wind Tunnel Facility: Description and Characteristics. CER63-EJP-JEC-9, Colorado State University, Fort Collins, Colorado.

Riley, J. J., E. W. Geller, M. D. Coon and J. C. Schedvin. 1980. A Review of Wind Turbine Wake Effects. DOE/ET/23160-80/1. Available from National Technical Information Service, Springfield, Virginia.

TSI Technical Bulletin No. 8. No Date. "Date Reduction Method for Model 1294 3-D Probes, Orthogonal Sensors." TSI, Inc., St. Paul, Minnesota.

Wilson, R. E., P. B. S. Lissaman and S. N. Walker. 1976. Aerodynamic Performance of Wind Turbines, p. 164. Oregon State University, Corvallis, Oregon. 
FIGURES 


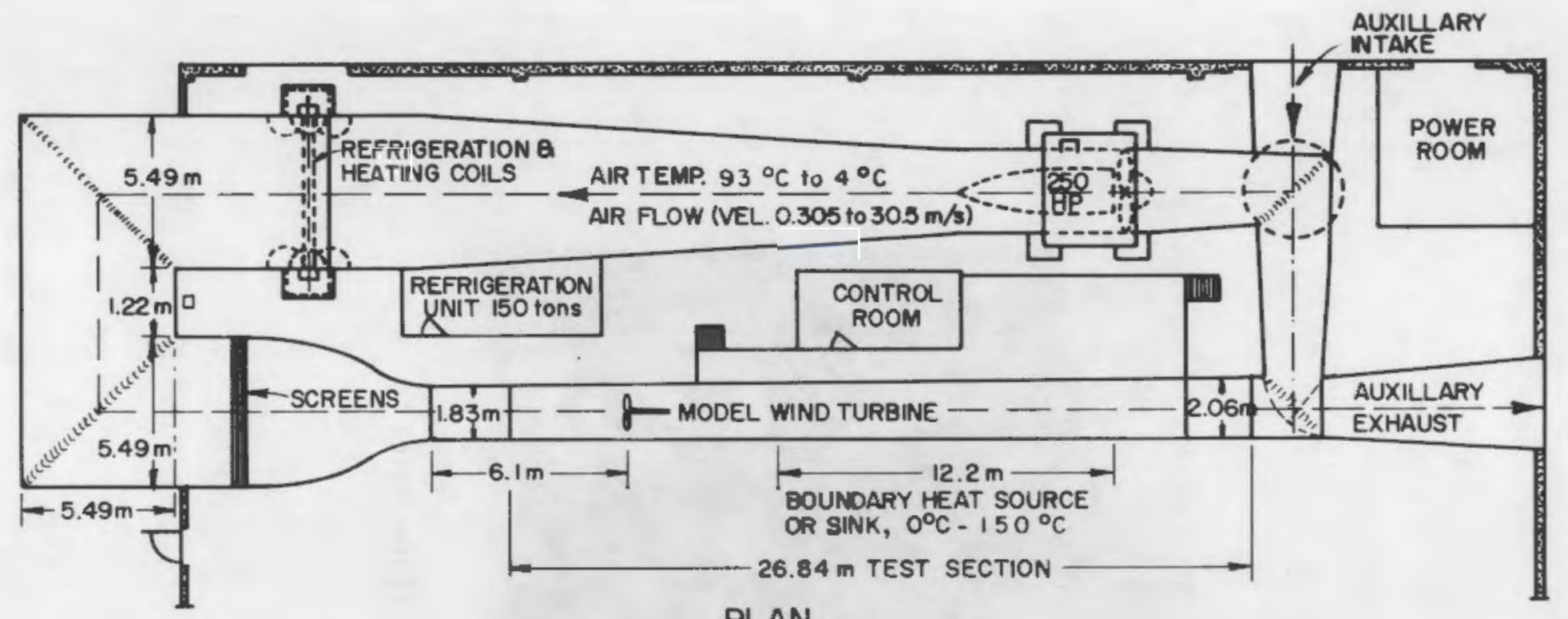

ज

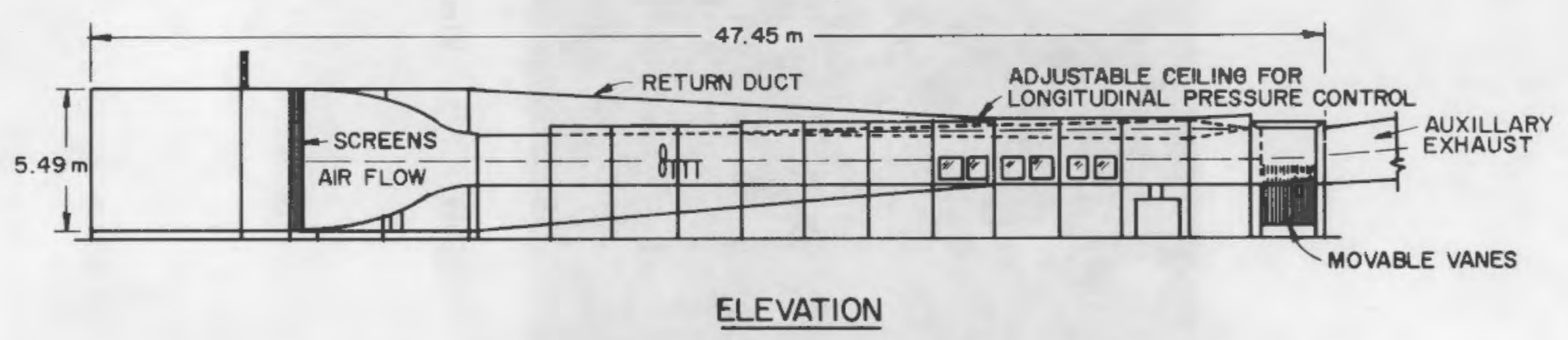

FIGURE 2.1-1. Meteorological Wind Tunnel 


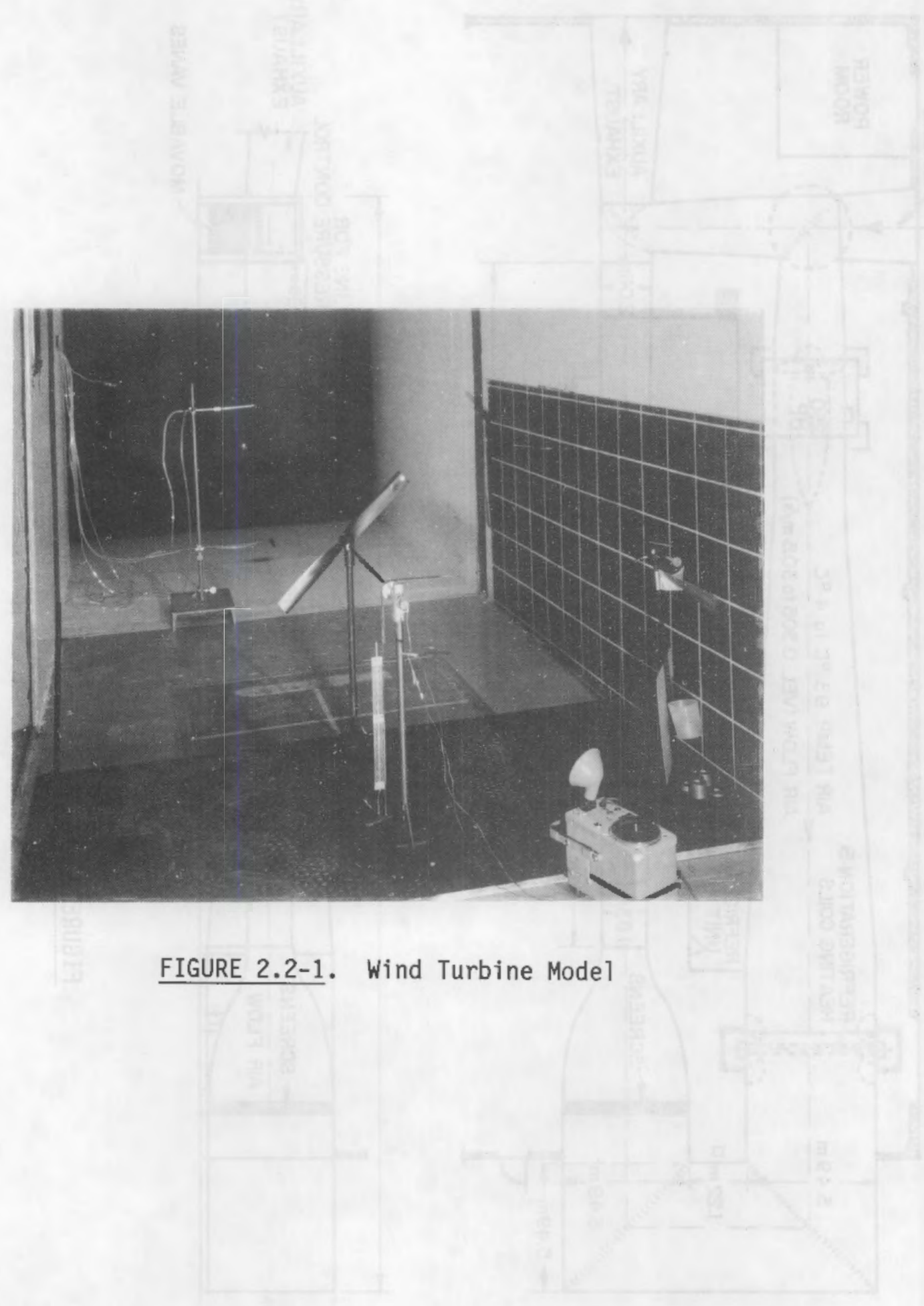




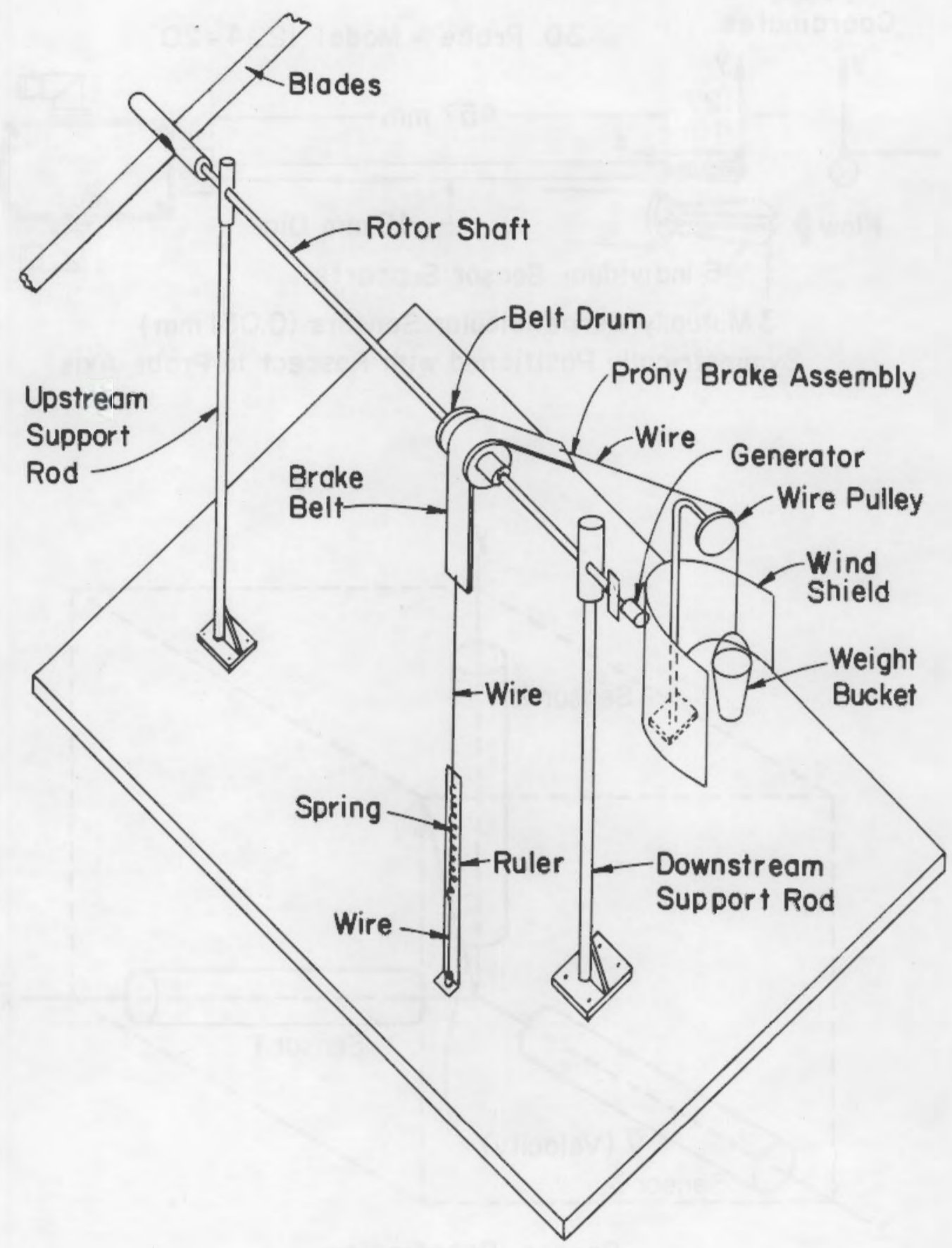

FIGURE 2.2-2. Wind Turbine Mounting Diagram 

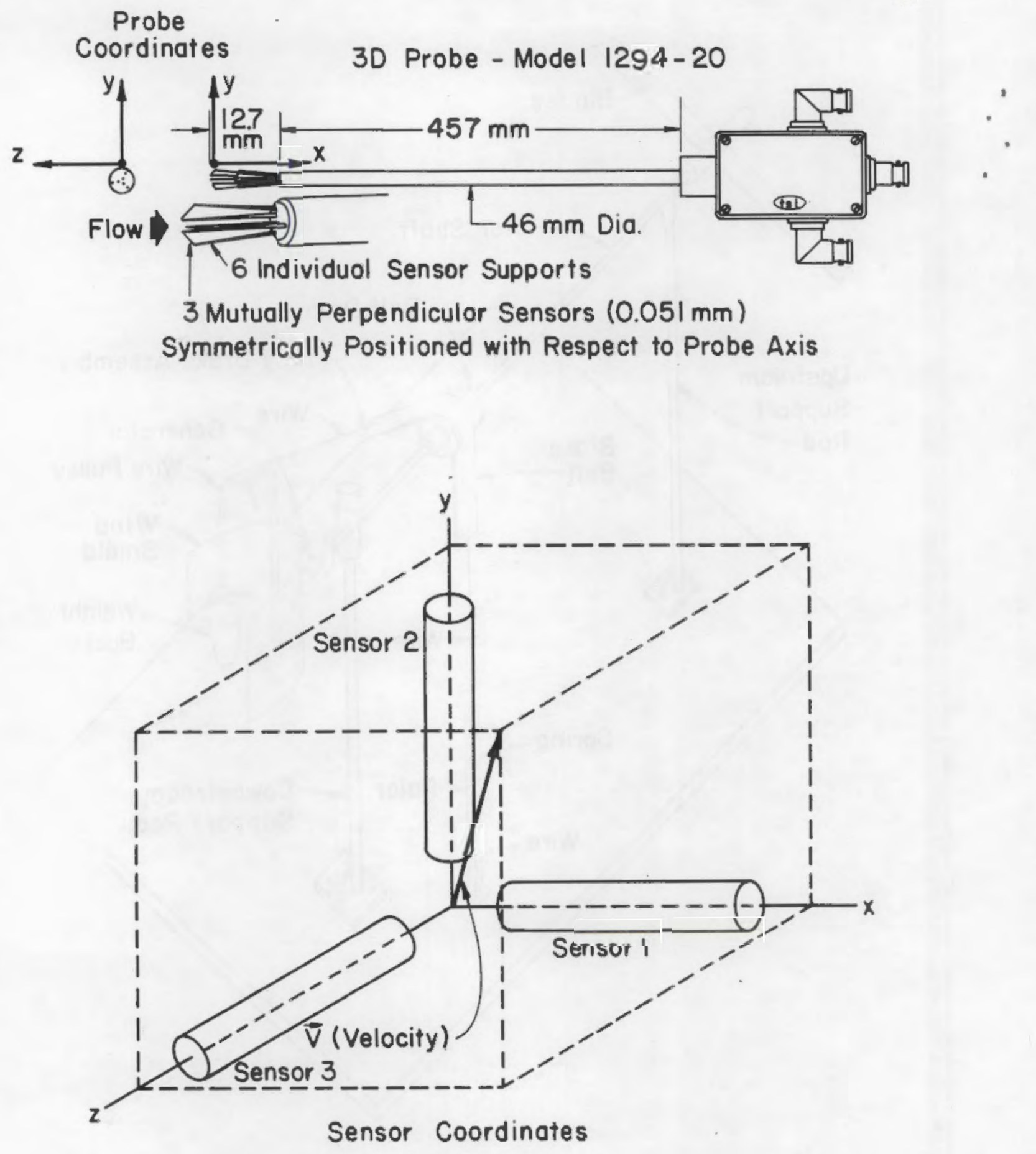

FIGURE 2.4.4-1. TSI Model 1294-20 3-D Probe 


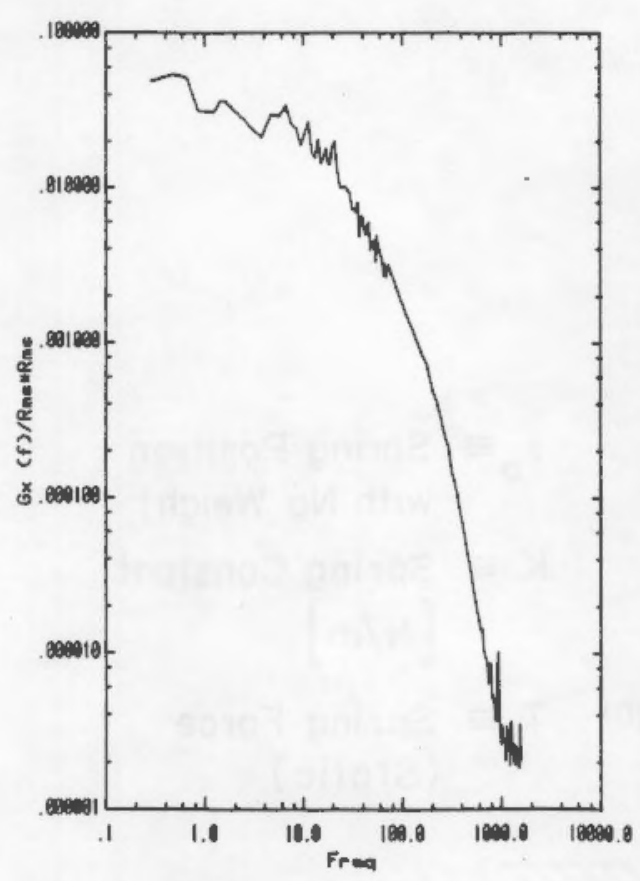

Single Film

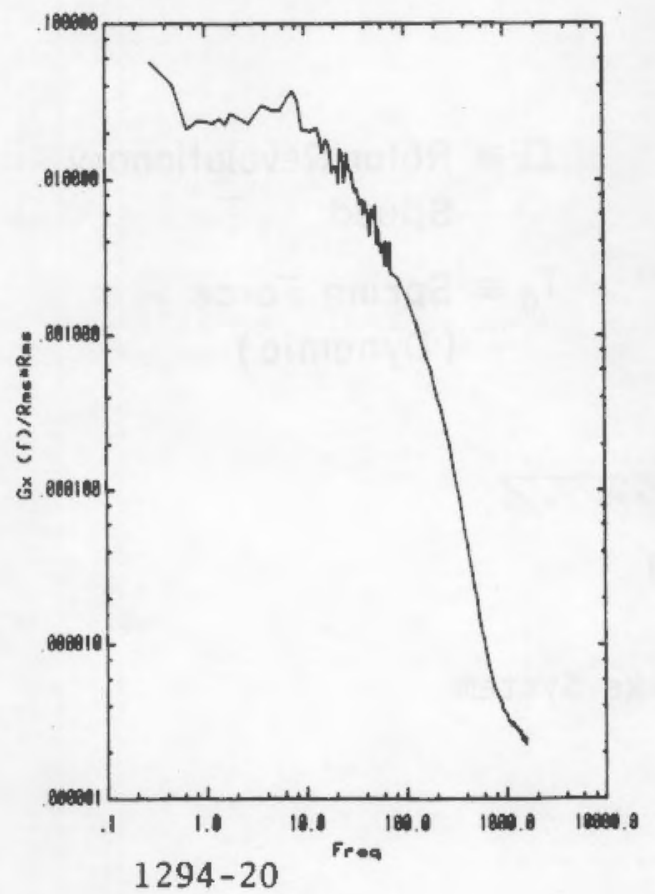

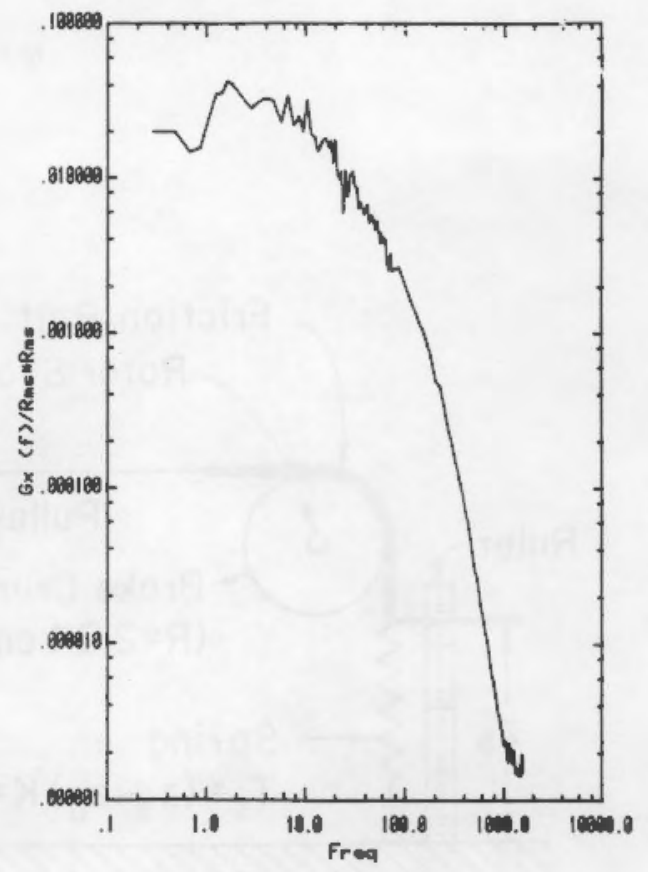

Cross Film

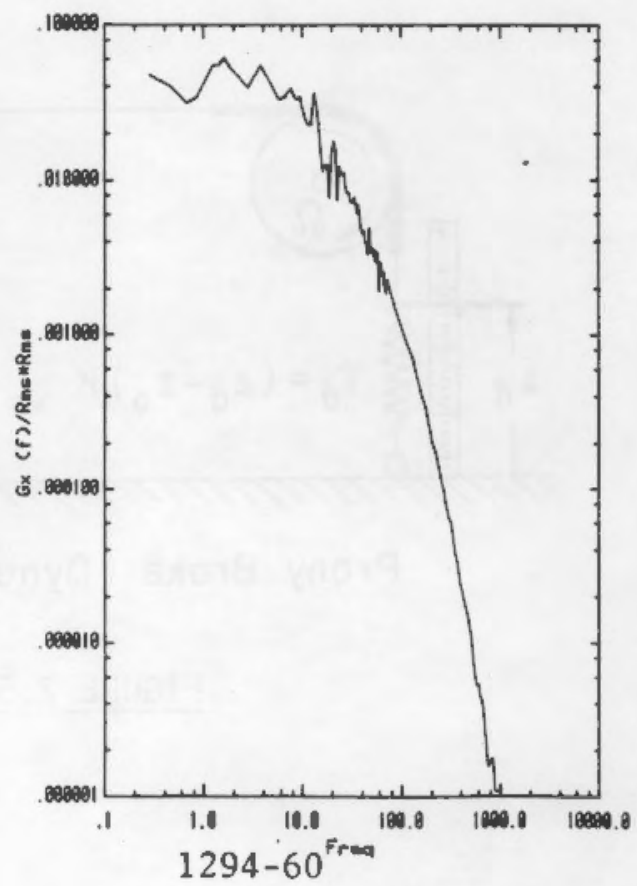

FIGURE 2.4.4-2. Spectral Response of Different Anemometer Probes 


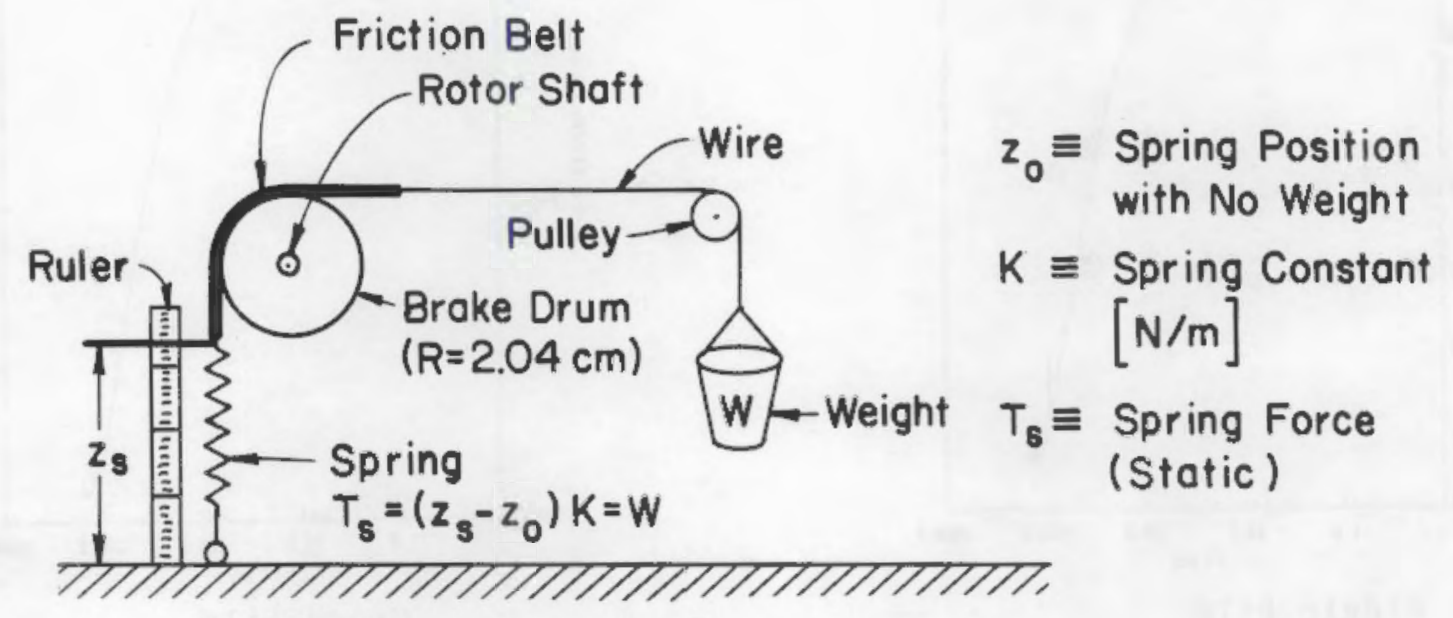

Prany Brake (Static Position)

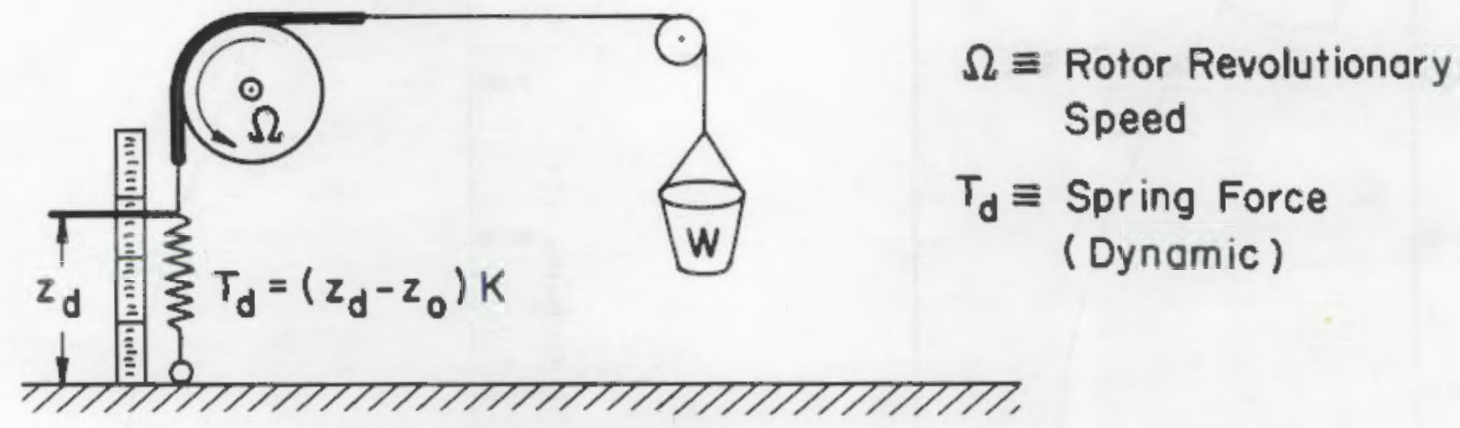

Prony Brake (Dynamic Position)

FIGURE 2.5-1. Prony Brake System 


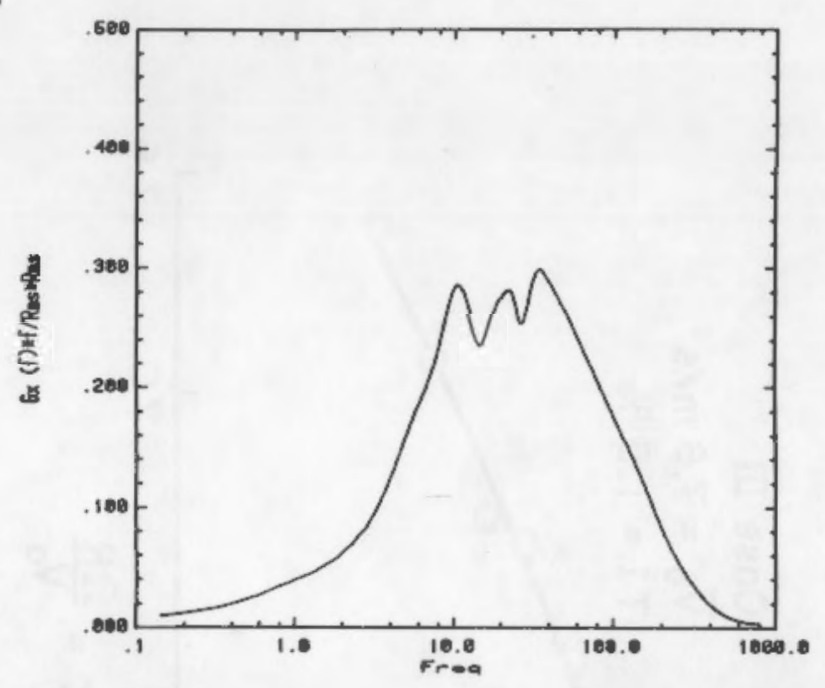

U Component

Flow No. 3

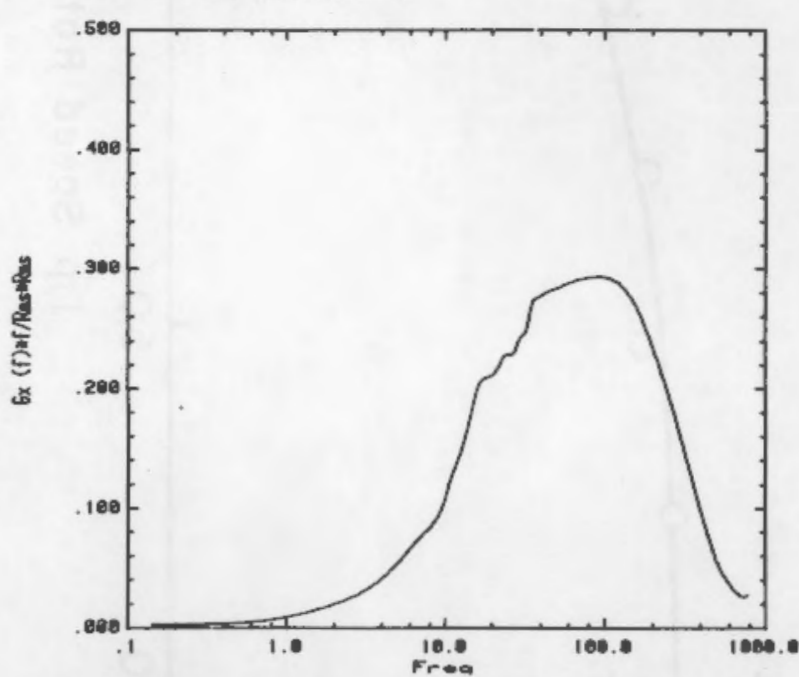

$W$ Component

Flow No. 3

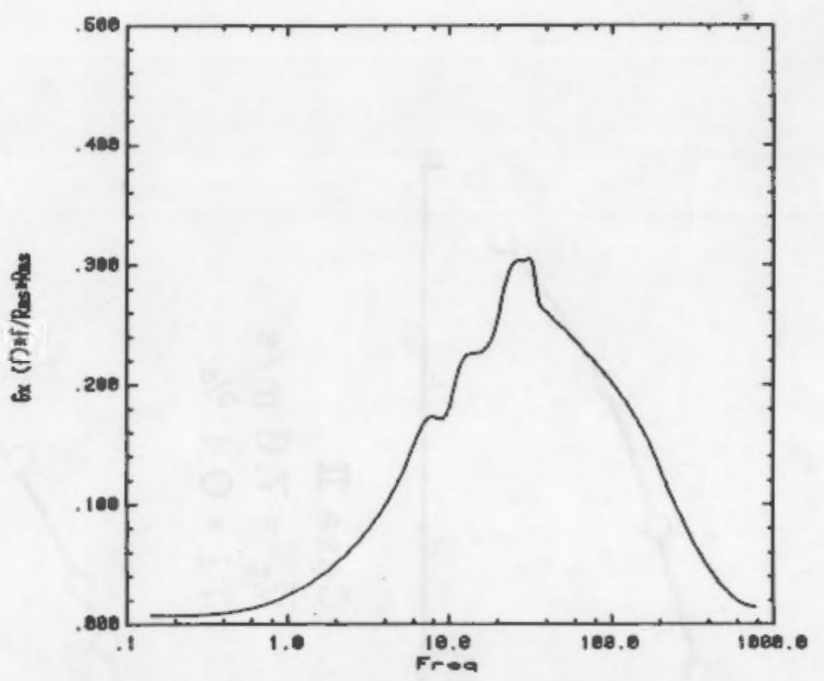

U Component

Flow No: 4

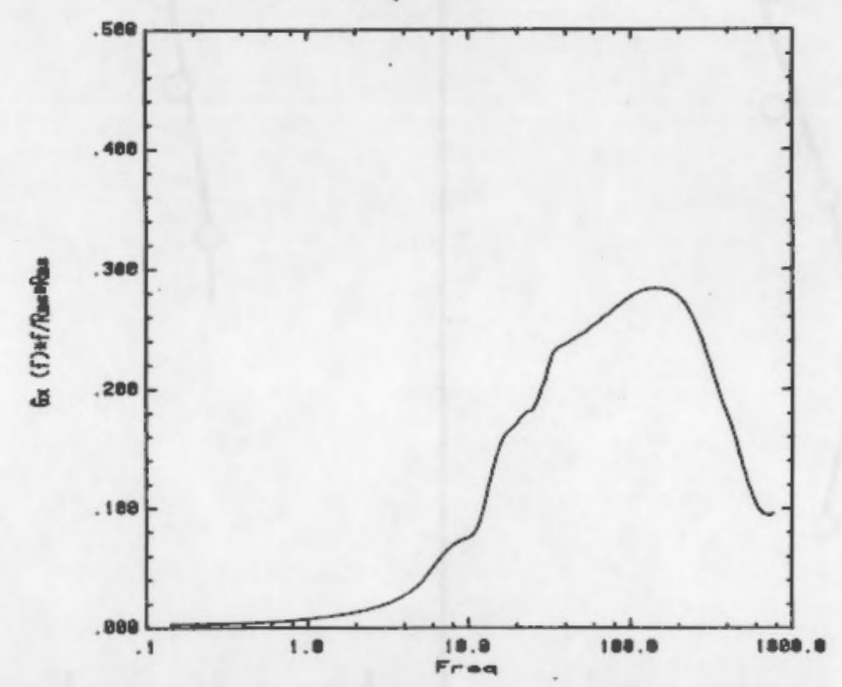

W Component

Flow No. 4

FIGURE 3.1-1. Velocity Fluctuation Power Spectrums for Approach Flows 3 and 4 


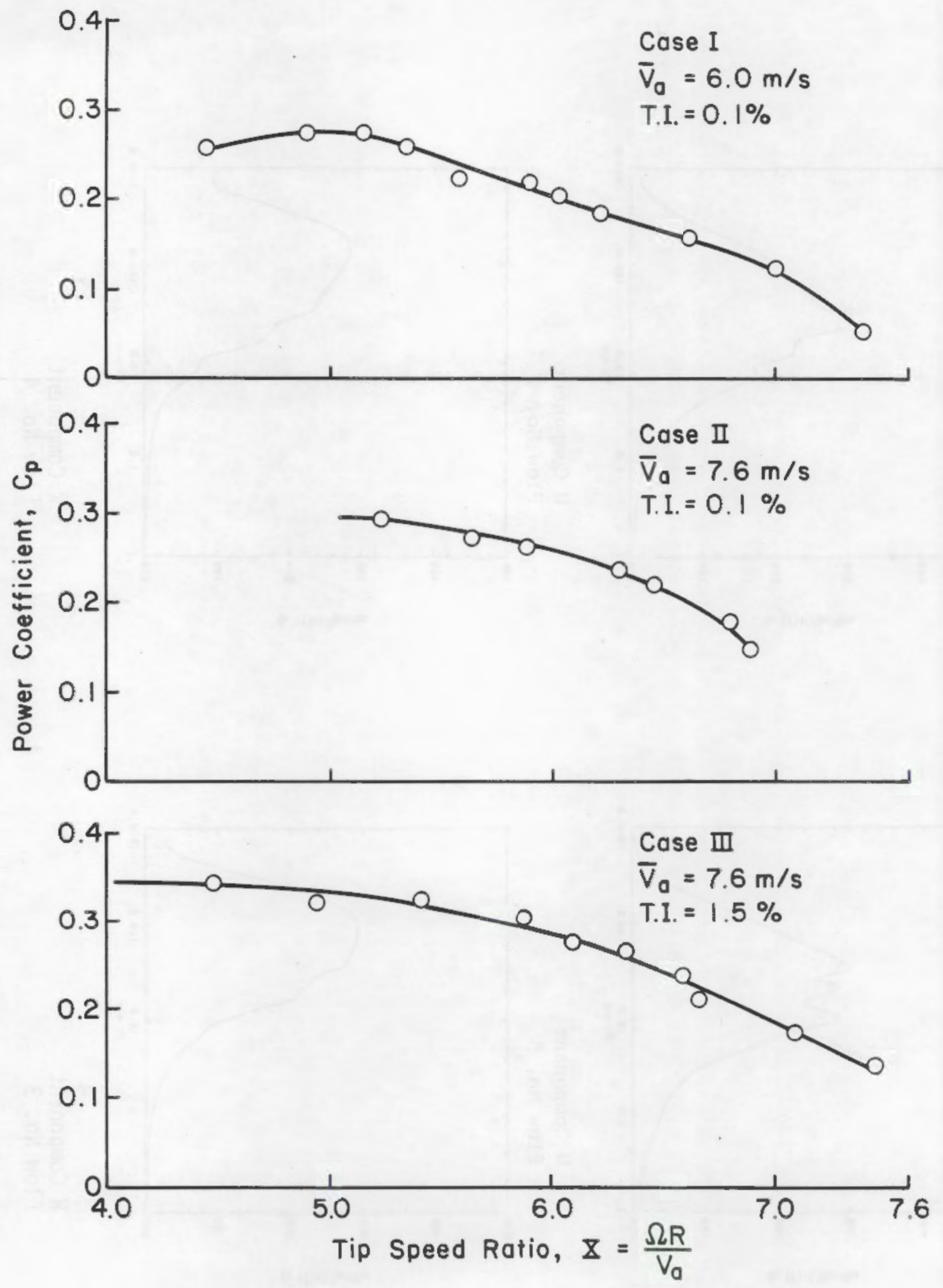

FIGURE 3.2-1. Power Coefficient Versus Tip Speed Ratio 


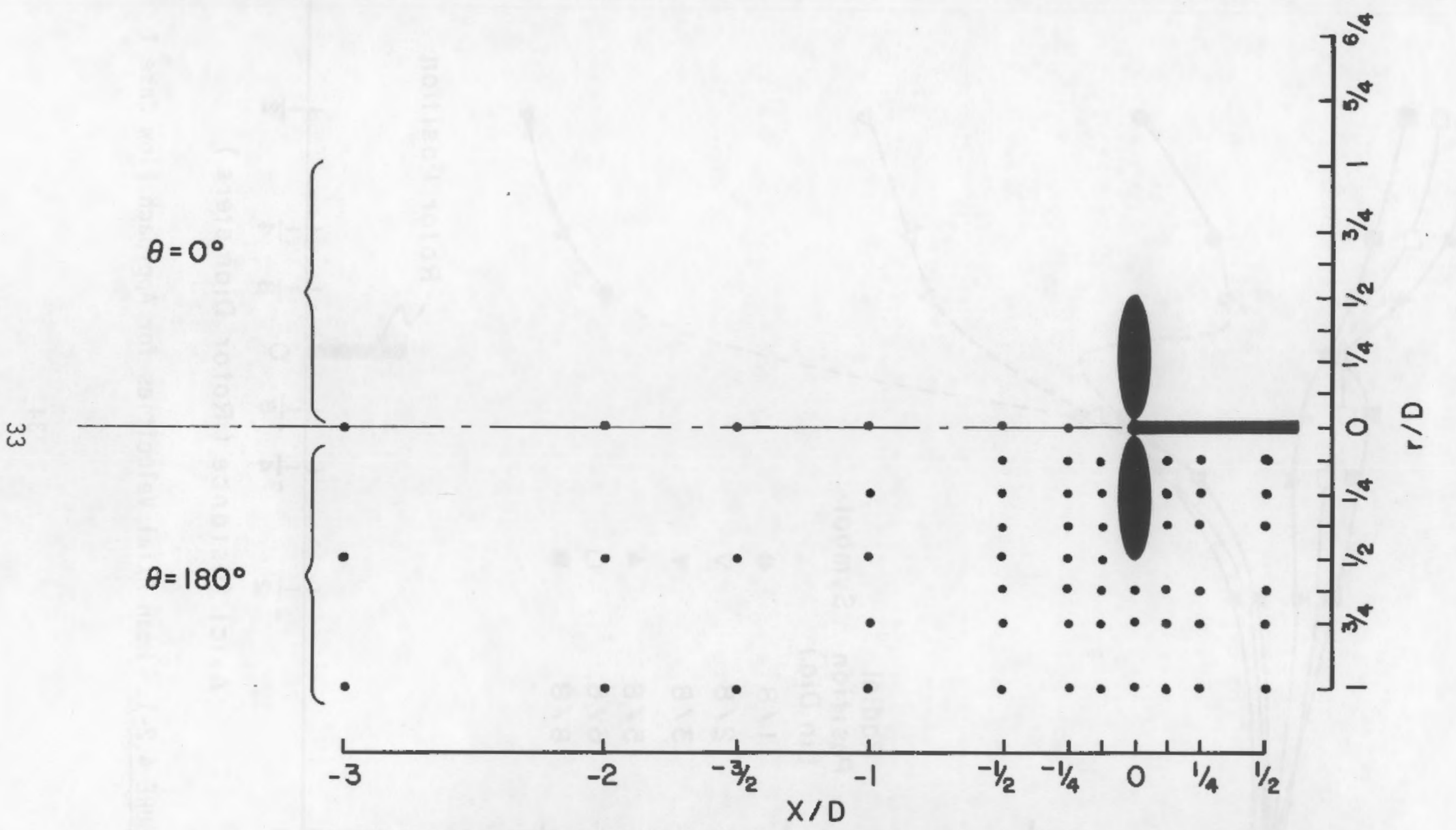

FIGURE 3.3-1. Measurement Locations. Note that measurements downwind were taken only away from the tip vortex region where flow might pass through other directions than the one for which the velocity probe is oriented. See Column 4, Table 3.3-3 for estimate of this end. 


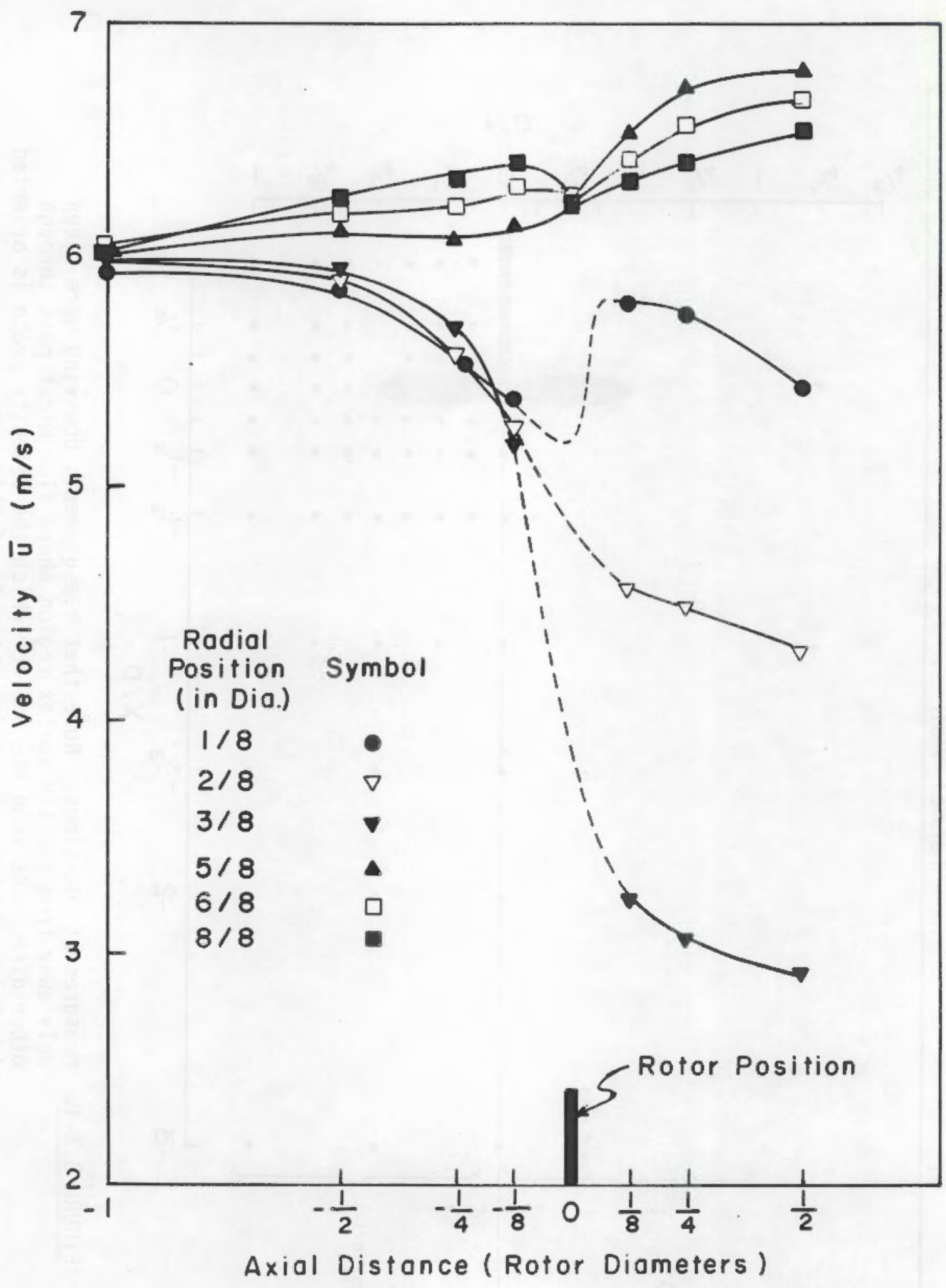

FIGURE 4.2-1. Mean Axial Velocities for Approach Flow Case I 


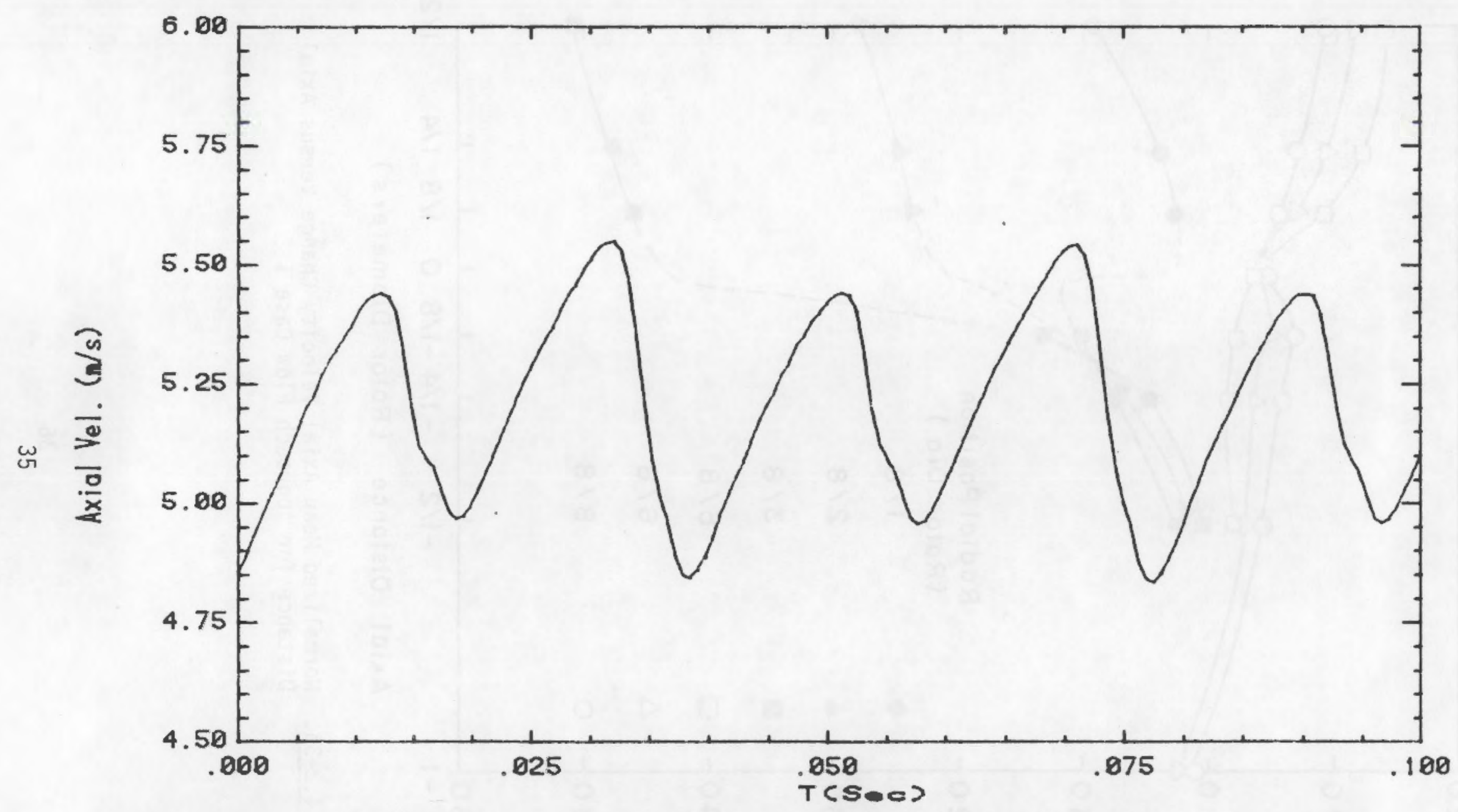

FIGURE 4.2-2. Axial Velocity Time Series for Run No. 1043, Just Upwind of Rotor Plane 


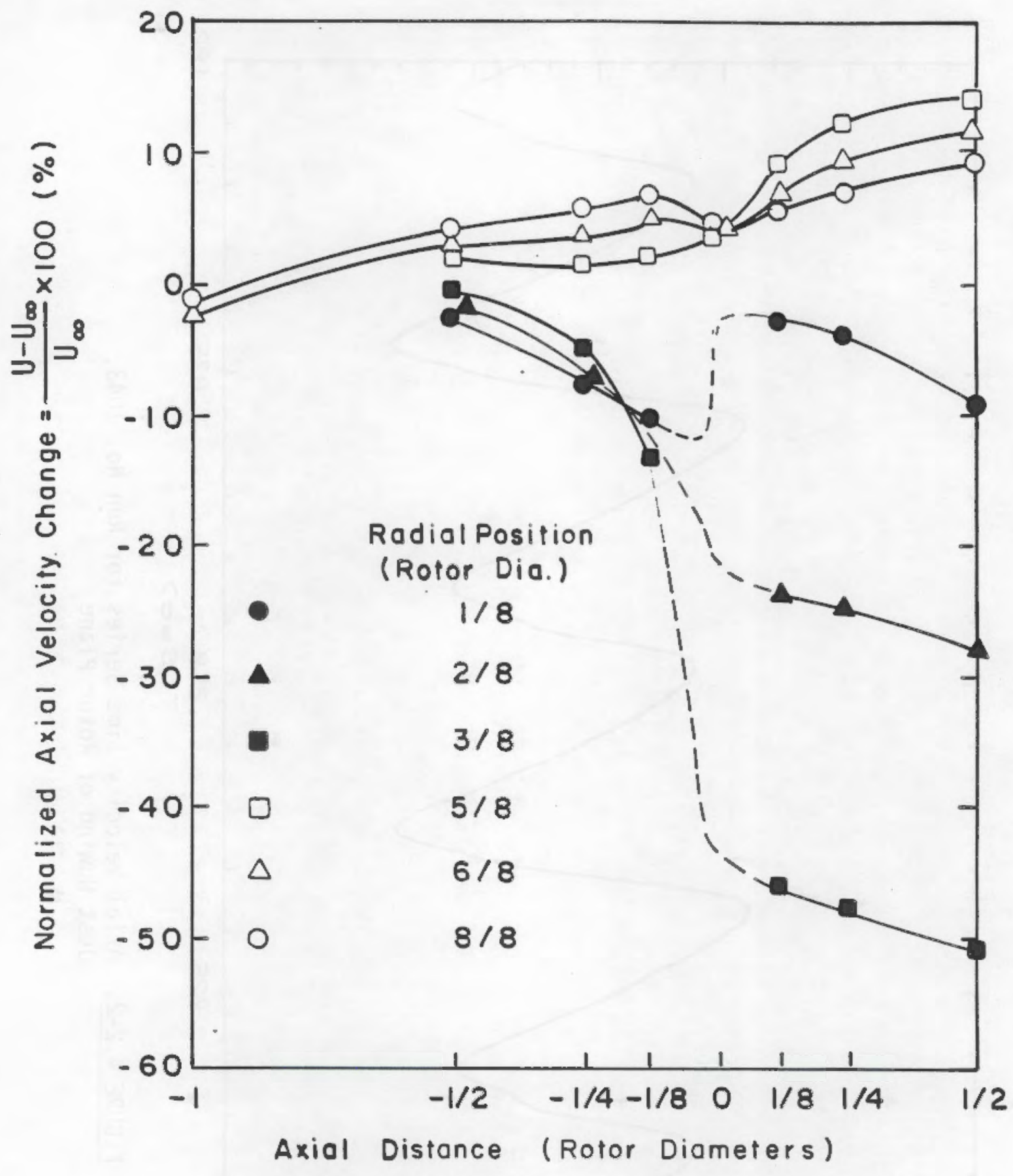

FIGURE 4.2-3a. Normalized Mean Axial Velocity Change Versus Axial Distance for Approach Flow Case I 


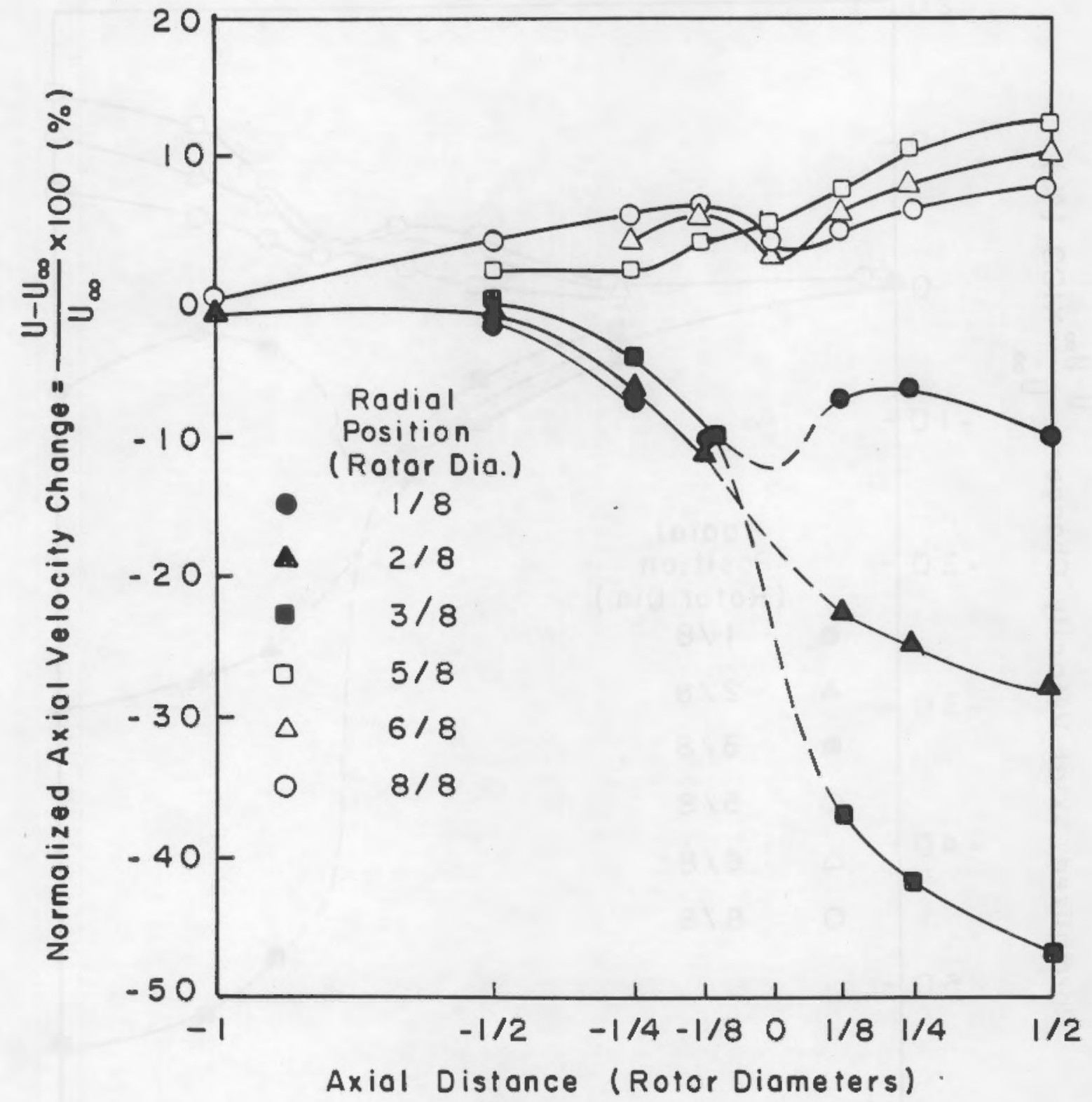

FIGURE 4.2-3b. Normalized Mean Axial. Velocity Change Versus Axial Distance for Approach Flow Case II 


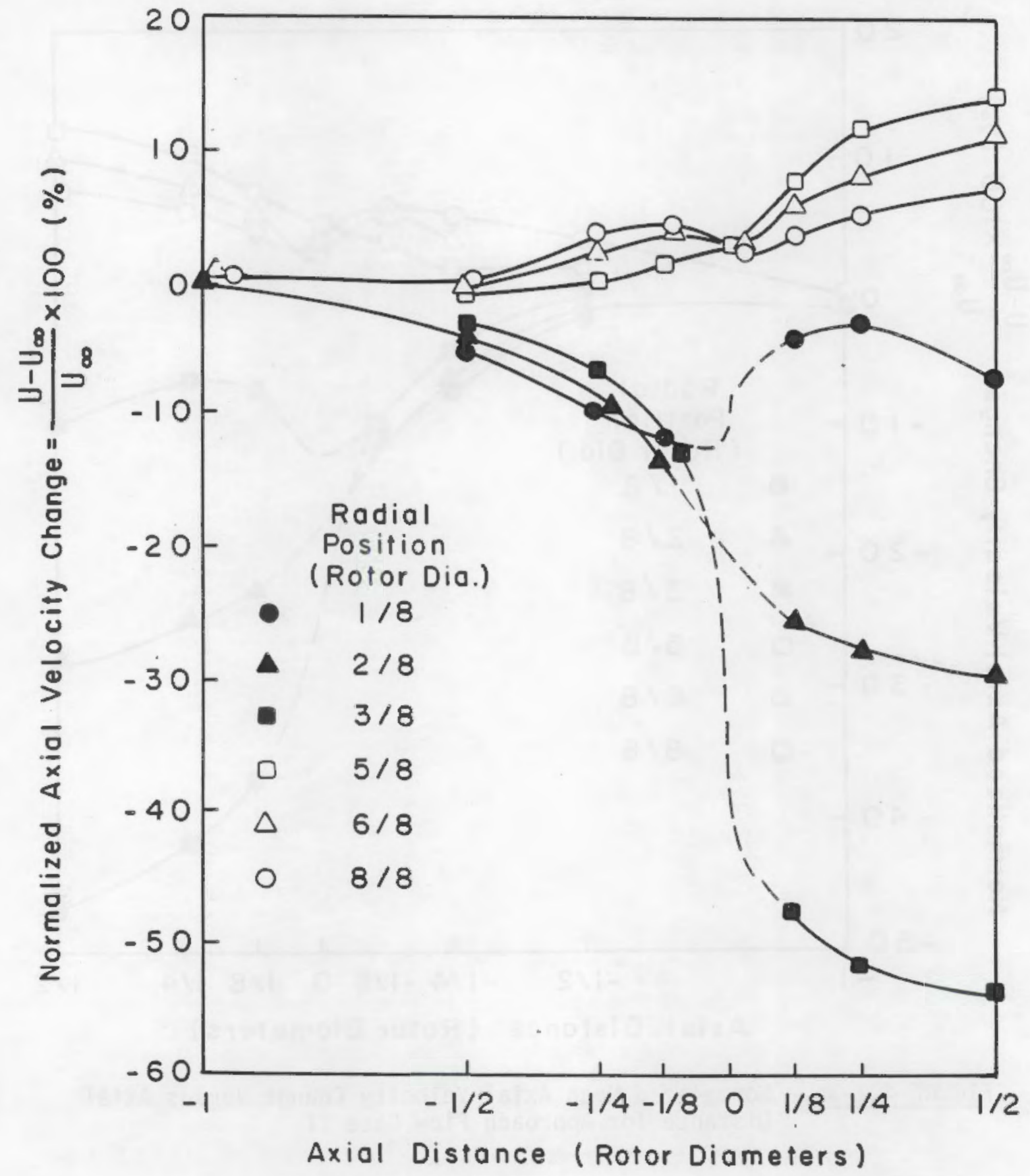

FIGURE 4.2-3c. Normalized Mean Axial Velocity Change Versus Axial Distance for Approach Flow Case III 


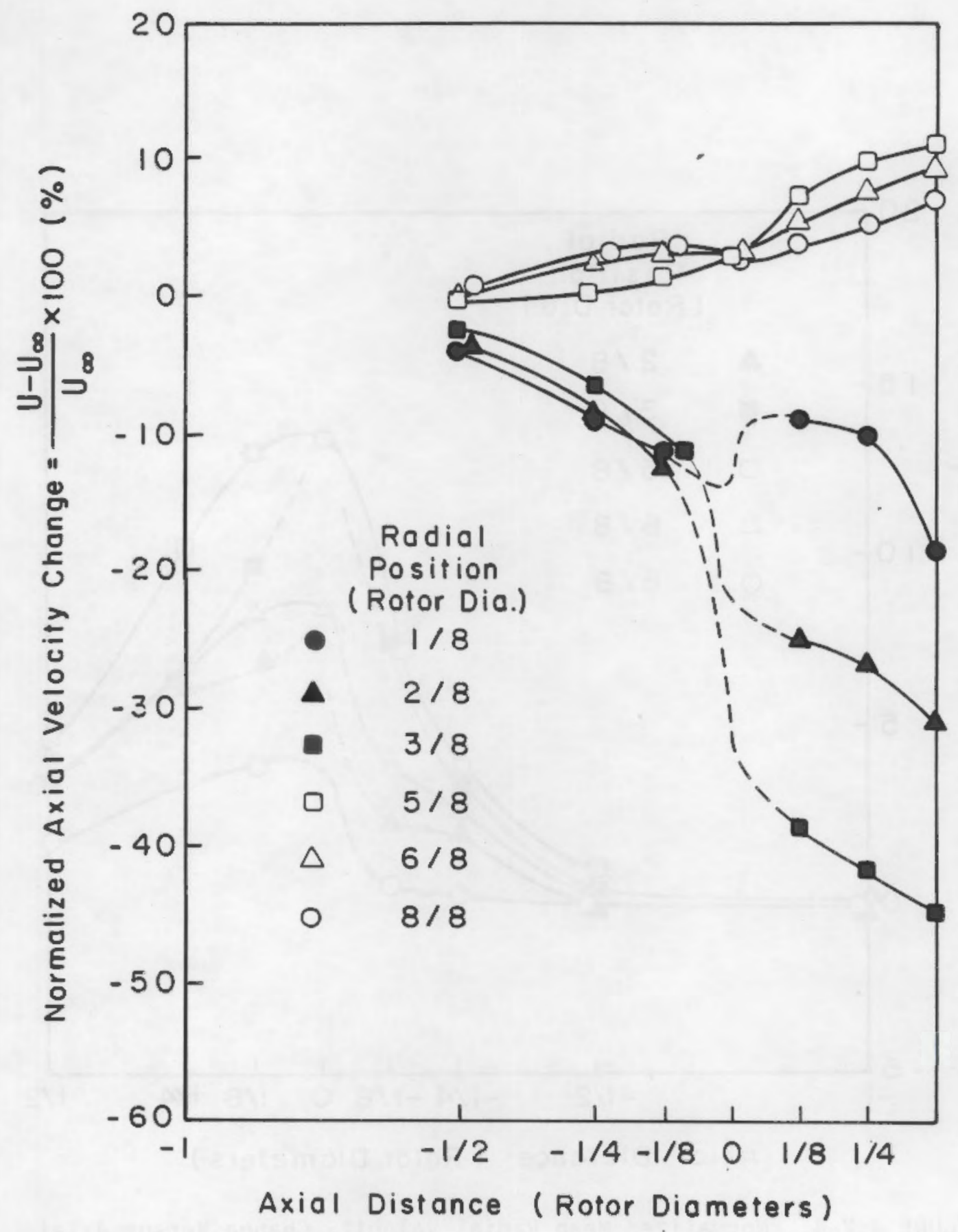

FIGURE 4.2-3d. Normalized Mean Axial Velocity Change Versus Axial Distance for Approach Flow Case IV 


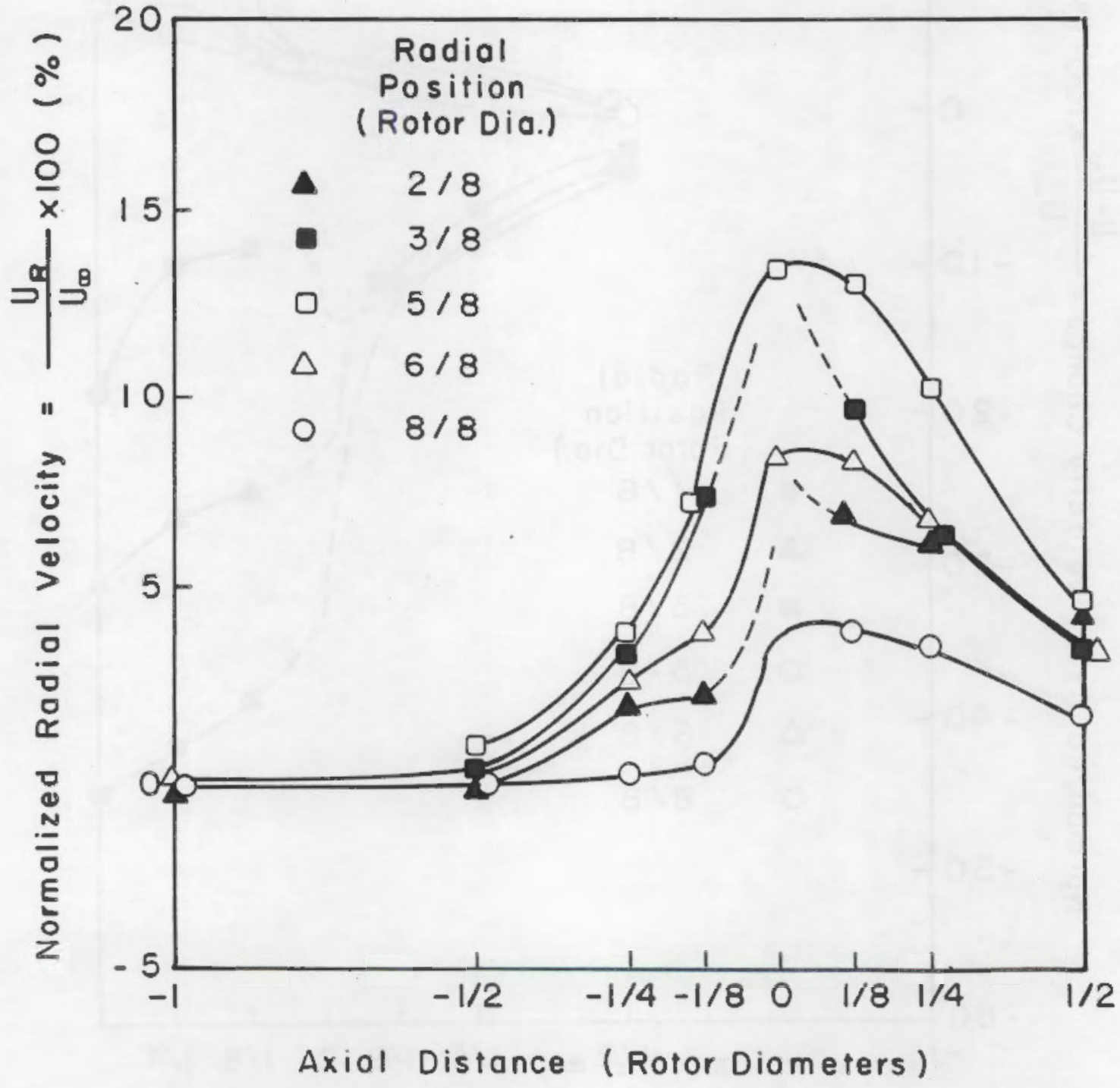

FIGURE 4.2-4. Normalized Mean Radial Velocity Change Versus Axial Distance for Approach Flow Case II 


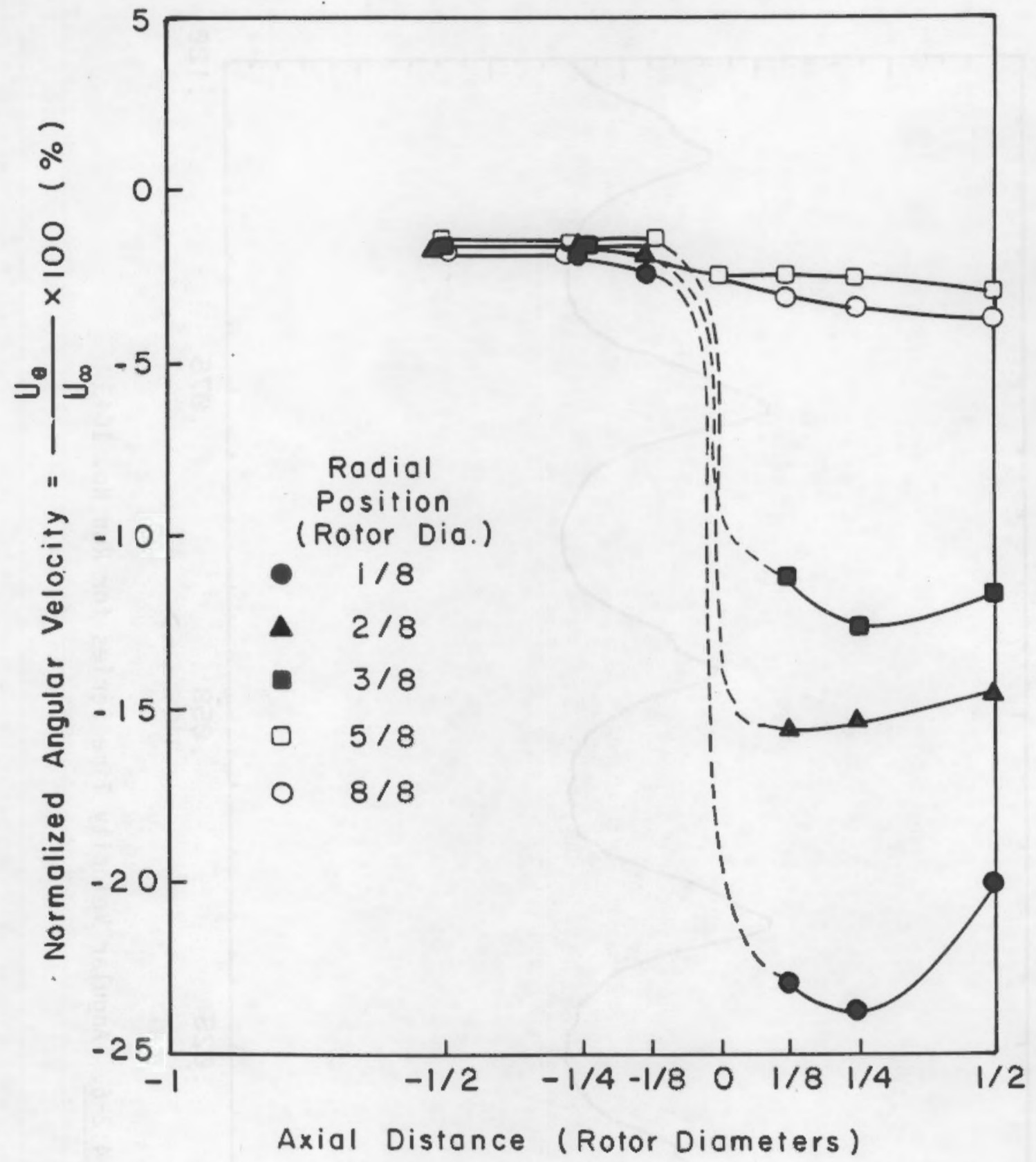

FIGURE 4.2-5. Normalized Mean Angular Velocity Change Versus Axial Distance for Approach Flow Case II 


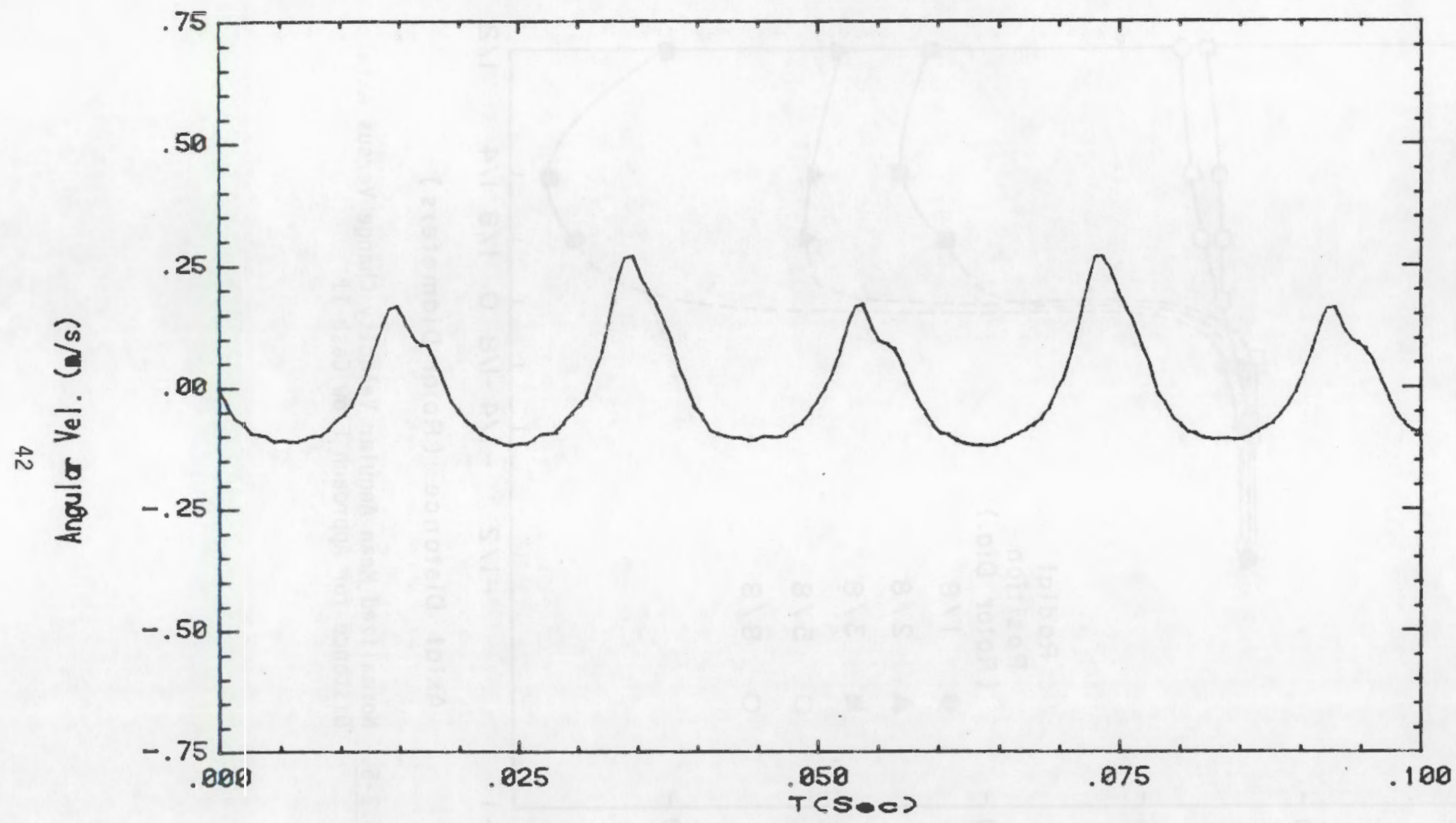

FIGURE 4.2-6. Angular Velocity Time Series for Run No. 1043 


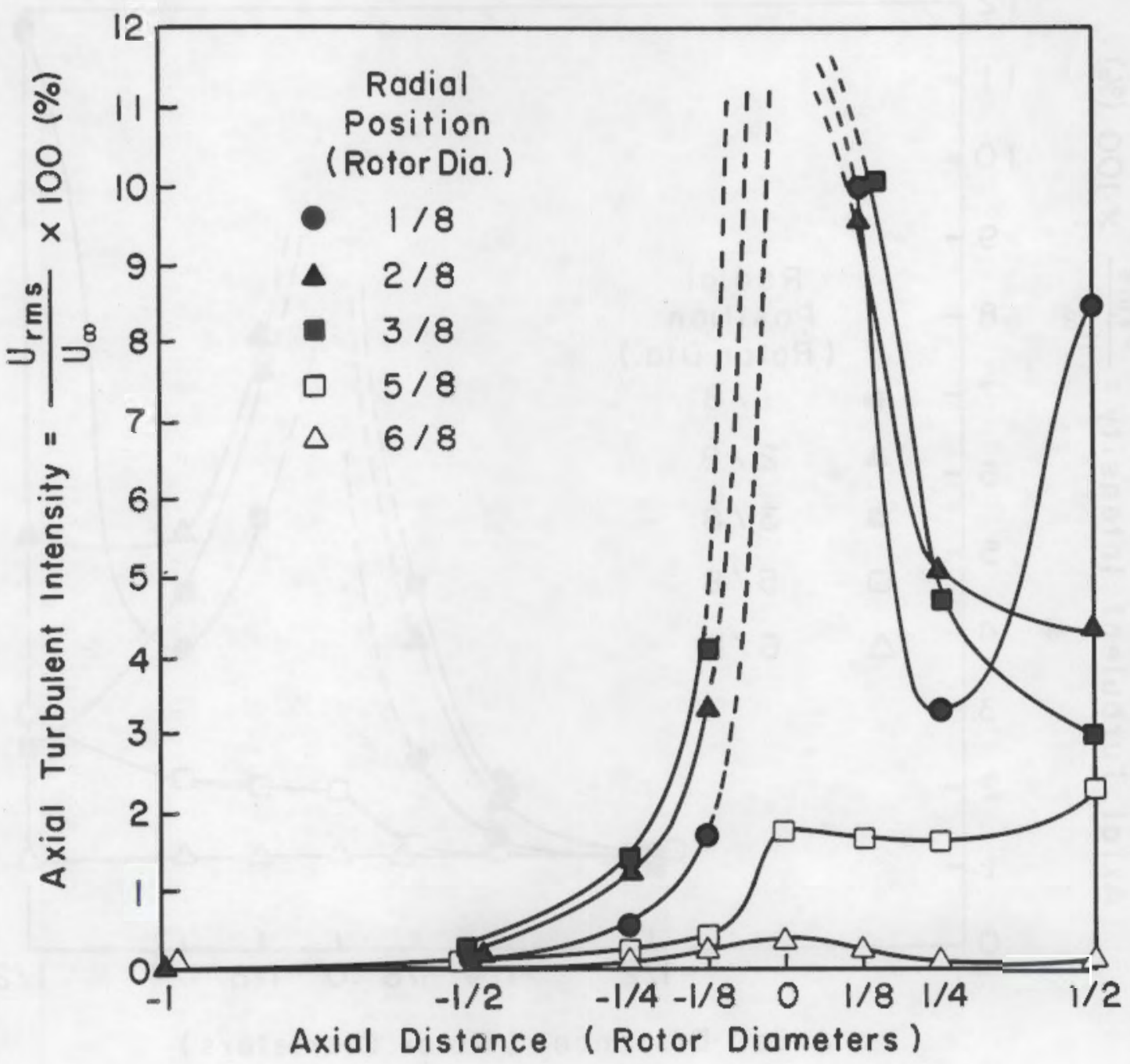

FIGURE 4.2-7a. Axial Turbulent Intensity Versus Axial Distance for Approach Flow Case II 


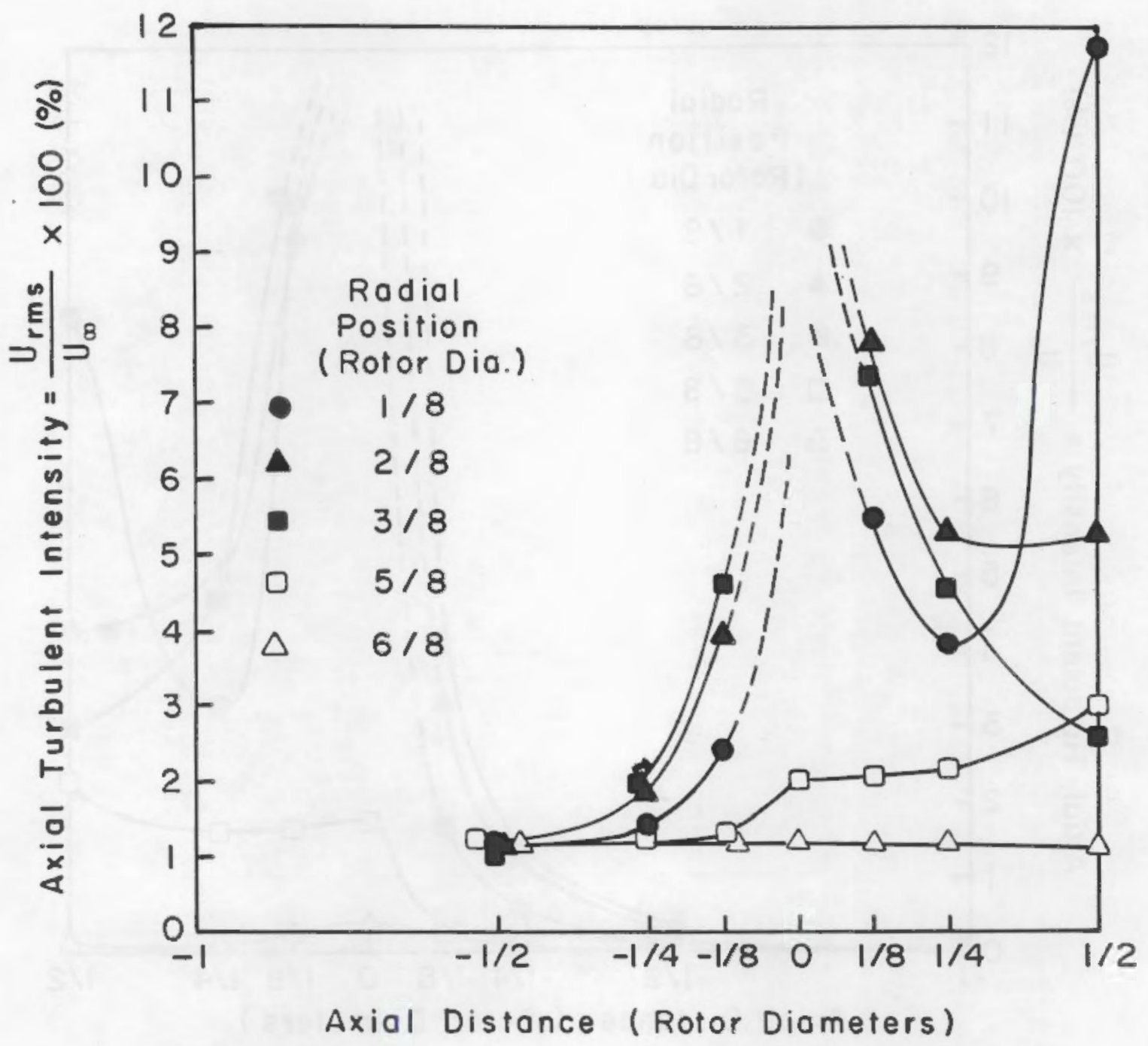

FIGURE 4.2-7b. Axial Turbulent Intensity Versus Axial Distance for Approach Flow Case IV 


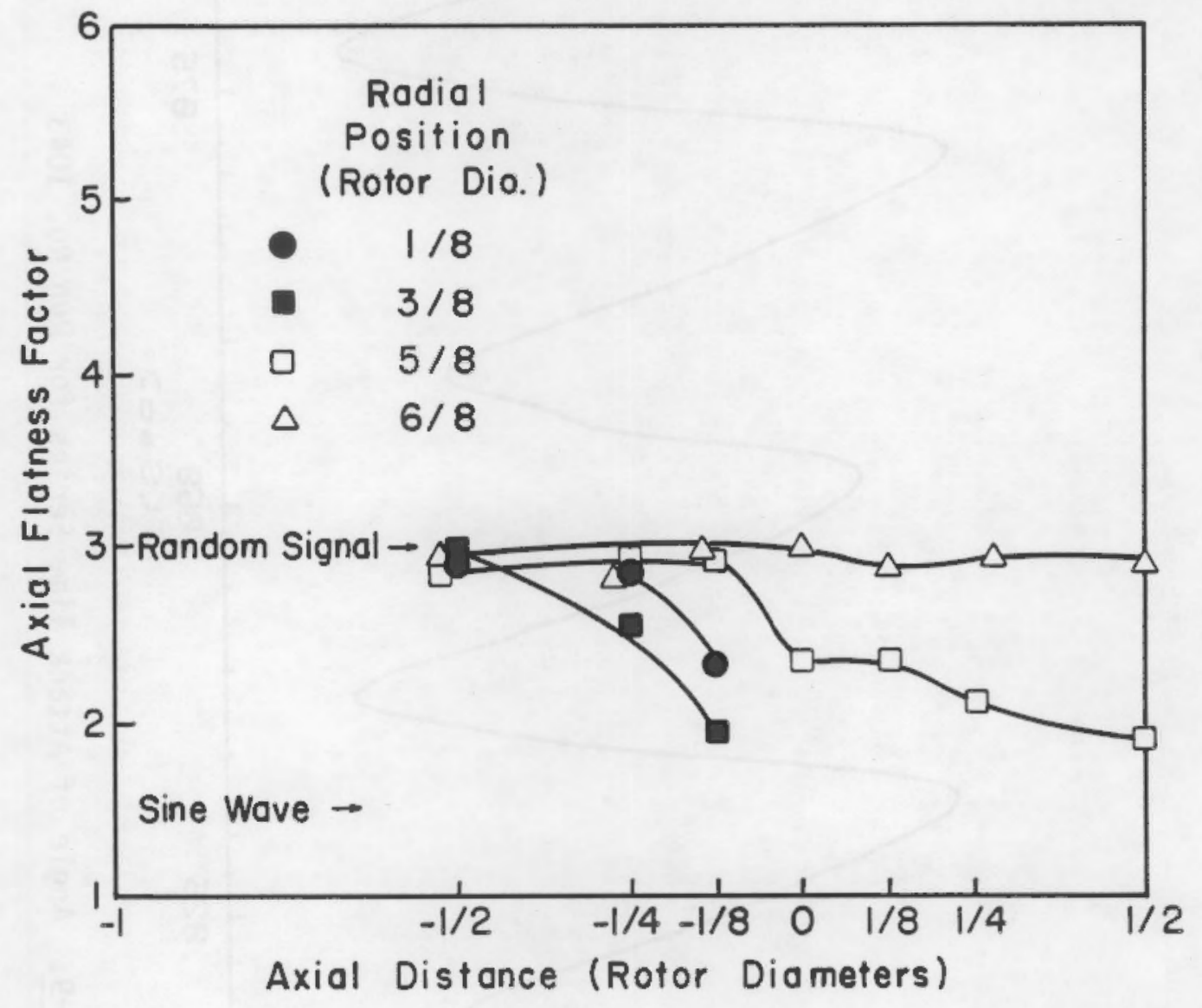

FIGURE 4.2-8. Axial Flatness Factor Versus Axial Distance for Approach Flow Case IV 


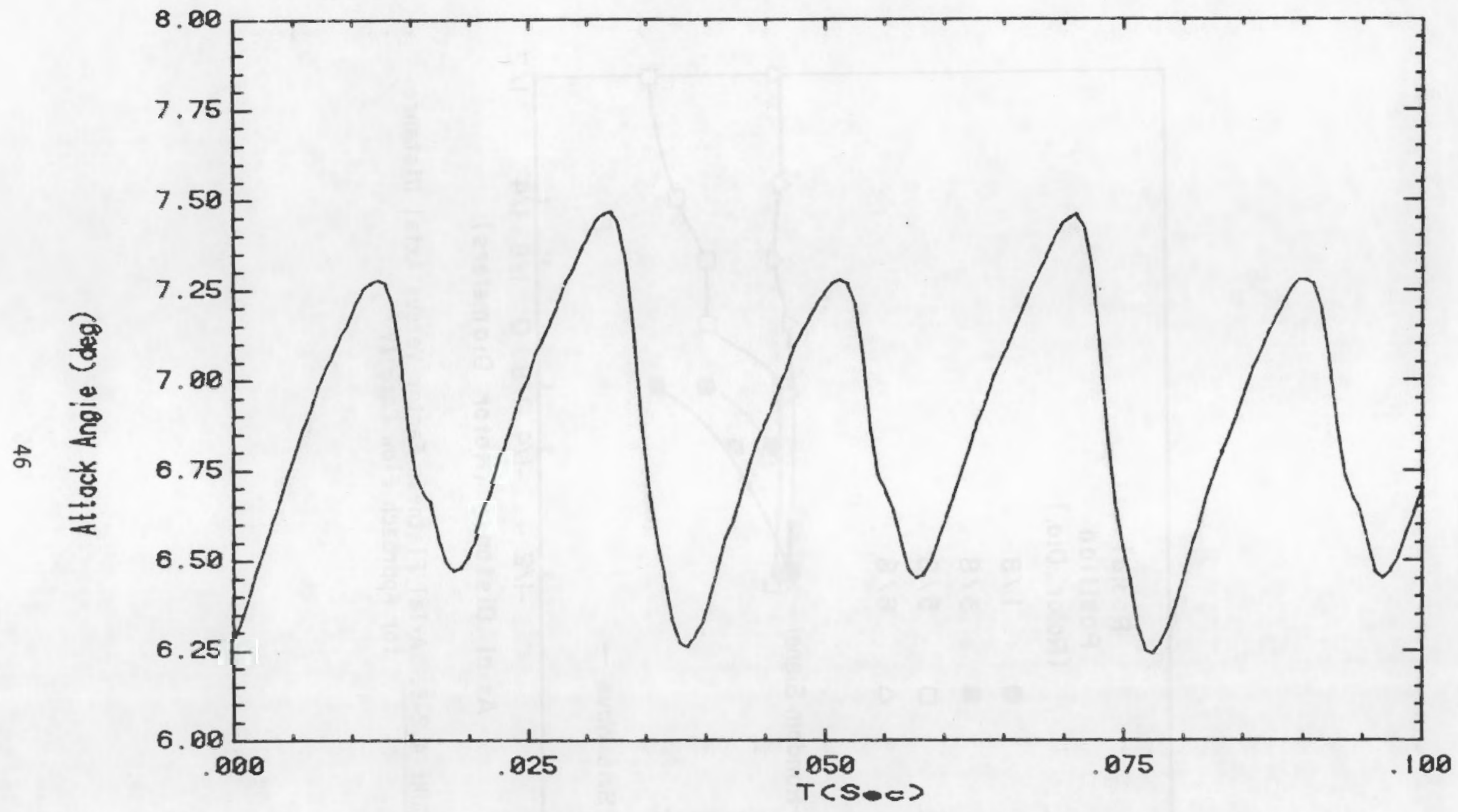

FIGURE 4.2-9. Angle of Attack Time Series for Run No. 1043 
TABLES 
TABLE 2.2-1. Blade Twist Angles Versus Rotor Radius

$\begin{array}{ccc}\begin{array}{c}r \\ (\mathrm{~m})\end{array} & \frac{r / R}{0.021} & \begin{array}{c}\text { Twist Angle } \\ \text { (degree) }\end{array} \\ 0.031 & 0.12 & 37.9 \\ 0.052 & 0.20 & 31.8 \\ 0.062 & 0.24 & 22.5 \\ 0.094 & 0.36 & 19.0 \\ 0.125 & 0.48 & 11.8 \\ 0.156 & 0.60 & 7.5 \\ 0.187 & 0.72 & 4.7 \\ 0.219 & 0.84 & 2.8 \\ 0.250 & 0.96 & 1.4 \\ 0.260 & 1.00 & 0.3\end{array}$

Note: Blade begins at $r=0.016 \mathrm{~m}(r / R=0.061)$ 
TABLE 2.4.4-1. Yaw Angle Calibration Points

\begin{tabular}{|c|c|c|c|c|}
\hline \multirow{2}{*}{$\begin{array}{l}\text { 1st Rotation (a) } \\
\text { About y Axis }\end{array}$} & \multirow{2}{*}{$\begin{array}{l}\text { 2nd Rotation (a) } \\
\text { About x Axis } \\
\end{array}$} & \multicolumn{3}{|c|}{ Yaw Angles (a) } \\
\hline & & $\phi_{1}$ & $\phi_{2}$ & $\phi_{3}$ \\
\hline \multirow[t]{5}{*}{0} & -30 & 17.2 & 17.2 & 65.3 \\
\hline & -15 & 26.9 & 26.9 & 50.3 \\
\hline & 0 & 35.3 & 35.3 & 35.3 \\
\hline & 10 & 39.8 & 39.8 & 25.3 \\
\hline & 20 & 43.0 & 43.0 & 15.3 \\
\hline \multirow[t]{3}{*}{-120} & -30 & 17.2 & 65.3 & 17.2 \\
\hline & -15 & 26.9 & 50.3 & 26.9 \\
\hline & 0 & 35.3 & 35.3 & 35.3 \\
\hline \multirow[t]{3}{*}{120} & -30 & 65.3 & 17.2 & 17.2 \\
\hline & -15 & 50.3 & 26.9 & 26.9 \\
\hline & 0 & 35.3 & 35.3 & 35.3 \\
\hline
\end{tabular}

(a) All angles in degrees, positive rotations about probe coordinate system are clockwise (looking from positive axis to negative axis). 
TABLE 2.4.4-2. Comparison of Actual and Calculated Velocity vectors for 3-D Probe

\begin{tabular}{|c|c|c|c|c|c|c|c|}
\hline \multirow{2}{*}{$\begin{array}{l}\text { Velocity } \\
\mathrm{m} / \mathrm{s}\end{array}$} & \multicolumn{3}{|c|}{$\begin{array}{c}\text { Actual Angle } \\
\text { From Axis (Deg.) }\end{array}$} & \multirow{2}{*}{$\begin{array}{l}\text { Velocity } \\
\mathrm{m} / \mathrm{s}\end{array}$} & \multicolumn{3}{|c|}{$\begin{array}{l}\text { Calculated }(\mathrm{a}) \\
\text { From Axis (Deg.) }\end{array}$} \\
\hline & $\mathrm{X}$ & $Y$ & Z & & $\mathrm{X}$ & $Y$ & Z \\
\hline 4.0 & $\begin{array}{r}40 \\
30 \\
15 \\
0 \\
30 \\
15 \\
15 \\
30 \\
15 \\
30\end{array}$ & $\begin{array}{r}90 \\
90 \\
90 \\
90 \\
120 \\
105 \\
75 \\
60 \\
90 \\
90\end{array}$ & $\begin{array}{r}50 \\
60 \\
75 \\
90 \\
90 \\
90 \\
90 \\
90 \\
105 \\
120\end{array}$ & $\begin{array}{l}4.2 \\
4.1 \\
4.0 \\
4.0 \\
4.1 \\
4.0 \\
4.0 \\
4.1 \\
4.0 \\
4.0\end{array}$ & $\begin{array}{r}41.2 \\
31.9 \\
16.9 \\
0.3 \\
26.4 \\
15.0 \\
15.4 \\
26.2 \\
14.5 \\
22.8\end{array}$ & $\begin{array}{r}88.0 \\
89.1 \\
89.9 \\
90.0 \\
116.3 \\
105.0 \\
74.6 \\
63.9 \\
89.9 \\
89.4\end{array}$ & $\begin{array}{r}48.9 \\
58.2 \\
73.1 \\
89.7 \\
93.1 \\
90.5 \\
90.1 \\
92.5 \\
104.5 \\
112.8\end{array}$ \\
\hline 6.0 & $\begin{array}{r}40 \\
30 \\
15 \\
0 \\
30 \\
15 \\
15 \\
30 \\
15 \\
30\end{array}$ & $\begin{array}{r}90 \\
90 \\
90 \\
90 \\
120 \\
105 \\
75 \\
60 \\
90 \\
90\end{array}$ & $\begin{array}{r}50 \\
60 \\
75 \\
90 \\
90 \\
90 \\
90 \\
90 \\
105 \\
120\end{array}$ & $\begin{array}{l}6.2 \\
6.2 \\
6.1 \\
6.0 \\
6.1 \\
6.0 \\
6.0 \\
6.2 \\
6.0 \\
6.0\end{array}$ & $\begin{array}{r}43.4 \\
32.8 \\
17.1 \\
0.5 \\
27.0 \\
15.4 \\
15.3 \\
26.8 \\
14.6 \\
23.9\end{array}$ & $\begin{array}{r}88.0 \\
89.7 \\
90.1 \\
90.2 \\
116.9 \\
105.4 \\
74.7 \\
63.3 \\
89.7 \\
89.0\end{array}$ & $\begin{array}{r}46.7 \\
57.2 \\
72.5 \\
89.5 \\
92.9 \\
90.4 \\
90.0 \\
92.3 \\
104.6 \\
113.8\end{array}$ \\
\hline 8.0 & $\begin{array}{r}40 \\
30 \\
15 \\
0 \\
30 \\
15 \\
15 \\
30 \\
15 \\
30\end{array}$ & $\begin{array}{r}90 \\
90 \\
90 \\
90 \\
120 \\
105 \\
75 \\
60 \\
90 \\
90\end{array}$ & $\begin{array}{r}50 \\
60 \\
75 \\
90 \\
90 \\
90 \\
90 \\
90 \\
105 \\
120\end{array}$ & $\begin{array}{l}8.2 \\
8.1 \\
8.0 \\
8.0 \\
8.1 \\
8.0 \\
8.1 \\
8.3 \\
8.0 \\
8.1\end{array}$ & $\begin{array}{r}44.8 \\
33.0 \\
16.9 \\
0.4 \\
27.0 \\
15.0 \\
15.2 \\
26.7 \\
14.8 \\
24.3\end{array}$ & $\begin{array}{r}87.3 \\
89.4 \\
90.1 \\
89.7 \\
116.8 \\
105.0 \\
74.8 \\
63.5 \\
89.9 \\
89.4\end{array}$ & $\begin{array}{r}45.4 \\
57.0 \\
73.1 \\
89.7 \\
93.2 \\
90.6 \\
90.1 \\
92.5 \\
104.8 \\
114.3\end{array}$ \\
\hline
\end{tabular}

(a) Velocity calibration on $\theta_{x}=0^{\circ}, \theta_{y}=90^{\circ}, \theta_{z}=0^{\circ}$. Angle calibra-
tion performed at $6.0 \mathrm{~m} / \mathrm{s}$. 
TABLE 2.4.4-3. Comparative Response of Anemometer Probes

\begin{tabular}{|c|c|c|c|c|c|c|c|c|}
\hline \multirow[b]{2}{*}{ Probe } & \multicolumn{4}{|c|}{ Grid Turbulence } & \multicolumn{4}{|c|}{ Cylinder wake Turbulence } \\
\hline & $\mathrm{u}$ & $u^{\prime}$ & $v^{\prime}$ & $w^{\prime}$ & $u$ & $u^{\prime}$ & $v^{\prime}$ & $W^{\prime}$ \\
\hline Single Wire & $5.99 \mathrm{~m} / \mathrm{s}$ & 0.106 & & & 5.7 & 0.407 & & \\
\hline Crosswire & $\begin{array}{l}5.982 \\
5.983\end{array}$ & $\begin{array}{l}0.106 \\
0.109\end{array}$ & 0.0763 & 0.0813 & $\begin{array}{l}5.827 \\
5.776\end{array}$ & $\begin{array}{l}0.374 \\
0.411\end{array}$ & 0.383 & 0.368 \\
\hline $\begin{array}{l}\text { 3-D Probe } \\
(1294-60)\end{array}$ & 5.86 & 0.097 & 0.108 & 0.099 & 5.51 & 0.386 & 0.433 & 0.418 \\
\hline $\begin{array}{l}\text { 3-D Probe } \\
(1294-20)\end{array}$ & 5.90 & 0.096 & 0.100 & 0.096 & & & & \\
\hline
\end{tabular}


TABLE 3.1-1. Approach Flow Characteristics

\begin{tabular}{|c|c|c|c|c|c|c|c|c|c|}
\hline $\begin{array}{l}\text { Approach } \\
\text { Flow No. }\end{array}$ & $\begin{array}{l}\text { Measurement } \\
\text { Probe } \\
\end{array}$ & $\begin{array}{l}\text { Velocity } \\
\text { Component }\end{array}$ & $\begin{array}{c}\text { Minimum } \\
(\mathrm{m} / \mathrm{s})\end{array}$ & $\begin{array}{r}\text { Mean } \\
(\mathrm{m} / \mathrm{s}) \\
\end{array}$ & $\begin{array}{c}\text { Maximum } \\
(\mathrm{m} / \mathrm{s}) \\
\end{array}$ & $\begin{array}{c}\text { RMS } \\
(\mathrm{m} / \mathrm{s}) \\
\end{array}$ & Skewness & Flatness & $\begin{array}{l}\text { Integral } \\
\text { Scale (m) }\end{array}$ \\
\hline 1 & single film & u & 5.878 & 5.900 & 5.924 & 0.007 & 0.162 & 2.934 & \\
\hline 2 & single film & u & 7.500 & 7.538 & 7.588 & 0.009 & 0.188 & 3.106 & \\
\hline 3 & single film & u & 5.491 & 5.928 & 6.330 & 0.107 & -0.045 & 2.952 & 0.0463 \\
\hline 4 & single film & u & 6.980 & 7.516 & 8.033 & 0.131 & 0.0414 & 2.900 & 0.0425 \\
\hline 1 & 3-D Probe & u & 5.877 & 5.90 & 5.918 & 0.007 & -0.0346 & 2.441 & \\
\hline 2 & 3-D Probe & u & 7.581 & 7.60 & 7.622 & 0.007 & 1.092 & 2.858 & \\
\hline 3 & 3-D Probe & $\mathrm{u}$ & 5.580 & 5.96 & 6.325 & 0.100 & -0.120 & 2.963 & 0.0517 \\
\hline 4 & 3-D Probe & $u$ & 7.060 & 7.59 & 8.057 & 0.120 & -0.039 & 2.912 & 0.0504 \\
\hline 1 & 3-D Probe & $v$ & -0.014 & 0.01 & 0.045 & 0.008 & 0.072 & 3.167 & \\
\hline 2 & 3-D Probe & $v$ & -0.142 & -0.08 & -0.028 & 0.016 & 0.086 & 2.671 & \\
\hline 3 & 3-D Probe & $v$ & -0.581 & -0.08 & 0.392 & 0.106 & -0.003 & 3.006 & 0.0147 \\
\hline 4 & 3-D Probe & $v$ & -0.758 & -0.11 & 0.478 & 0.139 & -0.039 & 3.177 & 0.0152 \\
\hline 1 & 3-D Probe & $w$ & -0.004 & 0.02 & 0.052 & 0.008 & -0.018 & 2.966 & \\
\hline 2 & 3-0 Probe & $w$ & 0.036 & 0.08 & 0.116 & 0.011 & -0.116 & 2.744 & \\
\hline 3 & 3-D Probe & $w$. & -0.429 & 0.07 & 0.482 & 0.101 & -0.090 & 3.104 & 0.0171 \\
\hline 4 & 3-D Probe & $w$ & -0.618 & 0.12 & 0.622 & 0.128 & -0.040 & 3.156 & 0.0164 \\
\hline
\end{tabular}


TABLE 3.2-1. Power Measurement Test for $\bar{U}=6.0 \mathrm{~m} / \mathrm{s}, T_{0} I .=0.1 \%$

\begin{tabular}{|c|c|c|c|c|c|}
\hline $\begin{array}{l}\text { Mass } \\
(\mathrm{kg})\end{array}$ & 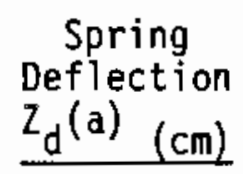 & $\begin{array}{c}0 \\
\text { (rpm) }\end{array}$ & $\begin{array}{c}\text { Tip Speed } \\
\text { Ratio } \\
\end{array}$ & $\begin{array}{c}\text { Power } \\
\text { (watts) }\end{array}$ & $\begin{array}{c}\text { Power } \\
\text { Coefficient }\end{array}$ \\
\hline 0.091 & 8.5 & 1640 & 7.4 & 1.13 & 0.050 \\
\hline 0.227 & 10.0 & 1545 & 7.01 & 2.79 & 0.124 \\
\hline 0.318 & 11.1 & 1460 & 6.62 & 3.57 & 0.158 \\
\hline 0.408 & 12.3 & 1370 & 6.22 & 4.19 & 0.186 \\
\hline 0.454 & 12.7 & 1330 & 6.03 & 4.58 & 0.203 \\
\hline 0.499 & 13.2 & 1300 & 5.90 & 4.95 & 0.219 \\
\hline 0.545 & 13.8 & 1230 & 5.58 & 5.01 & 0.222 \\
\hline 0.635 & 14.7 & 1180 & 5.35 & 5.8 & 0.757 \\
\hline 0.681 & 15.1 & 1135 & 5.15 & 6.16 & 0.273 \\
\hline 0.726 & 15.7 & 1080 & 4.9 & 6.13 & 0.272 \\
\hline 0.771 & 16.3 & 980 & 4.45 & 5.8 & 0.257 \\
\hline
\end{tabular}

(a) $\mathrm{Z}_{\mathrm{d}}=7.45 \mathrm{~cm}$. 
TABLE $3.2-2$. Power Measurement Test for $\bar{U}=7.6 \mathrm{~m} / \mathrm{s}$, T.I. $=0.1 \%$

\begin{tabular}{|c|c|c|c|c|c|}
\hline $\begin{array}{l}\text { Mass } \\
(\mathrm{kg})\end{array}$ & $\begin{array}{c}\text { Spring } \\
\text { Deflection } \\
Z_{d}(a) \text { (cm) }\end{array}$ & $\begin{array}{c}n \\
(\mathrm{rpm})\end{array}$ & $\begin{array}{c}\text { Tip Speed } \\
\text { Ratio } \\
\end{array}$ & $\begin{array}{l}\text { Power } \\
\text { (watts) }\end{array}$ & $\begin{array}{c}\text { Power } \\
\text { Coefficient }\end{array}$ \\
\hline 0.453 & 12.6 & 1925 & 6.89 & 6.81 & 0.148 \\
\hline 0.544 & 13.6 & 1900 & 6.80 & 8.15 & 0.178 \\
\hline 0.680 & 15.0 & 1805 & 6.46 & 9.97 & 0.217 \\
\hline 0.770 & 16.1 & 1760 & 6.30 & 10.80 & 0.235 \\
\hline 0.906 & 17.6 & 1645 & 5.89 & 11.93 & 0.260 \\
\hline 0.997 & 18.7 & 1575 & 5.64 & 12.40 & 0.271 \\
\hline 1.088 & 19.2 & 1460 & 5.23 & 13.46 & 0.293 \\
\hline
\end{tabular}

(a) $Z_{d}=7.45 \mathrm{~cm}$. 
TABLE 3.2-3. Power Measurement Test for $\bar{U}=7.6 \mathrm{~m} / \mathrm{s}$, T. I. $=1.5 \%$

\begin{tabular}{|c|c|c|c|c|c|}
\hline $\begin{array}{l}\text { Mass } \\
(\mathrm{kg})\end{array}$ & $\begin{array}{c}\text { Spring } \\
\text { Deflection } \\
Z_{d}(a)(\mathrm{cm}) \\
\end{array}$ & $\begin{array}{c}n \\
(r p m)\end{array}$ & $\begin{array}{l}\text { Tip Speed } \\
\text { Ratio } \\
\end{array}$ & $\begin{array}{c}\text { Power } \\
\text { (watts) }\end{array}$ & $\begin{array}{c}\text { Power } \\
\text { Coefficient }\end{array}$ \\
\hline 0.453 & 13.0 & 2080 & 7.45 & 6.39 & 0.139 \\
\hline 0.544 & 13.8 & 1980 & 7.09 & 8.03 & 0.175 \\
\hline 0.680 & 15.2 & 1860 & 6.66 & 9.83 & 0.214 \\
\hline 0.771 & 16.2 & 1840 & 6.59 & 11.11 & 0.242 \\
\hline 0.861 & 17.1 & 1770 & 6.34 & 12.19 & 0.266 \\
\hline 0.906 & 17.4 & 1700 & 6.09 & 12.72 & 0.277 \\
\hline 0.996 & 18.1 & 1640 & 5.87 & 14.00 & 0.306 \\
\hline 1.087 & 18.6 & 1510 & 5.41 & 14.90 & 0.326 \\
\hline 1.132 & 18.7 & 1380 & 4.94 & 14.70 & 0.322 \\
\hline 1.222 & 18.6 & 1240 & 4.44 & 15.80 & 0.344 \\
\hline 1.313 & 18.7 & 1080 & 3.87 & 15.68 & 0.342 \\
\hline
\end{tabular}

(a) $Z_{d}=7.45 \mathrm{~cm}$. 
TABLE 3.3-1. Measurement Locations

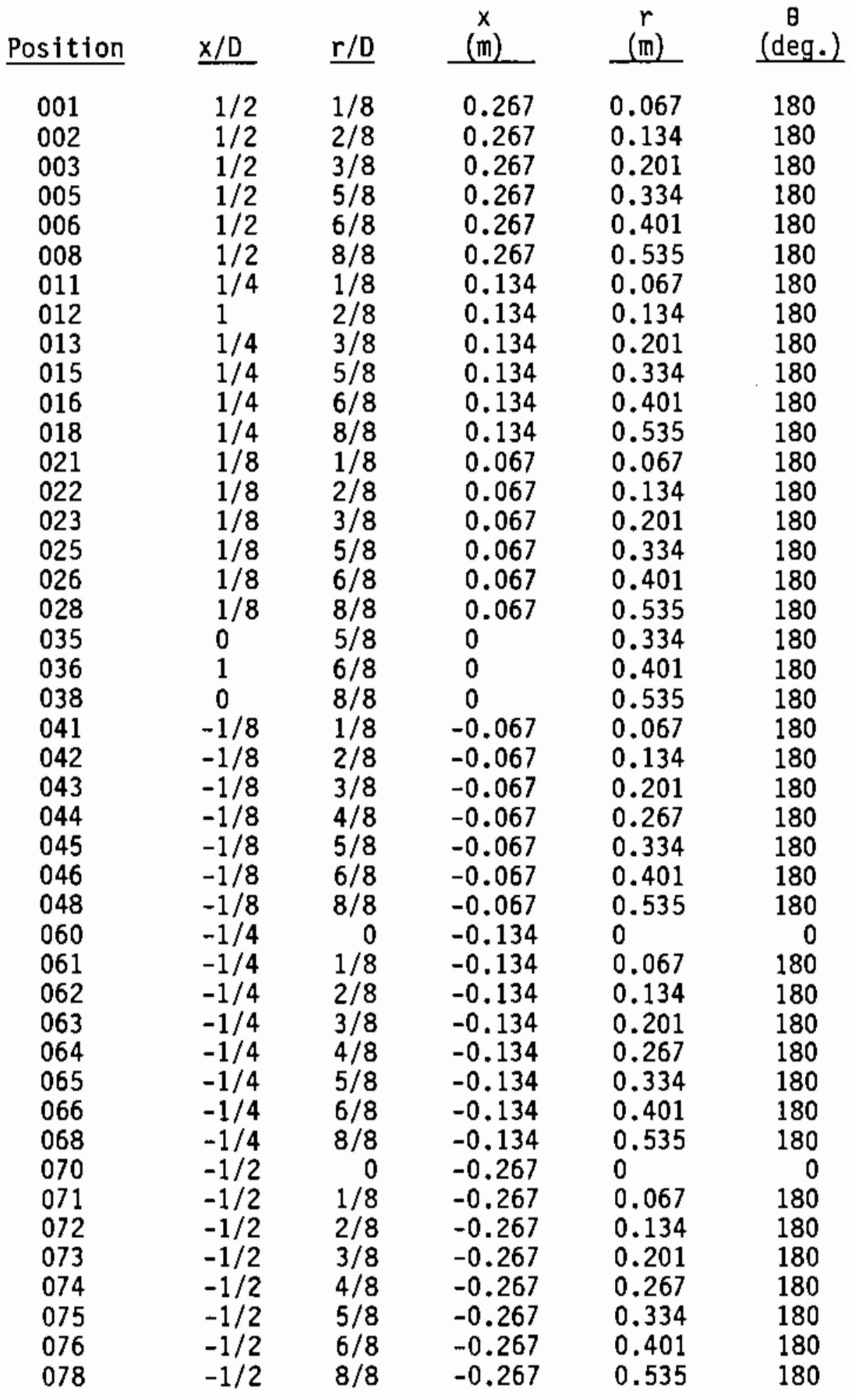


TABLE 3.3-1. (contd)

\begin{tabular}{|c|c|c|c|c|c|}
\hline Position & $x / D$ & $r / D$ & $\begin{array}{c}x \\
(\mathrm{~m}) \\
\end{array}$ & $\begin{array}{c}r \\
(m)\end{array}$ & $\begin{array}{c}\theta \\
(\operatorname{deg} .)\end{array}$ \\
\hline 080 & 1 & 0 & -0.535 & 0 & 0 \\
\hline 082 & 1 & $1 / 4$ & -0.535 & 0.134 & 180 \\
\hline OB4 & 1 & $2 / 4$ & -0.535 & 0.267 & 180 \\
\hline 086 & 1 & $3 / 4$ & -0.535 & 0.401 & 180 \\
\hline 088 & 1 & $4 / 4$ & -0.535 & 0.535 & 180 \\
\hline 090 & $3 / 2$ & 0 & -0.802 & 0 & 0 \\
\hline 094 & $3 / 2$ & $1 / 2$ & -0.802 & 0.267 & 180 \\
\hline 098 & $3 / 2$ & $2 / 2$ & -0.802 & 0.535 & 180 \\
\hline 100 & 2 & 0 & -1.070 & 0 & 0 \\
\hline 104 & 2 & $1 / 2$ & -1.070 & 0.267 & 180 \\
\hline 108 & 2 & $2 / 2$ & -1.070 & 0.535 & 180 \\
\hline 110 & 3 & 0 & -1.605 & & 0 \\
\hline 114 & 3 & $1 / 2$ & -1.605 & 0.267 & 180 \\
\hline 118 & 3 & $2 / 2$ & -1.605 & 0.535 & 180 \\
\hline
\end{tabular}


TABLE 3.3-2. Rotor Speed During Data Acquisition

Position No. Case No.

$\begin{array}{lcccc} & \text { (Data } & \text { Obtained with TSI } & \text { 1294-20 Probe) } & \\ 001 & 1340 & 1600 & 1470 & 1360 \\ 002 & 1340 & 1600 & 1470 & 1370 \\ 003 & 1340 & 1580 & 1440 & 1350 \\ 005 & 1340 & 1560 & 1440 & 1340 \\ 006 & 1300 & 1525 & 1440 & 1330 \\ 008 & 1340 & 1525 & 1440 & 1320 \\ 011 & 1360 & 1500 & 1420 & 1320 \\ 012 & 1360 & 1500 & 1420 & 1350 \\ 013 & 1360 & 1500 & 1420 & 1350 \\ 015 & 1360 & 1500 & 1420 & 1370 \\ 016 & 1360 & 1510 & 1440 & 1360 \\ 018 & 1340 & 1510 & 1440 & 1350 \\ 021 & 1380 & 1500 & 1400 & 1350 \\ 022 & 1380 & 1450 & 1420 & 1370 \\ 023 & 1380 & 1450 & 1420 & 1370 \\ 025 & 1380 & 1450 & 1420 & 1370 \\ 026 & 1430 & 1465 & 1420 & 1500 \\ 028 & 1430 & 1465 & 1420 & 1560 \\ 035 & 1430 & 1390 & 1380 & 1550 \\ 036 & 1430 & 1390 & 1400 & 1520 \\ 038 & 1430 & 1390 & 1400 & 1520 \\ 045 & 1420 & 1400 & 1400 & 1580 \\ 046 & 1406 & 1400 & 1400 & 1580 \\ 048 & 1490 & 1420 & 1400 & 1600\end{array}$

(Data Obtained with Modified TSI $1294-20$ Probe, $90^{\circ}$ Bend)

$\begin{array}{lllll}041 & 1550 & 1540 & 1354 & 1360 \\ 042 & 1550 & 1540 & 1354 & 1360 \\ 043 & 1550 & 1530 & 1354 & 1360 \\ 044 & 1550 & 1420 & 1354 & 1360 \\ 045 & 1550 & 1380 & 1354 & 1360 \\ 046 & 1550 & 1420 & 1354 & 1320 \\ 048 & 1540 & 1380 & 1354 & 1320 \\ 060 & 1500 & 1380 & 1300 & 1370 \\ 061 & 1500 & 1400 & 1320 & 1370 \\ 062 & 1520 & 1430 & 1320 & 1370 \\ 063 & 1530 & 1400 & 1320 & 1430 \\ 064 & 1530 & 1340 & 1320 & 1430 \\ 065 & 1530 & 1340 & 1320 & 1430 \\ 066 & 1530 & 1460 & 1320 & 1350 \\ 068 & 1540 & 1460 & 1320 & 1350\end{array}$


TABLE 3.3-2. (contd)

\begin{tabular}{|c|c|c|c|c|}
\hline \multirow{2}{*}{$\begin{array}{l}\text { Position } \\
\quad \text { No. } \\
\end{array}$} & \multicolumn{4}{|c|}{ Case No. } \\
\hline & 1 & 2 & 3 & 4 \\
\hline (Data & tained & TSI 1 & Probe & \\
\hline 070 & 1490 & 1450 & 1310 & 1430 \\
\hline 071 & 1465 & 1410 & 1310 & 1430 \\
\hline 072 & 1465 & 1420 & 1310 & 1430 \\
\hline 073 & 1465 & 1460 & 1330 & 1430 \\
\hline 074 & 1465 & 1340 & 1330 & 1430 \\
\hline 075 & 1465 & 1370 & 1330 & 1430 \\
\hline 076 & 1465 & 1370 & 1330 & 1390 \\
\hline 078 & 1440 & 1430 & 1330 & 1310 \\
\hline 080 & 1320 & 1413 & 1330 & 1310 \\
\hline 082 & 1320 & 1450 & 1330 & 1310 \\
\hline 084 & 1320 & 1465 & 1330 & 1310 \\
\hline 086 & 1320 & 1413 & 1330 & 1310 \\
\hline 088 & 1300 & 1450 & 1330 & 1310 \\
\hline 090 & 1350 & 1460 & 1350 & 1310 \\
\hline 094 & 1350 & 1420 & 1350 & 1310 \\
\hline 098 & 1350 & 1420 & 1350 & 1310 \\
\hline 100 & 1420 & 1550 & 1400 & 1310 \\
\hline 104 & 1400 & 1465 & 1400 & 1310 \\
\hline 108 & 1400 & 1525 & 1400 & 1310 \\
\hline 110 & 1500 & 1600 & 1465 & 1310 \\
\hline 114 & 1500 & 1600 & 1443 & 1310 \\
\hline 11 & 1465 & 1600 & 1400 & 1310 \\
\hline
\end{tabular}




\section{TABLE 3.3-3. Near-Field Velocity Information}

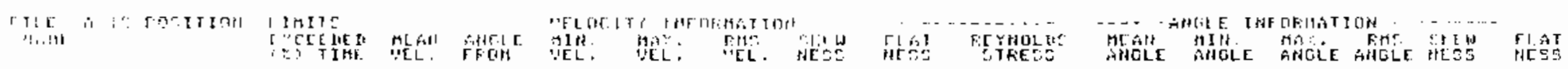

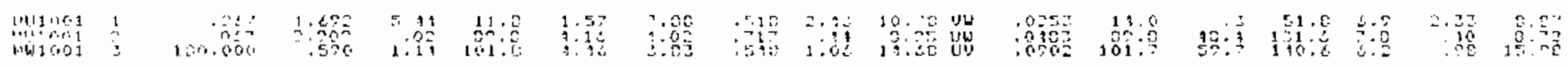

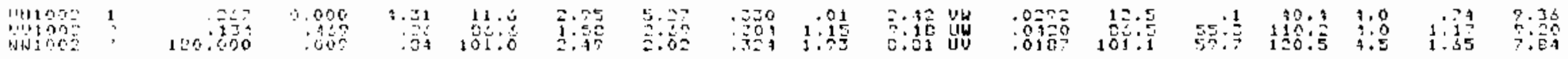

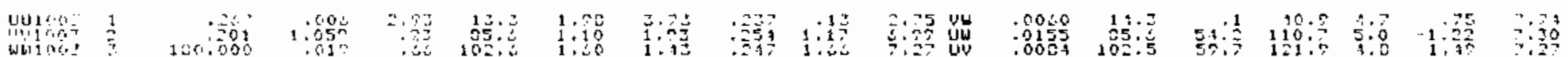

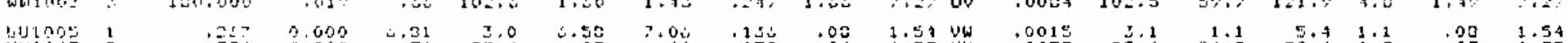

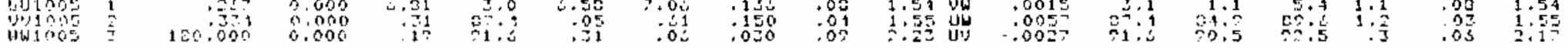

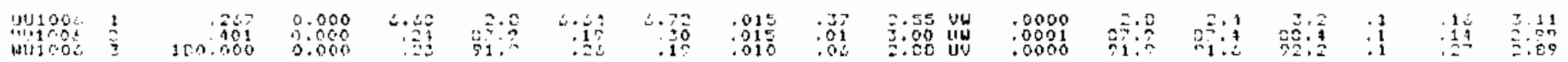

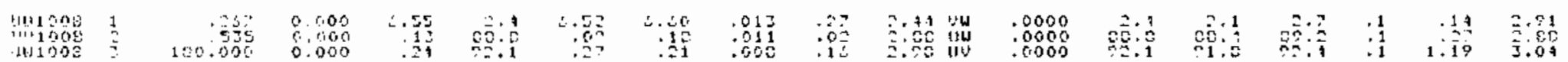

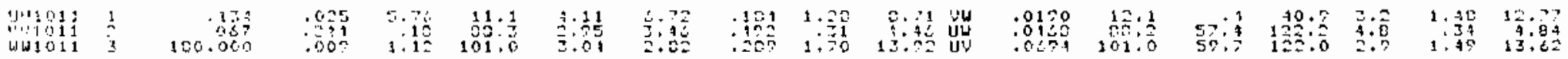

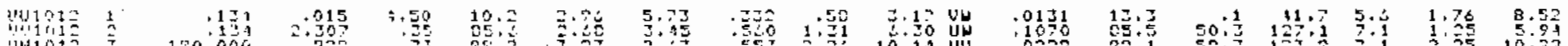

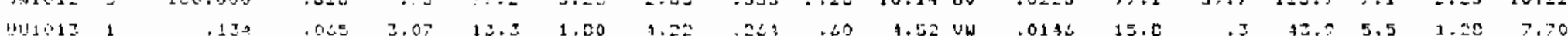

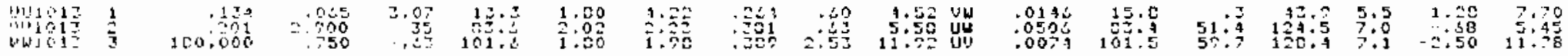

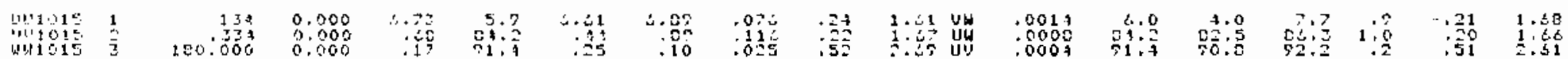

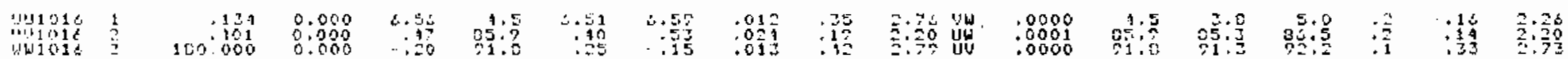

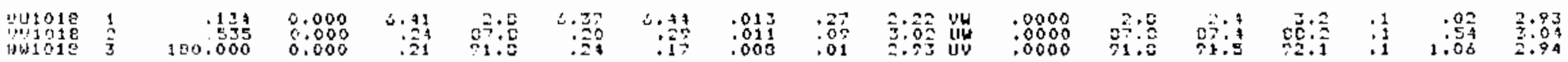

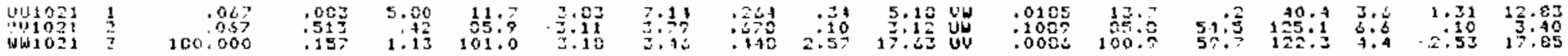

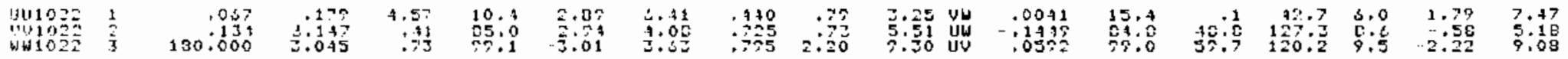

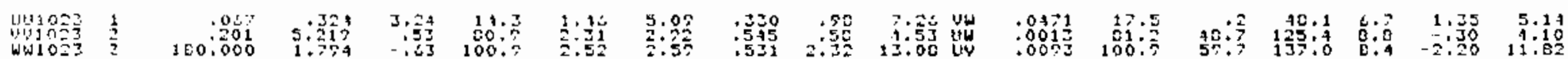




\section{TABLE 3.3-3. (contd)}

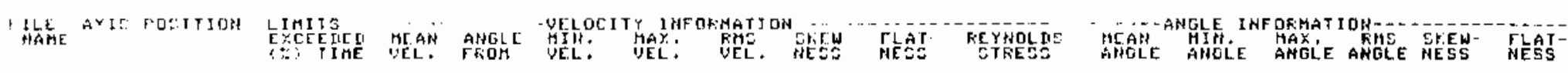

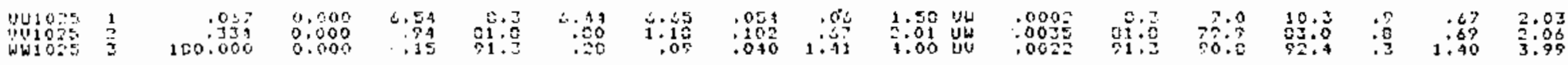

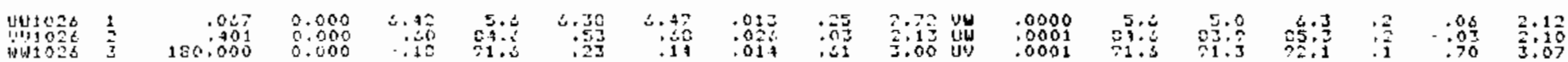

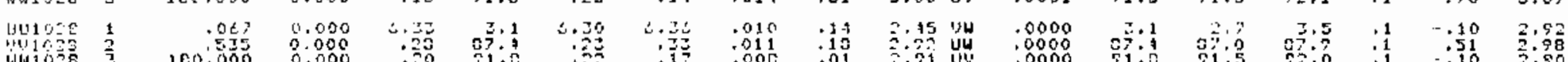

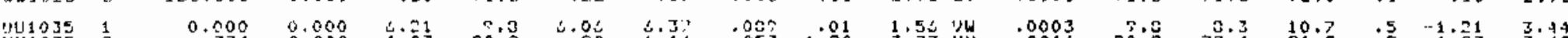

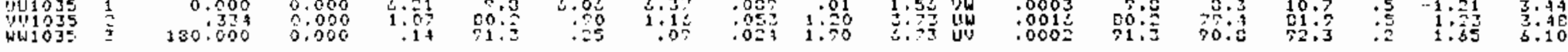

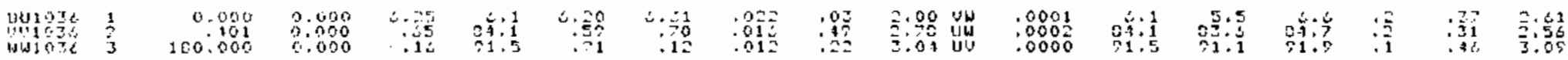

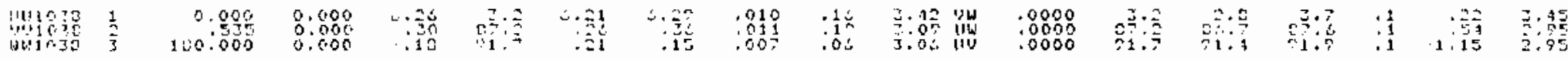

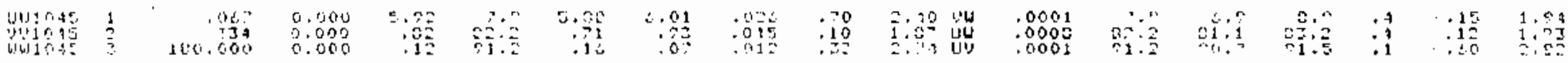

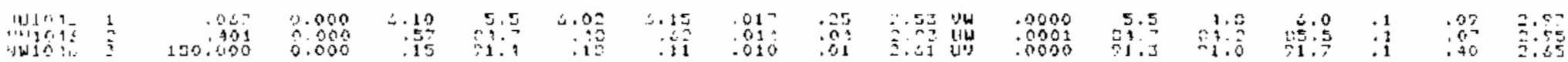

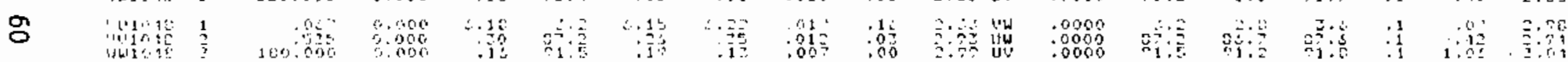


TABLE 3.3-3. (contd)

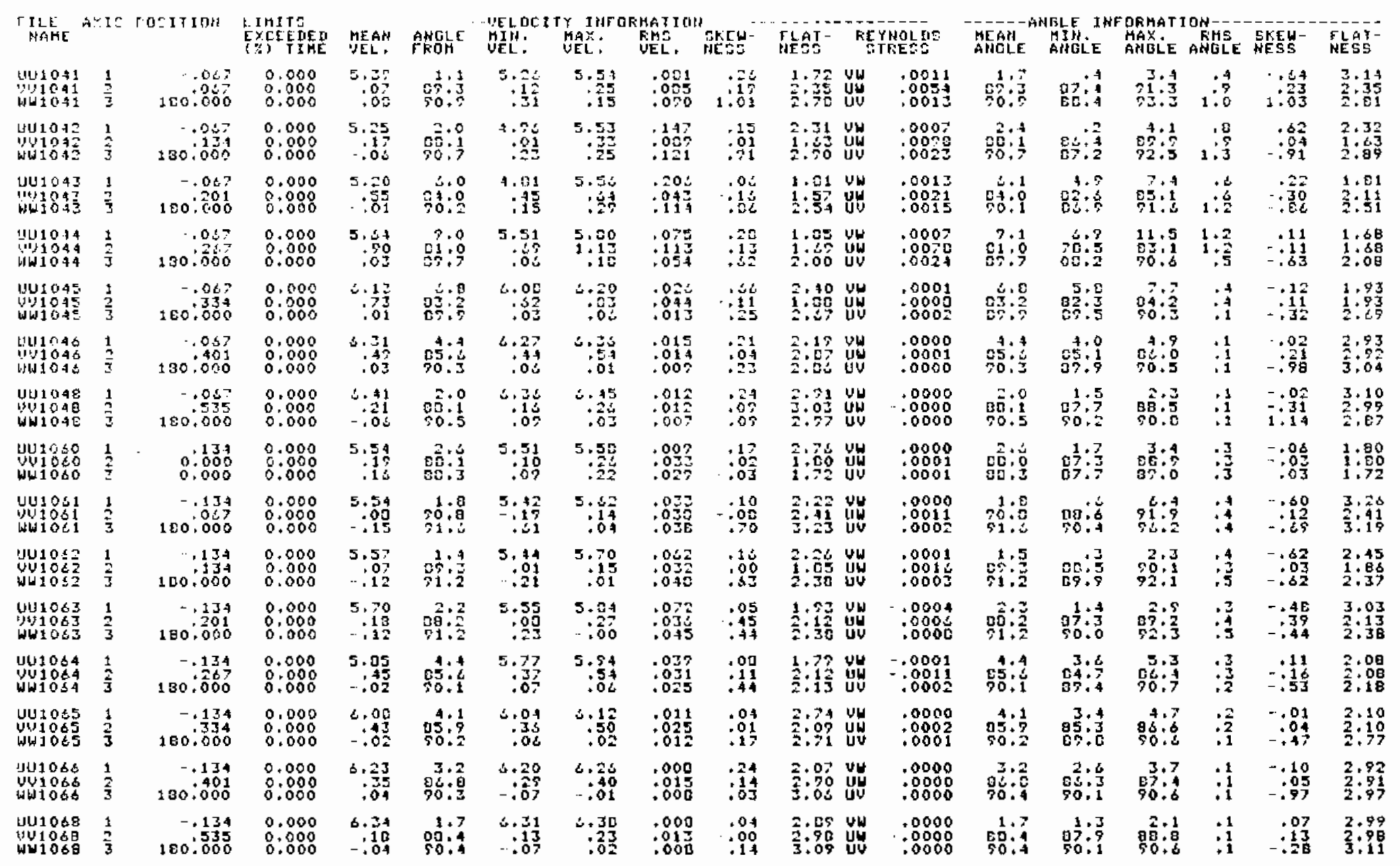


IABLE 3.3-3. (contd)

FILE AXIS POSITIOH LIMITS -

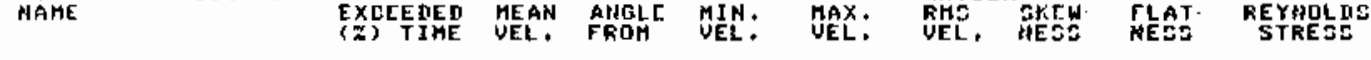

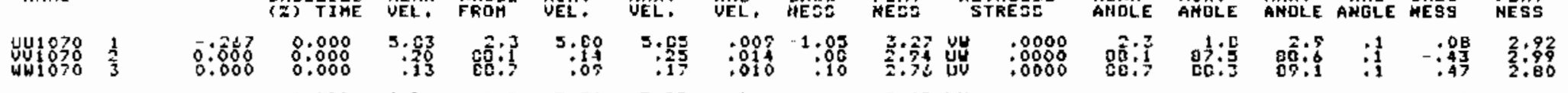

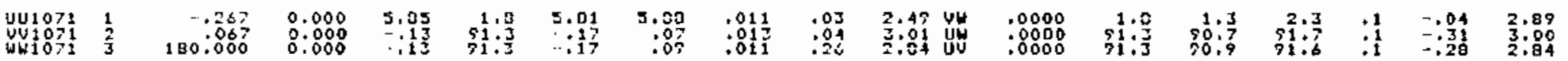

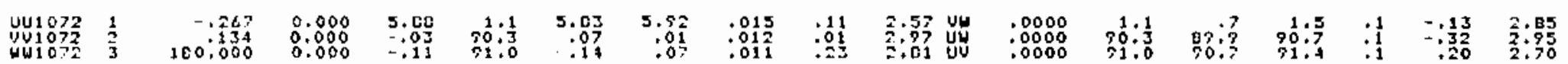

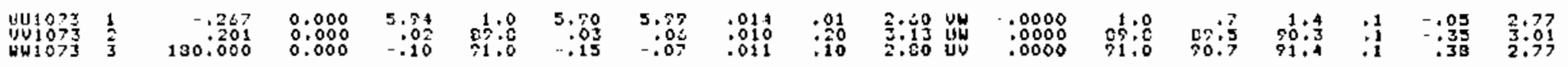

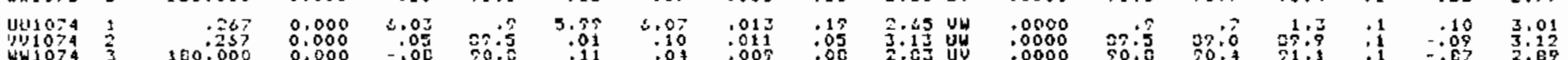

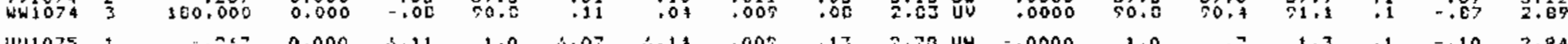

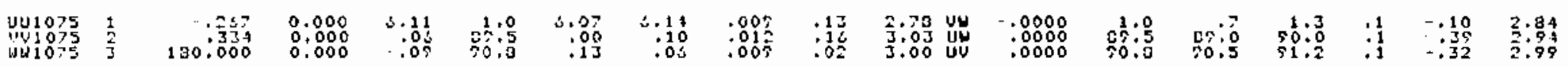

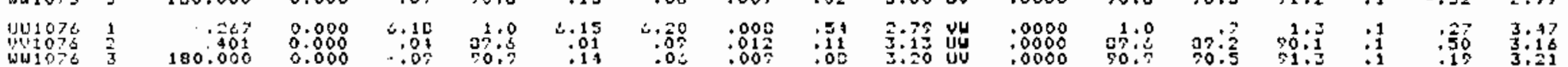

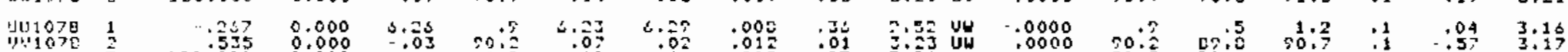

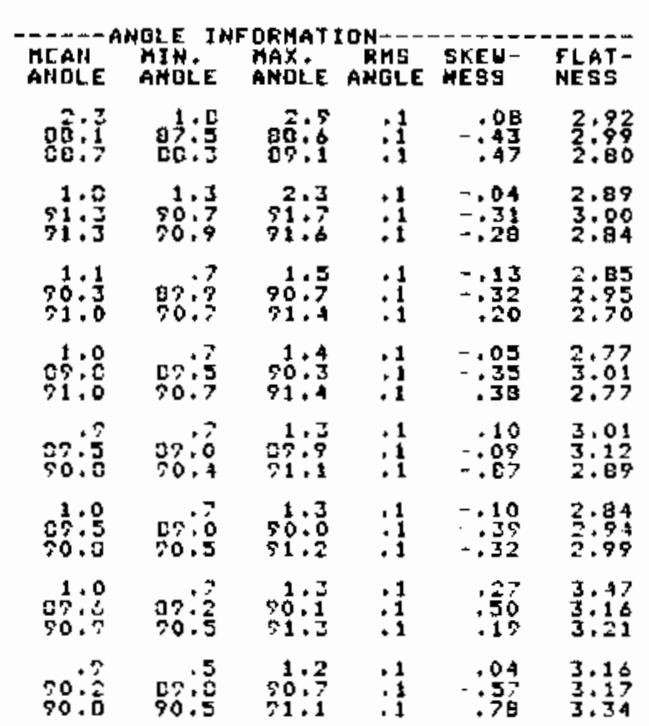




\section{TABLE 3.3-3. (contd)}

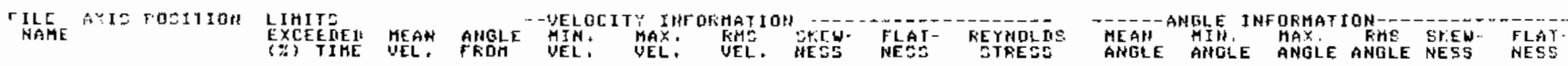

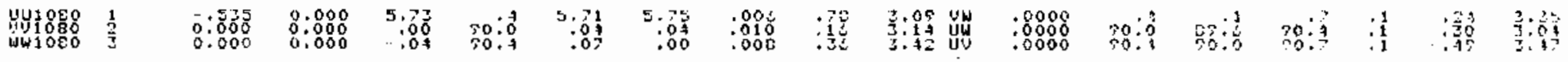

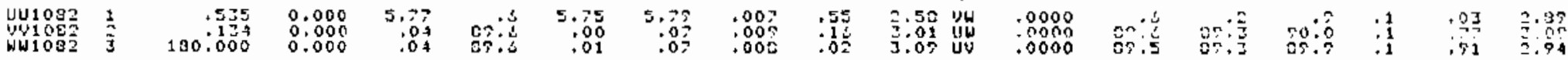

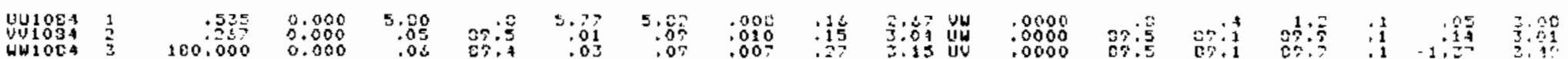

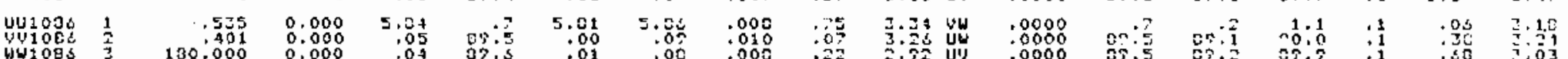

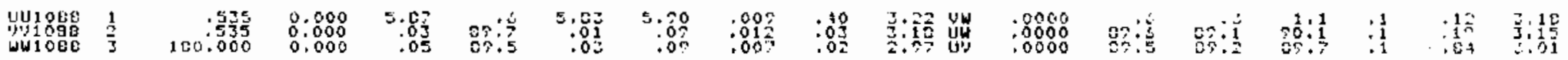

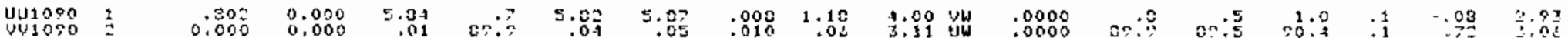

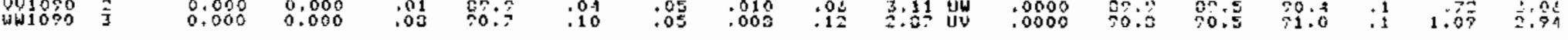

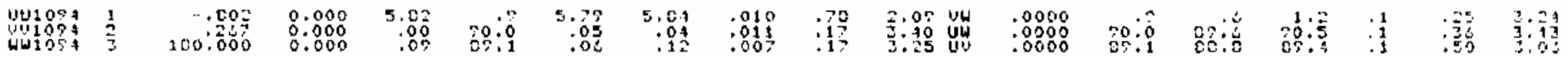

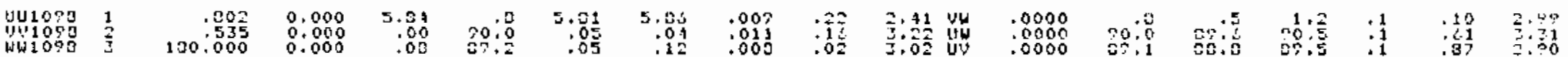

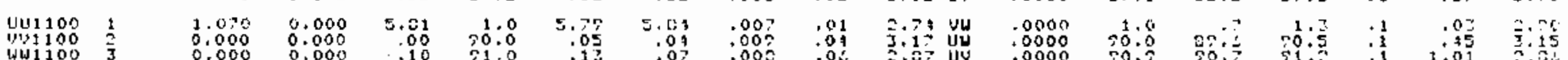

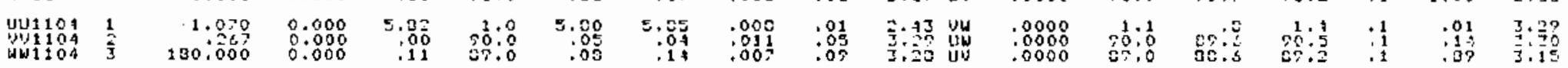

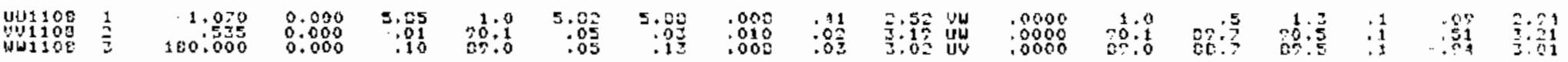

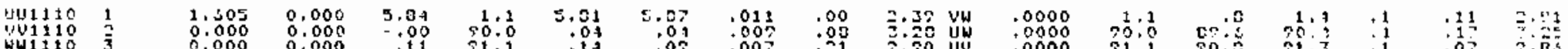

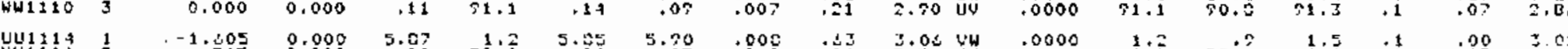

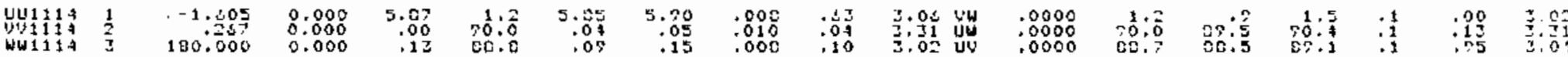

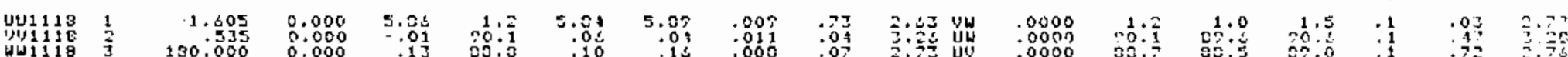

Note: $\overline{\mathbf{u}}$ values are $2.5 \%$ low. 
TABLE 3.3-3. (contd)

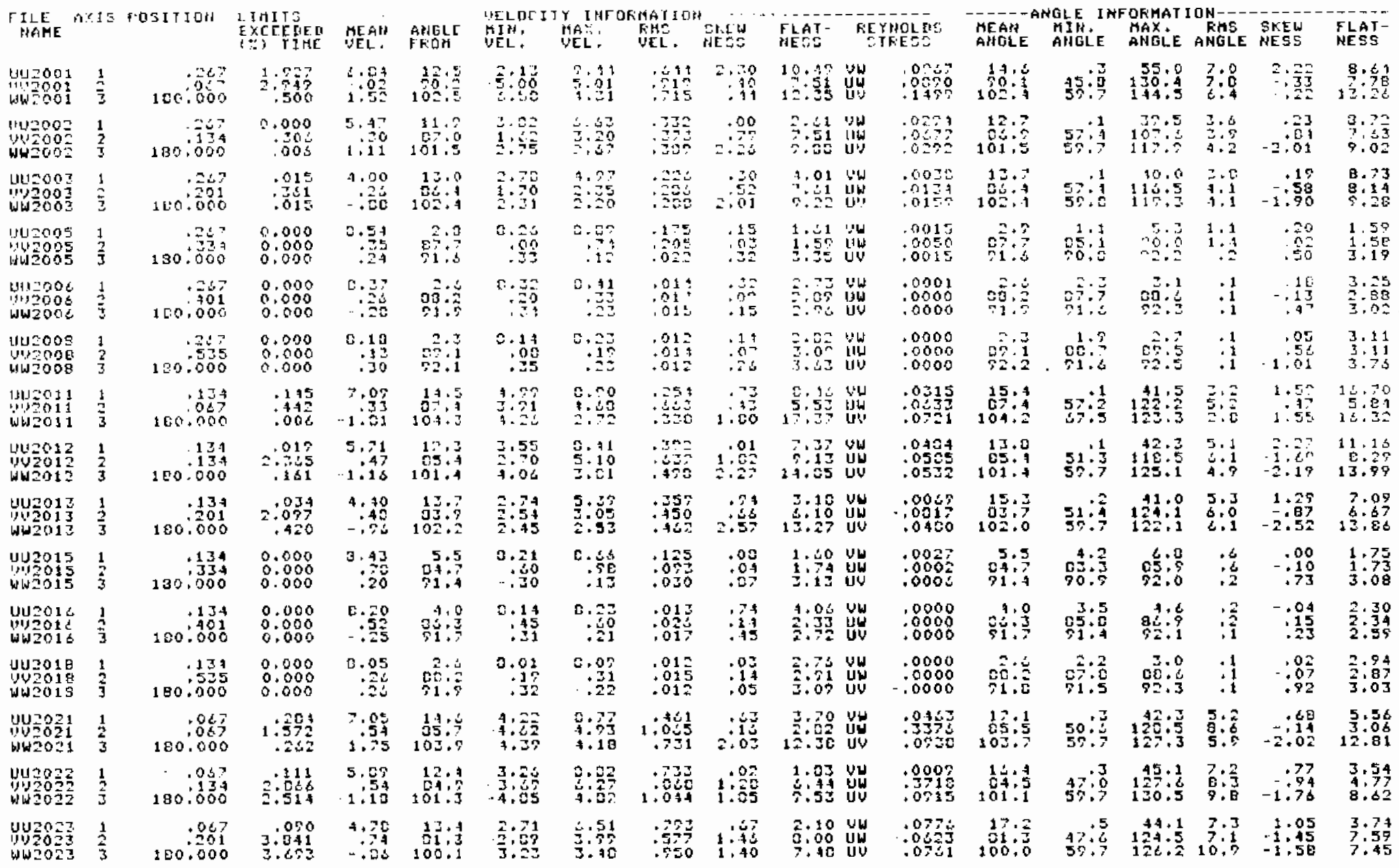




\section{TABLE 3.3-3. (contd)}

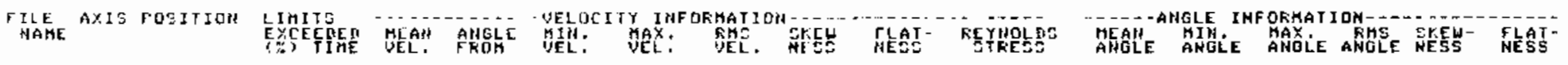

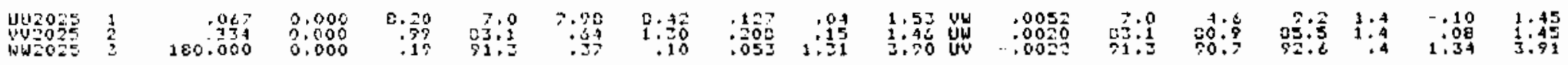

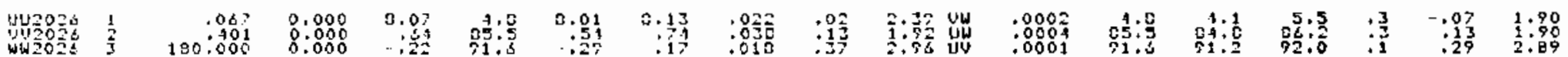

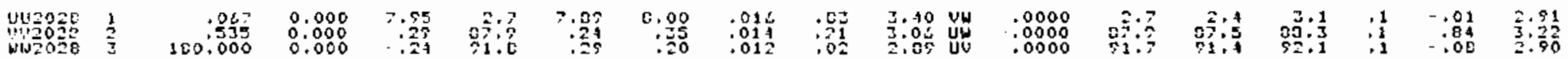

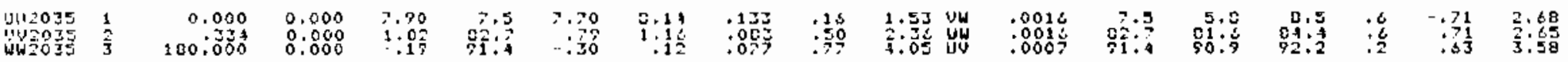

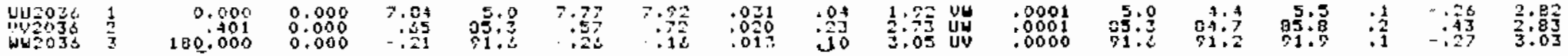

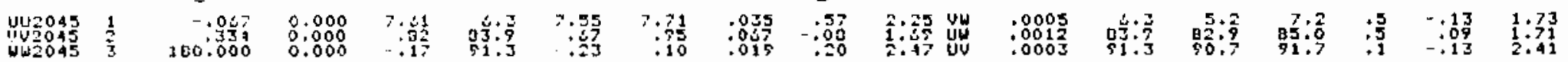

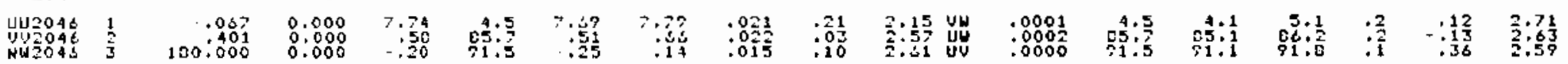


TABLE 3.3-3. (contd)

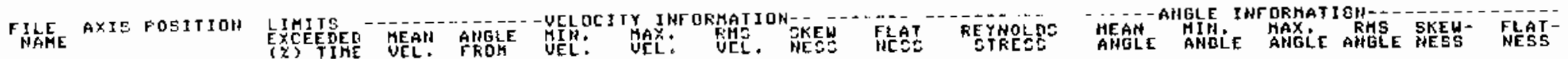

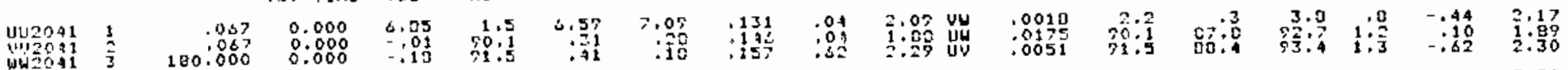

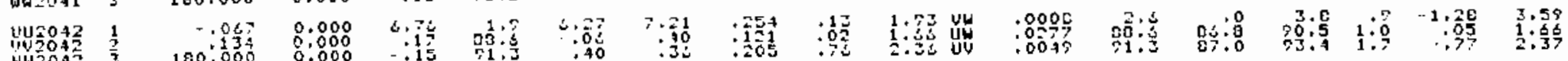

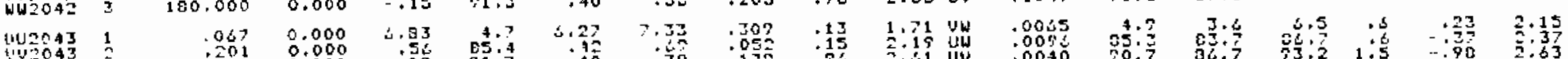

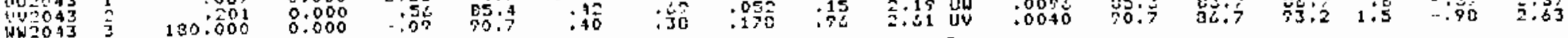

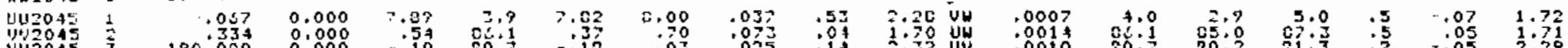

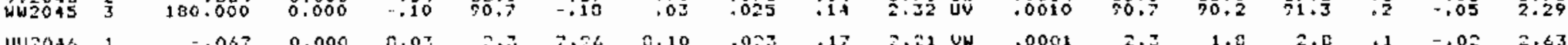

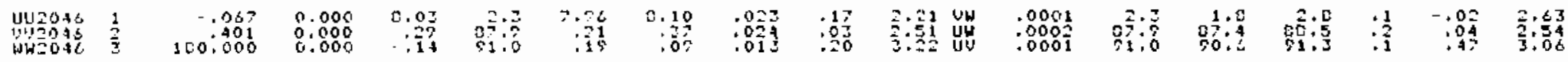

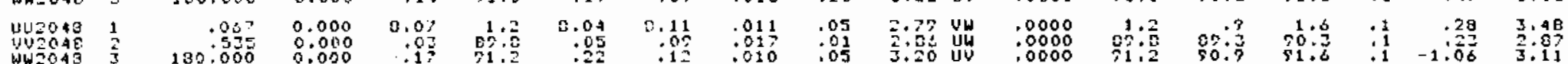

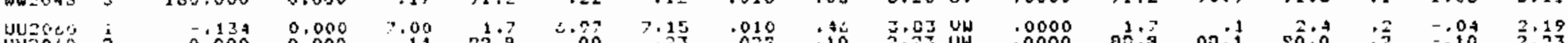

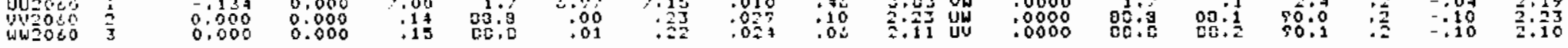

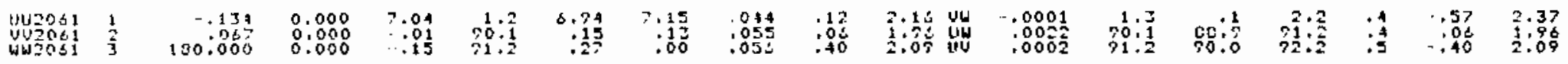

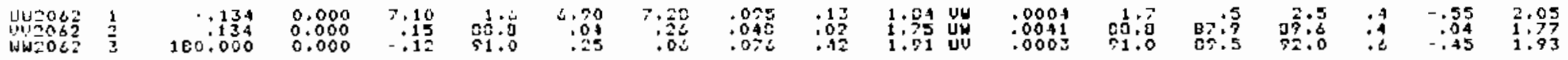

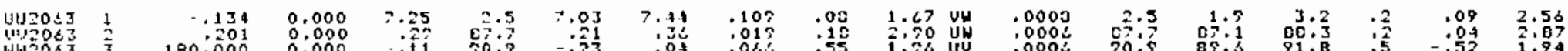

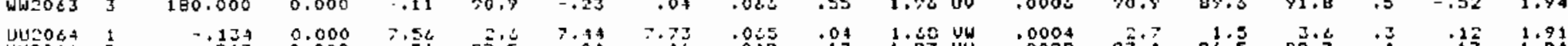

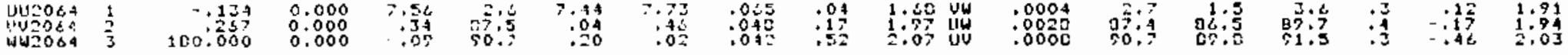

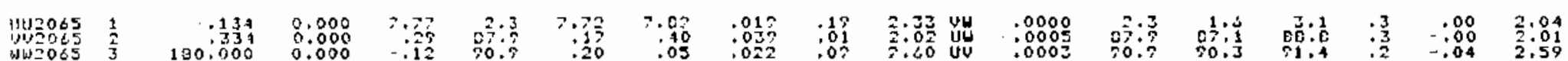

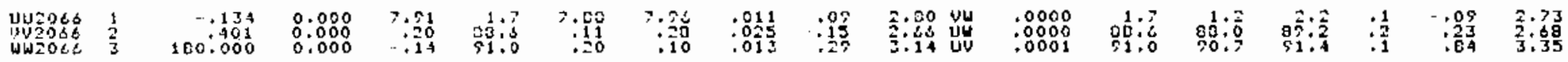

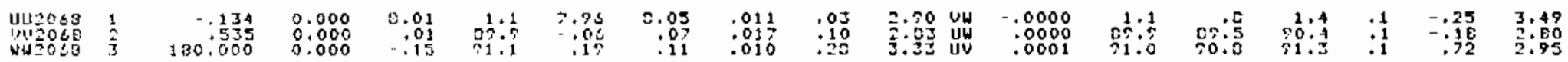




\section{TABLE 3.3-3. (contd)}

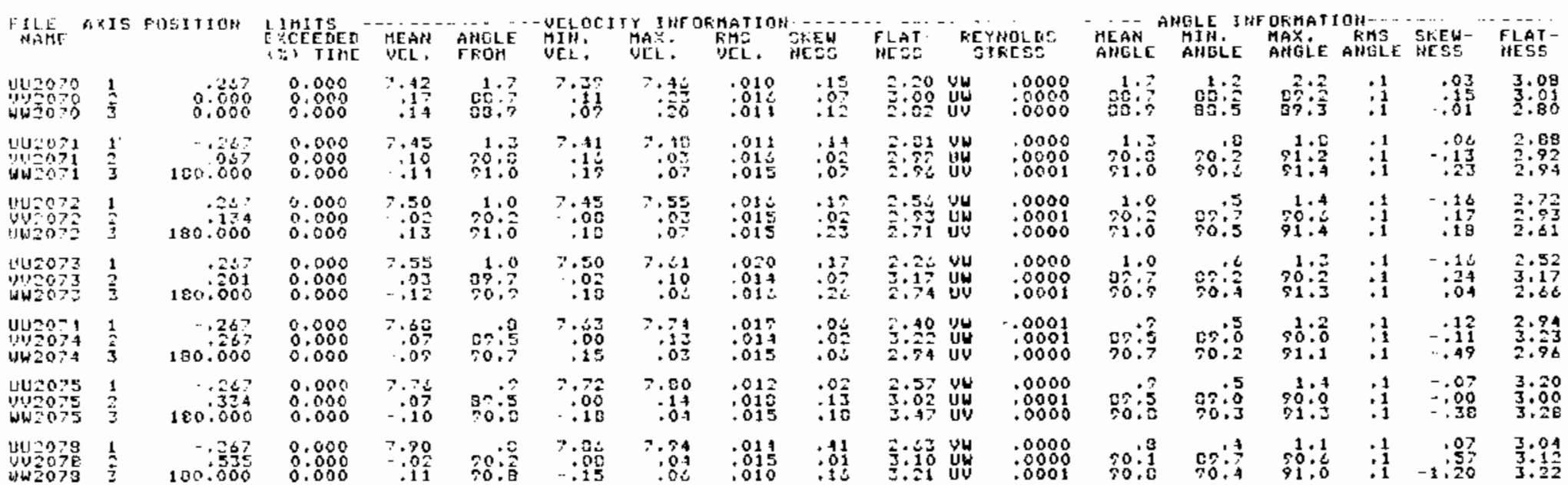


TABLE 3.3-3. (contd)

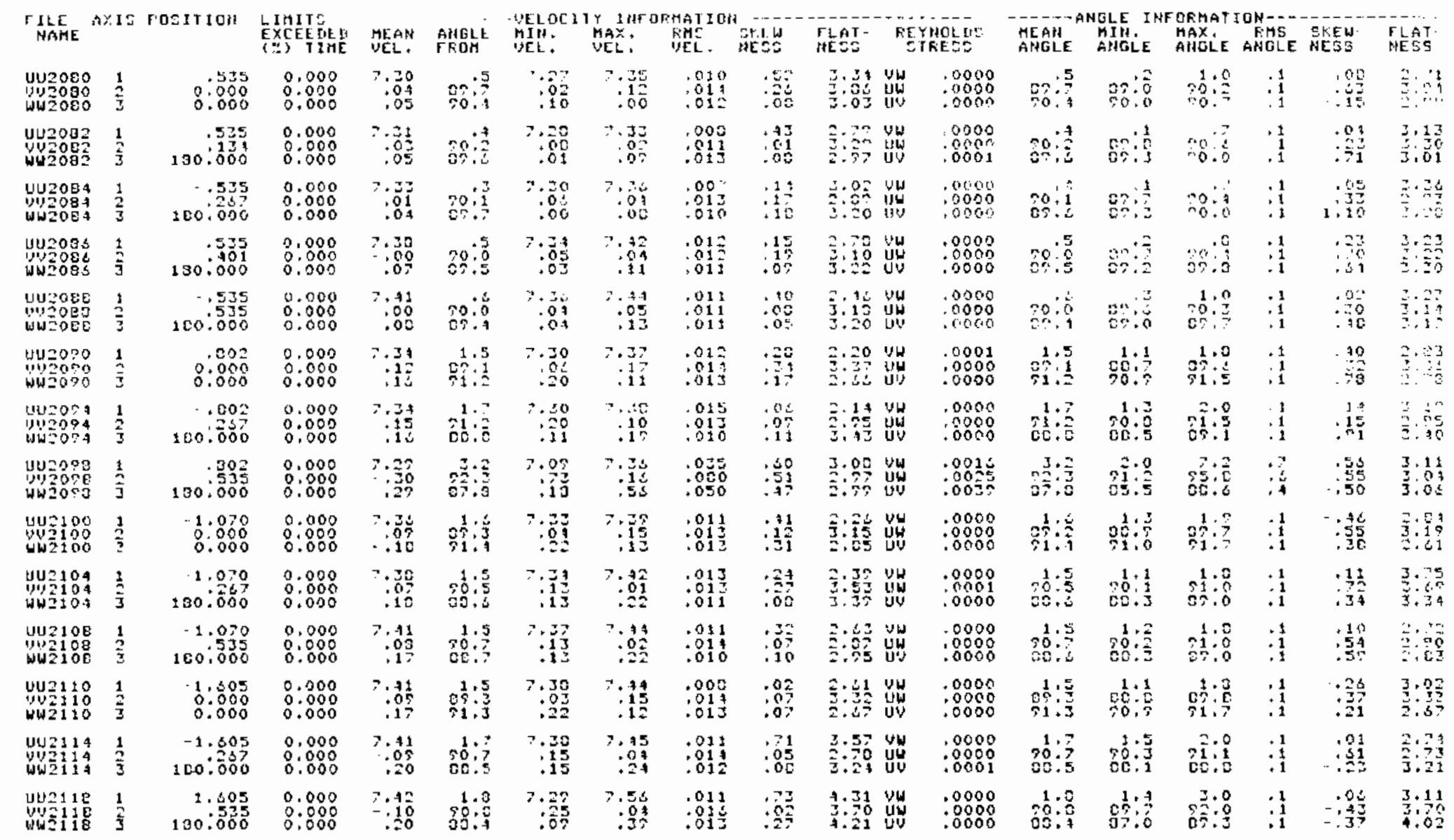

Note: $\bar{u}$ values are $2.5 \%$ low. 


\section{TABLE 3.3-3. (contd)}

\begin{tabular}{|c|c|c|c|c|c|c|c|c|c|c|c|c|c|c|c|c|c|}
\hline$n$ & & & CEE GIER & MEA & $\begin{array}{l}\text { AHGLLE } \\
\text { FFOH }\end{array}$ & 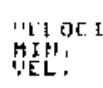 & MEL: & EĹ & 55 & FLAI- & $5 \frac{116}{5}$ & EANE & Nub & $\mathrm{HI}$ & $\begin{array}{l}\text { Sins } \\
\text { ANG }\end{array}$ & $B E$ & \\
\hline $\begin{array}{l}3091 \\
3001 \\
3001\end{array}$ & $\begin{array}{l}1 \\
3 \\
3\end{array}$ & 180.000 & $\begin{array}{l}.555 \\
1.5354\end{array}$ & $\begin{array}{l}5.55 \\
\cdots .90 \\
\cdots .90\end{array}$ & $\begin{array}{r}10.0 \\
580 \\
100: 8\end{array}$ & $\begin{array}{r}1.89 \\
1: 83 \\
-4: 4.5\end{array}$ & 列: & 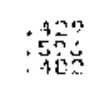 & $\begin{array}{l}2.80 \\
1.80\end{array}$ & 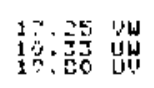 & 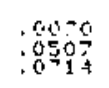 & 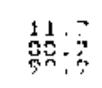 & $30: \frac{1}{2}$ & 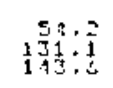 & $\begin{array}{l}5: \ddot{3} \\
\text { s: }\end{array}$ & 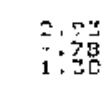 & \\
\hline 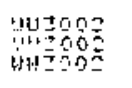 & $\frac{1}{3}$ & 100.000 & $\begin{array}{r}.006 \\
.095\end{array}$ & 年 & 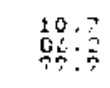 & 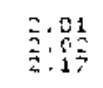 & 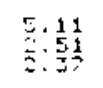 & 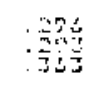 & 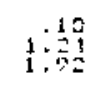 & 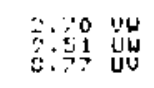 & $\begin{array}{l}.0170 \\
0702 \\
0207\end{array}$ & & 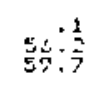 & 站: & $\begin{array}{l}1.1 \\
5: 0 \\
5: 0\end{array}$ & 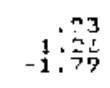 & \\
\hline $\begin{array}{l}300 \% \\
2003 \\
6007\end{array}$ & $\frac{1}{5}$ & $\begin{array}{r}0.00 \\
180.000\end{array}$ & $=: \begin{array}{l}011 \\
0.37\end{array}$ & $\begin{array}{l}2.79 \\
28 \% \\
3 \%\end{array}$ & $\begin{array}{r}13: 3 \\
130 \\
1020\end{array}$ & $\begin{array}{l}1 \\
1 \\
1 \\
1\end{array}$ & 1.53 & 年 & $\frac{20}{19}$ & 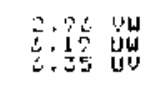 & $\begin{array}{l}.005 \\
.0151 \\
.0152\end{array}$ & $\begin{array}{r}135 \\
101 \\
101\end{array}$ & & $\begin{array}{l}11 \\
114 \\
12\end{array}$ & $\begin{array}{l}5: 0 \\
5 \\
5\end{array}$ & $\begin{array}{l}1: 12 \\
1: 18 \\
1: 25\end{array}$ & \\
\hline 505 & $\frac{1}{3}$ & 100. & $\begin{array}{l}0.000 \\
0.000 \\
0.000\end{array}$ & $\begin{aligned} 3.21 \\
3.25\end{aligned}$ & 离: & $\begin{array}{l}6.37 \\
0.15 \\
.42\end{array}$ & 泣 & 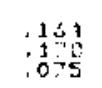 & $.1 \%$ & 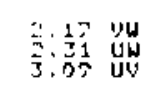 & $\begin{array}{l}.0003 \\
.0034\end{array}$ & 赵象 & & $\begin{array}{l}10.2 \\
01: 7 \\
95.1\end{array}$ & 落 & - & \\
\hline & $\frac{1}{3}$ & $\begin{array}{r}36 \\
100.000\end{array}$ & $\begin{array}{l}0.000 \\
8.000 \\
0.000\end{array}$ & 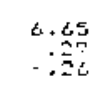 & 年: & 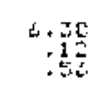 & & 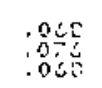 & .02 & & $\begin{array}{l}.0000 \\
.00001\end{array}$ & 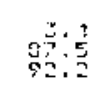 & & $\begin{array}{l}5 \\
21: 0 \\
2 \\
3 \\
3\end{array}$ & 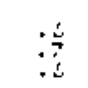 & $\begin{aligned} 02 \\
021\end{aligned}$ & \\
\hline 20 & $\frac{1}{1}$ & 1000 & $\begin{array}{l}2.000 \\
1800 \\
0.000\end{array}$ & 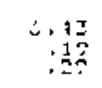 & 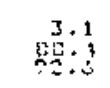 & $\begin{aligned} 617 \\
1 \\
150\end{aligned}$ & كُ. & $\begin{array}{l}.058 \\
: 075 \\
050\end{array}$ & $: 0$ & 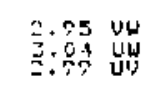 & $\begin{array}{r}.0001 \\
.0000 \\
.0005\end{array}$ & 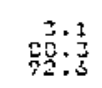 & & $\begin{array}{r}5.7 \\
r \frac{1}{2} \\
25: 2\end{array}$ & 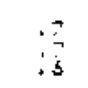 & $\begin{array}{l}.01 \\
.01 \\
0.06\end{array}$ & \\
\hline $\begin{array}{l}011 \\
011 \\
011\end{array}$ & $\frac{1}{\frac{1}{3}}$ & $\begin{array}{r}.131 \\
1800.020 \\
0.000\end{array}$ & $\begin{array}{r}.015 \\
.015 \\
.015 \\
.015\end{array}$ & $\begin{array}{l}5.31 \\
1: 01 \\
1: 01\end{array}$ & $\begin{array}{l}10.0 \\
500 \\
35: 0\end{array}$ & $\begin{array}{l}4.05 \\
3: 01 \\
2: 01\end{array}$ & 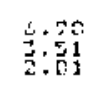 & 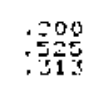 & $\begin{array}{l}1.00 \\
3.80 \\
1.80\end{array}$ & 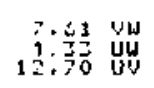 & $\begin{array}{l}.0005 \\
02070 \\
.079\end{array}$ & 竞: & & $\begin{array}{l}35: 9 \\
113: 0 \\
110: 0\end{array}$ & $\frac{5}{5}: 5$ & 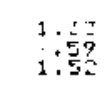 & \\
\hline 2912 & $\stackrel{1}{3}$ & $\begin{array}{r}1134 \\
100.135 \\
1000\end{array}$ & : 2.015 & 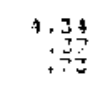 & 10:? & 说: & 告:14 & 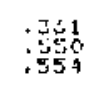 & 露 & 細 & 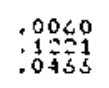 & 12.9 & & $\begin{array}{l}10.3 \\
120: 0 \\
120: 3\end{array}$ & $\begin{array}{l}5.9 \\
5: 3\end{array}$ & $\begin{array}{r}1.50 \\
1.05 \\
-2.16\end{array}$ & \\
\hline b) 1 & $\frac{1}{3}$ & $\begin{array}{r}.334 \\
180.00 \%\end{array}$ & 年 & \begin{tabular}{l}
$\because 81$ \\
$\because 80$ \\
\hdashline 11
\end{tabular} & $\begin{array}{rl}15 & \\
52 & 0 \\
101 & 0\end{array}$ & 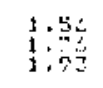 & 当: & 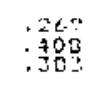 & 2 & 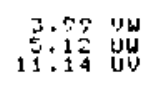 & $\begin{array}{l}.0950 \\
0975 \\
0205\end{array}$ & 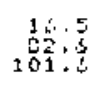 & & $\begin{array}{r}71,0 \\
124 \\
125: 5\end{array}$ & $\stackrel{5}{8}:: \frac{5}{9}$ & 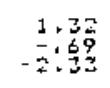 & \\
\hline$\$ 1$ & $\frac{1}{3}$ & 100.000 & $\begin{array}{l}0.600 \\
0.000 \\
0.000\end{array}$ & 28 & $\begin{array}{l}8.8 \\
81: 5 \\
9\end{array}$ & 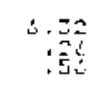 & $\begin{array}{l}3: 07 \\
1: 07 \\
07\end{array}$ & $\begin{array}{l}10 \% \\
: 195 \\
: 09\end{array}$ & 01 & vun & $\begin{array}{l}: 0014 \\
: 007\end{array}$ & 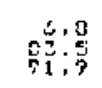 & & 然: & $\begin{array}{l}1.2 \\
1: 2 \\
; 0\end{array}$ & $\begin{array}{r}-.03 \\
.02 \\
.02\end{array}$ & \\
\hline की & $\frac{1}{5}$ & $\begin{array}{r}.134 \\
100.800\end{array}$ & $\begin{array}{l}0.000 \\
3.000 \\
0.000\end{array}$ & $\begin{array}{r}t .50 \\
-758 \\
-158\end{array}$ & $\begin{array}{r}5.3 \\
\underset{05}{5}: 1 \\
9: 0\end{array}$ & 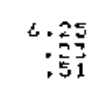 & $\begin{array}{r}4.7 \\
.05\end{array}$ & $\begin{array}{l}.070 \\
.060 \\
062\end{array}$ & .05 & 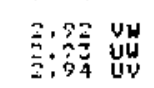 & $\begin{array}{l}.0054 \\
.0002\end{array}$ & 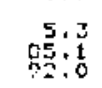 & & 是: & $: 7$ & & \\
\hline & $\stackrel{1}{2}$ & $100 . \begin{array}{r}157 \\
25050\end{array}$ & $\begin{array}{l}0.000 \\
0.000 \\
0.000\end{array}$ & $\begin{aligned} \therefore: 30 \\
: 31 \\
: 25\end{aligned}$ & 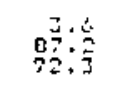 & 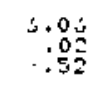 & $\begin{aligned} 6.80 \\
: 50 \\
10\end{aligned}$ & $\begin{array}{l}049 \\
08 \% 5 \\
0 \% 5\end{array}$ & & 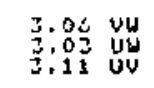 & $\begin{array}{r}.0001 \\
.000 \% \\
.0007\end{array}$ & $\begin{array}{l}3: 7 \\
32 \\
3: 3\end{array}$ & & $\begin{array}{l}3.5 \\
90: 5 \\
94: 7\end{array}$ & $: ?$ & $\begin{array}{l}-.05 \\
-: 10 \\
-: 10\end{array}$ & \\
\hline 102 & $\frac{1}{3}$ & $\begin{array}{r}80 \% \\
180.000\end{array}$ & $\begin{array}{l}: 071 \\
: 974 \\
2.75\end{array}$ & $\begin{array}{r}5.75 \\
-1.08 \\
-1.08 \\
4\end{array}$ & $\begin{array}{r}11: 5 \\
85: 5 \\
100: 6\end{array}$ & $\begin{array}{r}3 \\
-\frac{3}{3}: 52 \\
-3: 04\end{array}$ & 登: 100 & $\begin{array}{l}: 20 \mathrm{e} \\
: 305 \\
: 478\end{array}$ & $\begin{array}{r}17 \\
2: 07 \\
2: 51\end{array}$ & 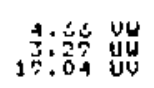 & $\begin{array}{l}0240 \\
0.0290 \\
0.0005\end{array}$ & $\begin{array}{rl}15 & 07 \\
100 & 0 \\
100\end{array}$ & & $\begin{array}{r}35: 5 \\
125: 7 \\
119\end{array}$ & $\begin{array}{l}3: 5 \\
5: 5 \\
4: 8 \\
7\end{array}$ & $\begin{array}{l}1.54 \\
2: 13 \\
2: 74\end{array}$ & \\
\hline & $\stackrel{1}{\vdots}$ & $180: \begin{array}{r}05 \\
050 \\
150\end{array}$ & $2: 307$ & $\begin{array}{r}+.94 \\
+914 \\
: 913\end{array}$ & 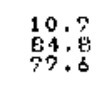 & & $\begin{array}{l}4: 39 \\
4: 97\end{array}$ & $\begin{array}{l}: 372 \\
: 180 \\
: 71\end{array}$ & 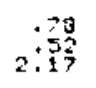 & 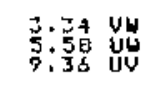 & $\begin{array}{r}\because 0030 \\
\because 1209 \\
: 0503\end{array}$ & $\begin{array}{l}15.5 \\
64: 5 \\
59: 4\end{array}$ & & $\begin{array}{l}41: 7 \\
120: 1 \\
123: 9\end{array}$ & $\begin{array}{l}5.9 \\
9: 2\end{array}$ & $\begin{array}{r}1: 83 \\
-2: \frac{32}{24} \\
-2\end{array}$ & \\
\hline 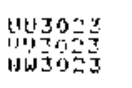 & $\frac{1}{5}$ & $\begin{array}{r}.087 \\
0.80 \\
180.000\end{array}$ & 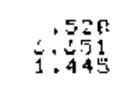 & $\begin{array}{l}3.12 \\
-: 55 \\
-85\end{array}$ & 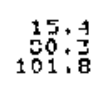 & 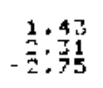 & $\frac{5}{3}: \frac{2}{2}=\frac{1}{\hat{t}}$ & 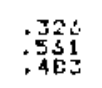 & $\begin{aligned} .44 \\
2: 00 \\
: 30\end{aligned}$ & 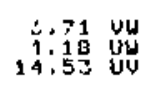 & $\begin{array}{l}.0951 \\
0.0077 \\
.0072\end{array}$ & $\begin{array}{r}158: 3 \\
150: 0 \\
101: 0\end{array}$ & $42: \begin{array}{l}4 \\
5 \\
5\end{array}$ & 竞: & $\begin{array}{l}3 \\
9: 1 \\
\mathrm{E}:\end{array}$ & $\begin{array}{l}3: 2 z \\
2: 1 \frac{2}{7} \\
2: 17\end{array}$ & \\
\hline
\end{tabular}

Note: velocity values are possibly 3\% low. 
TABLE 3.3-3. (contd)

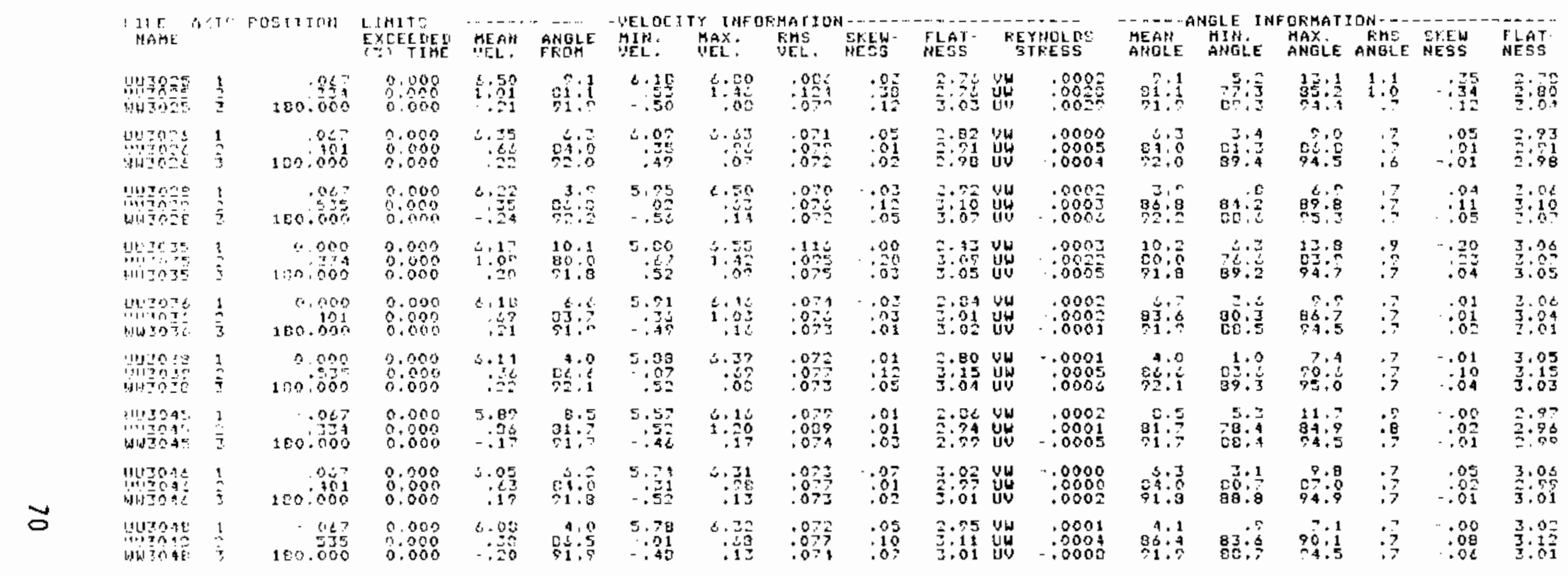

Note: $\bar{u}$ values are possibly $3 \%$ low. 
TABLE 3.3-3. (contd)

\begin{tabular}{|c|c|c|c|c|c|c|c|c|c|c|c|c|c|c|c|c|c|}
\hline 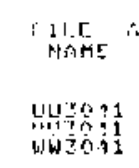 & \multicolumn{2}{|c|}{ 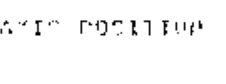 } & \multirow{2}{*}{ 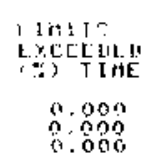 } & \multirow{2}{*}{ 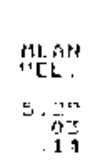 } & \multirow{2}{*}{ 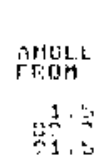 } & 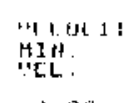 & 4 & 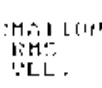 & 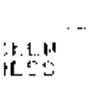 & \multicolumn{2}{|l|}{ I t:i, } & \multicolumn{6}{|c|}{ 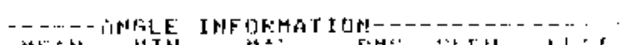 } \\
\hline 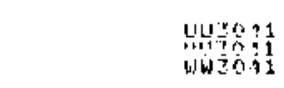 & $\frac{1}{5}$ & +co.000 & & & & $\begin{array}{r}1.28 \\
: 19 \\
19\end{array}$ & $5 \cdot 49$ & $\begin{array}{l}\cdot 115 \\
.125\end{array}$ & 89 & 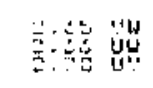 & . & 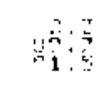 & 85 & 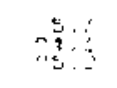 & $\stackrel{1}{1}$ & d. & 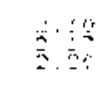 \\
\hline 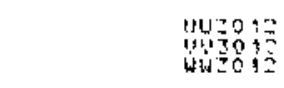 & $\stackrel{1}{7}$ & $\begin{array}{r}.05: 5 \\
100.000\end{array}$ & $\begin{array}{l}0.090 \\
0: 000 \\
0.000\end{array}$ & $\begin{array}{r}5,1 \% \\
.11\end{array}$ & $\frac{2}{2}$ & 1. & $5 \cdot 2$ & 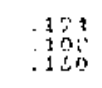 & $\begin{array}{ll}1 \\
20\end{array}$ & 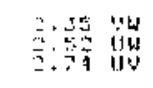 & 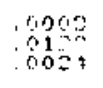 & 幖 & (5: & 年 & $\begin{array}{l}1,0 \\
1.0 \\
1.0\end{array}$ & & 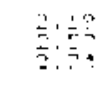 \\
\hline 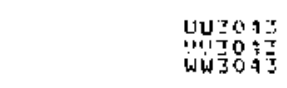 & $\frac{1}{2}$ & $\begin{array}{r}.051 \\
100.000\end{array}$ & $\begin{array}{l}0.000 \\
8: 000 \\
0.000\end{array}$ & $\begin{array}{rl}5 & 20 \\
: 00 \\
0\end{array}$ & 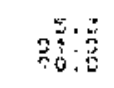 & $\$$ & s. & 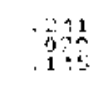 & 12 & 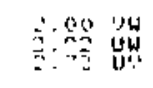 & 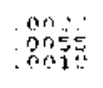 & $\begin{array}{ll}5 \\
5 \\
0\end{array}$ & a & is & $1: 0$ & $\begin{array}{l}1 \\
1 \\
\vdots \\
\vdots\end{array}$ & \\
\hline 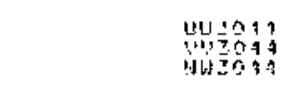 & $\frac{1}{2}$ & 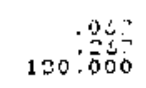 & $\begin{array}{l}0.000 \\
0.000 \\
0.000\end{array}$ & $\begin{aligned} 5.52 \\
.02\end{aligned}$ & $\frac{2}{20}$ & & 我: & $\begin{array}{l}10 \% \\
.625\end{array}$ & $\begin{array}{r}11 \\
11 \\
25\end{array}$ & 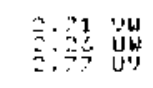 & 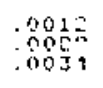 & 80 & 0 & 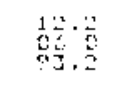 & $1 \cdot \frac{1}{1}$ & 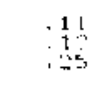 & 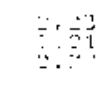 \\
\hline 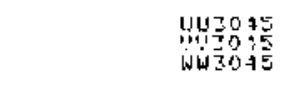 & $\frac{1}{3}$ & 100:000 & $\begin{array}{l}0.000 \\
0.000 \\
0.000\end{array}$ & $\therefore \frac{1}{5}$ & 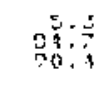 & & $\therefore$ & $\begin{array}{l}.80 \\
.065\end{array}$ & $\begin{array}{l}.01 \\
0.5 \\
.0 .1\end{array}$ & 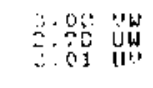 & $\begin{array}{l}.0002 \\
.000 \% \\
.0009\end{array}$ & 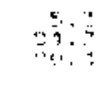 & 站 & 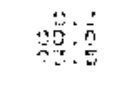 & 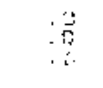 & 8 & $\therefore$ \\
\hline 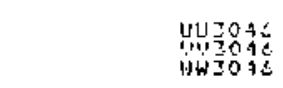 & $\frac{1}{2}$ & $\begin{array}{r}9 \% 91 \\
130.000\end{array}$ & $\begin{array}{l}0.000 \\
0.000 \\
0.000\end{array}$ & t.:5 & $\begin{array}{l}3.3 \\
8: 020\end{array}$ & $=8$ & $\begin{aligned} \therefore .59 \\
\therefore=0\end{aligned}$ & $\begin{array}{l}.0 \% \\
.06\end{array}$ & $.89 \frac{2}{81}$ & 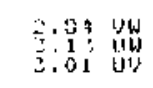 & $\begin{array}{l}.6001 \\
.6005 \\
0001\end{array}$ & 起: & : & 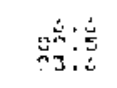 & $\begin{array}{l}\vdots \\
\therefore\end{array}$ & 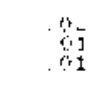 & $1 \frac{1}{2}$ \\
\hline 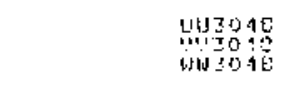 & $\frac{1}{3}$ & 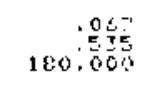 & $\begin{array}{l}0.000 \\
0.000 \\
0.000\end{array}$ & 注 & 产: & & & 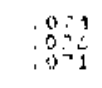 & 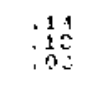 & 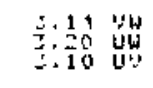 & $\begin{array}{l}.090 \% \\
.0000\end{array}$ & 焉: & $39:$ & 辛: & 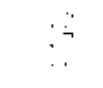 & 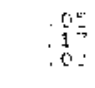 & \\
\hline 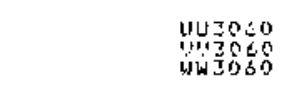 & $\frac{1}{3}$ & $\begin{array}{l}.139 \\
0.000 \\
0.0000\end{array}$ & $\begin{array}{l}0.000 \\
0.000 \\
0.000\end{array}$ & $\begin{array}{r}5.71 \\
.04 \\
.10\end{array}$ & 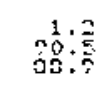 & 5.10 & 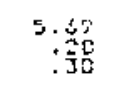 & .023 & $\begin{array}{l}.00 \\
.01 \\
.09\end{array}$ & 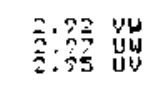 & $\begin{array}{l}.0001 \\
.00050 \\
00003\end{array}$ & $\begin{array}{l}1.5 \\
00 \\
0.5\end{array}$ & 28 & 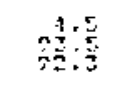 & 80 & 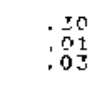 & $\begin{array}{l}2.84 \\
2,96\end{array}$ \\
\hline 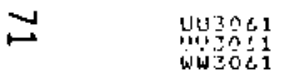 & $\frac{1}{3}$ & $\begin{array}{r}r \\
180.000\end{array}$ & $\begin{array}{l}8.000 \\
8000 \\
0.000\end{array}$ & 5.10 & 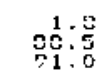 & 3.00 & 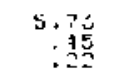 & $\begin{array}{r}80 \\
.085 \\
0001\end{array}$ & 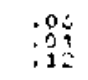 & 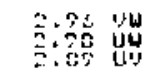 & $\begin{array}{r}.0002 \\
.0810 \\
.000 \%\end{array}$ & 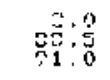 & $.05 \cdot 9$ & n: & 晒 & $: \frac{11}{0}$ & \\
\hline 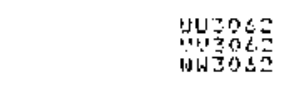 & $\frac{1}{5}$ & $100: 000$ & $\begin{array}{l}0.000 \\
0.000 \\
0.000\end{array}$ & $\begin{array}{r}5.45 \\
203 \\
0 \%\end{array}$ & 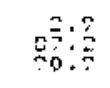 & 5.87 & $5: 89$ & $\begin{array}{l}104 \\
.09 \\
.0 \% 0\end{array}$ & $\begin{array}{l}0 \\
0 \\
0 \\
0 \\
0 \\
11\end{array}$ & 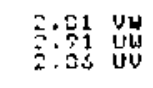 & $\begin{array}{l}.0003 \\
8029 \\
0002\end{array}$ & 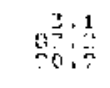 & & 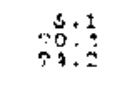 & : & .0 & \\
\hline 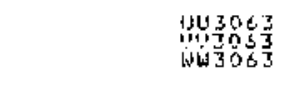 & $\frac{1}{3}$ & $100.00 \%$ & $\begin{array}{l}0.800 \\
0.000 \\
0.000\end{array}$ & $\begin{array}{r}5.57 \\
.06 \\
.06\end{array}$ & 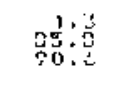 & 5.10 & 5.5 & $\begin{array}{l}112 \\
0.040 \\
0006\end{array}$ & $\begin{array}{l}80 \\
01 \\
: 11\end{array}$ & 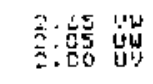 & $\begin{array}{r}0002 \\
00011 \\
.0001\end{array}$ & 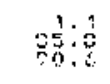 & $\frac{3}{3}$ & 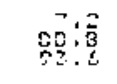 & 0 & $: 03$ & \\
\hline 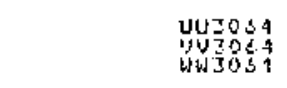 & $\frac{1}{3}$ & 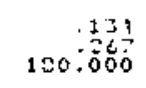 & $\begin{array}{l}0.000 \\
0.000 \\
0.000\end{array}$ & $\begin{array}{r}5.80 \\
: 50 \\
.03\end{array}$ & $\begin{array}{l}1: ? \\
90\end{array}$ & $\begin{array}{r}5.51 \\
: \begin{array}{l}51 \\
: 31\end{array}\end{array}$ & $\begin{array}{l}4: 12 \\
: 032\end{array}$ & $\begin{array}{l}.008 \\
.085\end{array}$ & $\begin{array}{l}04 \\
: 04 \\
: 01\end{array}$ & 产: & $\begin{array}{r}.0002 \\
.0015 \\
.0001\end{array}$ & 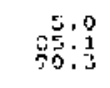 & $\tilde{\tilde{i}}$ & 落: & : & $\begin{array}{r}.02 \\
.92 \\
.10\end{array}$ & \\
\hline $\begin{array}{l}\text { uyzots } \\
\text { Wy,3065 } \\
\text { WW } \\
\text { W }\end{array}$ & $\frac{1}{2}$ & $\begin{array}{r}-134 \\
1800,000 \\
334\end{array}$ & $\begin{array}{l}0.000 \\
0.000 \\
0.000\end{array}$ & $\begin{array}{r}6.02 \\
35 \\
-.04\end{array}$ & 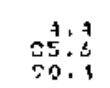 & $\begin{array}{r}5.72 \\
0.35 \\
3\end{array}$ & 崚 & $\begin{array}{l}.037 \\
.075\end{array}$ & $\begin{array}{l}.85 \\
.01 \\
.05\end{array}$ & 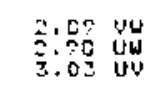 & $\begin{array}{l}.0002 \\
00003 \\
.0002\end{array}$ & 年: & $8=\frac{1}{5}$ & 放: & $\because$ & .0 & \\
\hline $\begin{array}{l}\text { yuzoss } \\
\text { wy } \\
\text { whos }\end{array}$ & $\frac{1}{\frac{3}{3}}$ & $\begin{array}{r}.13 \% \\
130: 0000\end{array}$ & $\begin{array}{l}0.000 \\
0.000 \\
0.000\end{array}$ & $\begin{array}{r}5.14 \\
: 0 \% \\
.020\end{array}$ & $\begin{array}{l}3.0 \\
50: 0 \\
7\end{array}$ & $\begin{array}{r}5.87 \\
: 03 \\
07\end{array}$ & 4.:4 & $\begin{array}{l}075 \\
: 070 \\
071\end{array}$ & $\begin{array}{l}.05 \\
0.1 \\
01 \\
01\end{array}$ & 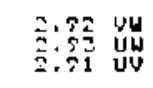 & $\begin{array}{l}.0002 \\
: 0005 \\
.0001\end{array}$ & 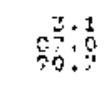 & 0.9 & 总: & $\frac{7}{7}$ & $\begin{array}{l}94 \\
04 \\
01 \\
01\end{array}$ & \\
\hline 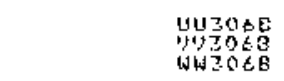 & $\frac{1}{3}$ & $\begin{array}{r}r 535 \\
100.000\end{array}$ & $\begin{array}{l}0.000 \\
0: 000 \\
0.000\end{array}$ & 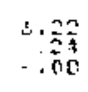 & 管: & S.? & 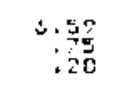 & $\begin{array}{r}075 \\
075 \\
072 \\
075\end{array}$ & 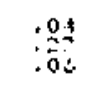 & 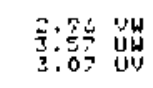 & $\begin{array}{l}: 000 \% \\
: 0001 \\
0003\end{array}$ & 年: & $8: \frac{9}{5}$ & 岳: & $: \frac{7}{7}$ & $\begin{array}{l}97 \\
.07 \\
.05\end{array}$ & 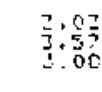 \\
\hline
\end{tabular}


TABLE 3.3-3. (contd)

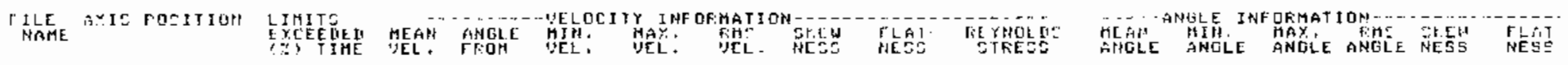

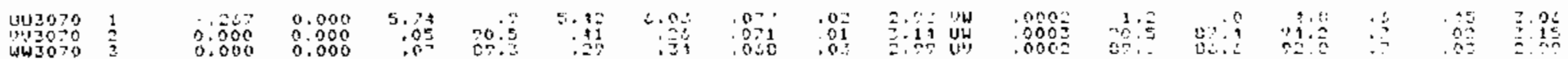

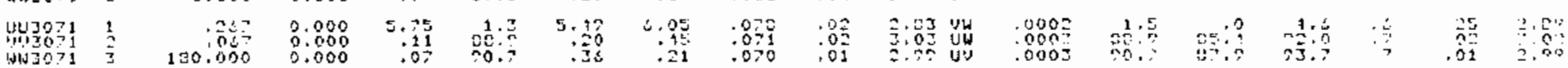

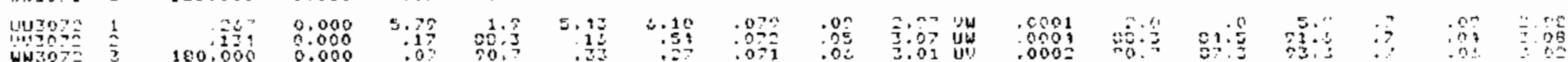

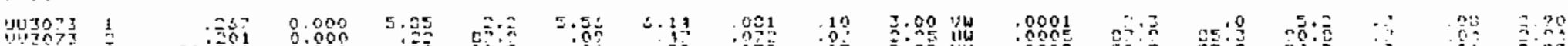

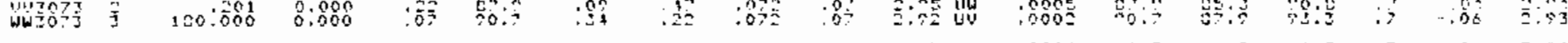

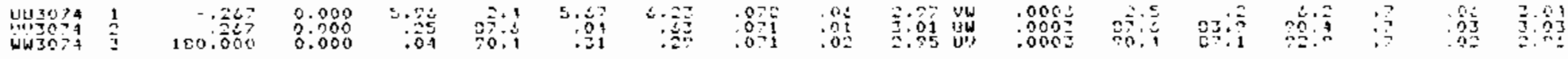

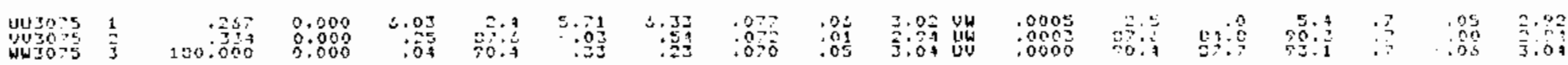

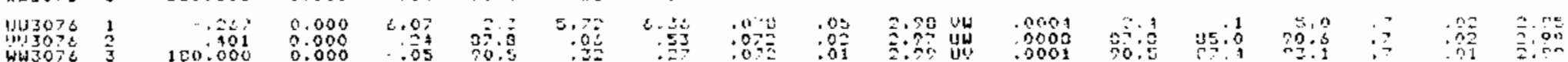

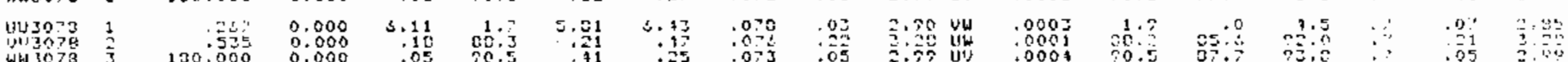




\section{TABLE 3.3-3. (contd)}

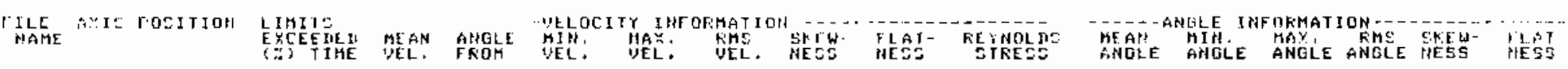

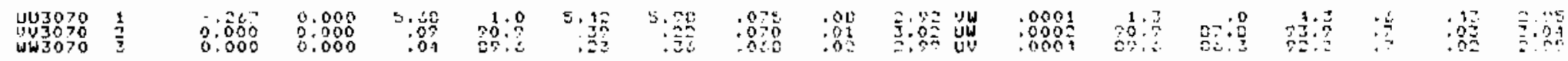

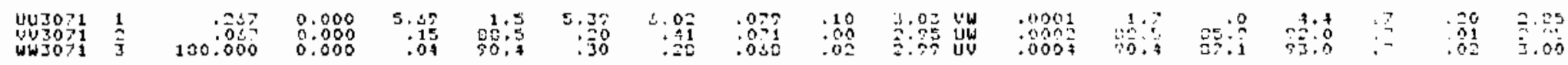

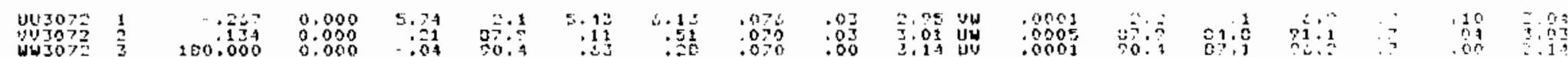

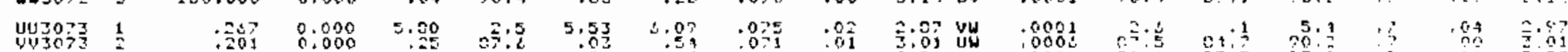

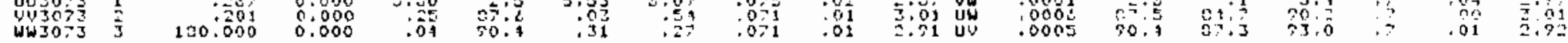

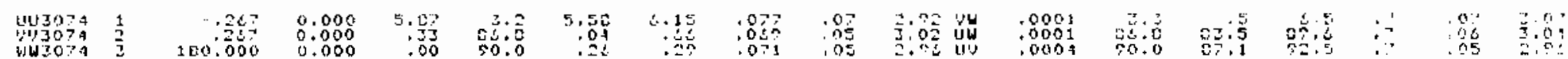

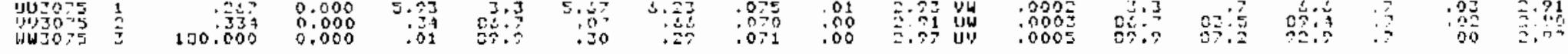

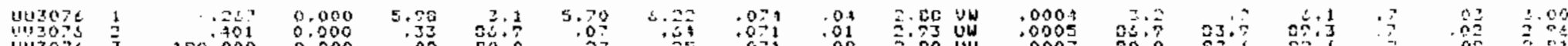

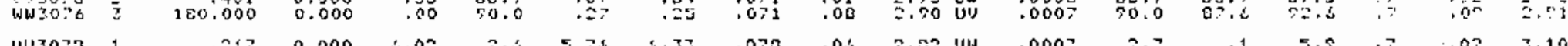

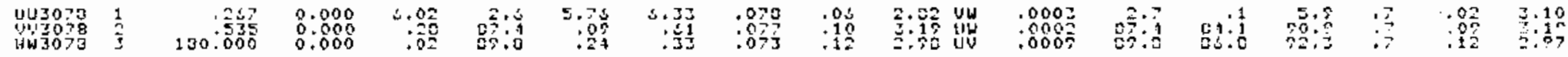

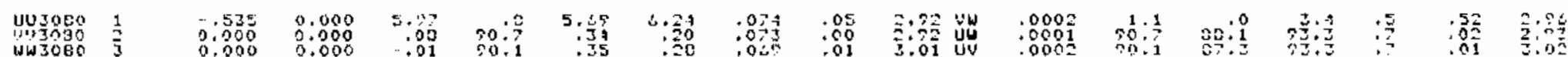

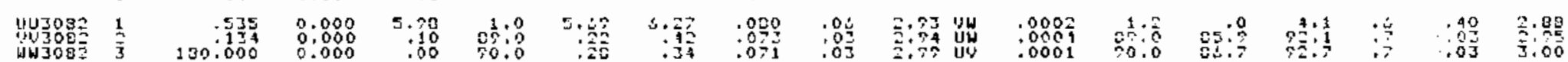

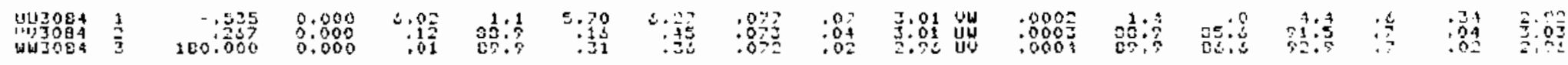

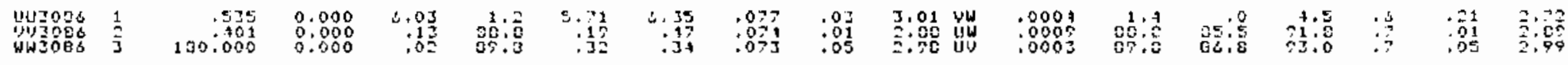

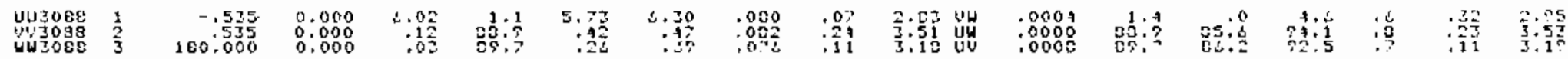

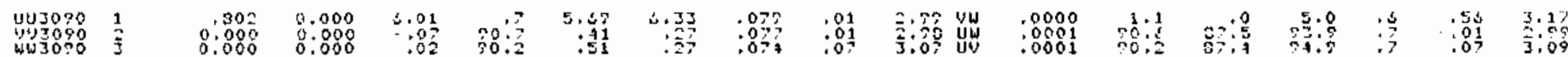

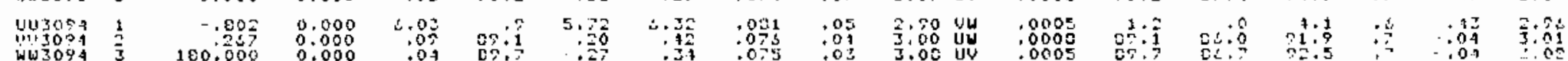


TABLE 3.3-3. (contd)

\begin{tabular}{|c|c|c|c|c|c|c|c|c|c|c|c|c|c|c|c|c|}
\hline 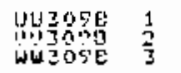 & 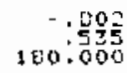 & $\begin{array}{l}0.000 \\
0: 0000 \\
0.0000\end{array}$ & $\begin{array}{r}4: 00 \\
: 05 \\
: 05\end{array}$ & $\begin{array}{c}1 \\
5: 1 \\
87 \\
8\end{array}$ & 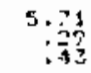 & 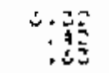 & $\begin{array}{l}: 009 \\
: 007 \\
: 07 \\
07\end{array}$ & : & 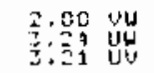 & $\begin{array}{l}6000 \\
00000 \\
0000\end{array}$ & 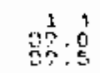 & 暍: & 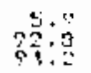 & 凅 & $\begin{array}{l}3 \\
1 \% \\
10\end{array}$ & \\
\hline$\frac{1}{3}$ & $\begin{array}{rl}1 & 0 \% 0 \\
0 & 0.008 \\
0.000\end{array}$ & $\begin{array}{l}0: 080 \\
0.000 \\
0.000\end{array}$ & $\begin{array}{r}3.04 \\
0.05 \\
0.05\end{array}$ & $30: \frac{8}{4}$ & 汭 & 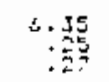 & $\begin{array}{l}.092 \\
092 \\
075 \\
075\end{array}$ & 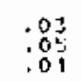 & 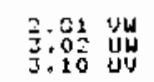 & $\begin{array}{l}0002 \\
: 000 \\
: 0003\end{array}$ & 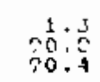 & $\frac{9}{0}$ & 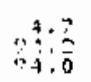 & : & & \\
\hline$\frac{\frac{1}{2}}{2}$ & $\begin{array}{r}1.078 \\
180.006\end{array}$ & $\begin{array}{l}0.000 \\
0.000 \\
0.0000\end{array}$ & $\begin{array}{c}6.07 \\
0.07 \\
05\end{array}$ & $\frac{1}{8}: \frac{0}{2}$ & 资: & 啡 & $\begin{array}{l}.007 \\
: 007 \\
: 077\end{array}$ & $\begin{array}{l}11 \\
: 01 \\
02 \\
02\end{array}$ & $\Xi: \%$ & 000 & $\begin{array}{l}\frac{1}{2}: 5 \\
0 \\
0\end{array}$ & $85: \frac{\hat{3}}{3}$ & 㱐: & : & & \\
\hline & $\begin{array}{r}1,8920 \\
130,0000\end{array}$ & $\begin{array}{l}0.000 \\
0: 000 \\
0: 000\end{array}$ & $\begin{array}{r}2.01 \\
: 00 \\
: 07\end{array}$ & $\begin{array}{c}\frac{1}{2}: 0 \\
2: 0 \\
3\end{array}$ & 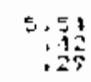 & 6.35 & 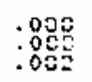 & $\begin{array}{l}: 11 \\
: \begin{array}{l}11 \\
08\end{array}\end{array}$ & 3.094 & $\begin{array}{l}0006 \\
0000 \\
00006\end{array}$ & $1: \frac{3}{3}$ & 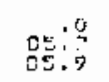 & 1.5 & 渗 & & \\
\hline & $\begin{array}{r}-1.050 \\
0 \% 000 \\
0.000\end{array}$ & $\begin{array}{l}0.000 \\
0: 000 \\
0: 000\end{array}$ & $\begin{array}{l}2.06 \\
: 05 \\
05\end{array}$ & $\begin{array}{l}1 \\
30: 8 \\
30: 0\end{array}$ & 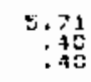 & 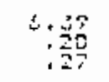 & $\begin{array}{l}.000 \\
: 809 \\
.057\end{array}$ & $\begin{array}{l}: 05 \\
: 085 \\
: 05\end{array}$ & & $\begin{array}{l}0003 \\
: 0000 \\
0002\end{array}$ & $\begin{array}{lll}1 & 1 \\
3 & 0 \\
3 & 0\end{array}$ & : & 84 & : & & \\
\hline & $\begin{array}{r}1.055 \\
100.0 \% 0\end{array}$ & 0.000 & $\begin{array}{r}5.07 \\
0.00 \\
000\end{array}$ & $\begin{array}{ll}1,1 \\
3 \\
3\end{array}$ & s.45 & 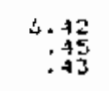 & 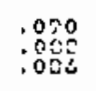 & 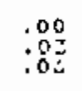 & & 0005 & 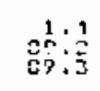 & 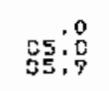 & 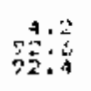 & : & 08 & \\
\hline & $\begin{array}{l}-1,605 \\
180,505 \\
0.000\end{array}$ & $\begin{array}{l}0.000 \\
0.000 \\
0.000\end{array}$ & 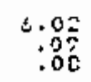 & $\frac{1}{25}: \frac{2}{2}$ & 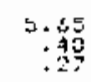 & 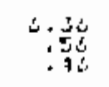 & $\begin{array}{l}0 \%= \\
: 089 \\
000\end{array}$ & 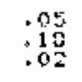 & 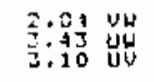 & $\begin{array}{l}: 0000 \\
: 0001 \\
: 000 \%\end{array}$ & 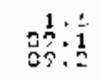 & sis & 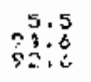 & : & $\begin{array}{l}30 \hat{3} \\
02 \\
02\end{array}$ & \\
\hline
\end{tabular}




\section{TABLE 3.3-3. (contd)}

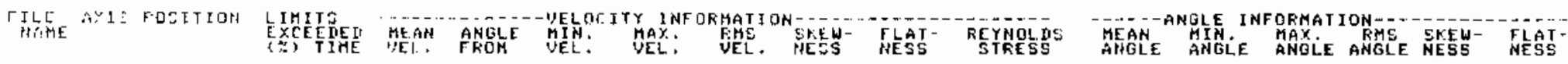

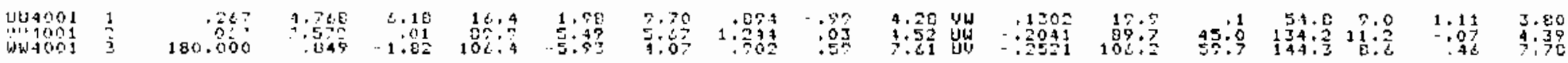

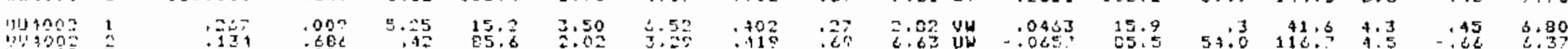
औ.

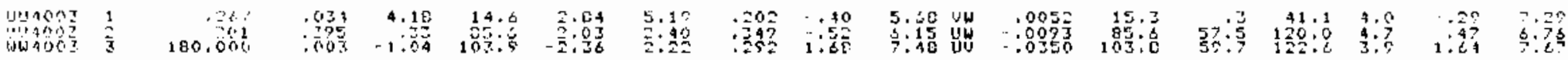

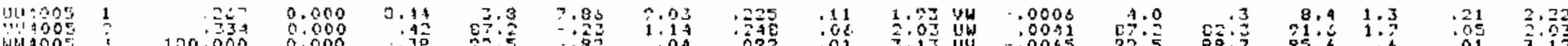

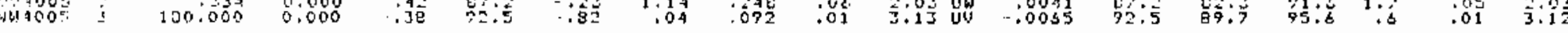

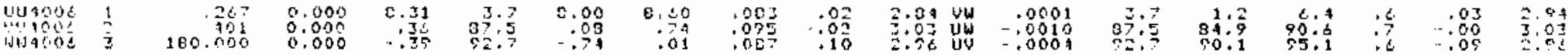

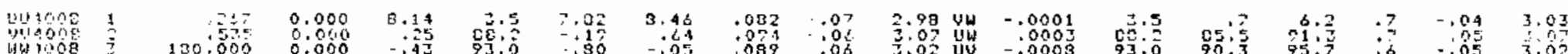

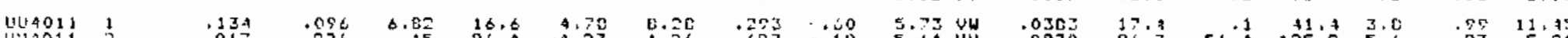

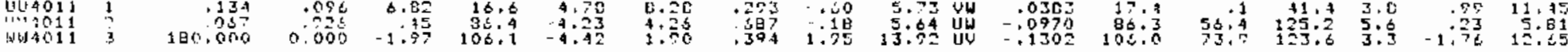

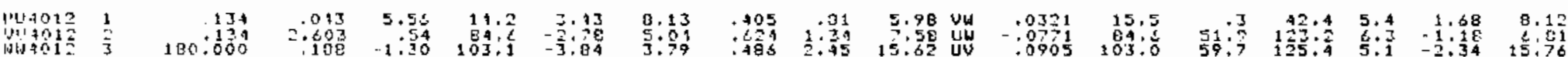

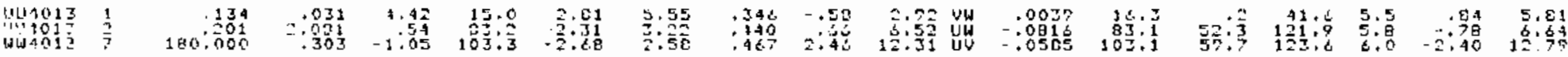

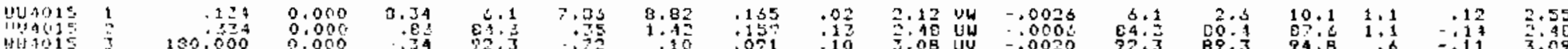

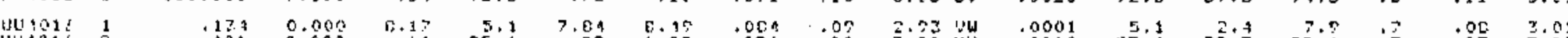

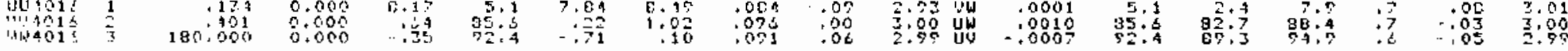

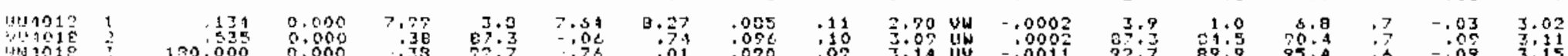

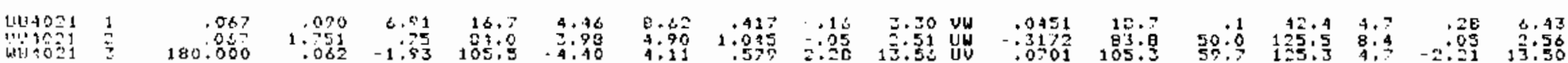

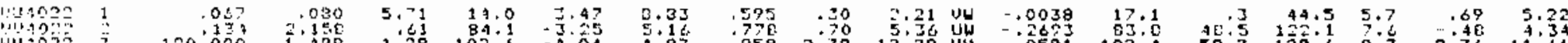

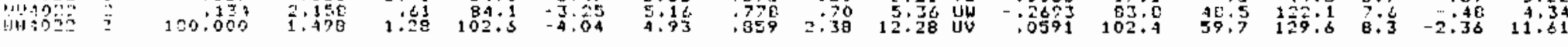

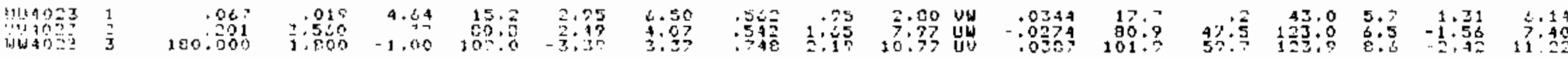

Note: velocity values are possibly $2.5^{\circ}$ low. 


\section{TABLE $3.3-3$. (contd)}

\begin{tabular}{|c|c|c|c|c|c|c|c|c|c|c|c|c|c|c|c|c|c|}
\hline SAME & & & 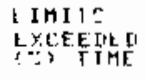 & MEAH' & $\begin{array}{l}\text { AHGGE } \\
\text { PROH }\end{array}$ & $\begin{array}{l}\text { MIN: } \\
\text { MEL: }\end{array}$ & Me日: & 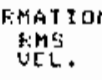 & SKEW- & $\begin{array}{l}\text { KLAI- } \mathrm{FE} \\
\mathrm{HESS}\end{array}$ & EStes & $\begin{array}{l}\text { MEAH } \\
\text { AMGLE }\end{array}$ & $\begin{array}{l}\text { NGEF IN } \\
\text { AIA } \\
\text { ANGLE }\end{array}$ & $\begin{array}{l}\text { MAX' } \\
\text { MAOLE }\end{array}$ & $\begin{array}{l}\text { RME } \\
\text { ANGLE }\end{array}$ & $\begin{array}{l}\text { SEUW } \\
\text { NESS }\end{array}$ & $\begin{array}{l}\text { FLAT } \\
\text { NESS }\end{array}$ \\
\hline 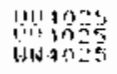 & $\begin{array}{l}1 \\
\vdots \\
3\end{array}$ & $\begin{array}{r}06 \\
100000\end{array}$ & $\begin{array}{l}0.900 \\
8.000 \\
0.000\end{array}$ & $\begin{array}{l}8: 15 \\
1: 05\end{array}$ & 等: & 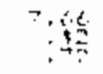 & 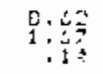 & : & 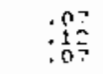 & 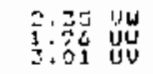 & $\begin{array}{l}.0045 \\
0005 \\
0005\end{array}$ & $\frac{9}{2}: \frac{3}{8}$ & 党: & $\begin{array}{l}\frac{12}{3}: \frac{2}{1} \\
\frac{8}{5}: \frac{1}{2}\end{array}$ & $1: 8$ & $\begin{array}{l}-1 \% \\
-: 15 \\
-12\end{array}$ & 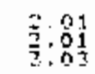 \\
\hline 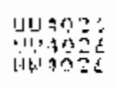 & $\frac{1}{\hat{3}}$ & $\begin{array}{r}50 \\
+00000\end{array}$ & $\begin{array}{l}0.000 \\
0.000 \\
0.000\end{array}$ & $\begin{array}{r}0.01 \\
: 0 \\
0\end{array}$ & 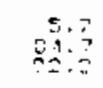 & 3 & $\begin{array}{l}3.37 \\
1.10 \\
?\end{array}$ & $\begin{array}{r}087 \\
10 \% \\
-090\end{array}$ & $\begin{array}{l}.02 \\
0 \% 5 \\
010\end{array}$ & 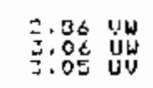 & $\begin{array}{l}0001 \\
00010 \\
0000\end{array}$ & 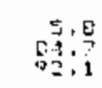 & $\begin{array}{l}3.0 \\
89: 3 \\
89\end{array}$ & $\begin{array}{r}8.8 \\
97.8\end{array}$ & $\because ?$ & $\begin{array}{r}.05 \\
-.09 \\
-.09\end{array}$ & 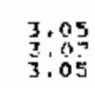 \\
\hline 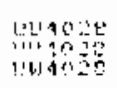 & $\underset{1}{1}$ & 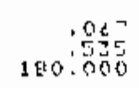 & $\begin{array}{l}0.800 \\
8.000 \\
0.000\end{array}$ & $\begin{array}{r}7.50 \\
734 \\
-114\end{array}$ & 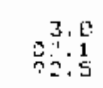 & $\begin{array}{l}7.57 \\
05\end{array}$ & $\begin{array}{r}0.22 \\
.05 \\
.05\end{array}$ & $\begin{array}{l}.007 \\
: 087 \\
0 \\
0\end{array}$ & $\begin{array}{l}.97 \\
.07 \\
.07\end{array}$ & $\begin{array}{l}3.02 \\
3 \\
3 \\
3 \\
3\end{array}$ & $\begin{array}{r}0000 \\
0000 \\
00010\end{array}$ & 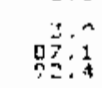 & $83: 7$ & $70: 4$ & $: 7$ & .0e & $\begin{array}{l}\frac{3}{3} \cdot 1.5 \\
3: 05\end{array}$ \\
\hline 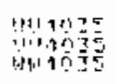 & $\frac{1}{3}$ & 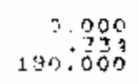 & $\begin{array}{l}9.000 \\
0.000 \\
0.000\end{array}$ & 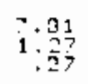 & $\begin{array}{ll}0 \\
0\end{array}$ & 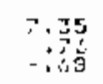 & $\begin{array}{l}0.70 \\
1.0 \\
10\end{array}$ & $\begin{array}{l}152 \\
: 152 \\
0254\end{array}$ & $\begin{aligned} .09 \\
-18 \\
0.05\end{aligned}$ & 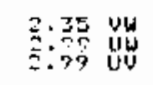 & $\begin{array}{l}: 0017 \\
: 0005 \\
0005\end{array}$ & 辛: & $\begin{array}{c}5: 9 \\
39 \\
39 \\
3\end{array}$ & 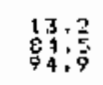 & $: ?$ & 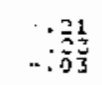 & 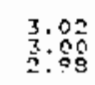 \\
\hline 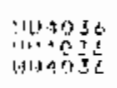 & $\frac{1}{3}$ & $\begin{array}{r}0.000 \\
+80.000\end{array}$ & $\begin{array}{l}0.006 \\
0.000 \\
0.000\end{array}$ & $\begin{array}{l}788 \\
: 31 \\
: 29\end{array}$ & $\begin{array}{l}4.3 \\
0.13 \\
0\end{array}$ & $\begin{array}{r}7.98 \\
-.45 \\
-25\end{array}$ & 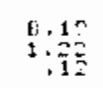 & $\begin{array}{r}.071 \\
.875 \\
070\end{array}$ & $\begin{array}{l}.07 \\
.01 \\
.05\end{array}$ & 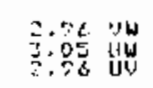 & $\begin{array}{r}.0001 \\
\therefore 0011 \\
.0001\end{array}$ & 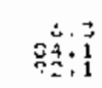 & $8 \begin{array}{l}2: ? \\
0\end{array}$ & 照勇: & : & $\begin{array}{r}.80 \\
.85 \\
04\end{array}$ & 光:0 \\
\hline 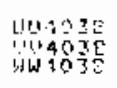 & $\begin{array}{l}3 \\
\dot{j}\end{array}$ & $\begin{array}{r}0.5 \% 0 \\
190.5 \% 50\end{array}$ & $\begin{array}{l}0.0010 \\
0.000 \\
0.006\end{array}$ & & 䭚: & $\begin{array}{l}95 \\
: 00 \\
: 20\end{array}$ & $\begin{array}{r}3.13 \\
0.13 \\
0.03\end{array}$ & $\begin{array}{l}835 \\
: 825\end{array}$ & $\begin{array}{r}.03 \\
-.07 \\
.04\end{array}$ & 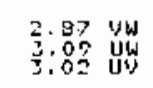 & $\begin{array}{r}-.0000 \\
.0001 \\
.0010\end{array}$ & $\begin{array}{l}7: 0 \\
8: 3 \\
3\end{array}$ & 品: & $\begin{array}{r}70: 1 \\
90: 0 \\
95: 3\end{array}$ & 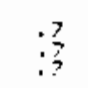 & $\begin{array}{r}.03 \\
-: 05 \\
-.04\end{array}$ & $\begin{array}{l}3.07 \\
3: 02 \\
3\end{array}$ \\
\hline 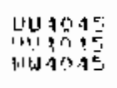 & 1 & $\begin{array}{r}r .00 \\
100 \\
1000\end{array}$ & $\begin{array}{l}0.000 \\
0.000 \\
0.000\end{array}$ & $\begin{array}{l}7.97 \\
1: 0 \frac{2}{3} \\
-82\end{array}$ & 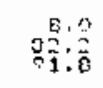 & $\begin{array}{l}7.10 \\
30 \\
: 30\end{array}$ & 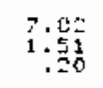 & $: 025$ & $\begin{array}{l}.04 \\
0.02 \\
: 04\end{array}$ & 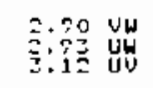 & $\begin{array}{r}0000 \dot{0} \\
000015\end{array}$ & 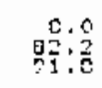 & 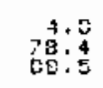 & $\begin{array}{l}12: 2 \\
85: 5 \\
05\end{array}$ & $?$ & $\begin{array}{l}.09 \\
.03 \\
.05\end{array}$ & 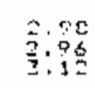 \\
\hline 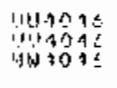 & $\begin{array}{l}1 \\
\vdots \\
\vdots\end{array}$ & $\begin{array}{r}950 \\
+200.00\end{array}$ & $\begin{array}{l}9.000 \\
3.000 \\
0.000\end{array}$ & & 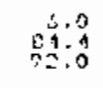 & 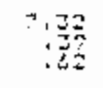 & $\begin{array}{l}3,01 \\
1: 20 \\
: 10\end{array}$ & 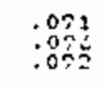 & $\begin{array}{l}.00 \\
: 05 \\
07\end{array}$ & 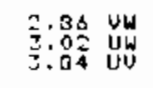 & $\begin{array}{r}.0009 \\
: 0010 \\
, 0009\end{array}$ & $\begin{array}{r}2.0 \\
0.0 \\
32: 0\end{array}$ & $\begin{array}{r}3: 1 \\
83: 0 \\
830\end{array}$ & $\begin{array}{r}9.9 \\
97: 1 \\
94.6\end{array}$ & 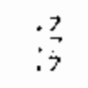 & 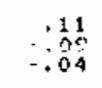 & $\begin{array}{l}3.03 \\
3.087 \\
3: 04\end{array}$ \\
\hline 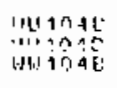 & $\stackrel{1}{3}$ & 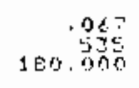 & $\begin{array}{l}8.000 \\
8.090 \\
8.08\end{array}$ & 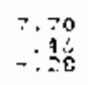 & $\begin{array}{l}4.0 \\
0.5 \\
0.1\end{array}$ & $\begin{array}{l}7.10 \\
-801 \\
-80\end{array}$ & $\begin{array}{c}3.09 \\
83 \\
185 \\
19\end{array}$ & $\begin{array}{r}007 \\
025 \\
025\end{array}$ & $\begin{array}{l}.02 \\
05 \\
05\end{array}$ & $\begin{array}{l}2.09 \\
3 \\
3: 11 \\
0\end{array}$ & $\begin{array}{r}.000 z \\
-00000\end{array}$ & 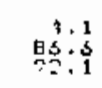 & อง: & $\begin{array}{l}8.0 \\
30: 1 \\
: 4: 9\end{array}$ & $: 3$ & $\begin{array}{l}.02 \\
.02 \\
.04\end{array}$ & $\begin{array}{l}3.14 \\
3 \\
2.12 \\
2.03\end{array}$ \\
\hline
\end{tabular}

Note: velocity values are possibly $2.5 \%$ low. 


\section{TABLE 3.3-3. (contd)}

FILE AYIS FOSITION

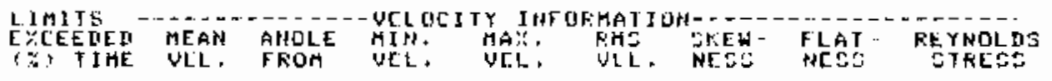

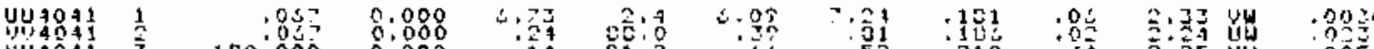

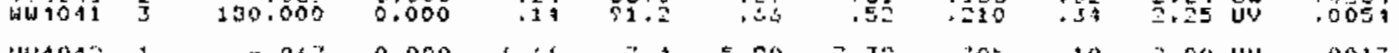

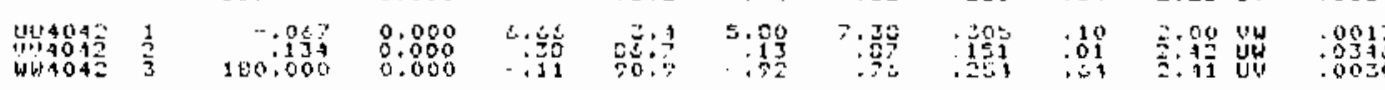

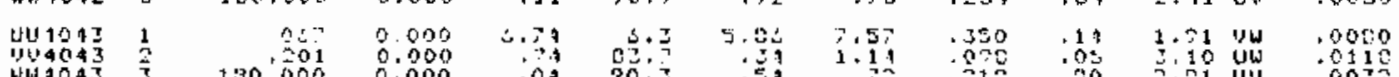

404049

409315

Wuthe

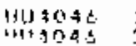

wh⿻ 4046

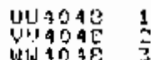

บ4 $40 \leqslant 0$.

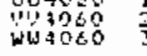

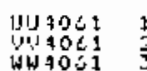

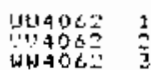

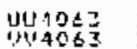

wato

1840

บ4 4055

4005

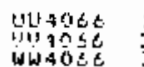

cond 0
$730.000 \quad 0.000$

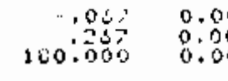

100.000

100.001
190

0.000
0.000
0.000

$130: 0000$

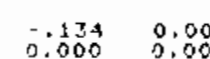

$\begin{array}{rll}0.000 & 0.000 \\ 8.000 & 0.800\end{array}$

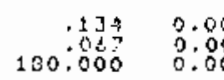

$\begin{array}{ccc}-137 & 0.000 \\ 0.13000 & 0.000\end{array}$

$100,000 \quad 0.000$

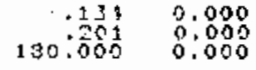

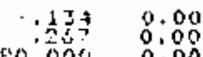$$
.134 \quad 0.009
$$

$130.000 \quad 0.000$

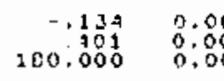

.134
100.000
0.0000
0.000
政

?

野

旅

6.06 01.0

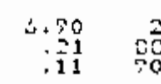

䊉

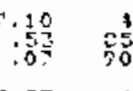

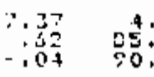

灌

7.70
70

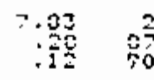

\section{i:}

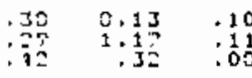

5
19

残 0.3

:

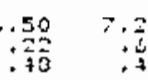

: 70

:

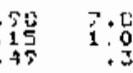

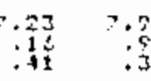

粮

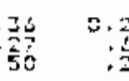

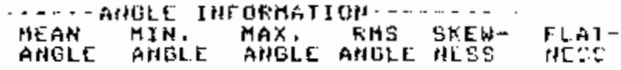

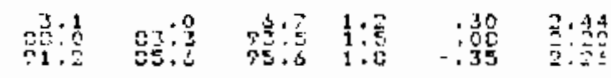

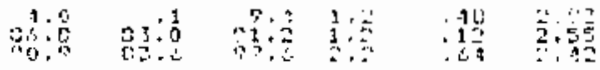

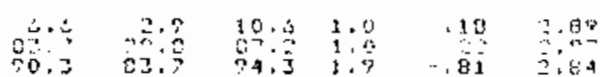

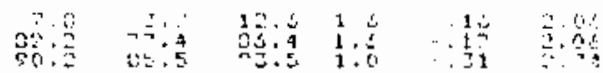

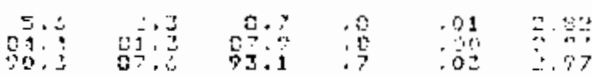

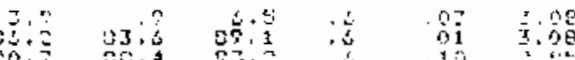

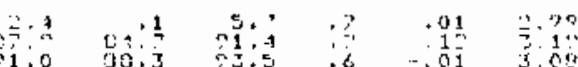

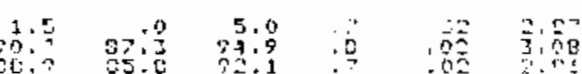

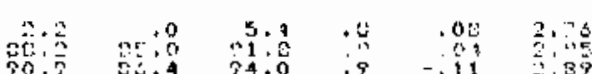

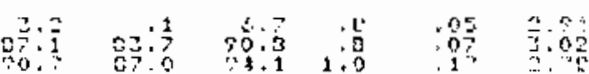

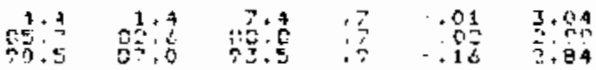

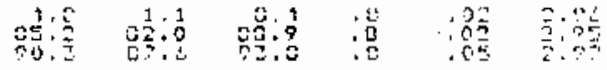

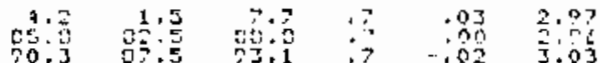

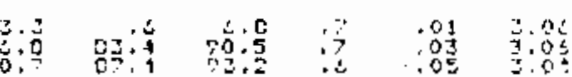

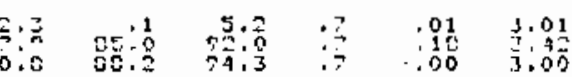




\section{TABLE 3.3-3. (contd)}

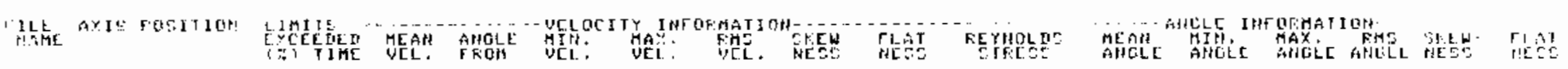

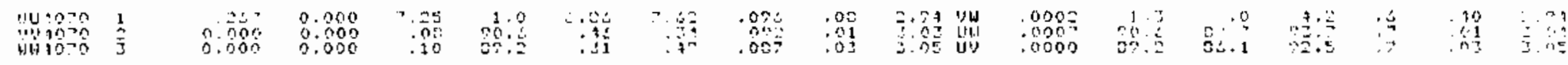

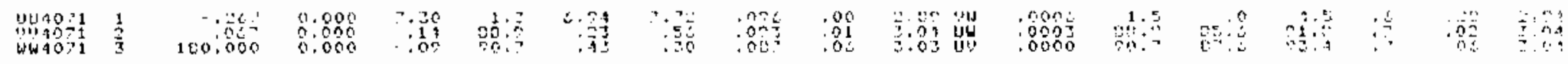

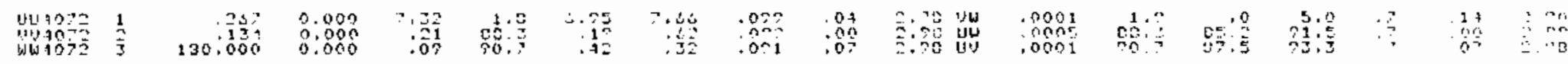

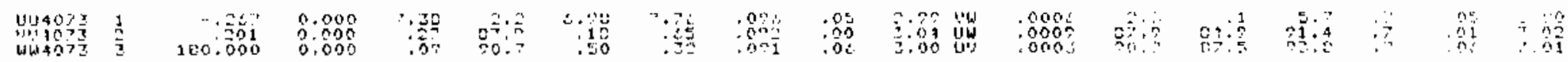

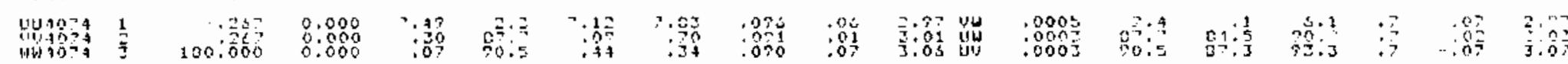

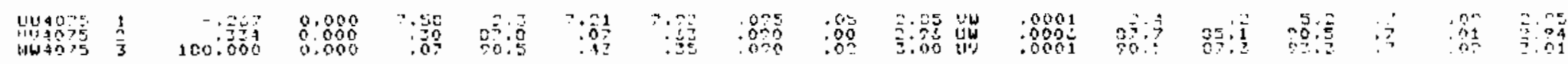

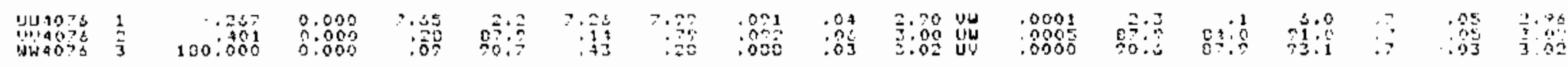

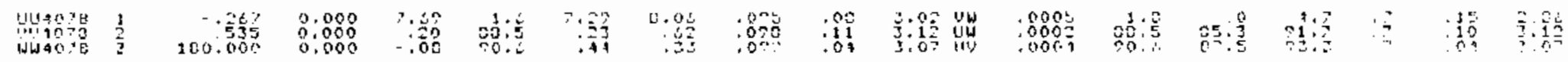




\section{APPENDIX A}

COORDINATE TRANSFORMATIONS 


\section{APPENDIX A}

\section{COORDINATE TRANSFORMATIONS}

The reduction algorithm for the TSI model 1294 probe calculates the velocity components along the sensor coordinate system. To find the values of the velocity components in the tunnel coordinate system, several intermediate transformations must be safe. Figure A.1 details the different coordinate systems that will be discussed here.

Consider the general derivation of the transformation tensor that relates the magnitudes of vector quantities $\left(u_{j}\right)$ in the "unprimed" Cartesian coordinate system to the magnitudes ( $u_{j}^{\prime \prime \prime}$ ) resolved in a "triple-primed" system. To transform from the unprimed system to the triple-primed system, three intermediate transformations must be made. The first transformation is a rotation of $a_{1}$ degrees about the $x_{1}$ axis. The second transformation is a rotation of $\alpha_{2}$ degrees about the new $\times \frac{1}{2}$ axis. The third transformation is a rotation of a3 degrees about the $\times 3$ axis.(a) These transformations can be stated mathematically as

(1) For $a_{1}$ rotation

$$
u_{k}^{\prime}=c_{k m} u_{m} \text {, where } c_{k m}=
$$

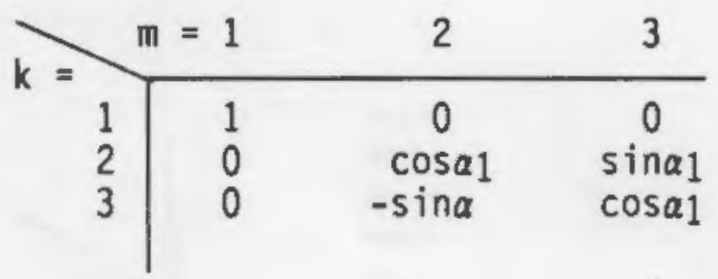

(2) For $a_{2}$ rotation

$$
u_{j}^{\prime \prime}=b_{j k} u_{k} \text {, where } b_{j k}=
$$

$j=$\begin{tabular}{lllr}
$k=1$ & 2 & 3 \\
\cline { 2 - 4 } 1 & $\cos \alpha_{2}$ & 0 & $-\sin \alpha_{2}$ \\
2 & 0 & 1 & 0 \\
3 & $\sin \alpha_{2}$ & 0 & $\cos \alpha_{2}$
\end{tabular}

(a) The sense of the angular rotations is defined as follows: looking from the positive to negative direction along the axis in question a positive angle requires the counterclockwise rotation of the other two axes. 

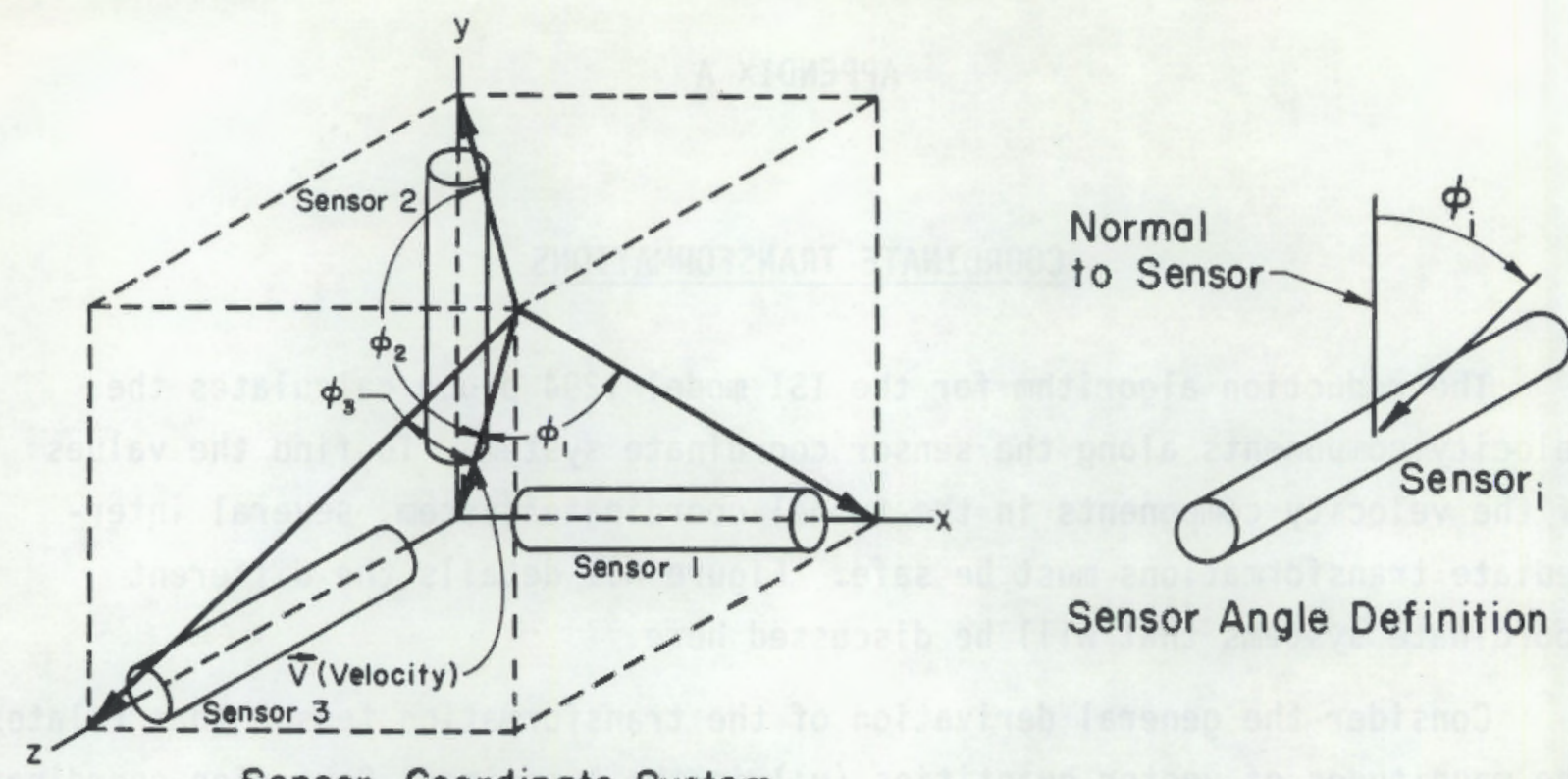

Sensor Coordinate System

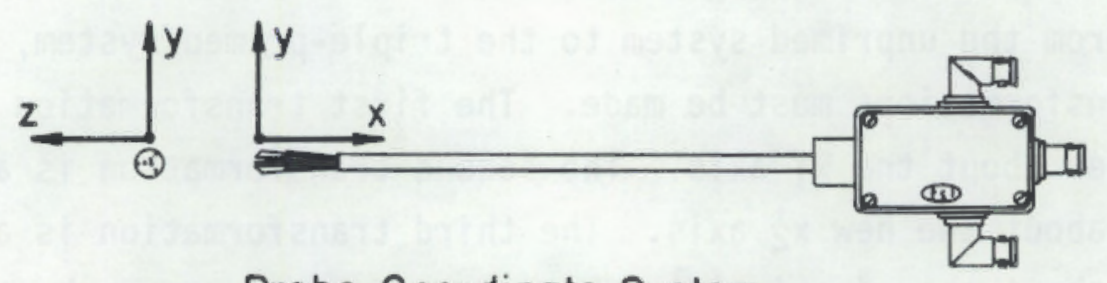

Probe Coordinate System
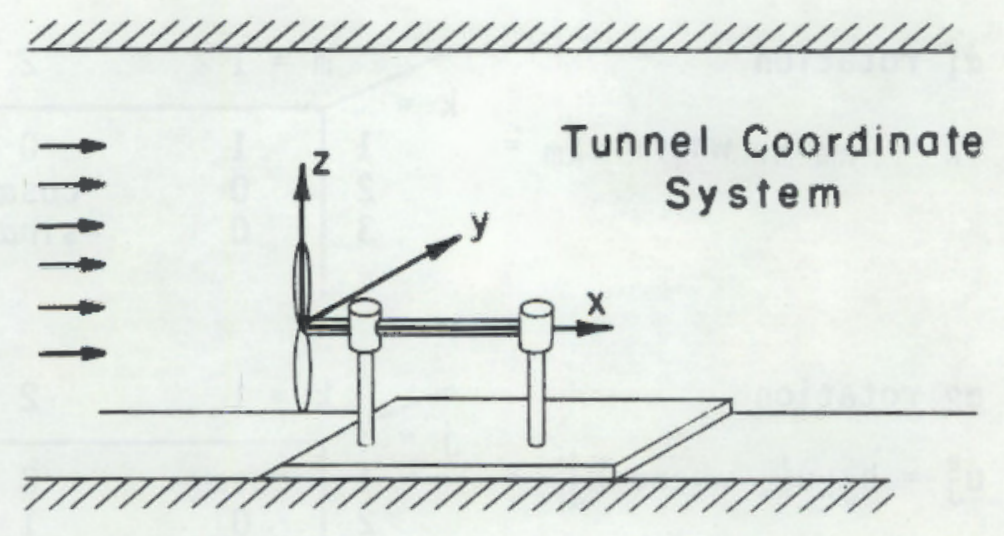

FIGURE A.1. Sensor, Probe, and Tunnel Coordinate Systems 
(3) For $a_{3}$ rotation

$$
u_{k}^{\prime \prime \prime}=a_{i j} u_{j}^{\prime \prime} \text {, where } a_{i j}=\begin{array}{l|ccc}
i= & & & \\
1 & \cos \alpha 3 & \sin \alpha 3 & 0 \\
2 & -\sin \alpha 3 & \cos \alpha 3 & 0 \\
3 & 0 & 0 & 1
\end{array}
$$

The components of the intermediate transformation tensors ( $c_{k m}, b_{j k}$, and $a_{j j}$ ) may be obtained from inspection. For example, $c_{k m}$ is the cosine of the angle between the $\mathrm{xth}$ primed and the mth unprimed coordinate axis, i.e., $\mathrm{ckm}=$ $\cos \left(x_{k}^{\prime}, x_{m}\right)$.

Grouping the three transformations into one completes the general derivation of the vector component relationships between the unprimed and the tripleprimed systems.

where $\quad A_{i \pi}=\left[\begin{array}{lll}\cos \alpha_{2} \cos \alpha_{3} & \begin{array}{l}\cos \alpha_{1} \sin \alpha_{3}+ \\ \sin \alpha_{1} \sin a_{2} \cos \alpha_{3}\end{array} & \begin{array}{l}\sin \alpha_{1} \sin \alpha_{3}- \\ \cos \alpha_{1} \sin \alpha_{2} \cos \alpha_{3}\end{array} \\ -\cos \alpha_{2} \sin a_{3} & \begin{array}{l}\cos \alpha_{1} \cos \alpha_{3}- \\ \sin \alpha_{1} \sin \alpha_{2} \sin \alpha_{3}\end{array} & \begin{array}{l}\sin \alpha_{1} \cos \alpha_{3}+ \\ \cos \alpha_{1} \sin \alpha_{2} \sin \alpha_{3}\end{array} \\ \sin \alpha_{2} & -\sin a_{1} \cos \alpha_{2} & \cos \alpha_{1} \cos \alpha_{2}\end{array}\right]$

It should be noted that the transpose of $A_{i m}=A T_{m}=A_{m i}$ can be used to transform vector components in the triple-primed system to those in the unprimed system, i.e., $u_{j}=A_{m i} u_{m}^{\prime \prime}$ '.

The geometric relationship between the sensor coordinates and the probe coordinates is always fixed, but the relationship between the probe coordinates and the wind-tunnel coordinate also needs to be formalized before an overall transformation from sensor coordinates to wind-tunnel coordinates can be stipulated. During physical placement of the probe within the wind tunnel, one starts with the probe coordinates aligned with the wind-tunnel coordinates. The probe and thus the probe coordinate system is first rotated $\gamma_{3}$ degrees about the $x^{\frac{\hbar}{* \star}}$ axis, then $\gamma_{2}$ degrees about the new $\times 2^{\star \star}$ axis, and then $\gamma_{1}$ 
degrees about the new $x=$ axis. After these rotations of the probe by its supporting mechanism are completed, the probe is in position to take data.(a)

To find the coordinate transformations that are necessary to convert vector components in the sensor system (unprimed) coordinates to the probe system (triple-primed) coordinates, consider the reverse transform, i.e., probe system to sensors. It is seen in Figure A.1 that a rotation sequence of $a_{1}=0, a_{2}=35.26$, and $\alpha_{3}=-45.0$ will achieve the desired orientation. This transform can be written as

$$
u_{i}=A_{i j} u_{j}^{\prime \prime \prime}
$$

where $A_{i j}$ is calculated from the general derivation given previously. We are more interested in the reverse transform, $i . e$. , sensor to probe. This is found by taking the transpose of tensor $A_{i j}$ above, $i . e$. ,

$$
u_{i}^{\prime \prime \prime}=A_{i j}^{\top} u_{j}=A_{j i} u_{j} \text {. }
$$

Inserting $a_{1}=0, a_{2}=35.26$, and $a_{3}=-45.0$ into the equations for the components of $\mathrm{A}_{j i}$, one finds that the transformation tensor for conversion of velocity components in the sensor system to velocity components in the probe system is

$$
A_{j i}=\left[\begin{array}{rrl}
1 / \sqrt{3} & 1 / \sqrt{3} & 1 / \sqrt{3} \\
-1 / \sqrt{2} & 1 / \sqrt{2} & 0 \\
-1 / \sqrt{6} & -1 / \sqrt{6} & 2 / \sqrt{6}
\end{array}\right]
$$

(a) The reason for aligning the probe away from the tunnel coordinates is that the probe's $x_{1}$ axis should be in approximate alignment with the expected mean velocity vector. This will increase the accuracy of the measurement. For low-to-moderate turbulence levels it insures that the velocity vector never leaves the sensor coordinate system octant in which measurements are possible. 
To convert the velocity components resolved in the probe coordinate system to those of the wind-tunnel system one must reverse the rotational order that was used during the physical placement of the probe.

$$
\begin{aligned}
& u_{k}^{*}=c_{k m} u_{m}^{\prime \prime \prime} \text { then } u_{j}^{* *}=b_{j k} u_{k}^{*} \text { then } \\
& u_{i}^{* \star *}=a_{i j} u_{j}^{* *} \quad \Rightarrow \quad u_{i}^{* \star}=B_{i m_{m}} u^{\prime \prime \prime}
\end{aligned}
$$

where the angles $a_{1}, a_{2}, a_{3}$ that make up the general transformation tensor are now defined as $-\gamma_{1},-\gamma_{2}$, and $-\gamma_{3}$, respectively.

Combining the two transformation tensors derived above, one for sensor to probe conversion and the other for probe to tunnel conversion, into one overall transformation tensor for sensor to tunnel system conversion yields (note that the indices have been changed for convenience)

$$
\begin{aligned}
& u_{j}^{\prime \prime \prime}=A_{j i} u_{i} \text { and } u_{k}^{k \star k}=B_{k j} u_{j}^{\prime \prime \prime} \\
& u_{k}^{k \star k}=B_{k j} A_{j i} u_{i}=C_{k i} u_{i}
\end{aligned}
$$

where

$$
\begin{aligned}
& u_{k}^{* *} \equiv \text { velocity components in the tunnel coordinate system } \\
& u_{i} \equiv \text { velocity components in the sensor coordinate system } \\
& B_{k j} \equiv \text { general transformation tensor with } a_{1}=-\gamma_{1}, \alpha_{2}=-\gamma_{2}, a_{3}=-\gamma_{3} \\
& A_{j i} \equiv \text { transpose of the general transformation tensor with } \alpha_{1}=0, \\
& \alpha_{2}=35.26, \alpha_{3}=-45 .
\end{aligned}
$$

Since the elements of $C_{k i}$ are the cosine of the angle between the $i$ th sensor coordinate and the kth tunnel coordinate, the yaw angles in calibration mode are easily calculated as

$$
\phi_{i}=90.0-\arccos C_{1 i}=\arcsin C_{1 i} .
$$

To convert from the rectangular tunnel coordinates to an axisymmetric tunnel coordinate system it is only necessary to rotate the rectangular system 
about the $x_{1}$ axis so that the measurement location is contained within the $x_{1}-x_{2}$ plane. This angle of rotation is given by the following conditional statements:

1. if $\times_{2}=0$ and $\times 3=0$ then $\beta=0$

2. if $\times_{2}=0$ and $x_{3}>0$ then $\beta=90.0$

3. if $\times_{2}=0$ and $x_{3}<0$ then $\beta=-90.0$

4. if $x_{2}<0 \quad$ then $\beta=\arctan \left(x_{3} / x_{2}\right)+180.0$

5. if $x_{2}>0 \quad$ then $\beta=\arctan \left(x_{3} / \times_{2}\right)$.

The transformation can be summarized as

$$
u_{m}^{0}=d_{m k} u_{k}^{* \star *}=d_{m k} c_{k i} u_{i}=0_{m i} u_{i}
$$

where

$u k \equiv$ velocity components in the axisymmetric tunnel system, and $d_{m k} \equiv$ general transformation tensor with $\alpha_{1}=\beta_{1} \alpha_{2}=0, \alpha_{3}=0$. 
APPENDIX B

COMPUTER PROGRAMS 


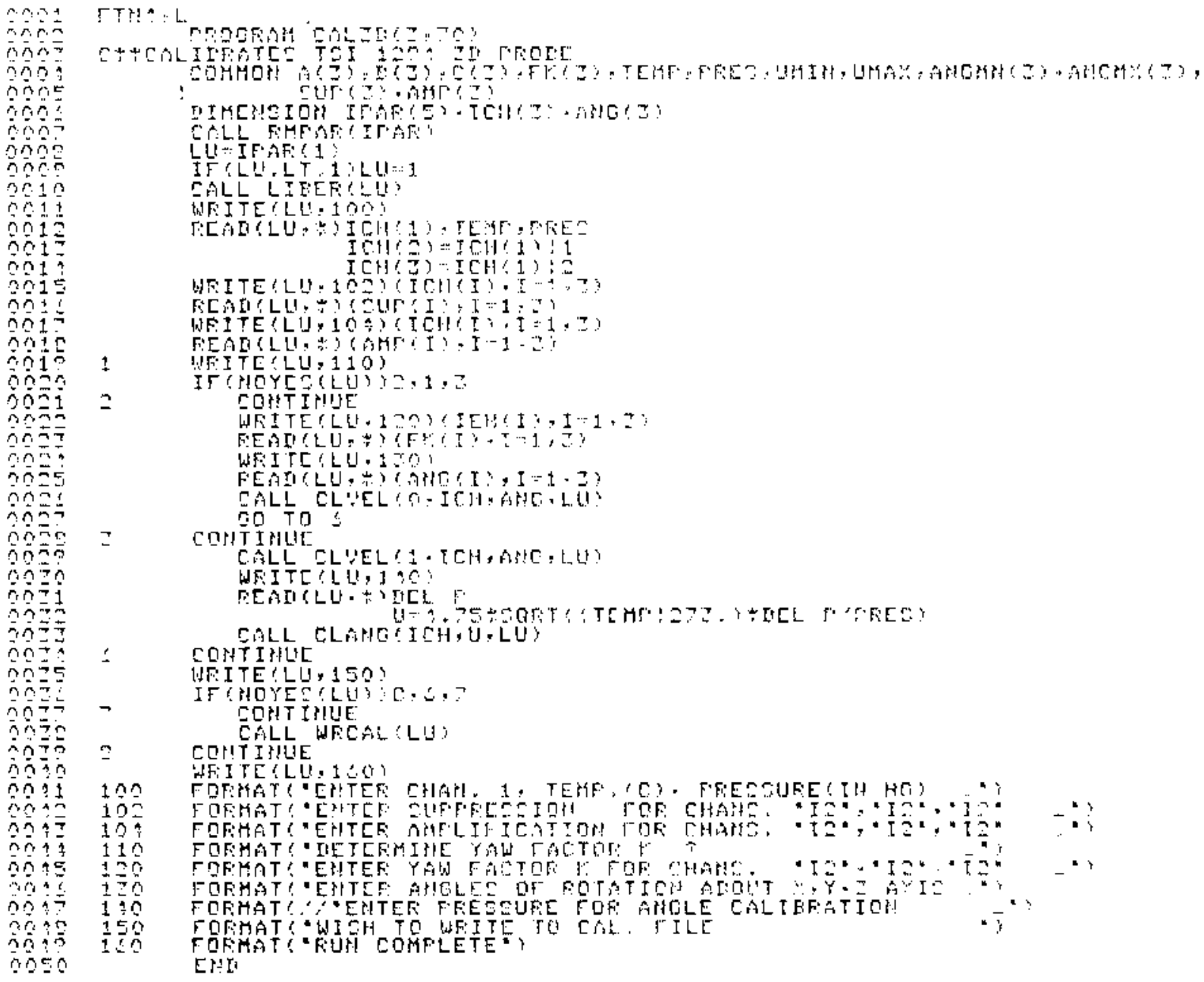

\section{B. 1}




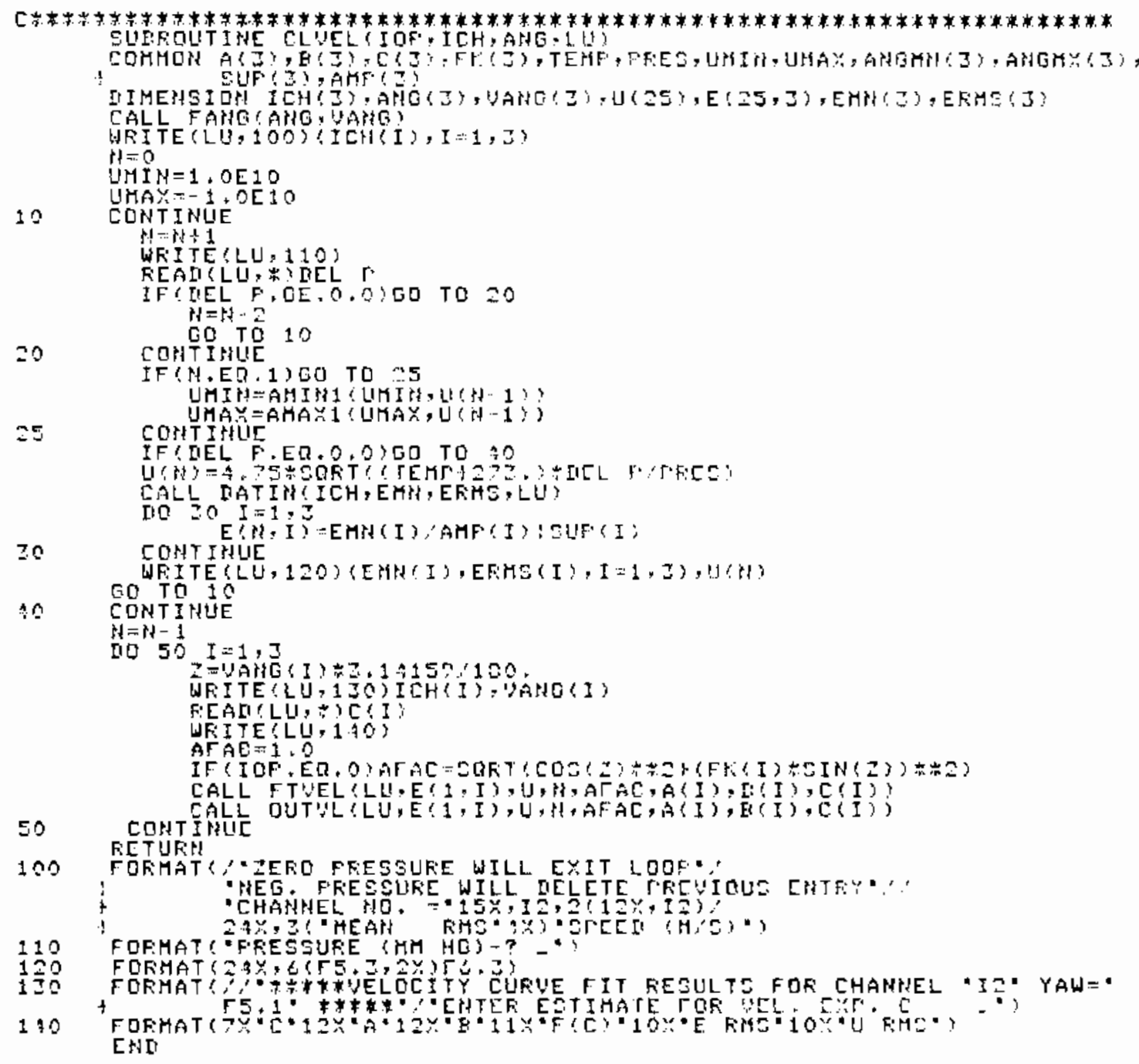




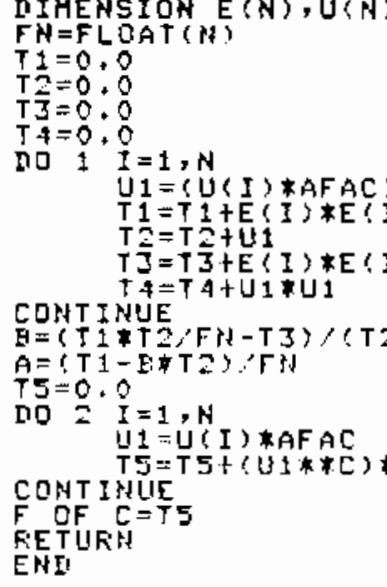




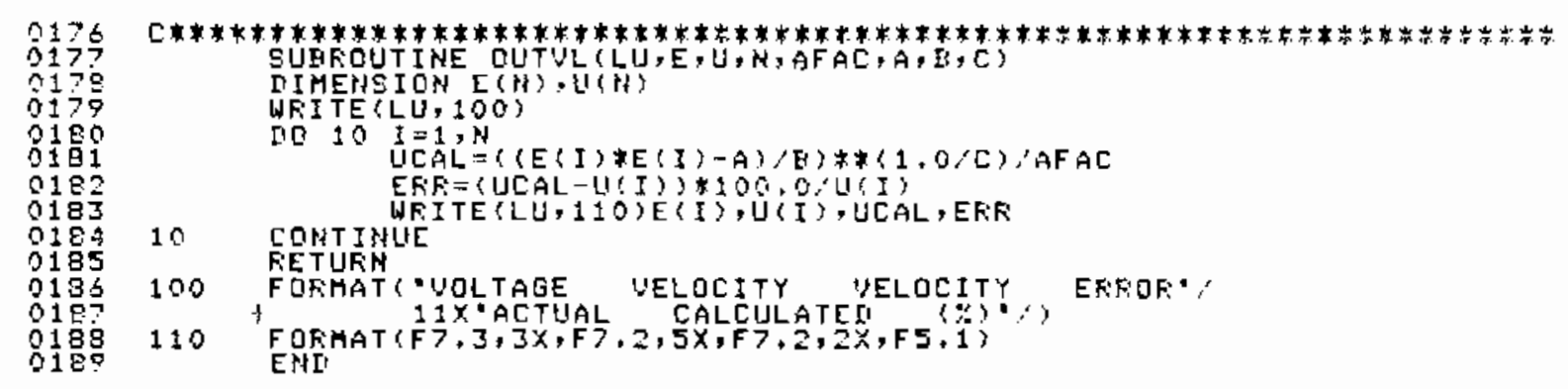




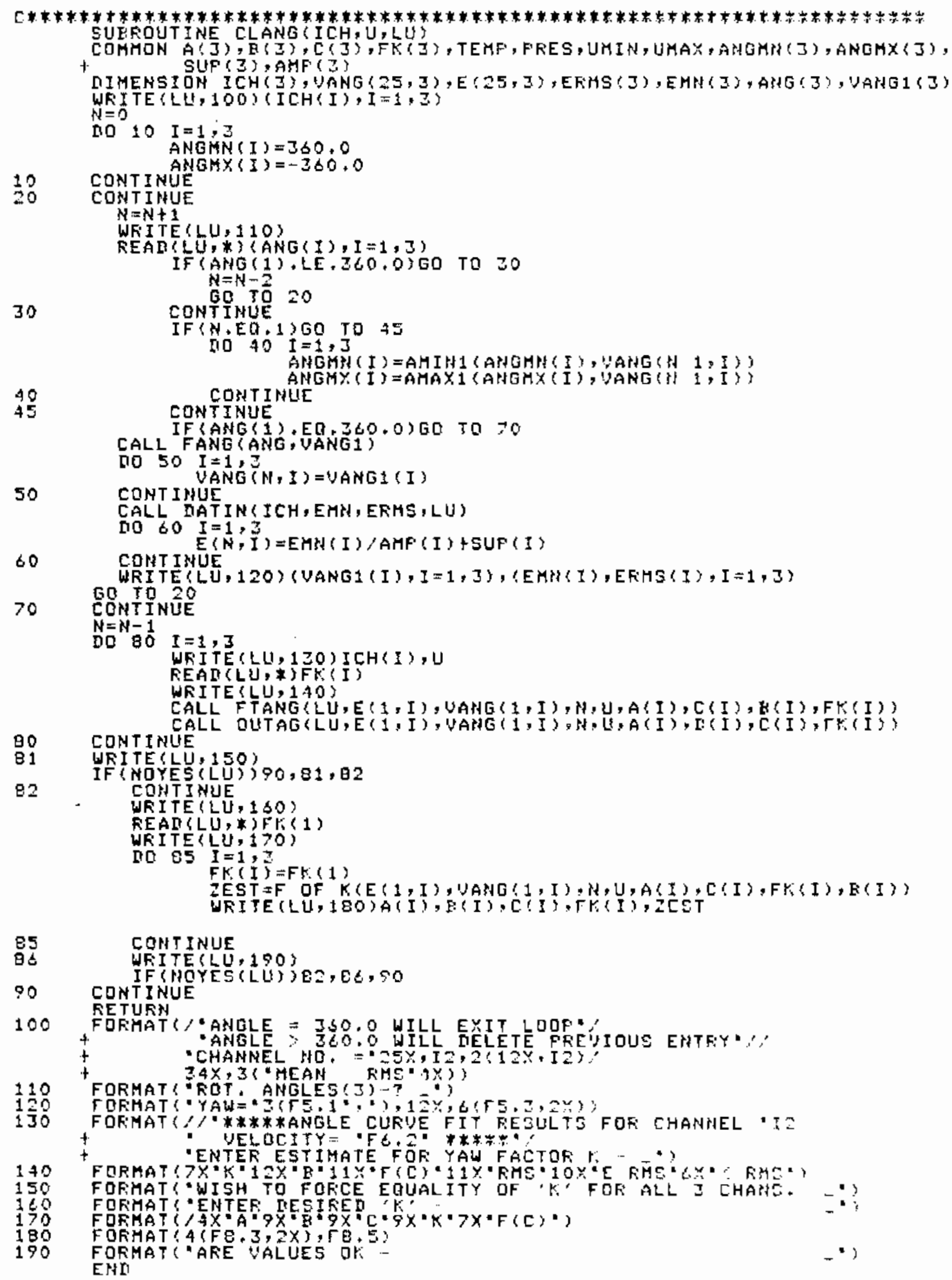




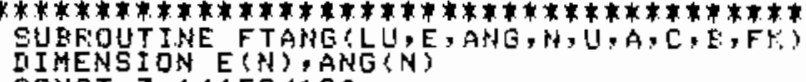




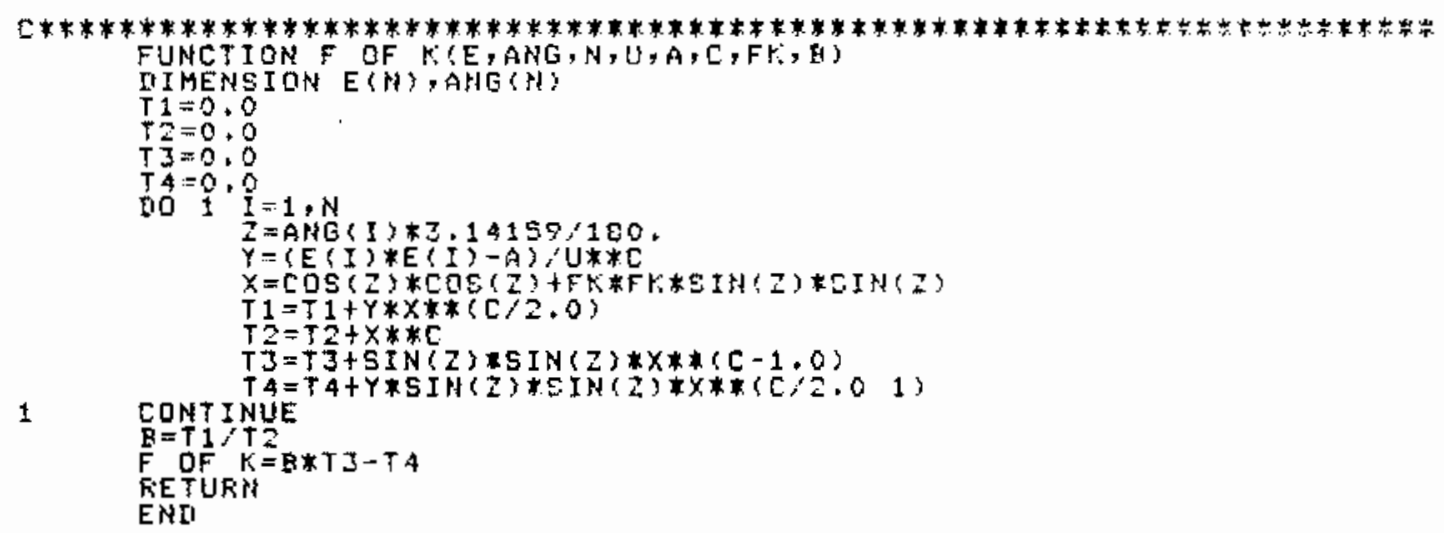




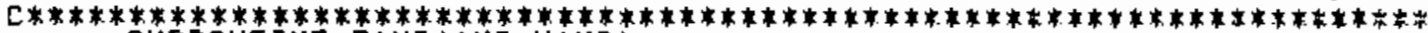
SURROUTINE FANG (ANG, UAMG)

DIMENEION ANG $(3)$, VANG $(3), A(3,3), E(Z, Z)$

CONST $=3,34159 / 180.0$

$X=0.0 * C O N S T$
$Y=35,25 * C O N S T$

$Z=-45,0 * C O N S T$

CALL TRXYZ $(A, X, Y, Z$

$X=A N G(1) * C D N S T$

$Z=A N G(3) * C D N E T$

CALL TRXYZ(B,X,Y,Z)

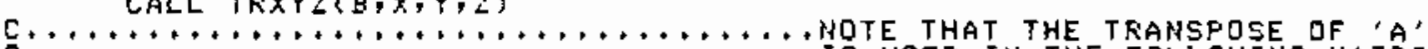

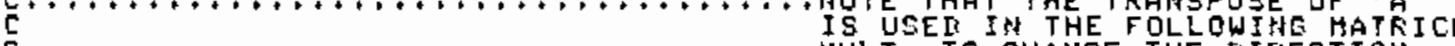
HULT. TO CHAMGE THE IIIRECTIOH OF, THE TRAHEFOFHATIOH THAT FORMED

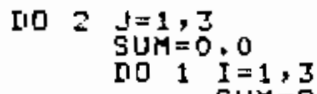
SUEROUTINE TRXYZ(A,X,Y,Z)

DIHENISION $A(3,3)$

$A(1,1)=\operatorname{CDS}(Y) * \operatorname{COS}(Z)$

$A(1,2)=\operatorname{COS}(X) * S I N(Z)+S I A(X) * S I N(Y) * \operatorname{COS}(Z)$

$A(1,3)=S I N(X) * S T N(Z)-\operatorname{COS}(X) * \operatorname{SIN}(Y) * \operatorname{COS}(Z)$

$A(2,1)=-\operatorname{Cos}(Y) * \operatorname{SIN}(Z)$

$A(Z, Z)=-5 I N(X) * \operatorname{IN}(Y) * \operatorname{SIN}(Z)+\operatorname{Cos}(X) * \cos (Z)$

$A(Z, 3)=\operatorname{SIN}(X) * \operatorname{Cos}(Z)+\operatorname{COS}(X) * \operatorname{SIN}\{Y\} * \operatorname{SI}+\{(Z)$

$A(3,1)=\operatorname{SIN}(Y)$

$A(3, Z)=-S I N(X) * \operatorname{COS}(Y)$

$A(3,3)=\cos (X)+\cos (Y)$

SETUFN

END 


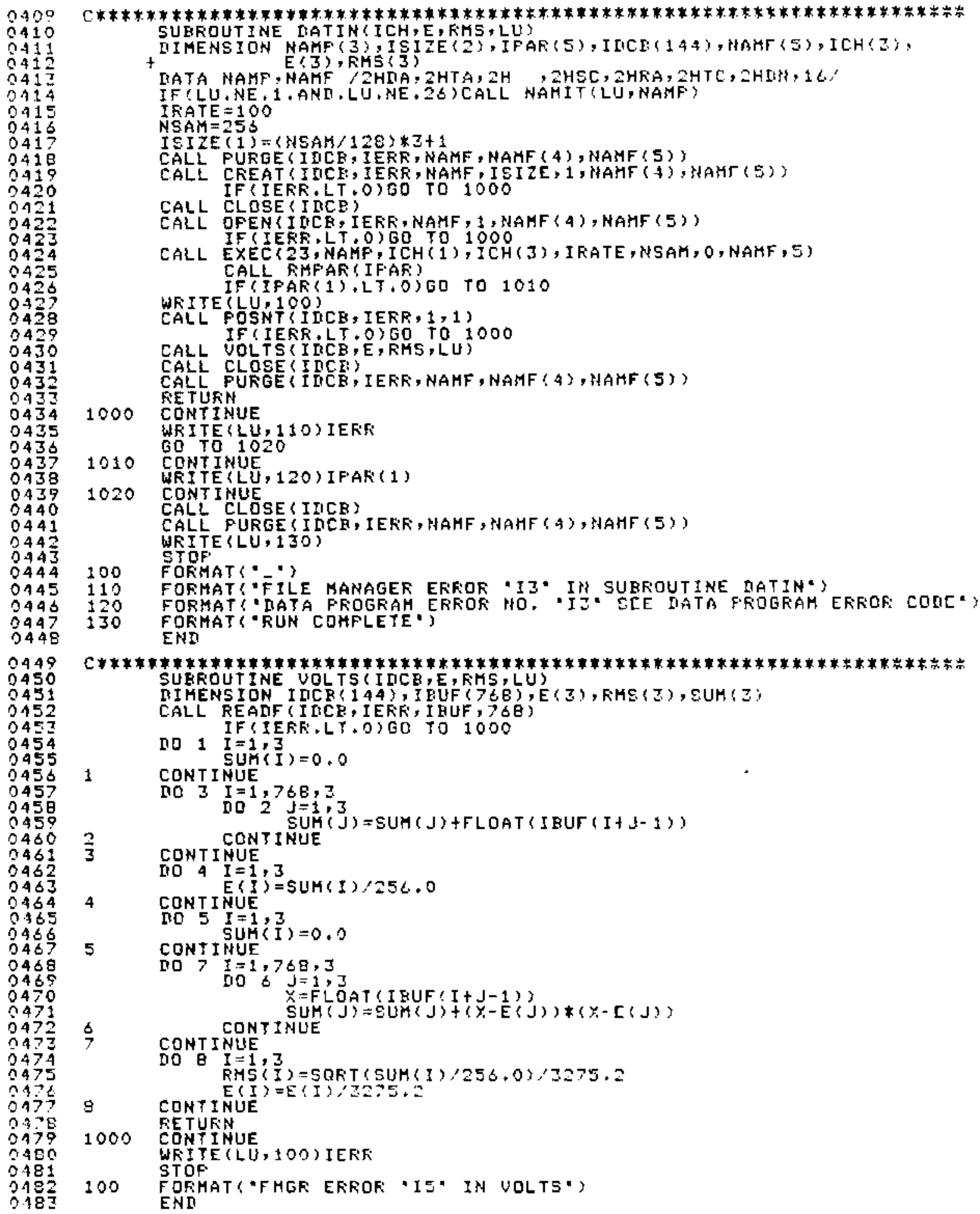




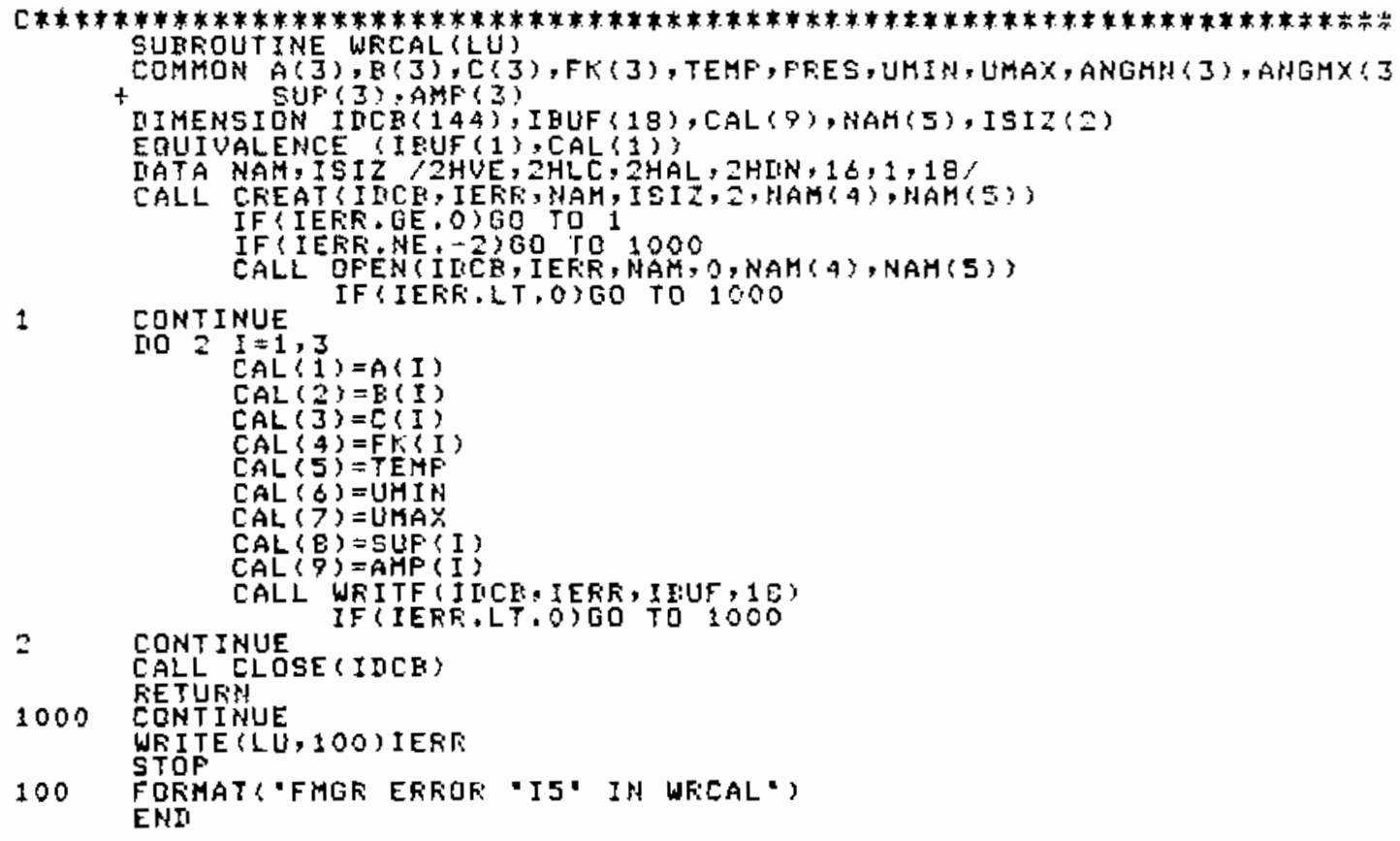




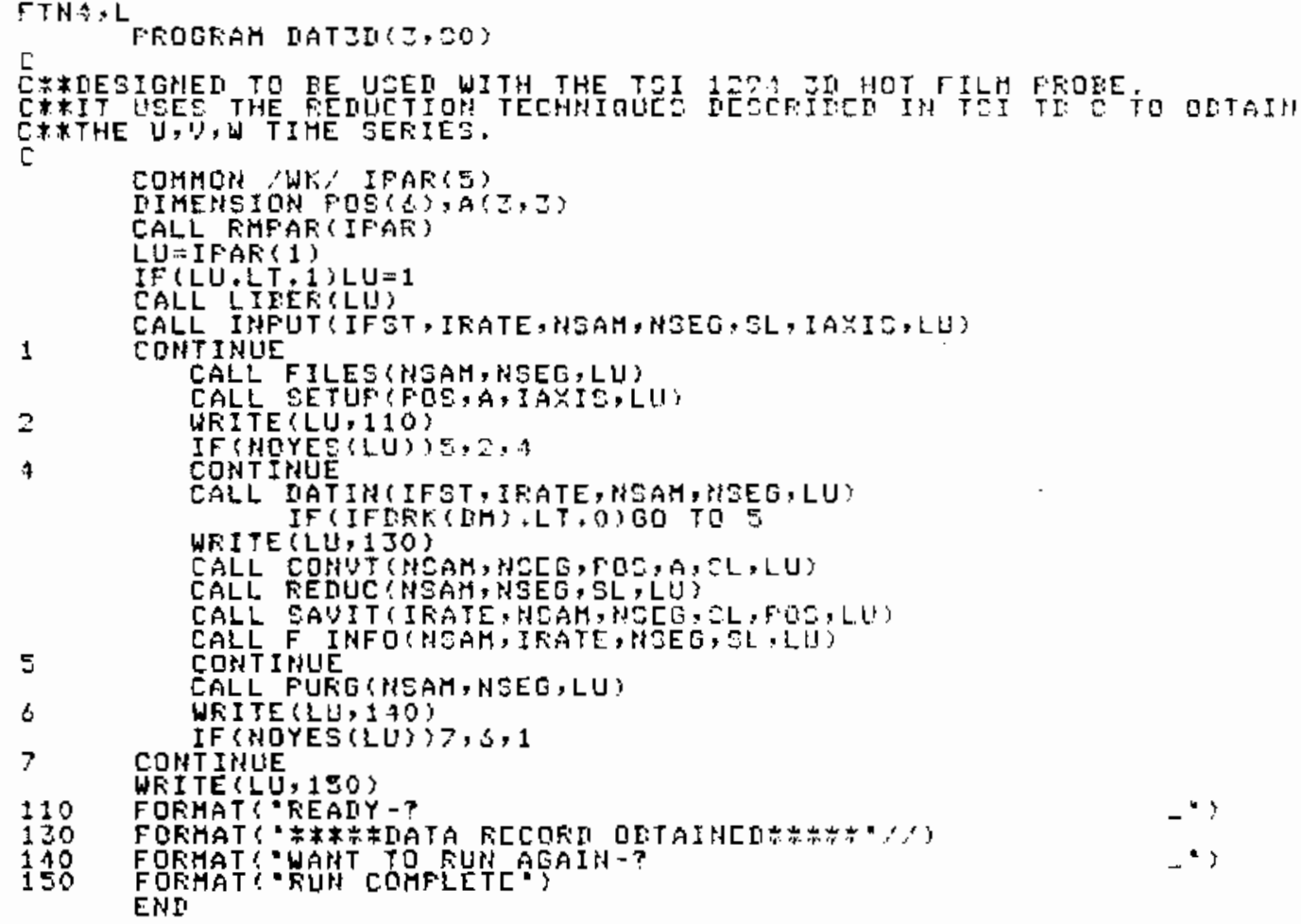




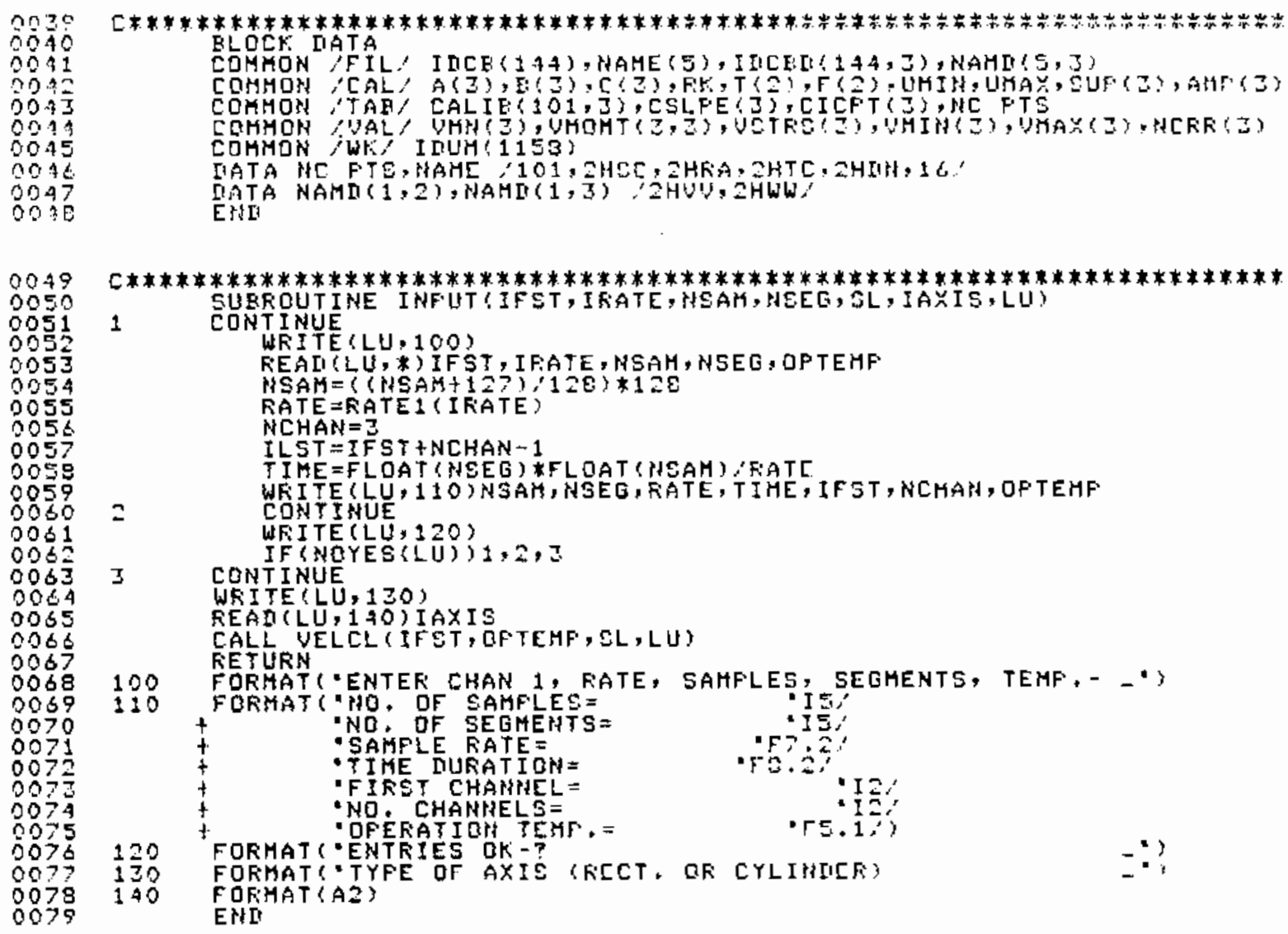




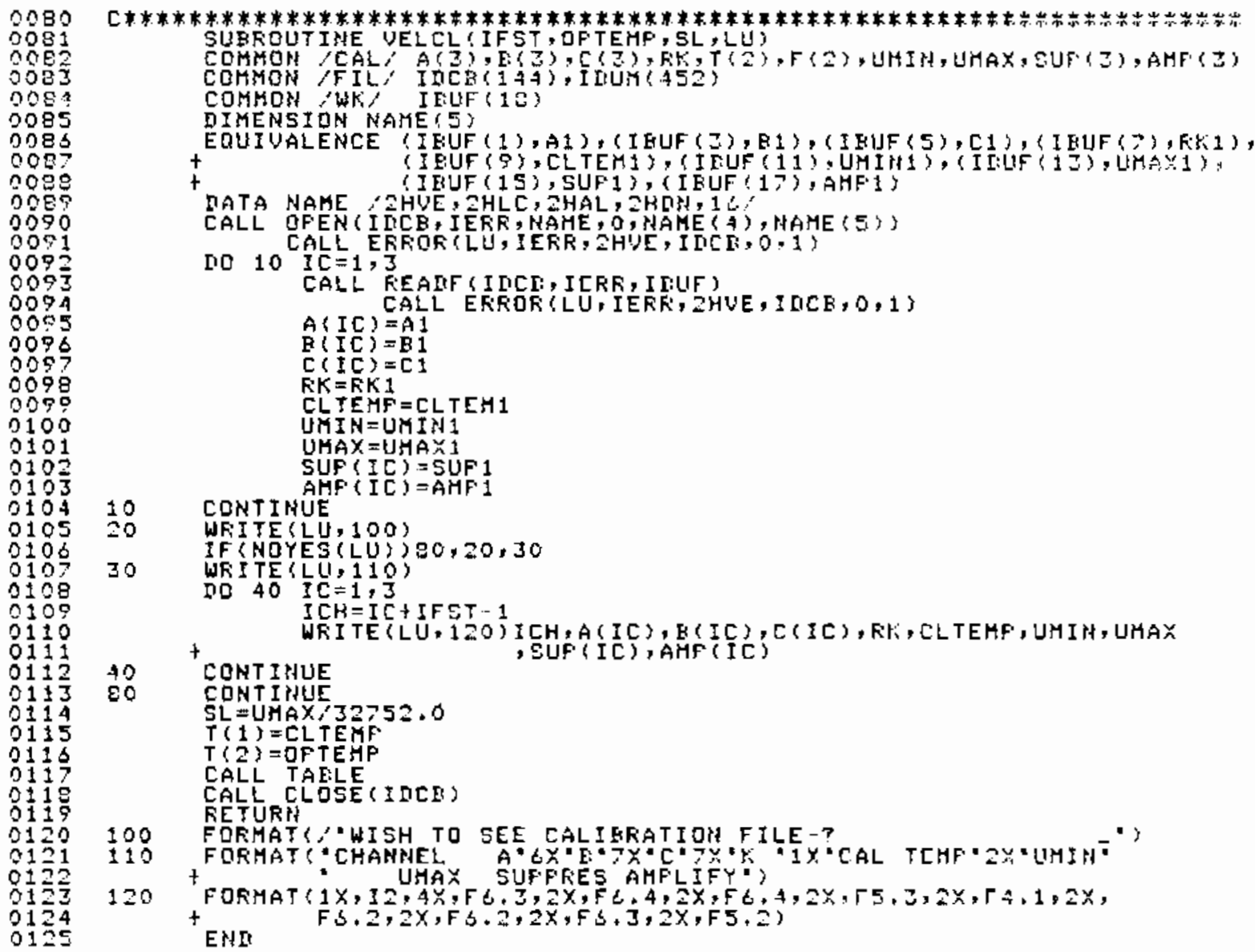




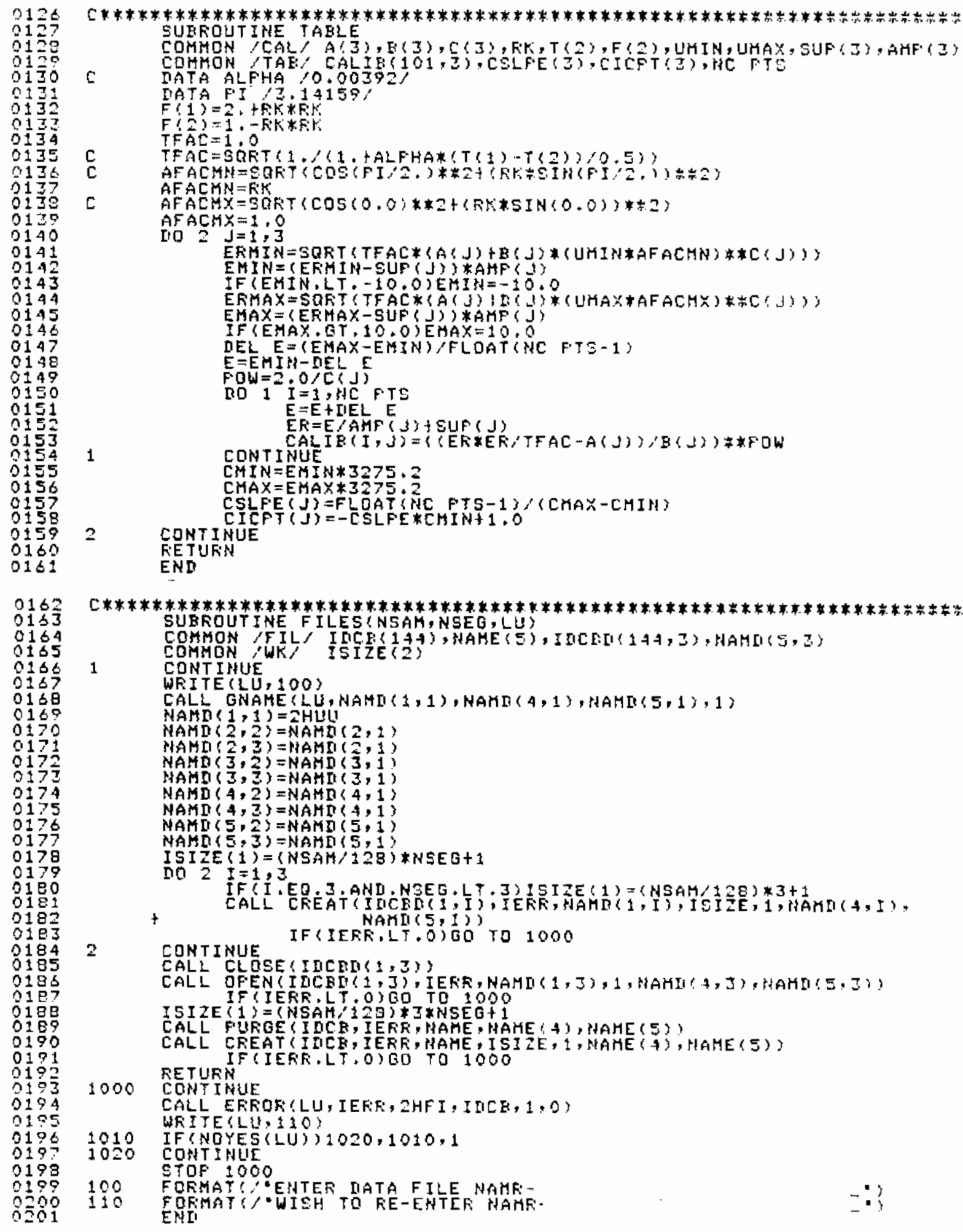




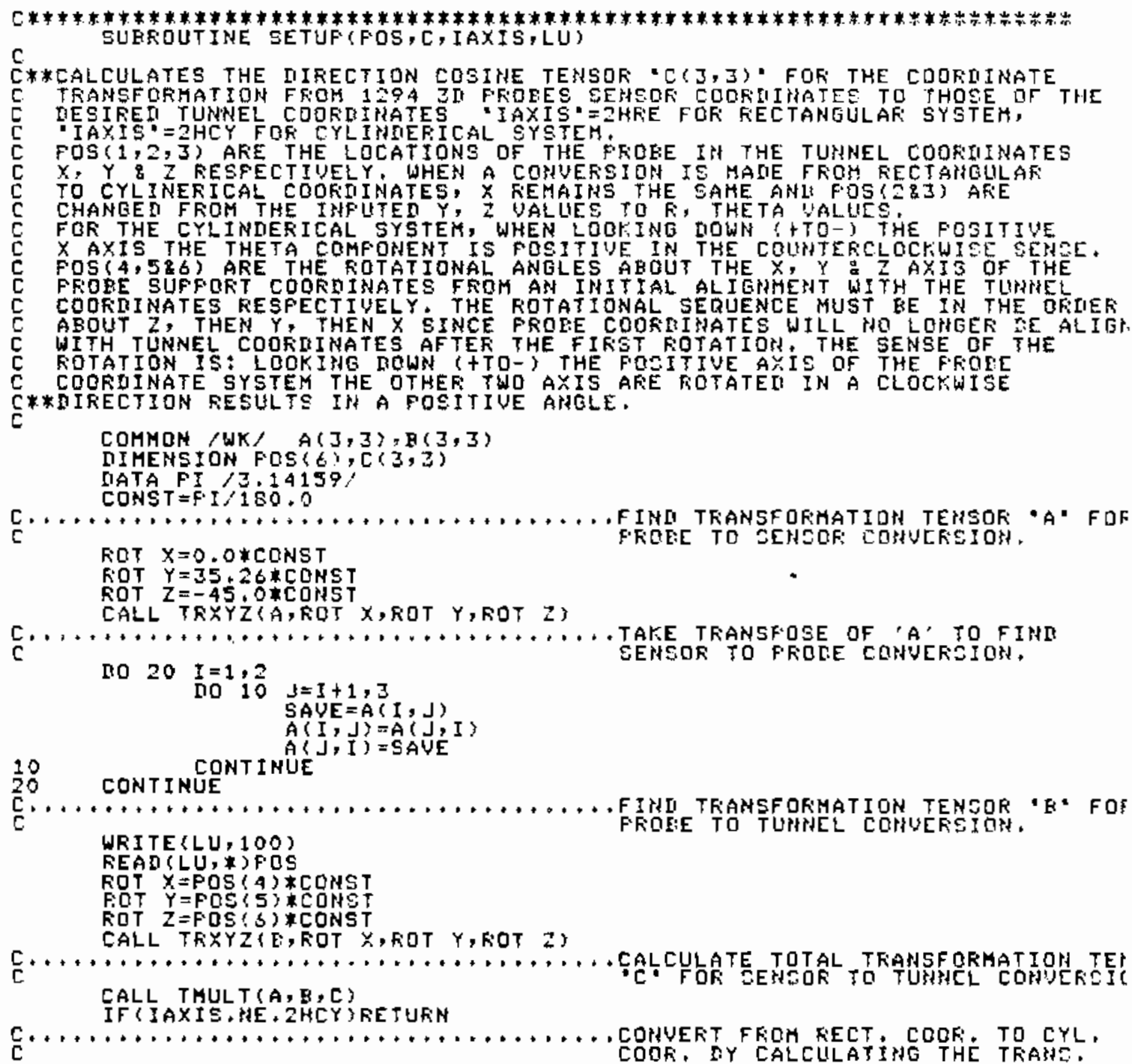




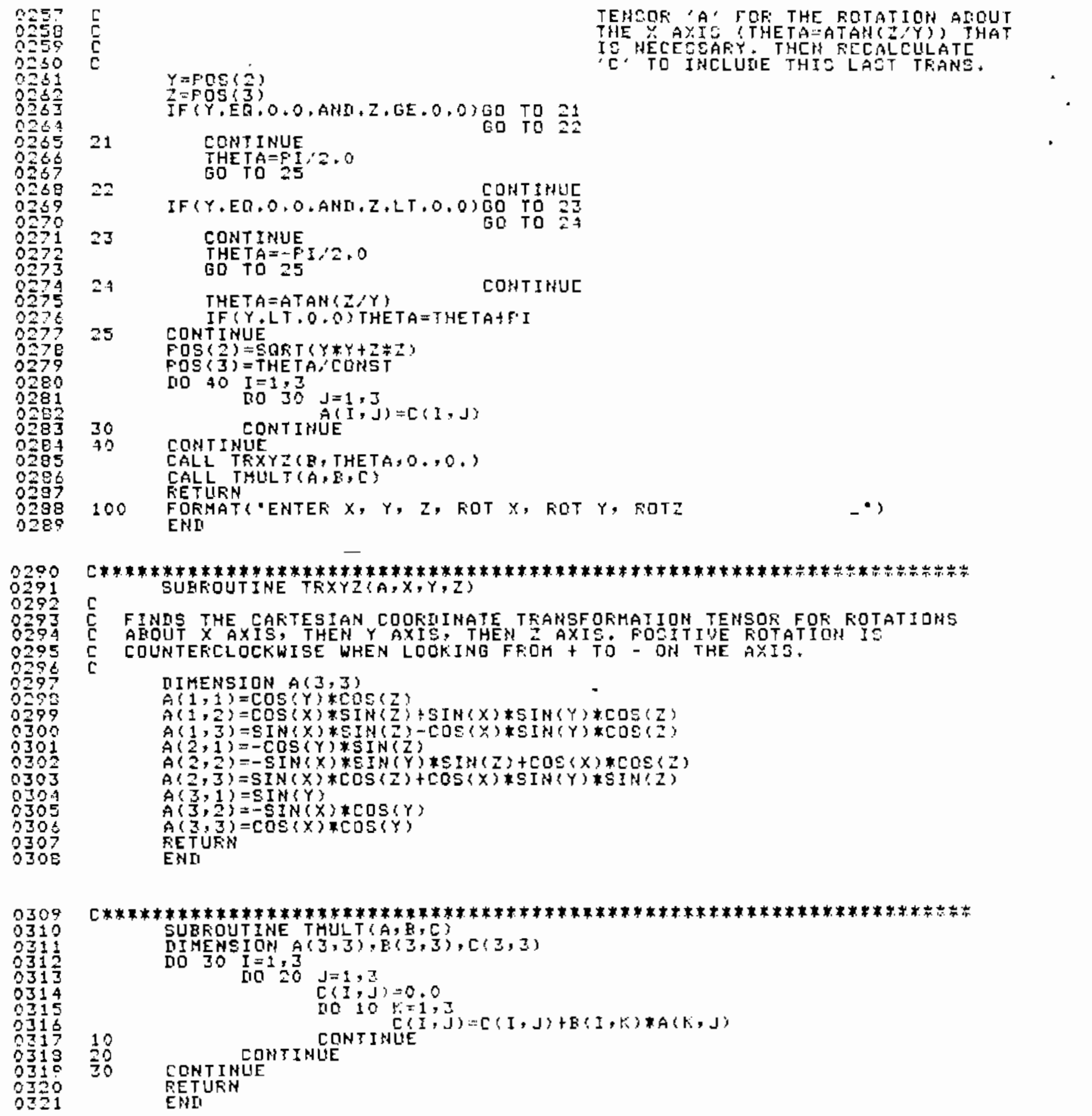




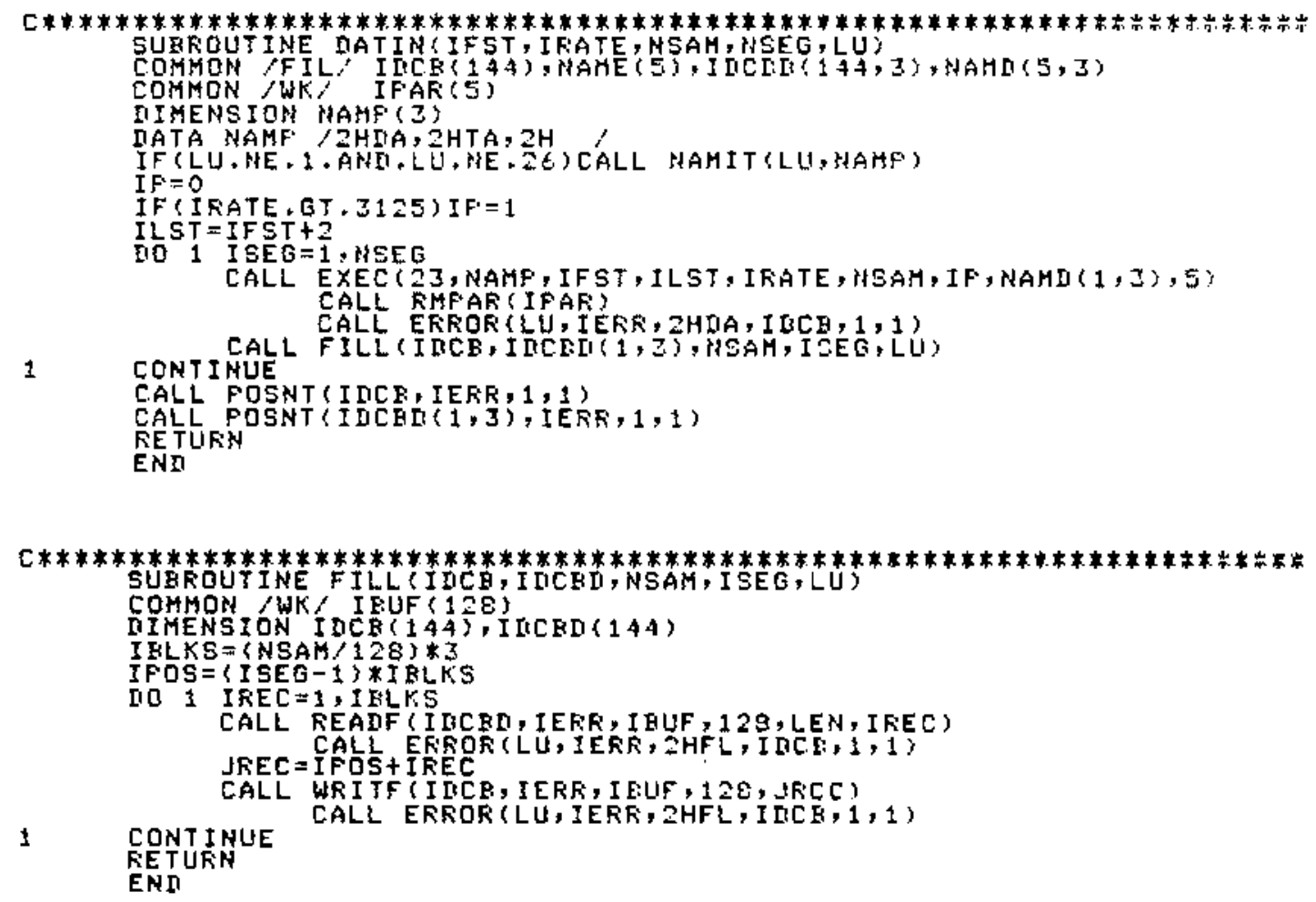




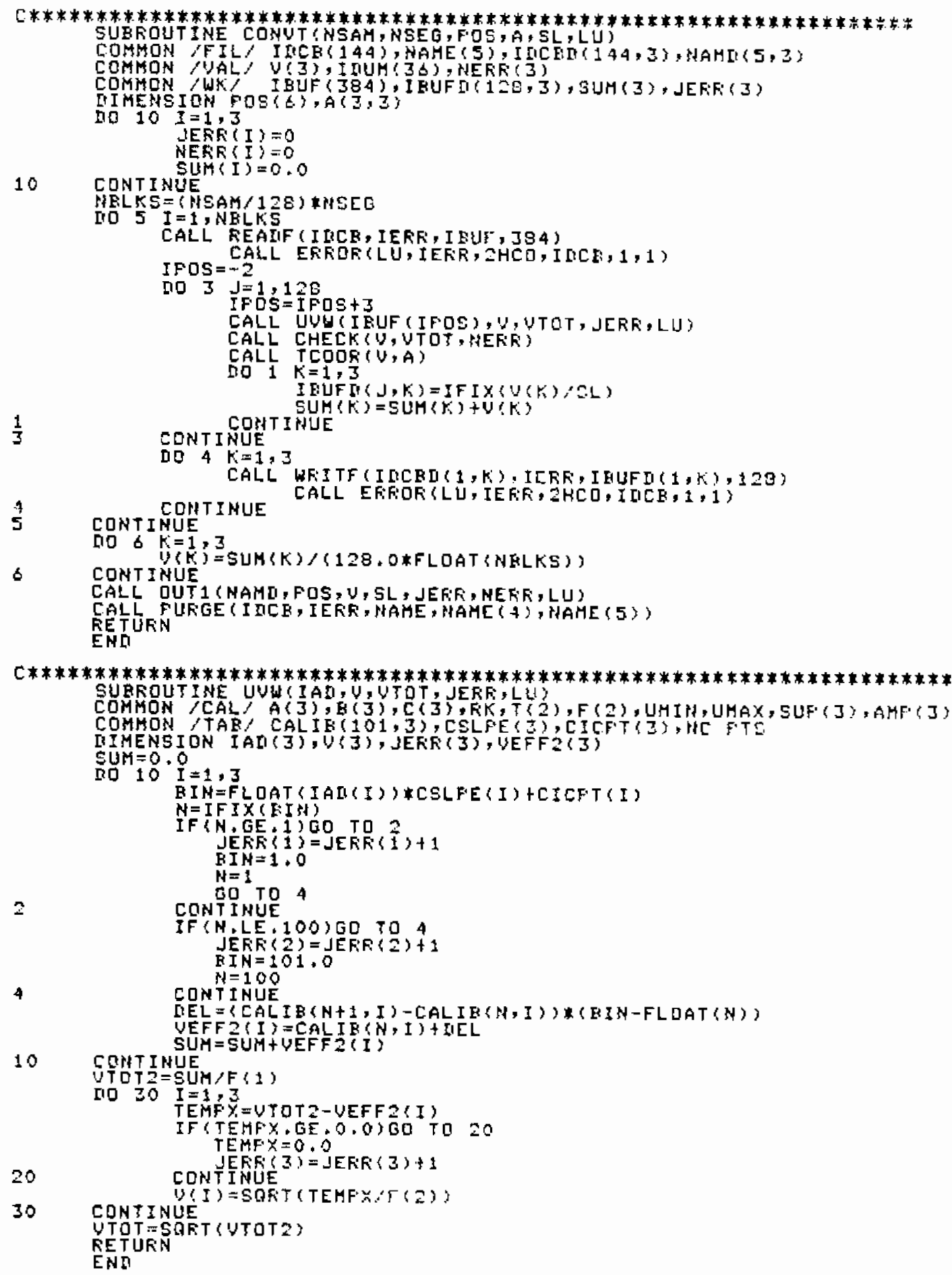




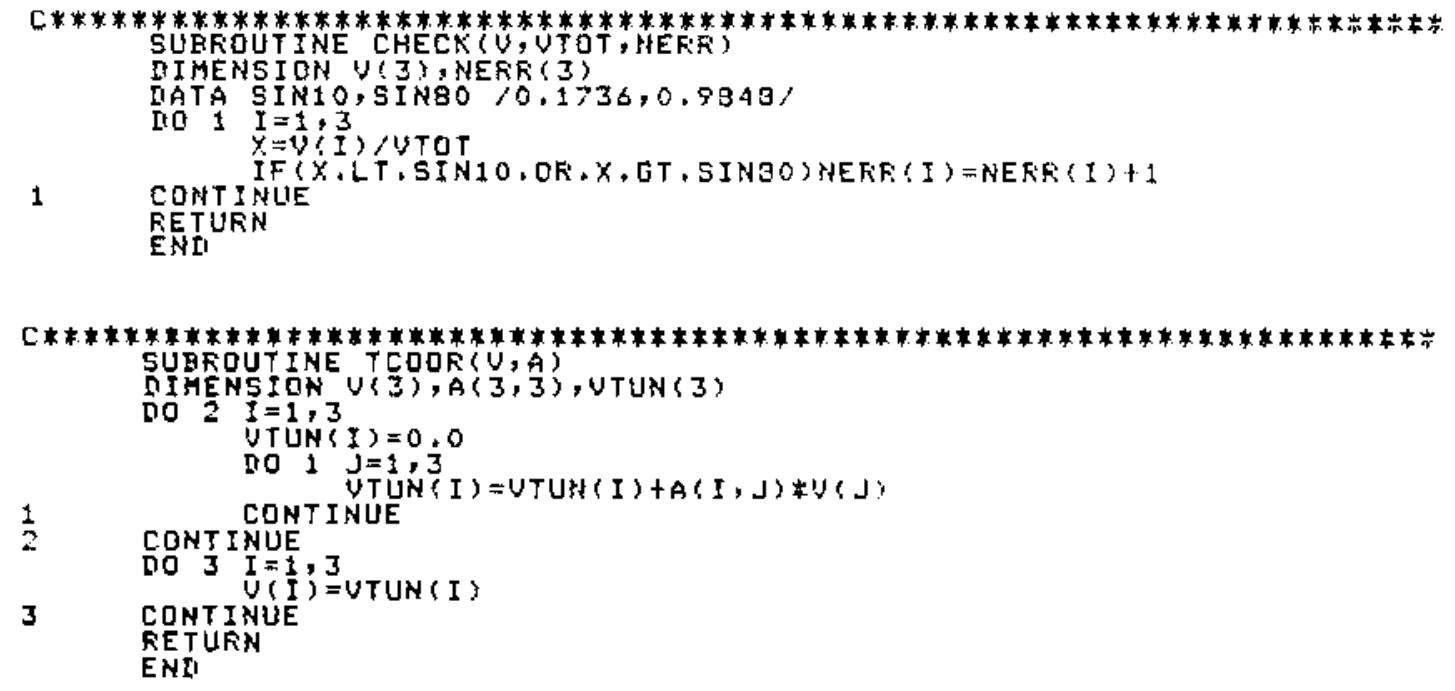


0490

0491

0493

0.494

0495

0496

0497

0498

049

0500

0502

0503

0504

0506

0507

0508

0510

051

051

051

0516

051 ?

$051 \mathrm{~B}$

0

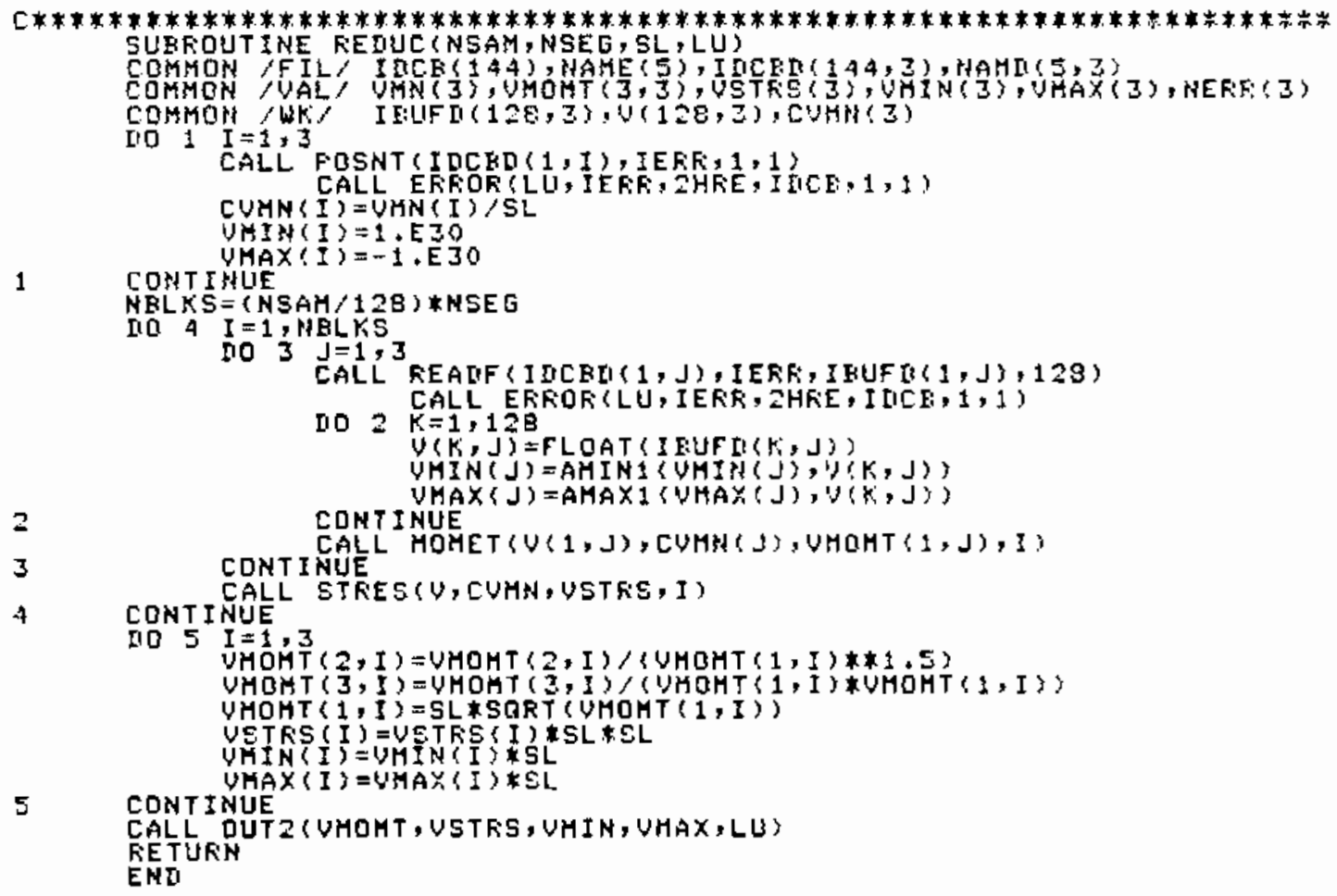

5

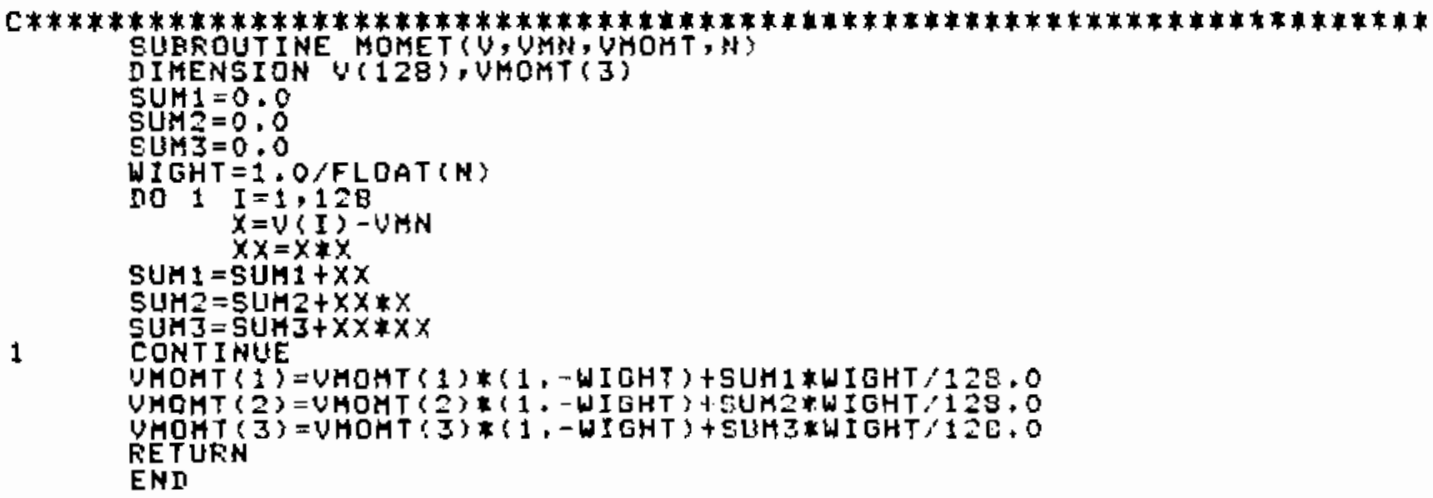




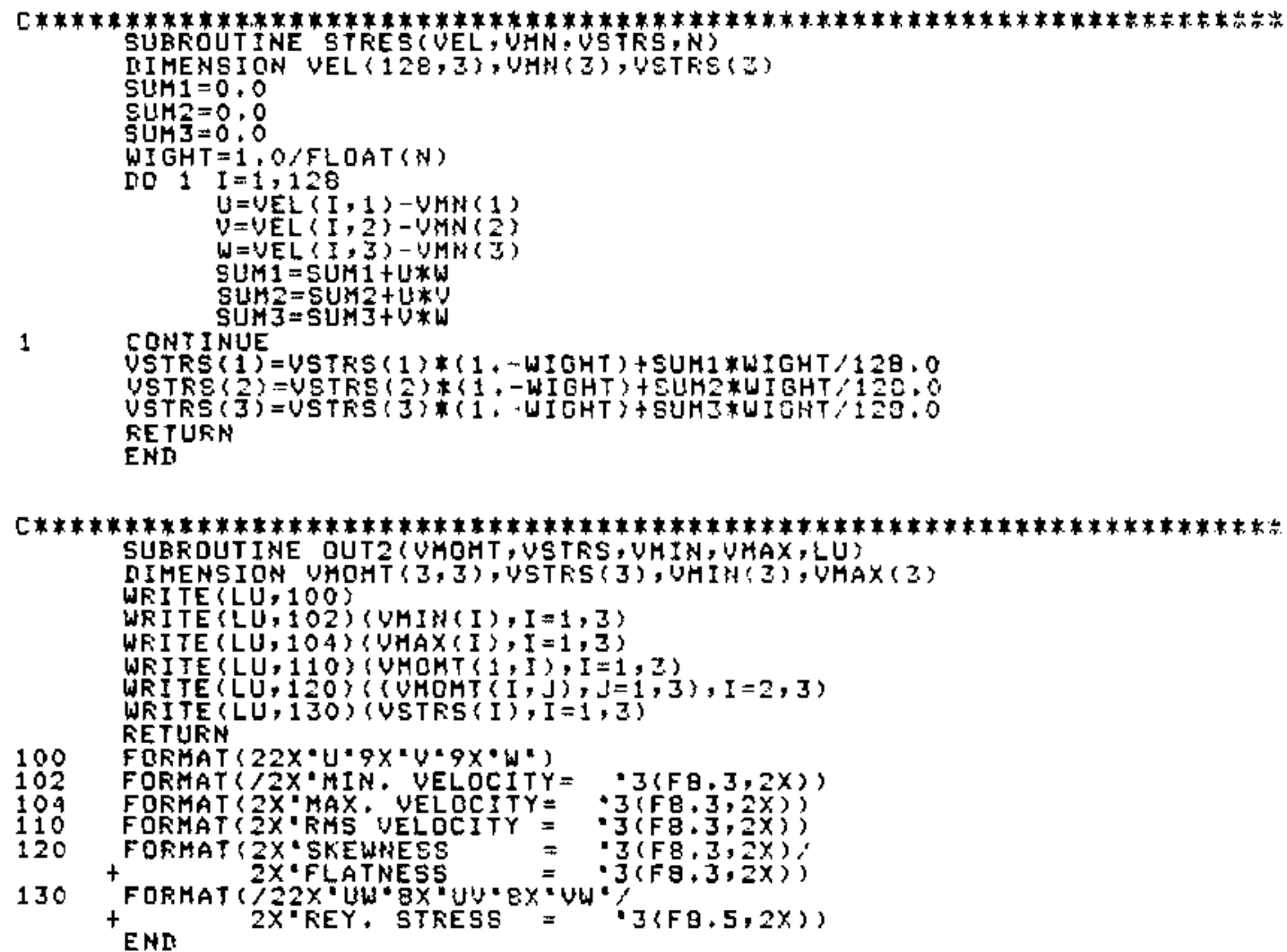




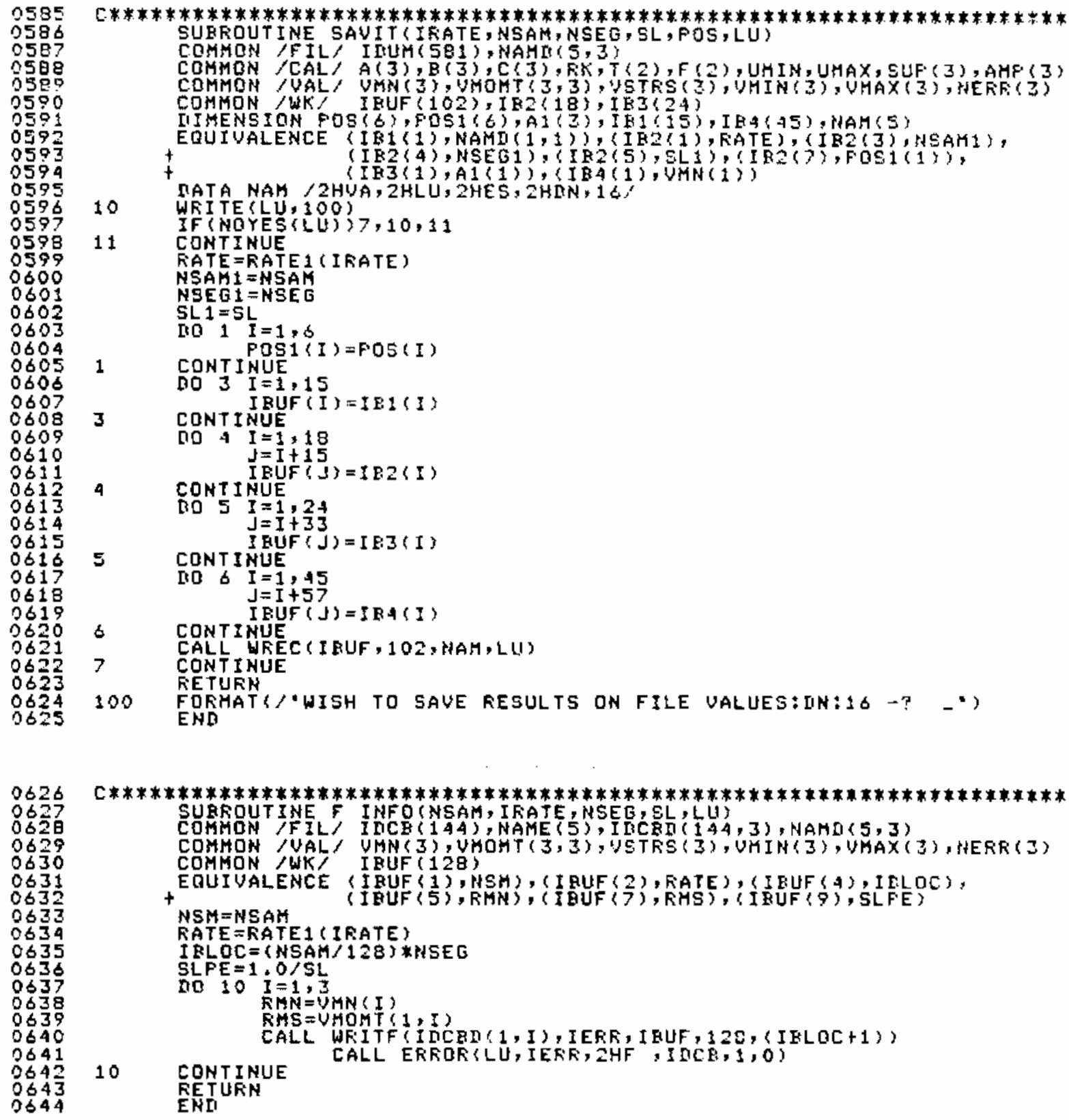




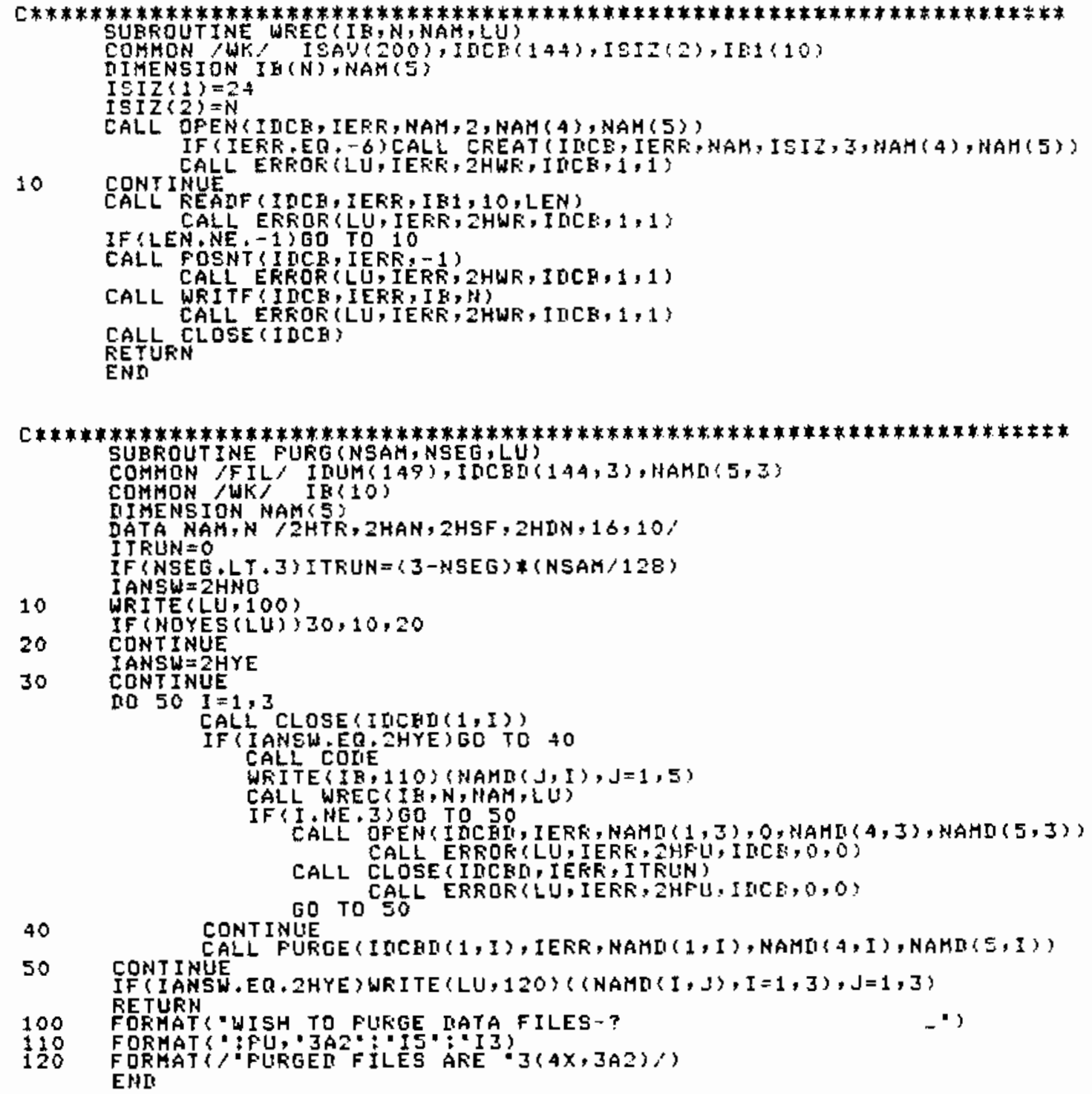




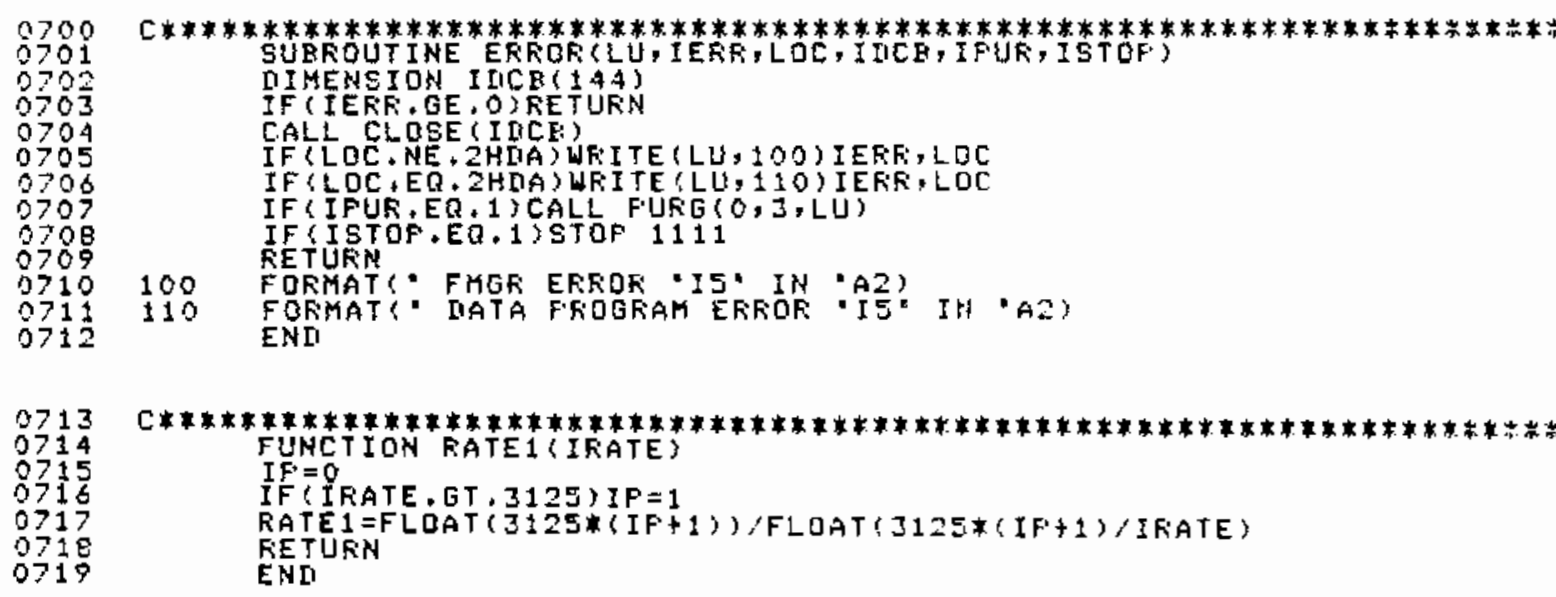


THEE 0001 FTH!. $11: 50$ IM TRI, 25 OCT, 19:5

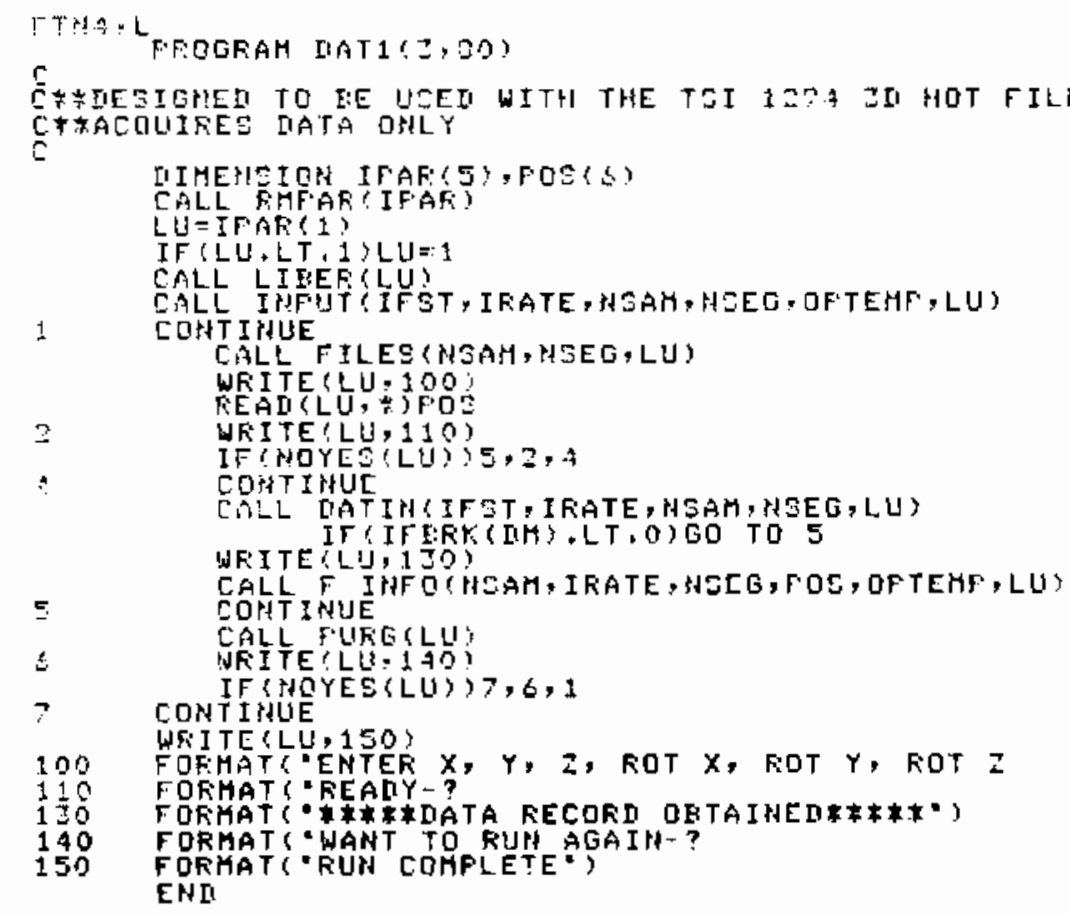




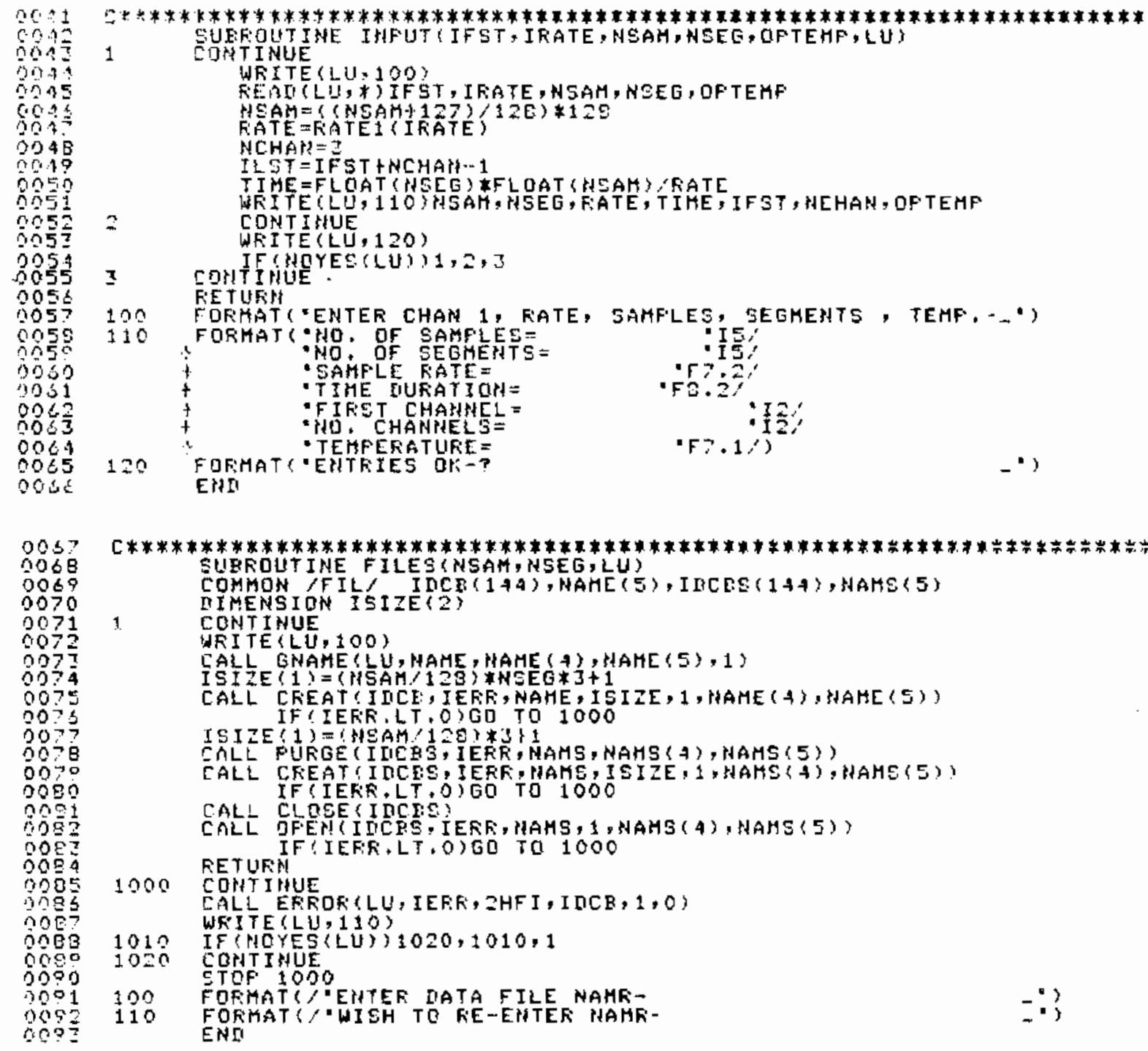



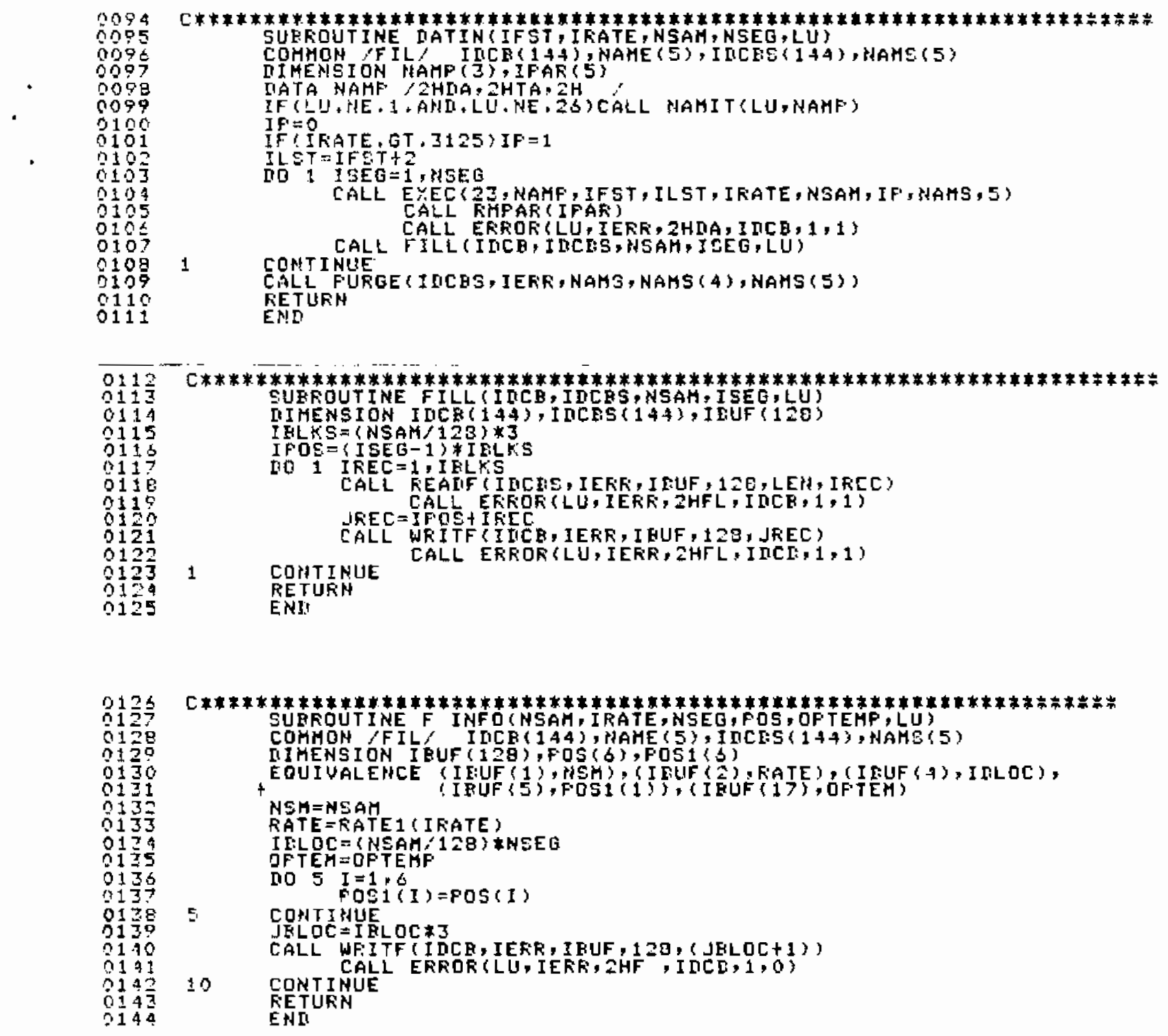


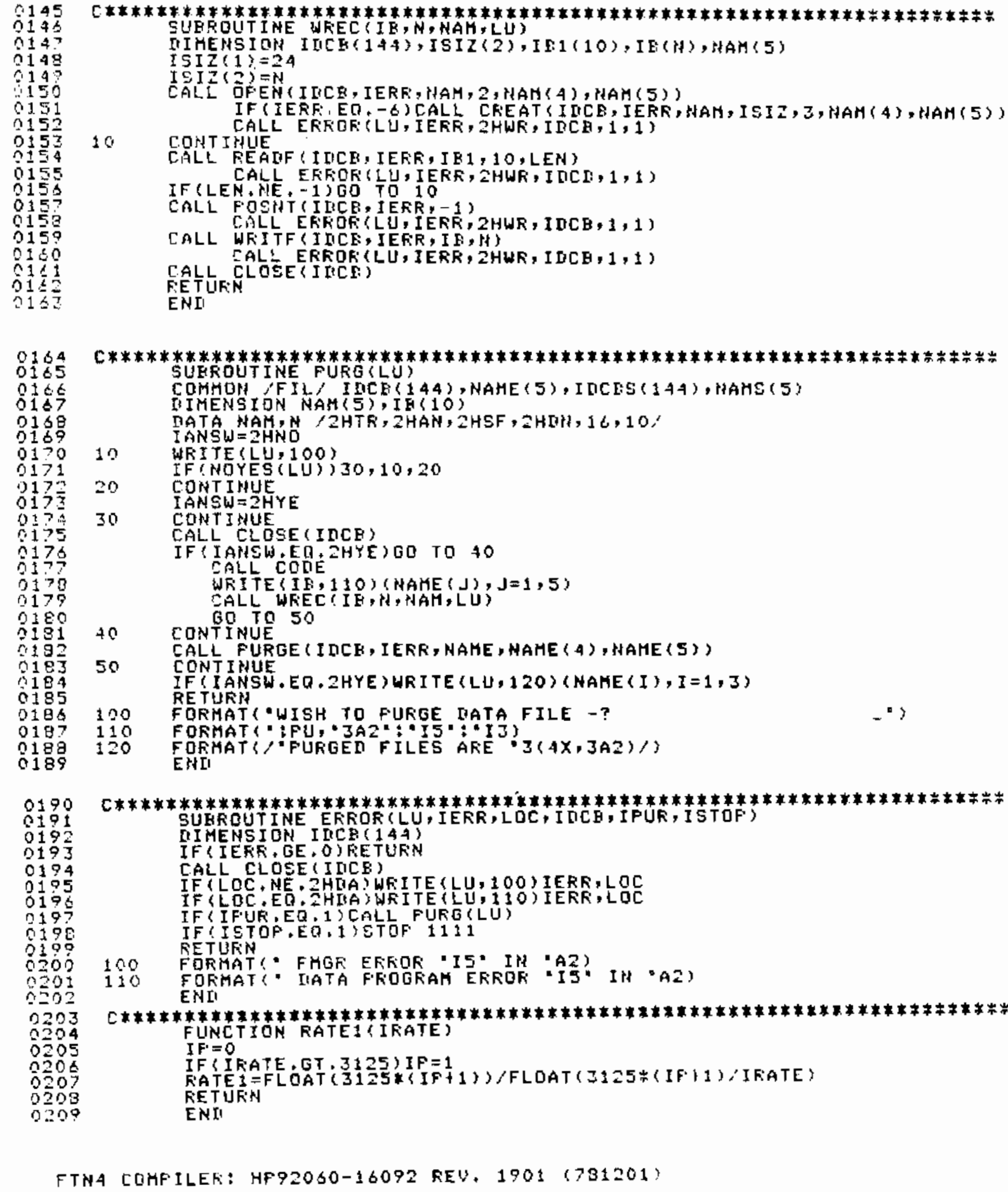




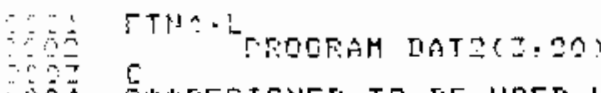

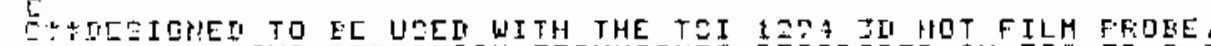

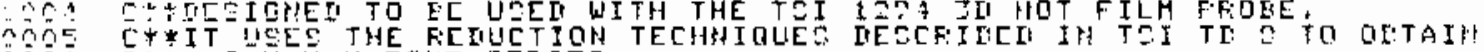

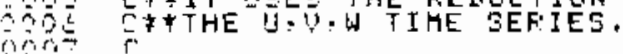

COMHON IUKE IFAFIS?

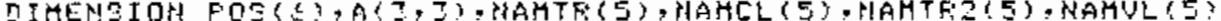

CALL FHF.AF: IF'AF:

LIITIFAR: 1 ?

IF $(L U, L T, 1) L U=1$

EALL LIBEF(LU)

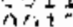

ำ굴

rist

(iin

016

कीज

$\sin =$

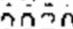

$\therefore \therefore-1$

tring

तिक्ष

तिल

$c t r_{2}=$

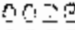

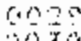

an:

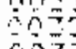

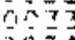

ती

की?

$\neg$

CALL IMHAM (TAHTF, HAMCL, HAMTK2, UAMUL, IAXIS, ICR, IFUF: LU)

FALL VELCL (NAHCL, SL,LU?

$\rightarrow \quad$ COHTINUE

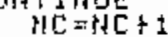

CALL TFFIL (HAMTFi, HAC, IEHI, LU)

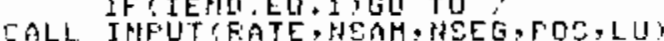

AALL SILESTHSAM, MGEG.ICR, LU

FALL EETLF? FOC,A.IAXIS,LU?

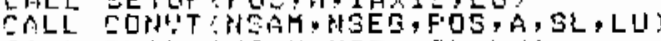

CALL FEIUC INSAH, HSEG, SL, LU:

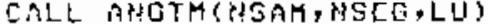

CALL SAYIT (KATE YHSA, NEEG, SL, FDS, HAMUL, LU

CAL FA I ITOR (PSAM, RATE, NGEG, SL, LU)

CALL TRAHE (NAATFE, IFUR,LU)

IF ( $P U E, P ! E, 0) C A L L$ PURE(LU)

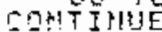

PIC $=M C-1$

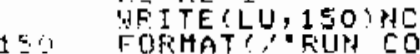

FORHAT?, RUUH COMFLETE O\$ "IS" FU\}S")

ErlT

$\cos 3$

$2 \pi \frac{1}{3}$

ㅁำ응

C1040

0041

$\log 43$

(1)

$\cos 45$

0245

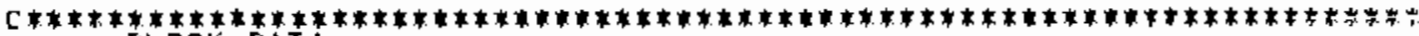

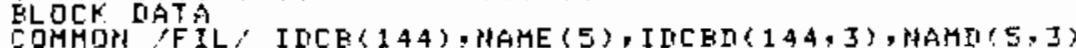

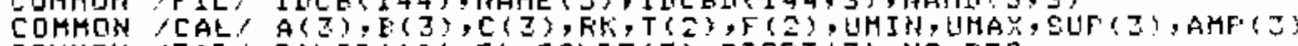

COMHOH, TAF/ CALIP(101,J), CSLFE(3), CICFT,J), NC FTS

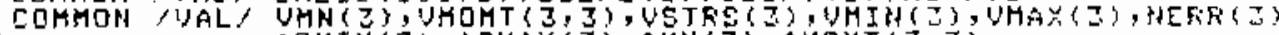

AGHIH (J), AGMAX ( 3 ), AMN (3), AHDHT 3,3 ,

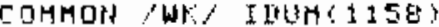

INTA NC FTE, MAME

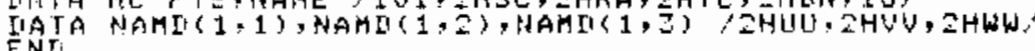




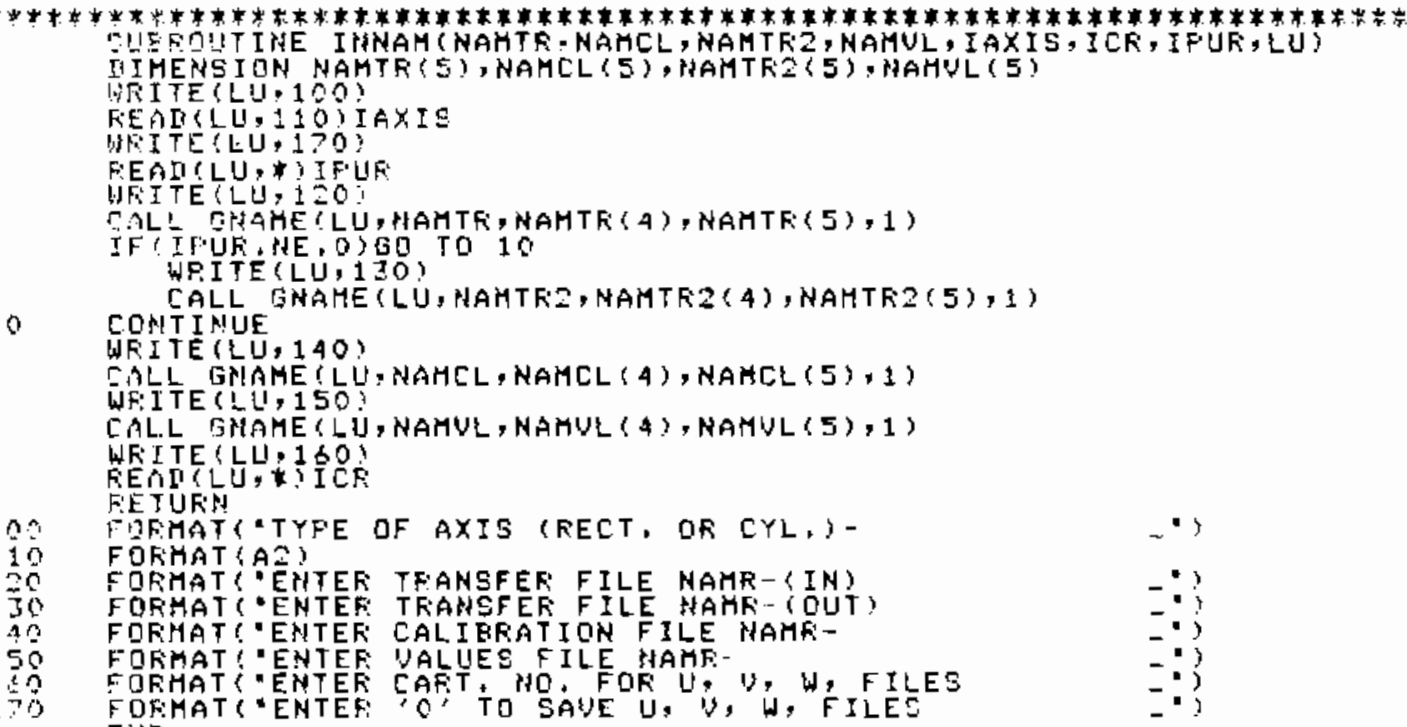

$\operatorname{lng}$

수을

융

कर्ब

6.

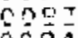

-

ती

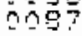

수은

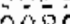

$\operatorname{tin} 1$

$\sin 2$

भ०षि

isis

2095

ris:

$35 \%$

ninte

牙穴的

8100

101

는

ज.

$\therefore 0$

$\therefore 9$

0,107

310

ㄴํㄴ

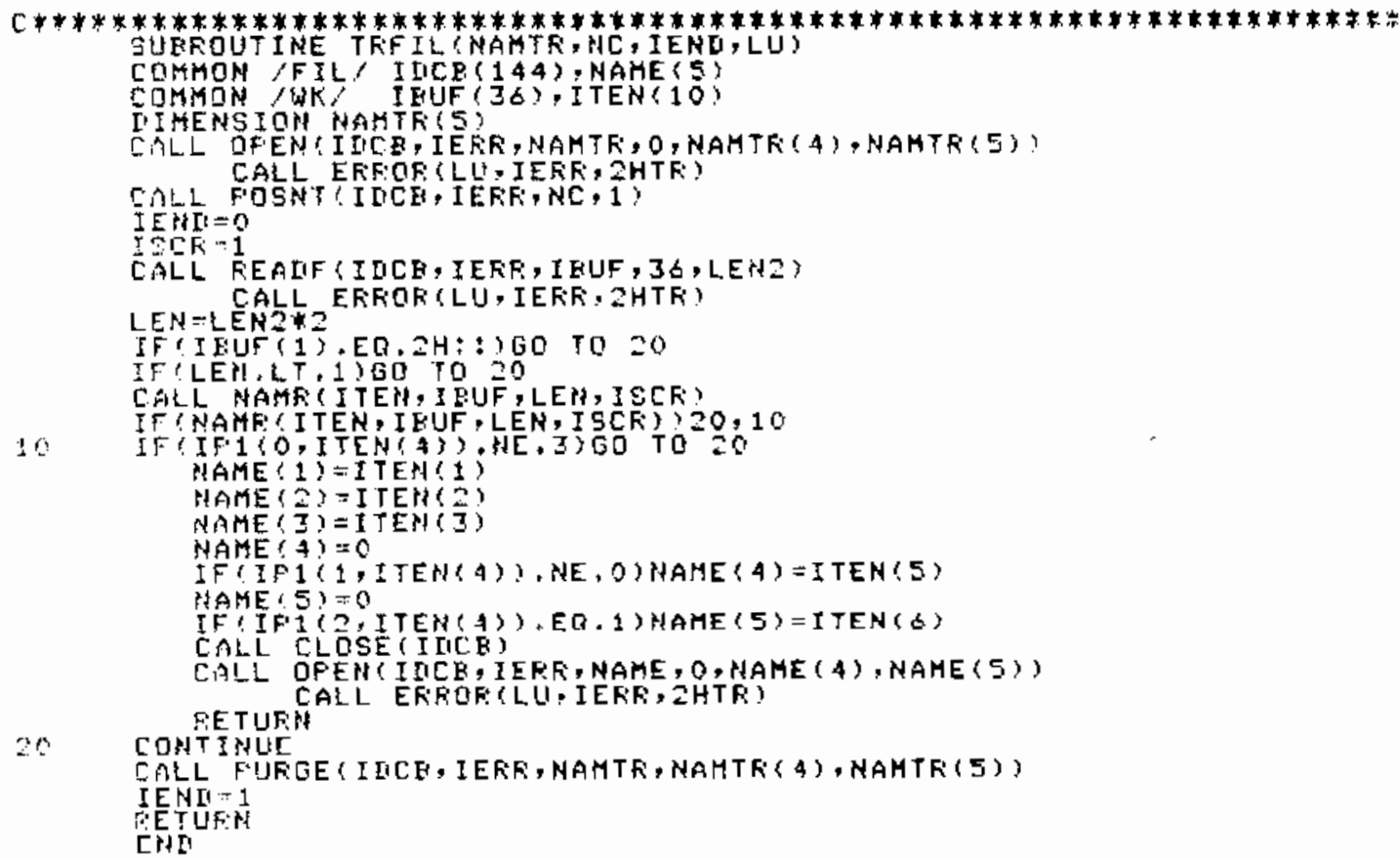




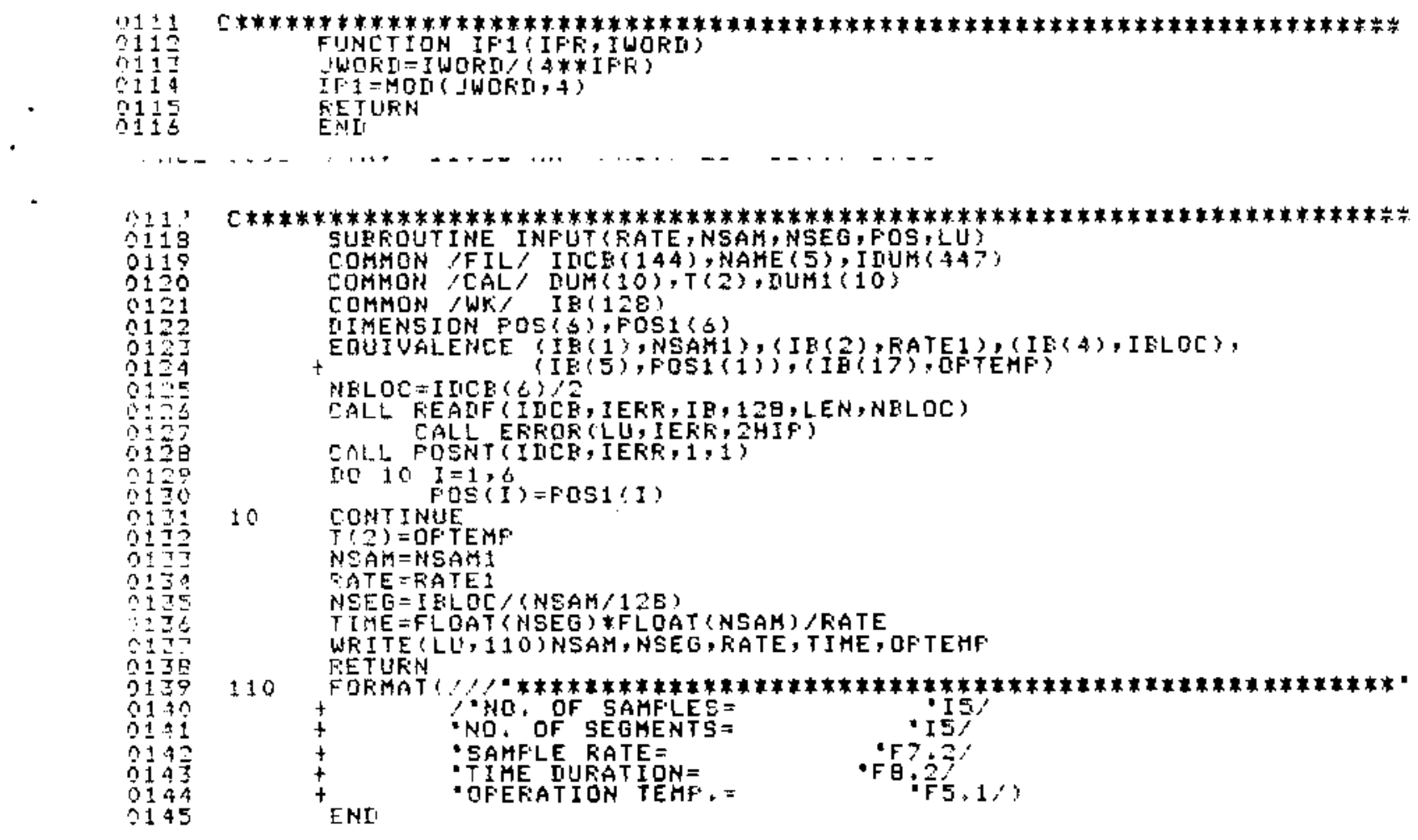




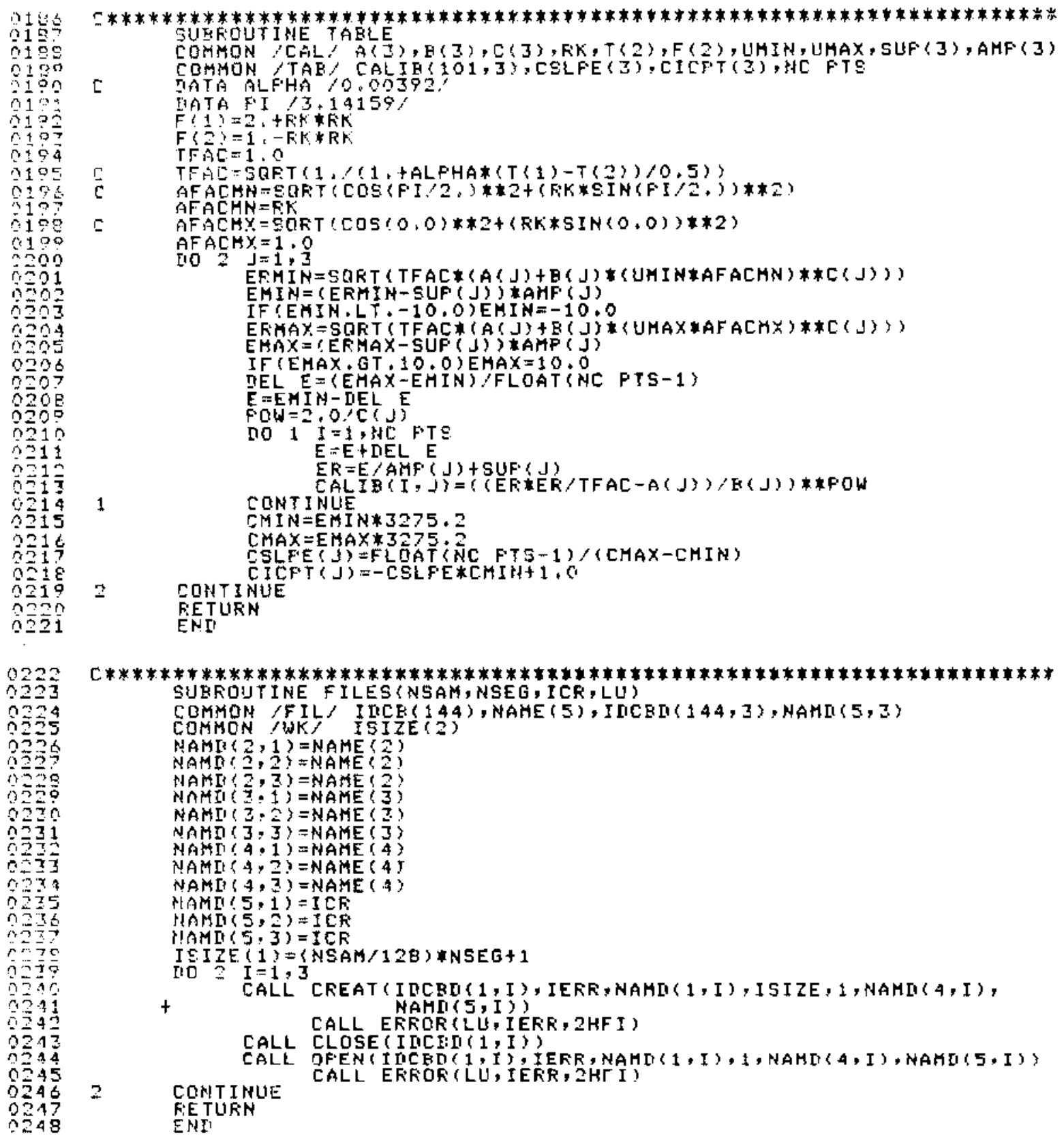


CWCALCULATES THE IISECTIOH COSIHE TEHSOR * $C(3, x)$. FOF THE COORDINATE

C TFANEFOSMATION FFOOH $12943 \mathrm{~T}$ FROPES SENSOR COORHIHATES TO THOSE OF THC DESIREI TUNAEL COORIINATES 'IAYIS'=2HRE FDR RECTANGULAF: SYSTEM, IAYIS: = 2HCY FBR CYLINTERICAL SYSTEM

FDE $(1 ; 3: 3$ ? ARE THE LOCATIONS DF THE FROAE IN THE TUHNEL COORDINATES Y. Y \& $Z$ REQFECTIYELY. WHEN A CONUERSIOH IS MAITE FROM RECTAHGULAF: TO CYLINERICAL COOSIINATES. X REMAINS THE SAME AND FOS (233) ARE CHAHGE FFOM THE INFLIEI Y, Z VALUES TO F, THETA UALUES

FOF THE CYLINIERICAL SYSTEM, WHEN LOKIHG JOWM $(+T 0=)$ THE FOSITIUE

C POXISTHE THETA COMFONEHT IS POSITIVE INT THE COUNTERCLOCKWISE SEHEE.

C FEOTE SUFFORT COOROINATES FFOM AN INITIAL ALIGNMENT WITH THE TUHWEL

C CODKIIIHATES RESFECTIVELY. TRE ROTATIONAL SEQLUENC MUST WE IN THE DRTIER

C: AEDUT $Z$, THEN Y. THEN $X$ SINCE FROEE CDORIINATES WILL HO LONGER FE ALIGHEI

W ITH TUNAEL COORIIHATES AFTER THE FIEST ROTATION. THE SENSE OF THE

C ROTAYIOH IS: LOOKING IOWN Y TO- THE FOSITIUE AXIS OF THE FROTE

CW IIIRECTIOH RESLLTS IM A FOEITIUE AHGLE.

COMHON ,WK $A(3,3), B(3,3)$

IIMENSION FOS

INTA FIIT, 14150,

CONSTFI/1EO.

$\bar{c}$

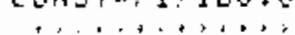

RET $X=0,0 * C O H E T$

FOT YOY $=35+26 * C O N S T$

ROT $Z=-45, O * C O M S T$

CALL TFXYZXA,ROT X,ROT Y,FOT Z

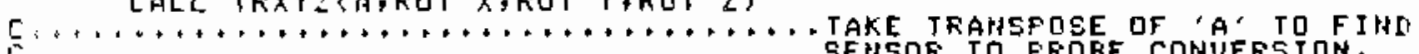

INO $20 \quad I=1,2$ SEHSOR TO FROEE CONVERSION.

10 CONTTHEE

$J=I+1,3$

SAUE $=A(I, J)$

$A(I, J)=A(J, I)$

20 CONTINUE

$A(J, I)=C A$

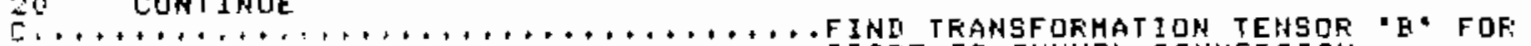

ROT $Y=F O S(4) * C O N S T$

FROEE TO TUHAEL CONUERSIOH.

ROT $Y=P O S(5)$ ECANST

ROT $Z=F O S(b) \star C O N S T$

CALL TFXYZ (E,ROT X,ROT Y,KOT Z)

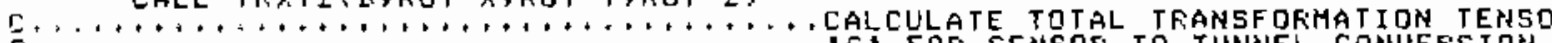

CALL THULT $(A, B, C)$

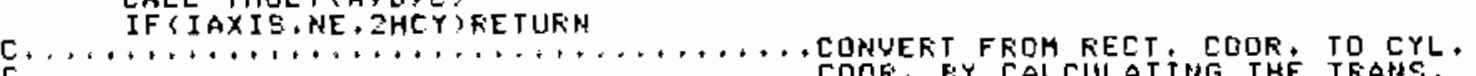

$\frac{C}{c}$

COOF. EY CALCULATIMG THE TRAHS.

TENSOKF A' FOF THE ROTATION ABOUT 


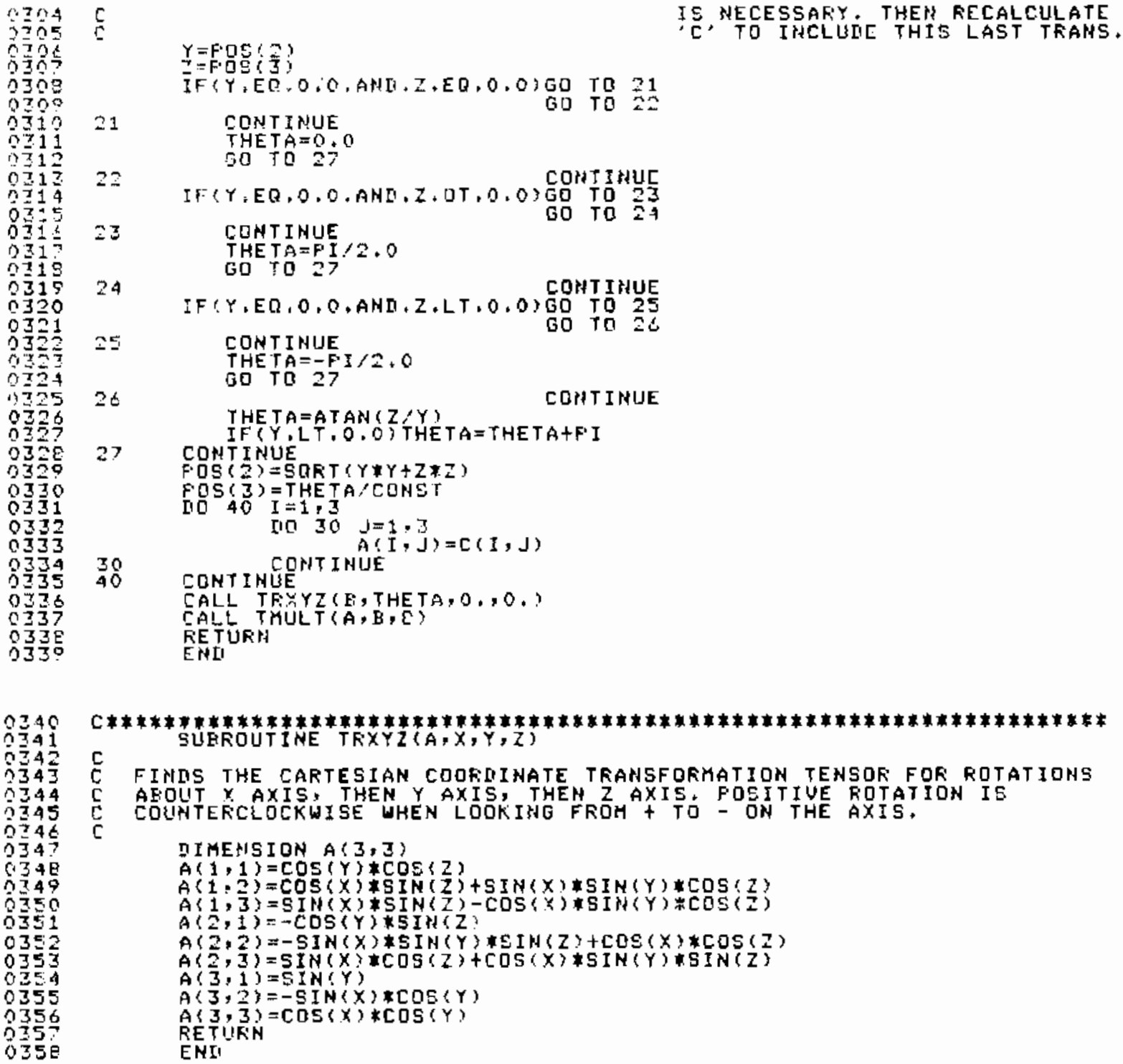




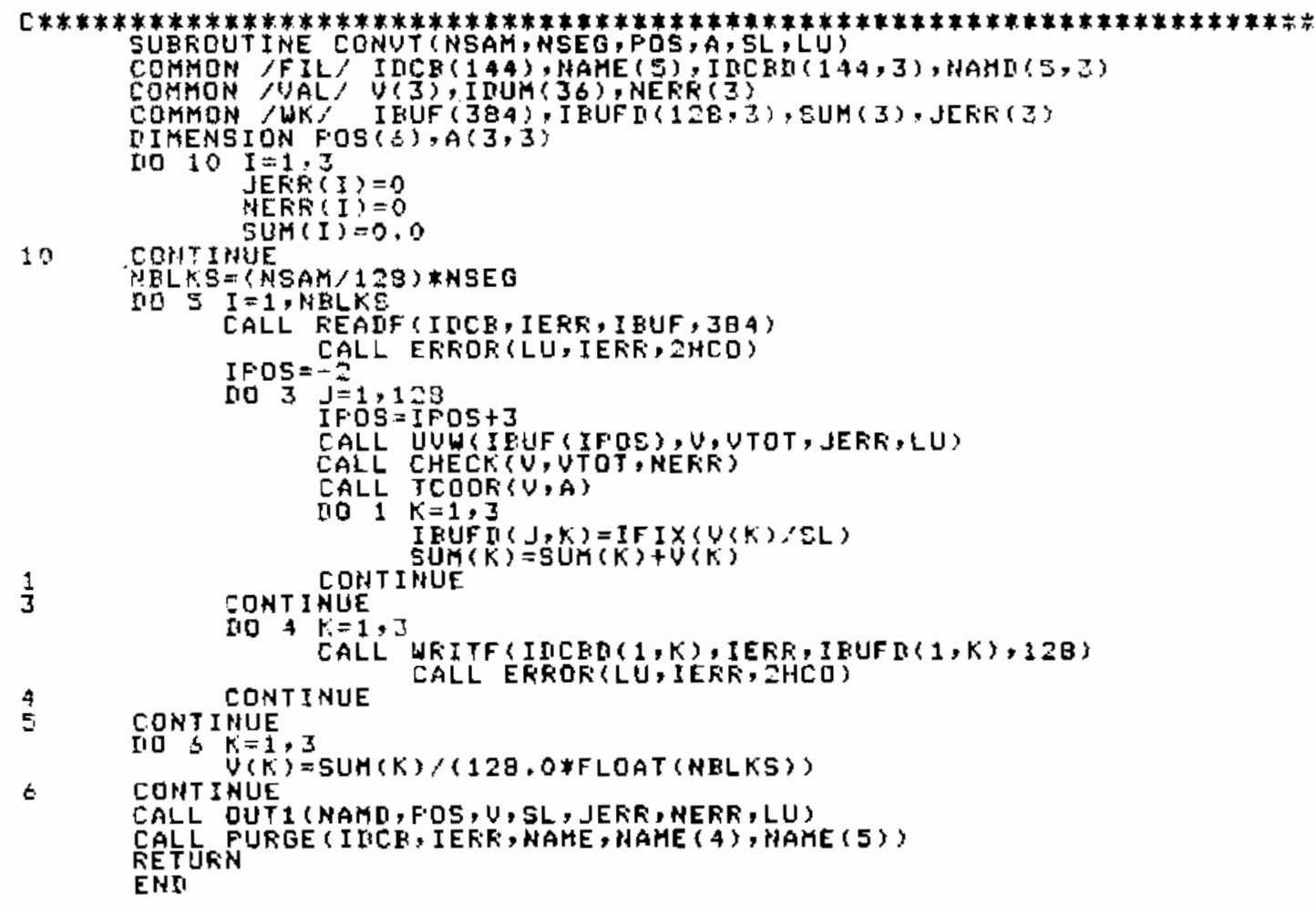




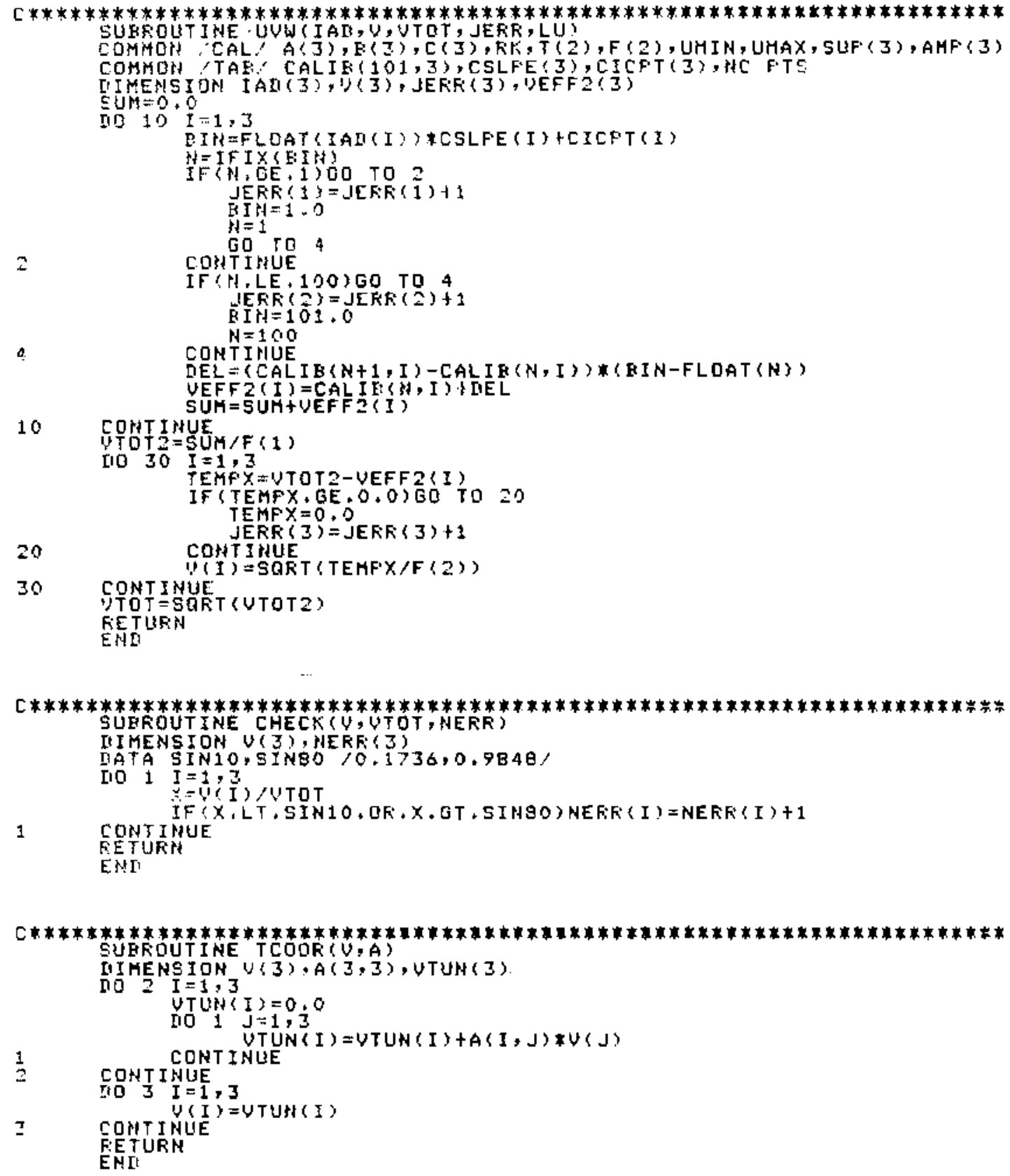




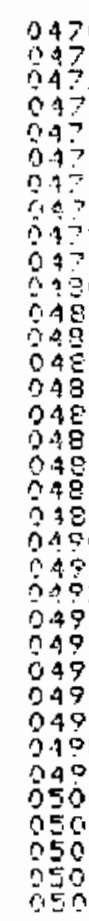

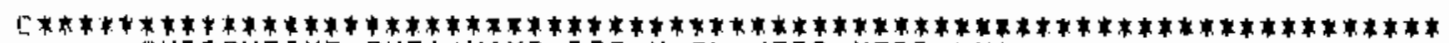

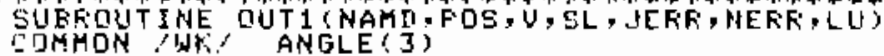

IIIMENSION HAHI $(5,3), F Q S(6), V(3), J E R K(3), N E R F(3)$

WFITE 1 I, 100 ?

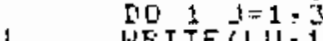

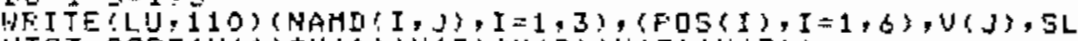

VTOT=SQRT (Uर1)

WRITE $(L U, 120)$ UTOT

ICI $\mathrm{I}=1,3$

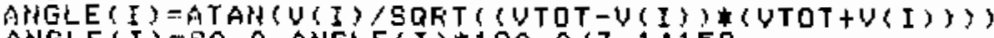

3 CONTINUE

WF: IE (

IF JEFR $(1\}$. NE , O) WRITE $\{L U, 140 ;$ JERE $(1)$

IF ( JERK $(2)$, HE, O) WR I TE (LU, 145) JERR $(2)$

IF IEF:R (3), NE, O WRITE (LU, 150\} JERK $\{3$ )

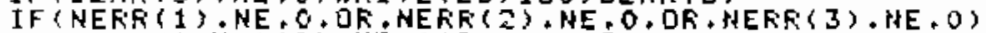

+ WRITE (LU, 160 ) (NERE $\{I\}, I=1 ; 3$ )

100 FETURN

FOFHAT: FILE LINEAF FOSITION

$+$

110

$+7$

UEL, CQUHERSIDN ? NAHE

FORMAT ( $\left.3 A 2,5 X, 6(F, 2), 4 X, F, \frac{7}{2}, 3 X, G \pm 1,3\right)$

130 FOKHAT ( HEAH TOTAL UELOCITY = F T 1 )

$F$
$t$

140

150

EQ:I:FROH

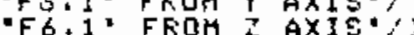

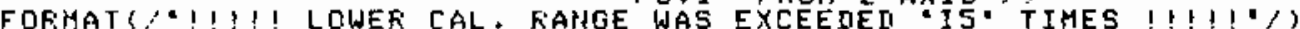

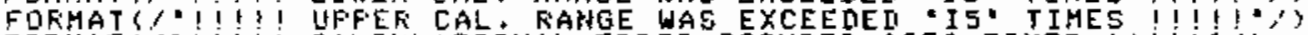

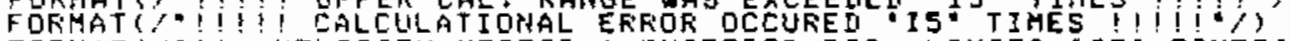

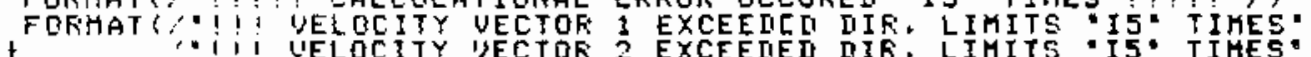

$+$

ENTI

$\because$ I UELOCITY VECTOK

EXCEELIEI IIIR. LIHITS IS. TIMES・) 


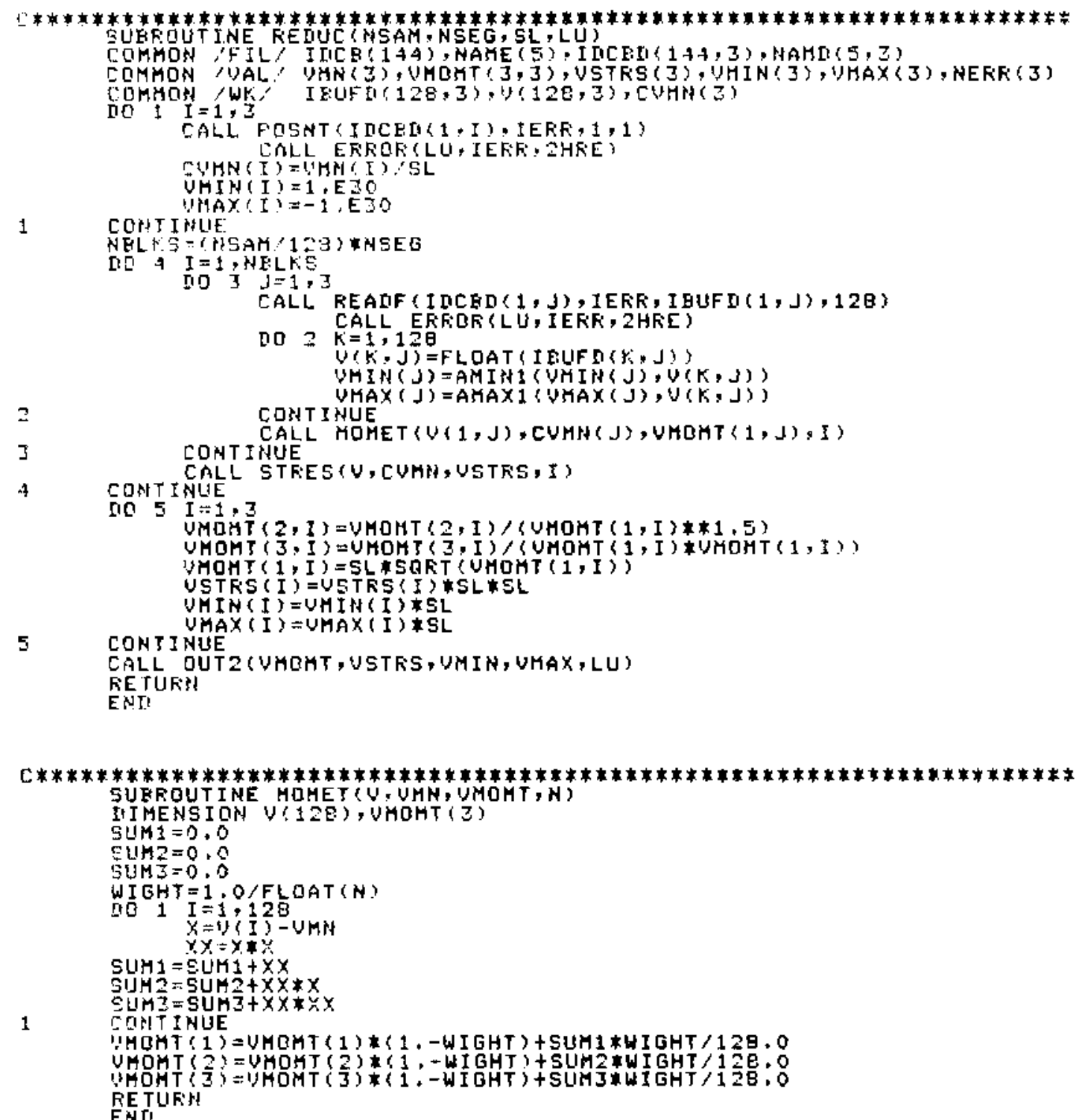


C SUBROUTINE OUT3 (UMDMT, USTRS, UMIN, UMAX,LU) IIENSION UMOHT $(3,3)$, USTRS $(3)$, UNIN $(3), U M A X(3)$ NTITE $T$ LU, 100$)$

WFITE $(L U, 102)(U H I N(I), I=1,3\}$

WEITE (LU, 104 ) (UMAX (I), I=1,3)

WF: ITE (LU, 110) (UMOHT $(1, I), I=1,3)$

WRITE (LU, 120$)(($ UHOHT $(1, J), J=1,3), I=2,3)$ WRITE (LU, 130 ) (VSTRS (I), $1=1,3$ )

FETURN

100

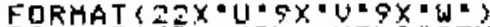

FOKMAT /

FOFHAT ( $2 X^{*} M A X$, VELOCIYY $=3(F 8,3,2 X)$

FOFMAT ( $2 X^{\circ}$.MAS VELOCITY $=3(F \mathrm{~B}, 3,2 X)$

FORHAT (2X"SKEWHESS $=3(F B, 3,2 X)$

130

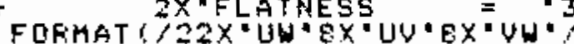

tENO

2X.REY. STRESS $=3(F g, 5,2 X)$

000

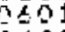

0.002

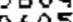

0.06

isc

050

C. 610

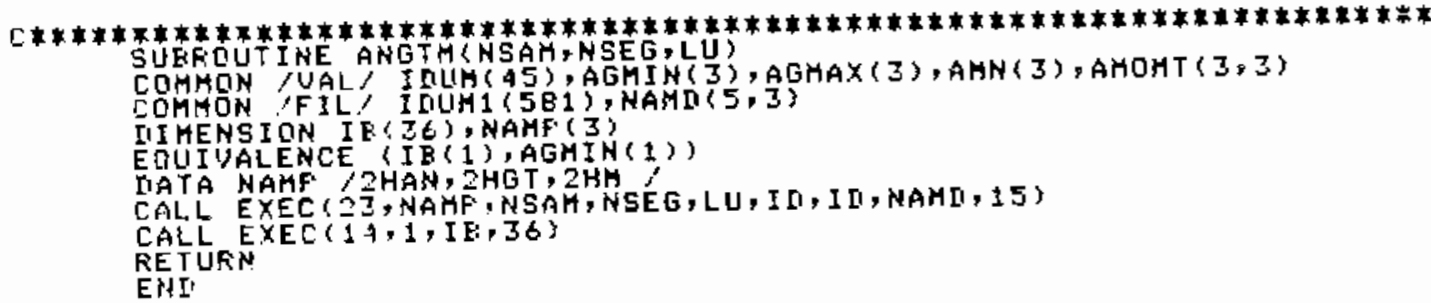




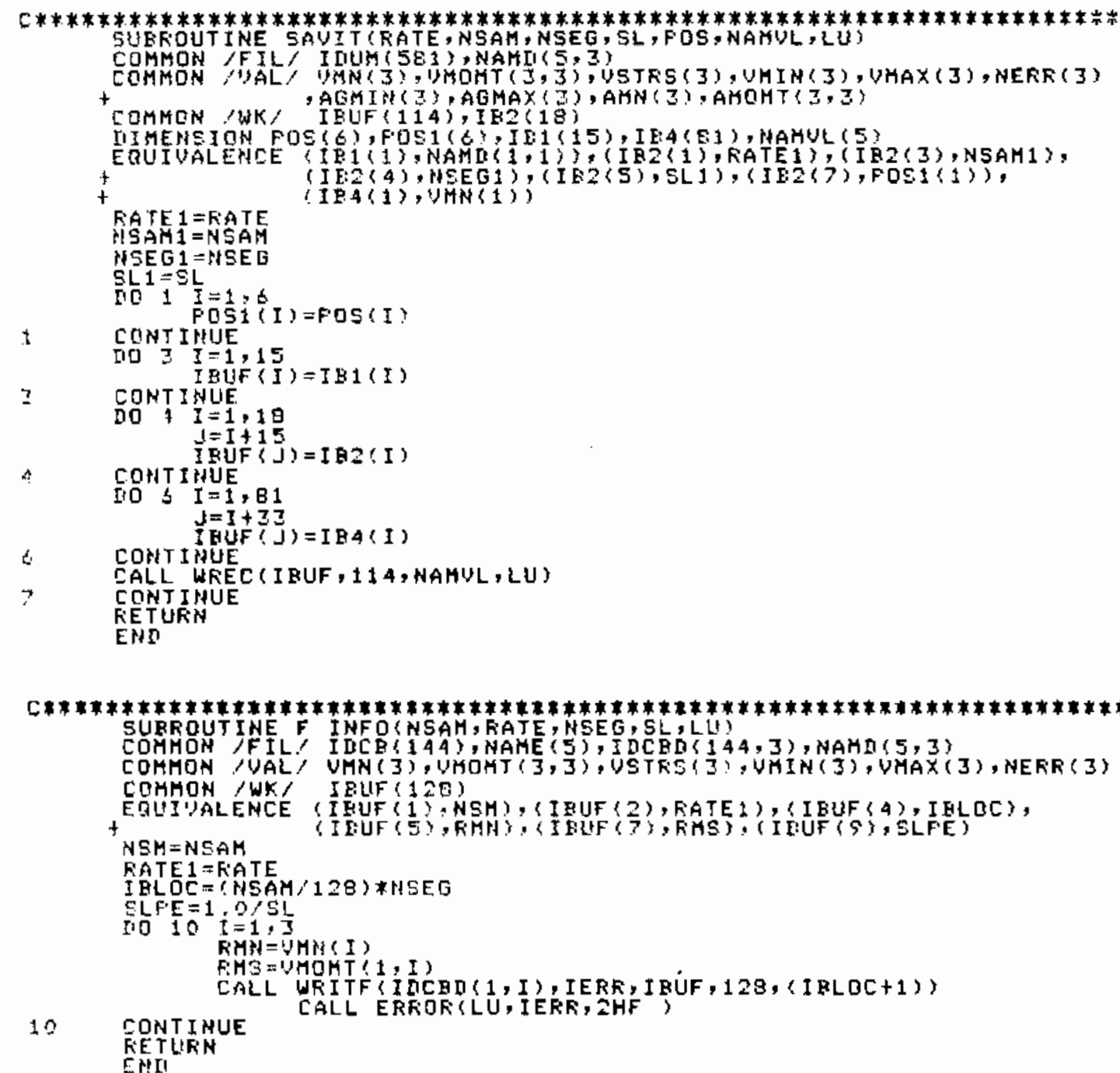



SUBROUTINE TRANS (NAMTR2, IFUR,LU\}

กㄱำ

070

0706

0700

$0 ? 10$

0711

0713

0714

2715

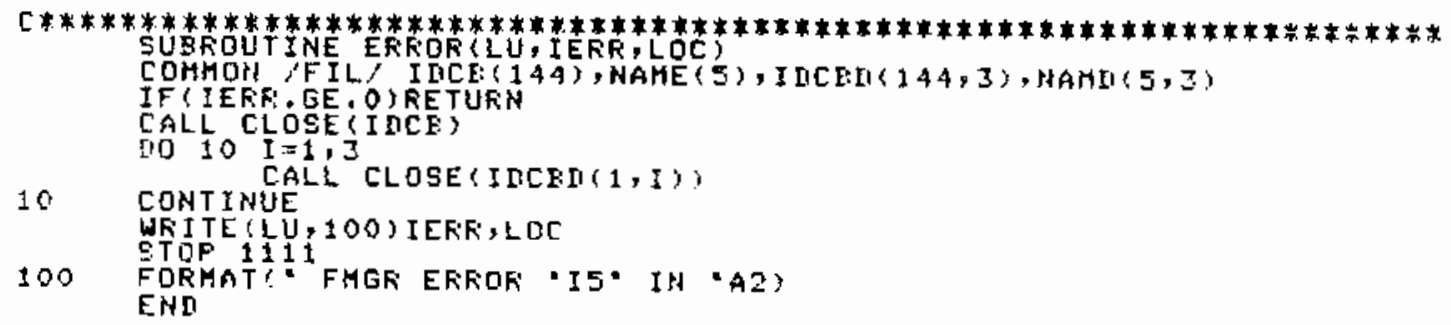




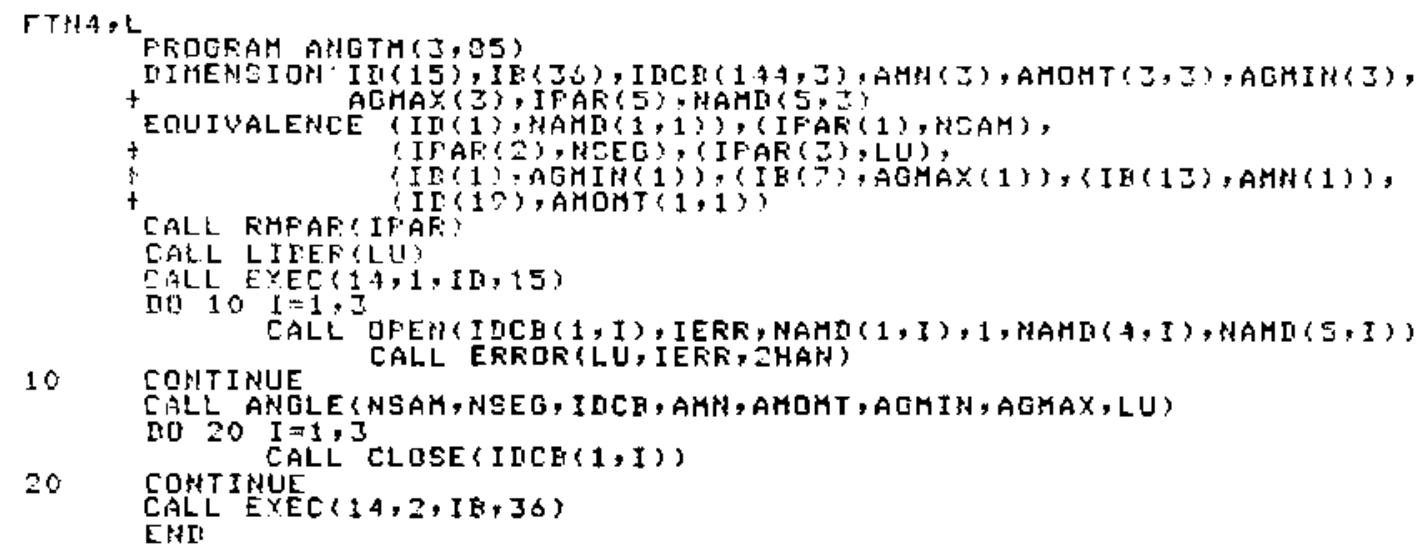




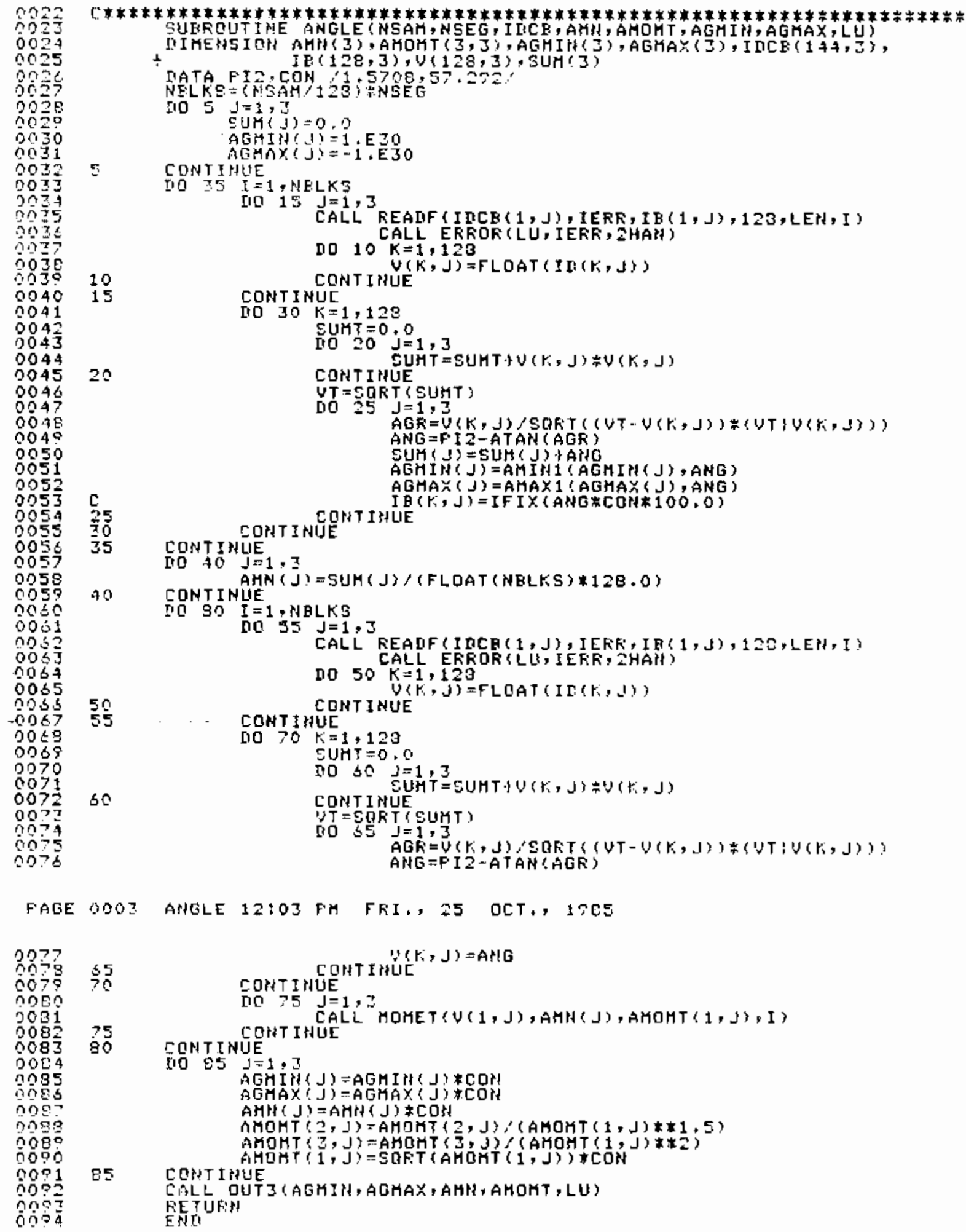



SUEROUT INE MOHET (V, UHN, UHOHT,N) IIMENSIOH $V(12 B)$, VHOMT ( 3$)$ SUM1 $=0.0$

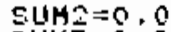

SƯ $13=0.0$

WIGHT $=1.0 / F L O A T(N)$

IIO 1 I $=1,123$ $x=U(I)-U M N$

0102

0103

010

0106

0107

0108

0109

8119

$011 \frac{1}{12}$

$01 \frac{1}{3}$

EUH $=5$ in $x+x$

SUH $=S U M 2+x \times+x$

1 CDNTINUE

VHOMT $(1)=$ VHOKT $(1) *(1,-W I G H T)+5$ UN1*WIGHT 1229,0

UMOKT ( 2$)=U M O N T(2) \$(1,-W I G H T)+S U M 2 \neq W 1$ GHT $/ 120.0$

VHOHT $(3)=$ UNOHT $(3) *(1,-W I G H T\}+5 U H 3 * U$ I GHT/128.0

RETURH

0114

0115

0116

0117

$011 \mathrm{~B}$

0119

015

0125

ก1 33

$01 \frac{1}{2}$

012

$01 \frac{2}{3}$

$0 \pm 28$

0130

0133

0133

0134

0136

0137

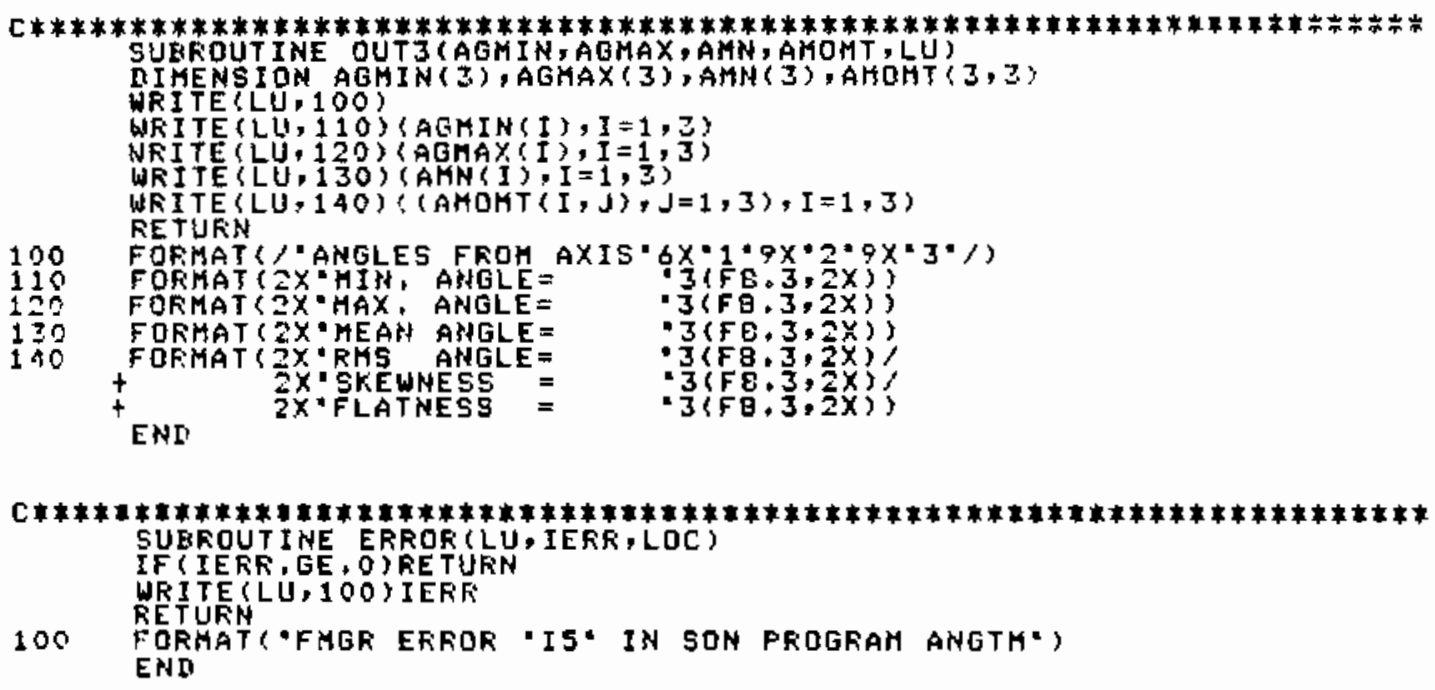




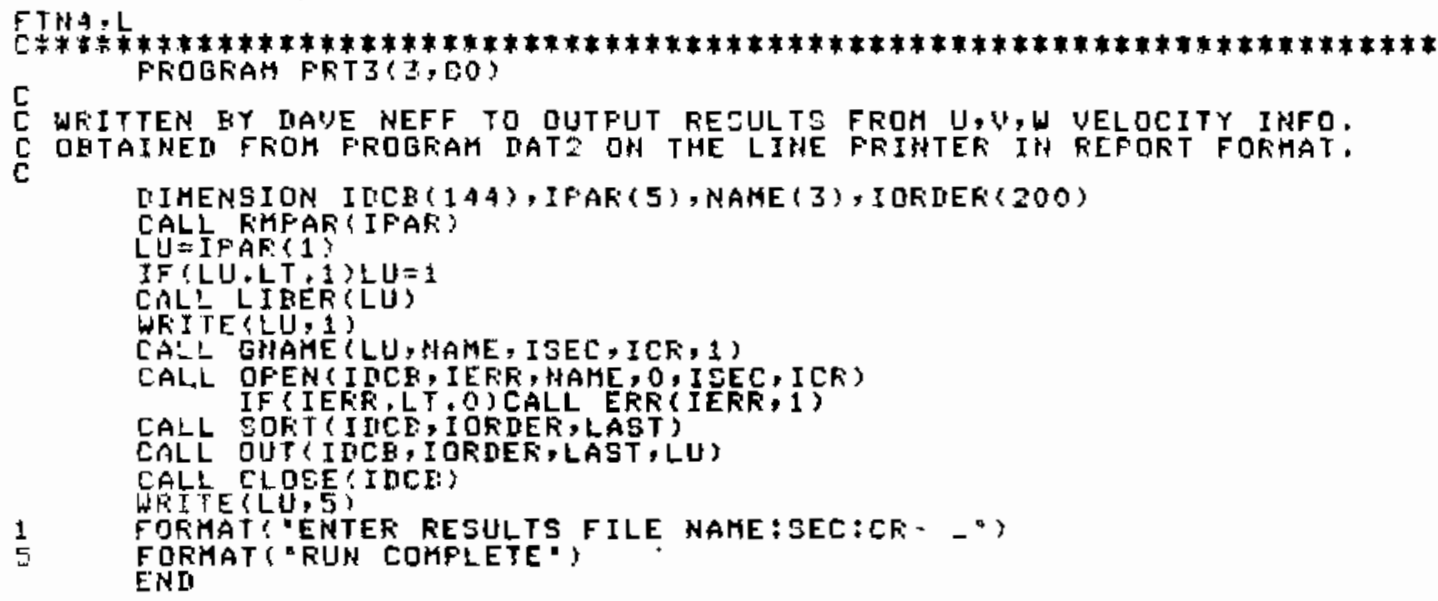




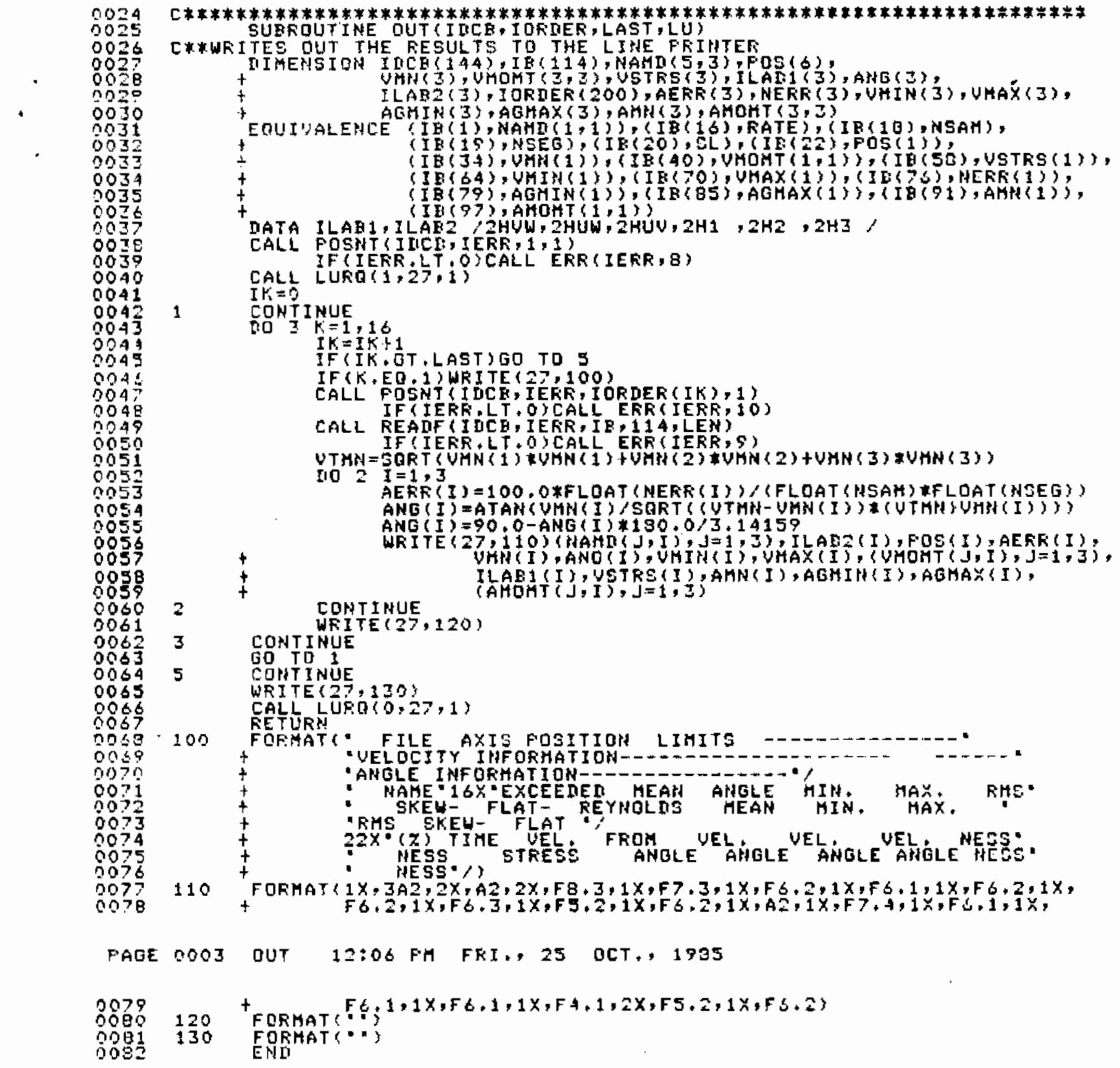




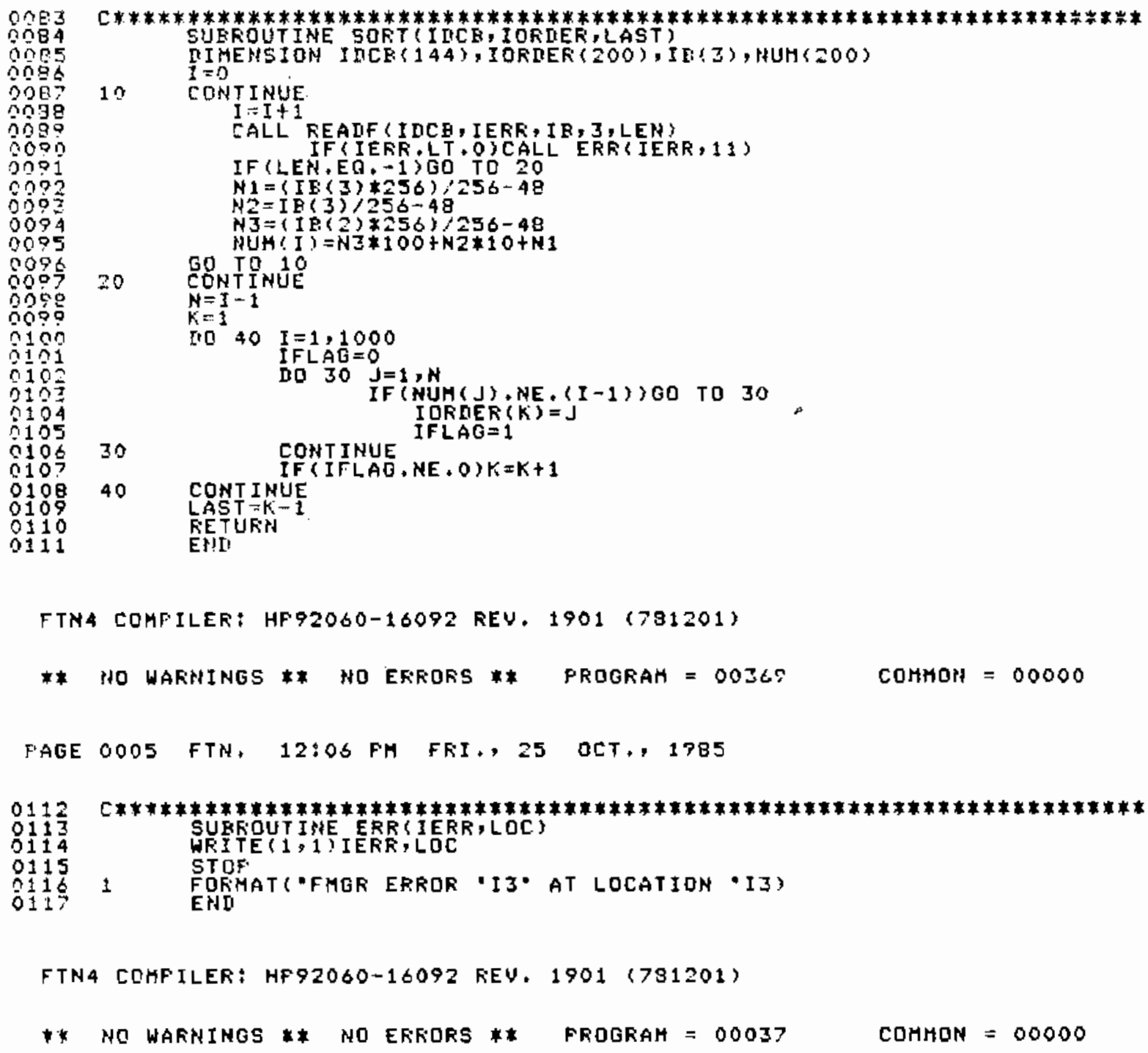




\section{DISTRIBUTION}

No. of

Copies

\section{OFFSITE}

C. I. Aspliden

Battelle Memorial Institute

Washington Office

2030 M Street, NW

Washington, DC 20036

J. Cadogan

U.S. Oepartment of Energy

Wind/Ocean Technologies Division

1000 Independence Avenue

Forrestal Building, Room $5 \mathrm{HO} 48$

Washington, DC 20585

G. P. Tennyson

U.S. Department of Energy

Albuquerque Operations Office

P.0. Box 5400

Albuquerque, NM 87110

30 DOE Technical Information Center

R. M. Sundar

Embry-Riddle Aeronautical University

3200 N. Willow Creek Road

Prescott, AZ 86301

R. B. Schlueter

Department of Electrical Engineering

Michigan State University

East Lansing, M1 48824

D. Spera

NASA/Lewis Research Center

21000 Brookpark Road

Cleveland, $\mathrm{OH} 44135$
No. of

Copies

P. M. Moretti

Oklahoma State University

Mechanical and Aerospace

Engineering

Engineering North 218

Stillwater, OK 74074

J. P. Sullivan

Aeronautics \& Astronautics

Grissom Hall

Purdue University

W. Lafayette, IN 47907

P. Klimas

Sandia National Laboratories

Division 6225

Albuquerque, NM 87185

D. C. Reda

Sandia National Laboratories

Division 6225

Albuquerque, NM 87185

R. W. Thresher

Solar Energy Research Institute

1617 Cole Boulevard

Golden, CO 80401

S. M. Chan

Systems Control, Inc.

1801 Page Mill Road

P.0. Box 10025

Palo Alto, CA 94303

R. L. George

TERRA Sciences, Inc.

7555 W. 10th Avenue

Lakewood, CO 80214 
No. of

Copies

R. H. Kirchhoff

Department of Mechanica] Engineering

University of Massachusetts

Amherst, MA 01003

V. A. Vachon

P.0. Box 149

Manchester, MA 01944

P. Veers

2700 Del Medio Court $\# 304$

Mountain View, CA 94040

\section{ONSITE}

DOE Richland Operations office

J. J. Sutey/O. R. Segna
No. of

Copies

\section{Pacific Northwest Laboratory}

J. C. Barnard

J. R. Conne11 (10)

D. W. Dragnich

C. E. Elderkin

D. L. Elljott

M. J. Graham

J. M. Hales

P. C. Hays

V. R. Morris

E. L. Owczarski (5)

D. C. Powell

J. A. Stott lemyre

T. K. Thompson

$L$. L. Hende 11

R. E. Hildung

Technical Information Files (5)

Publishing Coordination (2) 